UNIVERSIDADE DE SÃO PAULO

FACULDADE DE FILOSOFIA, LETRAS E CIÊNCIAS HUMANAS

DEPARTAMENTO DE GEOGRAFIA

PROGRAMA DE PÓS-GRADUAÇÃO EM GEOGRAFIA FÍSICA

\title{
ANÁLISE SÓCIO-AMBIENTAL DA BACIA DO RIO BIGUAÇU-SC: SUBSÍDIOS AO PLANEJAMENTO E ORDENAMENTO TERRITORIAL
}

Vicente Rocha Silva

São Paulo - SP

2007 
UNIVERSIDADE DE SÃO PAULO

FACULDADE DE FILOSOFIA, LETRAS E CIÊNCIAS HUMANAS

DEPARTAMENTO DE GEOGRAFIA

PROGRAMA DE PÓS-GRADUAÇÃO EM GEOGRAFIA FÍSICA

\section{ANÁLISE SÓCIO-AMBIENTAL DA BACIA DO RIO BIGUAÇU-SC: SUBSÍDIOS AO PLANEJAMENTO E ORDENAMENTO TERRITORIAL}

\section{Vicente Rocha Silva}

Tese apresentada ao Programa de Pós- Graduação em Geografia Física, do Departamento de Geografia da Faculdade de Filosofia, Letras e Ciências Humanas da Universidade de São Paulo, para obtenção do título de Doutor em Geografia Física.

Orientador: Prof ${ }^{\circ}$. Dr. Jurandyr Luciano Sanches Ross 


\section{AGRADECIMENTOS}

A conclusão desta tese contou com a ajuda e colaboração de diversas pessoas entre professores, técnicos, amigos e colegas do curso de pós-graduação em geografia. Meus sinceros agradecimentos.

Ao meu orientador Prof. Dr. Jurandyr Luciano Sanches Ross, pelos ensinamentos, competência e a amizade durante a realização da pesquisa.

Aos meus pais Adolfo e Enérea, pelo incentivo e ajuda para realizar mais uma etapa de qualificação profissional na geografia.

A Ivanete Nardi, geógrafa e pós-graduanda em Educação, que acompanhou toda a trajetória desse estudo, colaborando desde o início, ajudando na digitação, trabalhos de campo e fotos.

Ao geógrafo e mestre em geografia, Fernando S. Kawakubo, pela amizade e competência dando suporte na área de Sensoriamento Remoto e SIG, para a elaboração dos mapas temáticos.

À amiga Lisangela Kati do Nascimento, socióloga e mestre em geografia, por toda a ajuda, incentivo e apoio logístico durante as viagens para São Paulo.

A Rúbia Gomes Morato, geógrafa e mestre em geografia, pelo apoio, incentivo e amizade iniciada no laboratório de Sensoriamento Remoto do departamento de geografia da FFLCH da USP.

À amiga e colega de pós-graduação na geografia da USP, Andréia Arruda de Oliveira Mosca pelo apoio e incentivo dispensados.

Ao Conselho Nacional de Desenvolvimento Científico e Tecnológico- CNPq, pela concessão da bolsa de estudo.

A Luiza L. Bricalli, geógrafa e mestre em geografia, pela amizade iniciada na pós-graduação do FFLCH da USP.

À amiga Marize Muniz, prof ${ }^{a}$ de geografia em São Paulo, pelo incentivo e apoio.

Ao Prof. Dr. Ailton Luchiari, coordenador do laboratório de Sensoriamento Remoto do departamento de geografia da USP, pela autorização do uso de equipamentos na produção dos mapas.

À Secretaria da Pós-Graduação em Geografia da Faculdade de Filosofia, Letras e Ciências Humanas da USP, em São Paulo, funcionárias: Ana Lúcia Lima Pereira, Jurema Ricci Navarro, Maria Aparecida Brambilla e Rosangela Fidalgo Garcez, pela dedicação e interesse na questão administrativa durante o curso.

Aos técnicos do Digeo/Sul do IBGE, em Florianópolis-SC: Eng. Agrônomo José Marcos Moser pela cessão de material cartográfico, que deram subsídios à pesquisa. Ao Eng. Agrônomo Sérgio H. Shimizu, pelas explicações sobre os solos e legenda do mapa de solos.

Ao geólogo e prof. MSc. da UFSC, João Carlos Gré, por ter acompanhado em trabalho de campo na bacia do rio Biguaçu e pelas fotos. 
À Eng. Agrônoma Rosilda Feltrin da Epagri em Antônio Carlos-SC pela disponibilidade de dados sobre o Plano Municipal de Desenvolvimento Rural Sustentável do município de Antônio Carlos.

Ao Eng. Agrônomo Waldemiro Sudoski da Epagri de Biguaçu-SC, pelos dados e informações fornecidas sobre o setor rural do município de Biguaçu.

A Giorgia Limnios, geógrafa e mestre em geografia, pela elaboração da base cartográfica digital da área de estudo.

Ao Prof. MSc. Leandro R. Vestena, da Universidade do Centro-Oeste-PR pelo envio de material bibliográfico sobre hidrologia.

Às funcionárias Maria Helena Zepelini e Sueni Juraci de Mello dos Santos, da Supervisão de Documentação (SDI) do IBGE, em Florianópolis-SC, pela dedicação e empenho no fornecimento de dados e informações para a pesquisa.

Ao Prof. Dr. Fabiano Antônio de Oliveira, professor da Univille em Joinville-SC, pela disponibilidade de cópia de sua pesquisa.

Ao acadêmico de geografia da USP, Jânio Souto, pela elaboração de tabelas e gráficos da pesquisa.

A Rogério Rozolen Alves, acadêmico de geografia da USP, pela elaboração de tabelas da pesquisa.

A Vera Lúcia da Epagri em Florianópolis, pelo fornecimento de dados de clima da Estação de São José-SC.

A Julianna Steffens, acadêmica de geografia da UDESC, em Florianópolis-SC, pela organização de fotos e tabelas no texto final.

À prof ${ }^{a}$ Dr. Magaly Mendonça da UFSC, pelo fornecimento de cópia de sua tese.

Aos moradores da cidade de Biguaçu, Sr. Manoel Bento da Silva e Sr. Nelson João Adriano pela colaboração e dedicação na realização de atividades nos trabalhos de campo no rio Biguaçu.

Ao Sr. Bertolino José Weber, morador da localidade de Canudos, pelas valiosas informações sobre o município de Antônio Carlos.

Ao Sr. Anselmo Manes do escritório local da Casan em Antônio Carlos, pelas informações prestadas sobre o abastecimento público de água tratada.

Ao Sr. Edemir Muller Coelho, do escritório local da Casan em Biguaçu, pelas informações fornecidas sobre o abastecimento público de água do município.

Ao Sr. José Nilton Junkes, morador do município de Antônio Carlos, pelas informações e apoio em trabalho de campo.

Às comunidades dos municípios de Antônio Carlos e Biguaçu em Santa Catarina, pela troca de informações e conhecimento sobre a bacia do rio Biguaçu.

À Prof ${ }^{a}$ de português-espanhol, Stela Maris Slaviero, pela revisão do texto e tradução do resumo.

A Weiler Pereira Simões pela disponibilidade de estada em sua residência em São Paulo. 
A Elisabet Corrêa Simões, assistente social, por toda a atenção e carinho nas inúmeras vezes em que fiquei em sua casa, em São Paulo, desde o início do curso em agosto de 2003. Agradeço também, aos seus sobrinhos, Hudson C. Simões, Ataualpa C. Simões e Marco Antônio C. Simões, pela colaboração e apoio logístico. 


\section{SUMÁRIO}

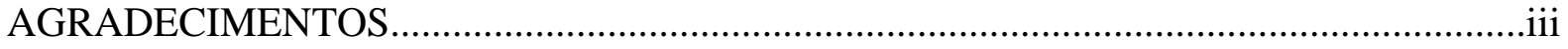

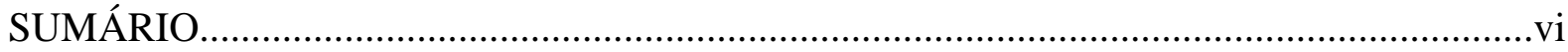

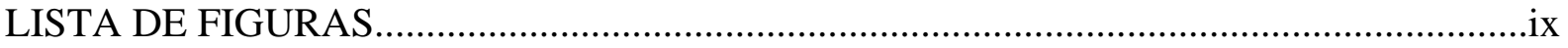

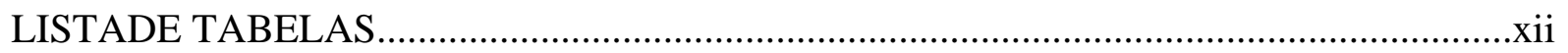

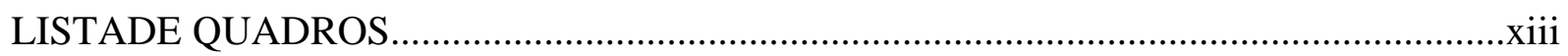

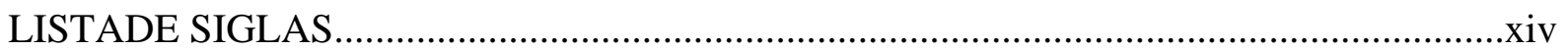

RESUMO

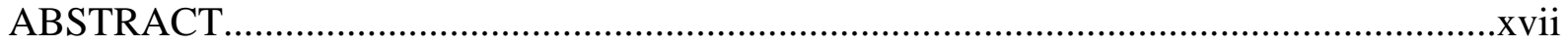

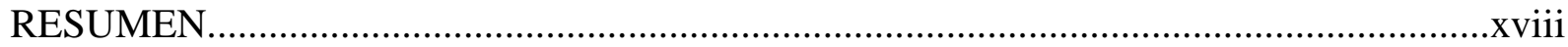

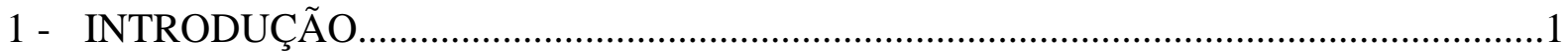

2 - LOCALIZAÇÃO GEOGRÁFICA DA ÁREA DE ESTUDO.............................................2

3 - OBJETIVOS E JUSTIFICATIVAS.........................................................................4

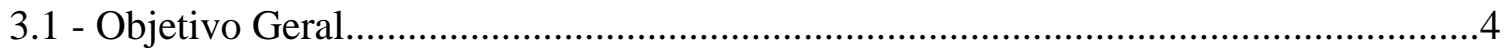

3.2 - Objetivos Específicos........................................................................................

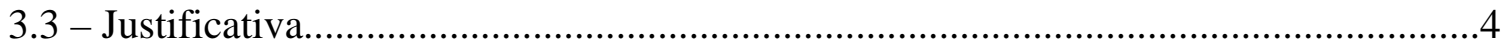

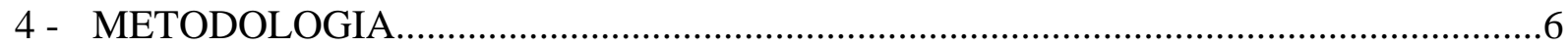

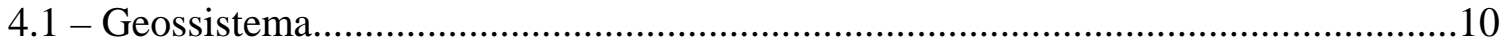

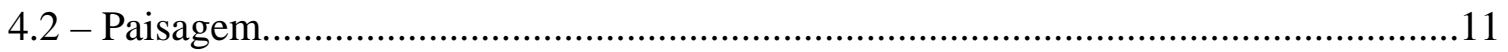

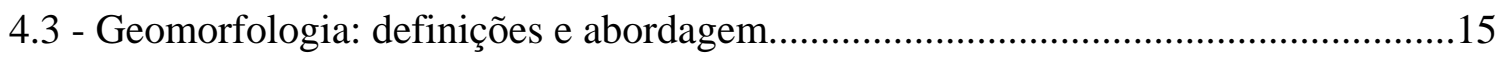

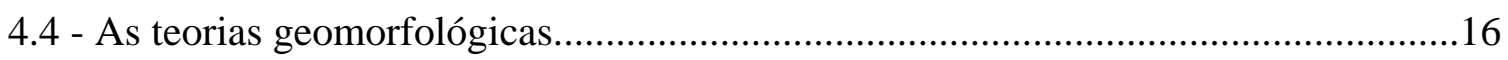

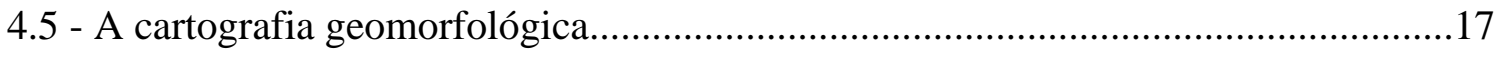

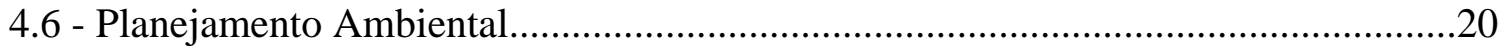

4.7 - A bacia hidrográfica como unidade de pesquisa......................................................23

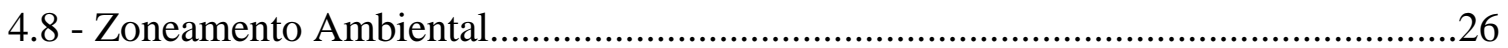

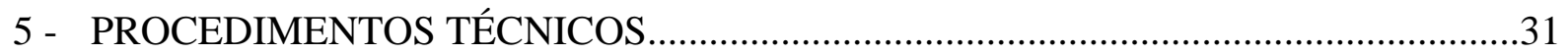

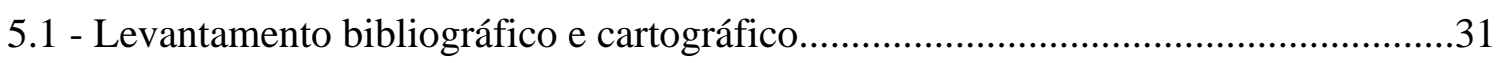

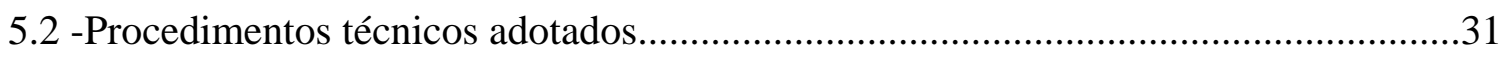

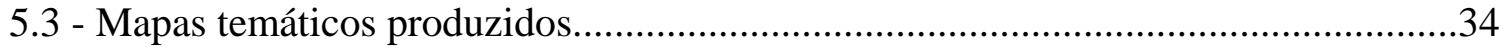

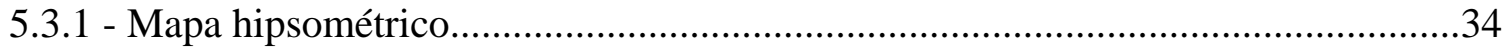




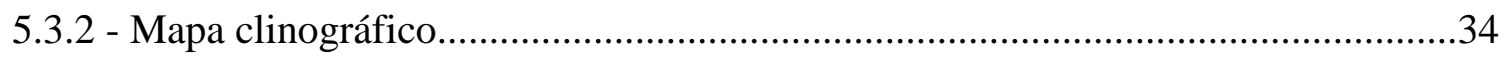

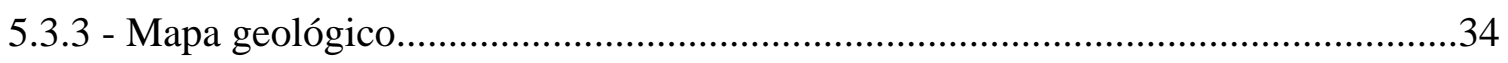

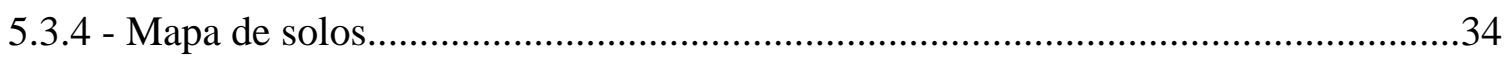

5.3.5 - Mapa de unidades de relevo....................................................................................34

5.3.6 - Mapa de ocupação e uso da terra - 2006...................................................................35

5.3.7 - Mapa de fragilidade ambiental.............................................................................35

5.3.8 - Mapa de legislação ambiental...............................................................................35

5.3.9 - Mapa de zoneamento ambiental..............................................................................36

5.4 - Medição de vazão do rio Biguaçu..............................................................................36

5.4.1 - Medição com flutuadores......................................................................................37

5.4.2 - Cálculo de vazão................................................................................................38

6 - CARACTERIZAÇÃO GEOGRÁFICA: Resultados da pesquisa........................................40

6.1 - O Ambiente Humanizado....................................................................................

6,1,1 - Histórico de colonização de Biguaçu......................................................................40

6.1.2 - Histórico de colonização de Antônio Carlos............................................................41

6,1.3 - Aspectos Humanos de Biguaçu............................................................................43

6.1.4 - Aspectos Humanos de Antônio Carlos....................................................................46

6.2 - Aspectos sócio- econômicos.....................................................................................47

6.2.1 - A estrutura agrária dos municípios de Biguaçu e Antônio Carlos...........................47

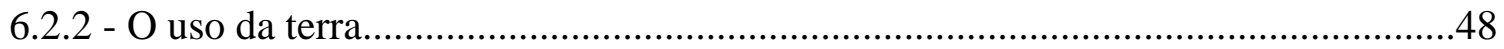

6.2.2.1 - Mapa de ocupação do uso da terra - 2006............................................................63

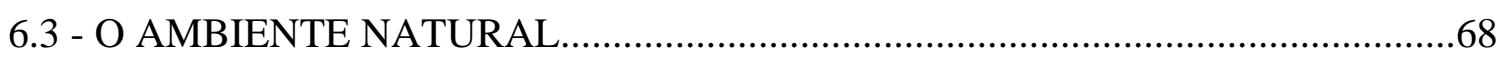

6.3.1 - Características geológicas...................................................................................68

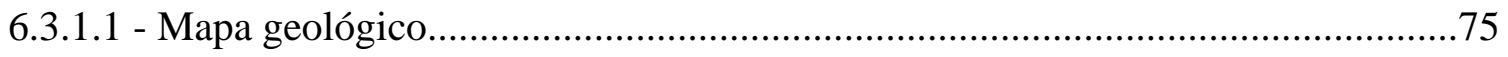

6.3.2 - Características geomorfológicas.......................................................................78

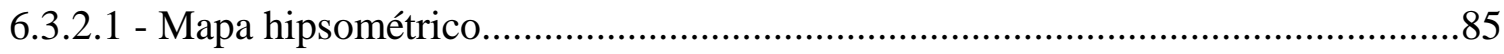

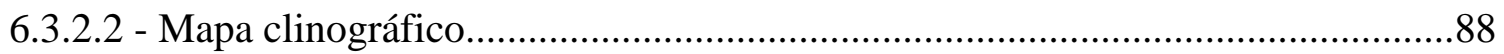

6.3.2.3 - Mapa de unidades de relevo..........................................................................90

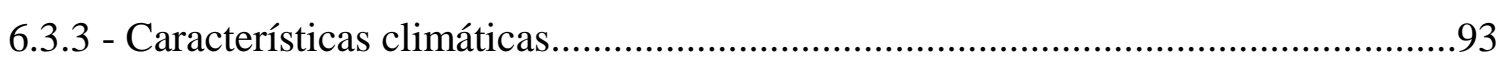

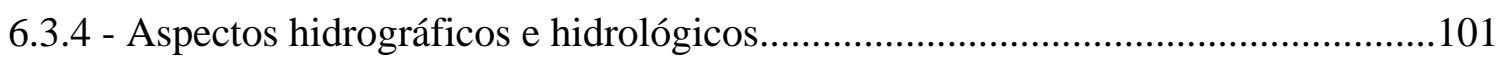

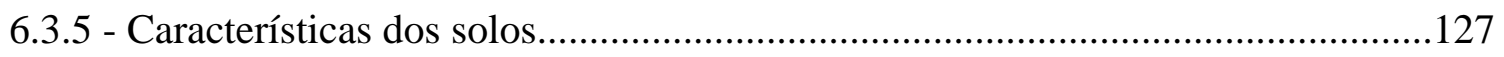




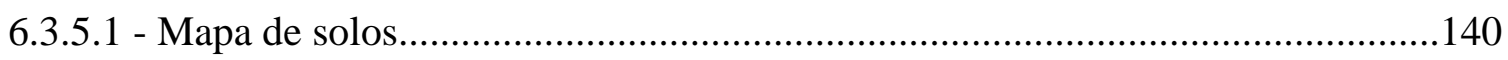

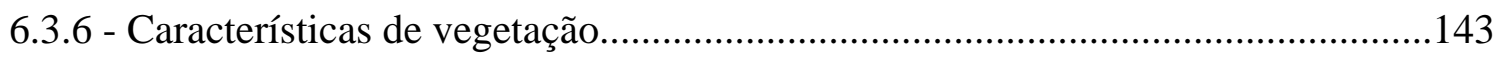

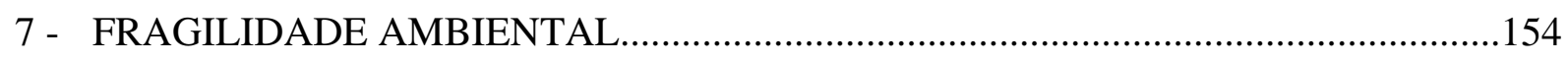

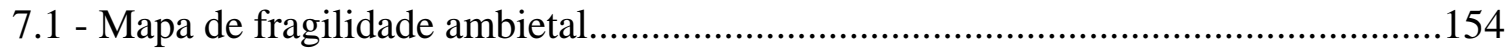

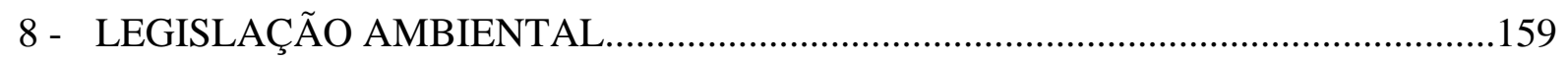

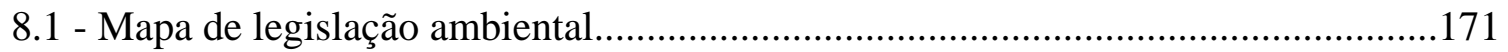

9 - DIRETRIZES PARA ORDENAMENTO TERRITORIAL E AMBIENTAL................174

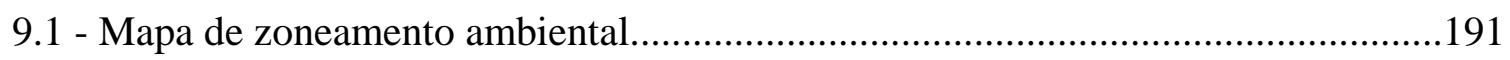

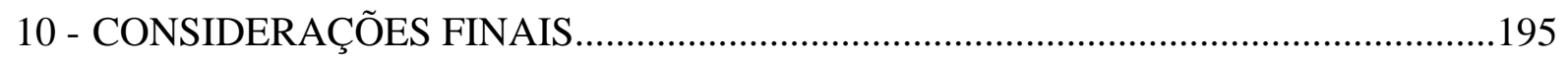

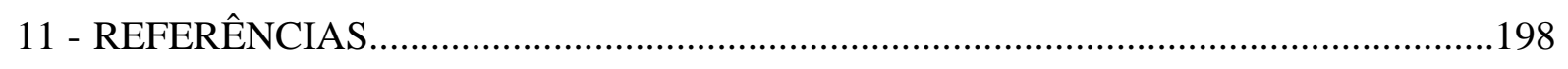




\section{LISTA DE FIGURAS}

1-Localização geográfica da área de estudo.................................................................... 3

2-Fluxograma de atividades e produtos da pesquisa...................................................... 39

3-Baixo vale do rio Biguaçu, vista do bairro Jardim Tibúrcio (Serra de São Miguel), 43 na cidade de Biguaçu-SC.

4-Vista parcial da cidade de Antônio Carlos-SC, em destaque a Igreja Matriz.............. 46

5-Solo preparado para o cultivo de hortaliças as margens do rio Biguaçu, no município 50

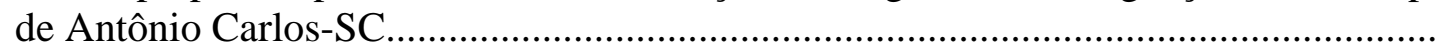

6-Vista do vale do rio Três Riachos, com plantação de arroz e pastagens na planície e 51 vegetação secundária nas encostas. Foto tirada do topo da colina (Igreja de São

Sebastião de Limeira, na localidade de Limeira, em Biguaçu-

SC.

7-Detalhe do vale do rio Rachadel, em $1^{\circ}$ plano, depósito de barra em pontal, em zona de pastagens, na localidade de Rachadel, no município de Antônio Carlos-SC......

8-Vale do rio Três Riachos. Ao fundo Serra de Guiomar (morro da Oratória). Uso da terra, pastagens e hortaliças, no município de Antônio Carlos-SC..

9-Planície fluvial do rio Biguaçu. Ao fundo, Serra de São Miguel. Uso da terra, pastagens, município de Biguaçu-SC.

10-Fundo de vale do ribeirão Vermelho. Uso da terra, pastagens e plantio de grama, na localidade de Canudos, no município de Antônio Carlos-SC.

11-Aspecto do uso da terra, com pastagens, horticultura e eucaliptos no alto curso do rio Biguaçu, na localidade Alto Egito, município de Antônio Carlos-

SC.

12-Plantio de grama as margens da SC-408 e ao fundo a Base da Petrobrás na localidade Santa Cruz, município de Biguaçu-SC.

13- Mapa de Ocupação do uso da terra da bacia do rio Biguaçu-SC.

14 - Vista em detalhe de afloramento de elúvio com cerca de 40 metros de espessura (material de empréstimo), no município de Antônio Carlos-SC.

15 - Mapa geológico da bacia do rio Biguaçu-SC.

16 - Aspecto do vale do rio Biguaçu, com pastagens na planície e o cultivo de banana, eucaliptos e vegetação secundária na encosta do morro, município de Antônio CarlosSC.

17-Área de pastagens e hortaliças no baixo vale do rio Farias no município de Antônio 
Carlos-SC.

18-Aspecto da planície do rio Guiomar, com cultivo de hortaliças na localidade

Guiomar de Fora, no município de Antônio Carlos-SC

19-Mapa hipsométrico da bacia do rio Biguaçu-SC

20-Mapa clinográfico da bacia do rio Biguaçu-SC

21-Mapa de unidades do relevo da bacia do rio Biguaçu-SC.

22-Foz do rio Três Riachos (margem esquerda) no rio Biguaçu, no município de Biguaçu-SC.

23-Baixo curso do rio Biguaçu, na zona urbana de Biguaçu. Ao fundo ponte da BR101 e Serra de São Miguel.

24-Canal retificado do rio do Louro, próximo à estrada que dá acesso a localidade de Santa Maria, município de Antônio Carlos-SC.

25 - Detalhe da desembocadura do rio Biguaçu-SC no distrito-sede de Biguaçu$\mathrm{SC}$

26 -Baixo curso do rio Farias. Detalhe da barra de meandros ( $1^{0}$ plano $)$ e terraço ao fundo até o contato com a base do morro, município de Antônio CarlosSC.

27-Balsa de sucção em operação na lagoa de mineração de areia na Mina Saudade, na margem direita do rio Biguaçu, no município de Biguaçu-SC.

28-Vale do rio Biguaçu, com draga de areia, estacionada na margem direita do rio, a montante da cidade de Antônio Carlos-SC.

29-Draga de extração de areia no leito do rio Biguaçu, na localidade Usina, no município de Antônio Carlos-SC

30- Seção topográfica transversal do canal do rio Biguaçu-SC, seção 1

31-Seção topográfica transversal do canal do rio Biguaçu-SC, seção 2.

32-Área de pastagens e hortaliças no vale do rio Braço do Norte, no município de Antônio Carlos-SC

33-Mapa de solos da bacia do rio Biguaçu-SC.

34- Vale do rio Biguaçu, próximo à cidade de Antônio Carlos. Aspecto do uso da terra com pastagens e ausência de mata ciliar. Ao fundo, vegetação secundária na encosta dos morros. 
35-Vale do rio Rachadel, com hortaliças cultivo de hortaliças e vegetação secundária

nos morros, na localidade Vila Doze de Outubro, município de Antônio CarlosSC

36-Aspecto do manguezal junto à foz do rio Biguaçu, na zona urbana de BiguaçuSC

37-Área da foz do rio Biguaçu, vista da barra de desembocadura. Na margem esquerda, vegetação de manguezal.

38-Mapa de fragilidade ambiental da bacia do rio Biguaçu-SC

39-Foz do rio Frias (direita) no rio Biguaçu (esquerda), na planície fluvial.Uso da terra com pastagens e ausência de mata ciliar, município de Antônio Carlos-SC.

40-Vista panorâmica do alto vale do rio Rancho Miguel, à jusante da cachoeira do rio, no município de Antônio Carlos-SC.

41-Planície fluvial no baixo curso do rio Biguaçu, com pastagens na margem esquerda do rio, no bairro do Prado, município de Biguaçu-SC.

42-Mapa de legislação ambiental da bacia do rio Biguaçu-SC.

43-Balsa de sucção de água, utilizada para a extração de areia, na margem esquerda do rio Biguaçu, no município de Biguaçu-SC.

44-Ocupação humana nas encostas do morro, no bairro do Prado, na Serra de São Miguel, município de Biguaçu-SC.

45-Rio Três Riachos , próximo a foz no rio Biguaçu, que apresenta corredeiras e mata ciliar, no município de Biguaçu-SC.

46-Médio curso do rio Biguaçu, com feições arrendondadas de relevo e cicatrizes de dissecação na encosta, com atuação de erosão com retirada de finos e exposição de matacões. Uso atual é com pastagens e ausência de mata ciliar, no município de Antônio Carlos-SC.

47-Aspecto meandrante do rio Biguaçu, com depósitos de areia nas margens, na localidade de Santa Maria, no município de Antônio Carlos-SC.

48-Ocupação humana nas margens do rio Caveiras (retificado), próximo à foz, no bairro Saveiro, na cidade de Biguaçu-SC.

49-Mapa de zoneamento ambiental da bacia do rio Biguaçu-SC. 


\section{LISTA DE TABELAS}

1-Distância recomendada entre verticais em função da largura do rio....................................37

2-População urbana e rural dos municípios de Biguaçu e Antônio Carlos-SC ........................45

3-Estrutura fundiária do município de Biguaçu-SC ............................................................48

4-Estrutura fundiária do município de Antônio Carlos-SC ......................................................48

5-Estabelecimentos por grupo de atividade econômica, segundo municípios de

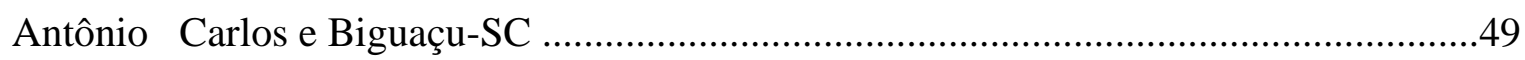

6-Distribuição de número de proprietários em relação à posse da terra no município

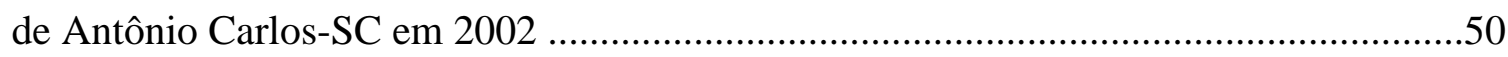

7-Utilização das terras no município de Biguaçu-SC (1970/1980/1985) ................................51

8-Utilização das terras no município de Antônio Carlos-SC (1970/1980/1985) ......................52

9-Classe de aptidão de uso das terras no município de Antônio Carlos-SC .............................53

10-Utilização das terras no município de Antônio Carlos-SC ..................................................53

11-Utilização das terras, segundo os municípios de Antônio Carlos e Biguaçu-SC ...............54

12-Produção agrícola do município de Biguaçu-SC ..............................................................55

13-Efetivos dos rebanhos do município de Biguaçu-SC. .....................................................57

14-Área total dos estabelecimentos agropecuários, segundo a utilização de terras nos municípios de Antônio Carlos e Biguaçu-SC .............................................................58

15-Produção agrícola do município de Antônio Carlos-SC ....................................................60

16-Efetivos dos rebanhos do município de Antônio Carlos-SC ............................................61

17-Unidades dos sistemas ambientais da bacia do rio Biguaçu-SC ........................................83

18-Direção dos ventos e freqüência (\%) .............................................................................97

19-Precipitação média (mm), por estação do ano em Biguaçu e Antônio Carlos-SC..............98

20-Precipitação média mensal (mm) em Biguaçu e Antônio Carlos-SC .................................98

21-Período de maior índice pluviométrico registrado em Biguaçu-SC .................................100

22-Precipitação máxima em 24 horas (mm) no período de 1926-2005, na Estação de São

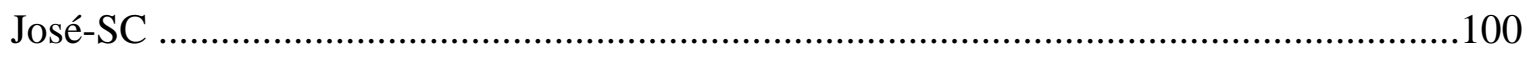

23-Número de dias de chuva ocorridos em um ano em Biguaçu-SC ...................................101

24-Medição da profundidade do canal do rio Biguaçu, no baixo curso, realizada em 1983

25-Dados da medição de vazão no baixo curso do rio Biguaçu no município de

Biguaçu-SC 


\section{LISTA DE QUADROS}

1-Unidades de intervenção da bacia do rio Biguaçu-SC

2-Situação atual por unidade de intervenção-áreas frágeis- da bacia do rio Biguaçu-SC......175

3-Situação atual por unidade de intervenção-áreas medianamente frágeis- da bacia do rio

Biguaçu-SC

4-Cenários tendencial e desejado da bacia do rio Biguaçu-SC.

5-Diretrizes gerais para a bacia do rio Biguaçu-SC.

6-Diretrizes específicas para áreas frágeis- Marinha 184

7-Diretrizes específicas para áreas frágeis- Manguezal 184

8-Diretrizes específicas para áreas frágeis- Planície Fluvial...............................................185

9-Diretrizes específicas para áreas medianamente frágeis- Serra de São Miguel ..................186

10-Diretrizes específicas para áreas medianamente estáveis- Planalto de Biguaçu/Três Riachos

11-Diretrizes específicas para áreas medianamente estáveis- Planalto de Cimeira .188 
1-ANA -Agência Nacional de Águas

2-APP -Área de Preservação Permanente

3-APREMABI -Associação de Preservação do Meio Ambiente de Biguaçu

4-BID -Banco Interamericano de Desenvolvimento

5-BIRD -Banco Internacional para Reconstrução e Desenvolvimento

6-CASAN -Companhia Catarinense de Águas e Saneamento

7-CEF -Caixa Econômica Federal

8-CELESC -Centrais Elétricas de Santa Catarina

9-CONAMA -Conselho Nacional de Meio Ambiente

10-DIGEO/SUL -Divisão de Geociências do Sul (IBGE)

11-DNPM -Departamento Nacional de Produção Mineral

12-DNOS -Departamento Nacional de Obras e Saneamento

13-EPAGRI -Empresa de Pesquisa Agropecuária e Extensão Rural de Santa Catarina

14-EMBRAPA -Empresa Brasileira de Pesquisa Agropecuária

15-EMBRATUR -Instituto Brasileiro de Turismo

16-FATMA -Fundação de Amparo à Tecnologia e ao Meio Ambiente

17-FFLCH -Faculdade de Filosofia, Letras e Ciências Humanas

18-FGTS -Fundo de Garantia por Tempo de Serviço

19-FNMA -Fundo Nacional de Meio Ambiente

20-GERCO -Gerenciamento Costeiro

21-IBAMA -Instituto Brasileiro do Meio Ambiente e dos Recursos Naturais Renováveis

22-IBGE -Instituto Brasileiro de Geografia e Estatística

23-INPE -Instituto Nacional de Pesquisas Espaciais

24-MME -Ministério do Meio Ambiente

25-OGU -Orçamento Geral da União

26-PMAC -Prefeitura Municipal de Antônio Carlos

27-PMB -Prefeitura Municipal de Biguaçu

28-PNMA -Programa Nacional de Meio Ambiente

29-PNMT -Programa Nacional de Municipalização do Turismo

30-PRODETUR -Programa de Ação para o Desenvolvimento Integrado do Turismo 
31-PROGEST -Programa de Apoio à Gestão de Sistemas de Coleta e Disposição de Resíduos Sólidos

32-PROSANEAR -Programa de Saneamento

33-RPPN -Reserva Particular de Patrimônio Natural

34-SANTUR -Santa Catarina Turismo

35-SDS -Secretária de Políticas para o Desenvolvimento Sustentável do MMA

36- SEDU/PR -Secretaria Especial de Desenvolvimento Urbano da Presidência da República

37-SIGERCO -Sistema Nacional de Informações do Gerenciamento Costeiro

38-SIG -Sistema de Informações Geográficas

39-SRH -Secretaria de Recursos Hídricos do MMA

40-UC -Unidade de Conservação

41-USP -Universidade de São Paulo

42-ZEE -Zoneamento Ecológico-Econômico 


\section{RESUMO}

O estudo "Análise sócio-ambiental da bacia do Rio Biguaçu - SC: subsídios ao planejamento e ordenamento territorial” objetiva a análise integrada de informações de aspectos naturais e sócio-econômicos, que permitam o entendimento na perspectiva geográfica para fins de planejamento territorial ambiental. A área da bacia é de 389,7 km2, compreendendo todo o município de Antônio Carlos e grande parte do município de Biguaçu. A geologia é formada pelos terrenos pré-cambriano e cobertura sedimentar cenozóica de origem fluvial e marinha. Na geomorfologia, o embasamento cristalino corresponde ao modelado de dissecação (75,97\% da área total da bacia) e os depósitos quaternários são representados pelo modelado de acumulação (24,03\% do total da bacia). Os solos dominantes são os cambissolos, seguidos dos argissolos vermelho-amarelos, gleissolos e neosssolos. A vegetação típica é a mata atlântica, sendo dominante a vegetação secundária (capoeirões e capoeiras). Foram produzidos nove mapas temáticos: hipsométrico, clinográfico, geológico, unidades do relevo, solos, ocupação e uso da terra, fragilidade ambiental, legislação ambiental e zoneamento ambiental, todos na escala original 1: 50.000. Os problemas ambientais levantados na pesquisa foram: ausência de mata ciliar ao longo dos rios em áreas de preservação permanente, poluição dos recursos hídricos superficiais por esgotos domésticos e resíduos de agrotóxicos, lixo, erosão nas margens dos rios e assoreamento da foz do rio Biguaçu. No município de Biguaçu a indústria química (plásticos) é a principal atividade econômica. Destaca-se também o cultivo de grama e de hortaliças. No município de Antônio Carlos o destaque da economia é o cultivo de hortaliças. No mapa de zoneamento ambiental foram definidas zonas produtivas (rural e urbana) e a zona de restrições legais (vegetação secundária, manguezal, área de proteção permanente de rios e RPPN). Nas diretrizes para o ordenamento territorial ambiental foram propostas seis unidades de intervenções e gestão: marinha, flúviomarinha, planície fluvial, Serra de São Miguel e Planalto de Biguaçu/Três Riachos e Planalto de Cimeira. Foram propostas ações visando a mitigação do quadro geral de degradação ambiental na qual está inserida a bacia do rio Biguaçu. Através de projetos e estudos, as ações sugeridas visam a compatibilização da utilização econômica dos recursos da natureza com a preservação do meio físico-biótico, promovendo a qualidade de vida das populações humanas.

Palavras-chave: Rio Biguaçu, geomorfologia, uso da terra, legislação ambiental, zoneamento territorial. 


\begin{abstract}
"Socio-environmental analysis of Biguaçu River Basin - SC: subsides to the planning and territorial ordaining" is a study that aims to an integrated analysis of information on the natural and socio-economical aspects which. The basin area is of $389.7 \mathrm{Km} 2$, and contains all Antonio Carlos District and most of Biguaçu District. The geology is formed by the Precambrian lands and Cenozoic sedimentary cover from fluvial and marine origin. In geomorphology, the crystalline base corresponds to the dissection modeling (75.97\% of the basin total area) and the quaternary deposits are represented by the accumulation modeling (24.03\% of the total of the basin). The dominating soils are the Cambisoils, followed by the red-yellow Clay soils, Gley soils and Neosoils. The typical vegetation is the Atlantic Tropical Forest, in which the secondary vegetation is dominant (dense forest and coppice). Nine thematic maps have been produced: hypsometric, clinographic, geologic, relief unities, soils, occupation and soil usage, environmental fragility, environmental legislation and environmental zoning, all in the original scale of 1:50.000. The following environmental problems have been found in the research: lack of riparian vegetation in areas of permanent preservation, superficial hydric recourses polluted by domestic sewage and agrotoxic waste residues, garbage, erosion on the margins of the rivers and silting of Biguaçu River mouth. In Biguaçu District, the chemical industry (plastics) is the main economical activity. Grass and vegetable growth is also a highlight. In Antonio Carlos District the most important activity is the vegetable growth. In the environmental zoning map, productive zones (rural and urban) and the legal restriction zone (secondary vegetation, mangrove, river permanent protection area and RPPN) have been defined. In the guidelines for the environmental territorial ordaining, six units of intervention and management have been proposed: marine, fluvial-marine, fluvial plain, São Miguel mountain chain and Biguaçu plateau/Três Riachos and Cimeira plateau. Actions have been proposed, aiming to a mitigation of the general picture of environmental degradation in which is Biguaçu River Basin. Through projects and studies, the suggested actions aim to the compatibilization of the economical utilization of the natural resources, with the preservation of the physical-biotic environment, promoting life quality for the human populations.
\end{abstract}

Key words: Biguaçu River, geomorphology, soil usage, environmental legislation, environmental zoning. 


\section{RESUMEN}

“Análisis socioambiental de la cuenca del río Biguaçu - SC: se desploma al planeamiento y ordenación territorial” es un estudio que apunta a un análisis integrado de la información sobre los aspectos naturales y socioeconómicos que permitirían la comprensión de la perspectiva geográfica que apunta a un planeamiento territorial ambiental. El área de la cuenca esde $389.7 \mathrm{~km} 2$, e incluye todo el districto de Antonio Carlos y la mayor parte del districto de Biguaçu. La geología es formada por las tierras precámbricas y la cubierta sedimentaria cenozoica del origen fluvial y marina. En geomorfología, la base cristalina corresponde al modelado de disección (75.97\% del área total de la cuenca) y los depósitos cuaternarios son representados por el modelado de la acumulación (24.03\% del total de la). Los suelos dominantes son el cambisolos, seguido por los suelos rojo-amarillos de la arcilla, los suelos de Gley y Neosolos. La vegetación típica es el bosque tropical atlántico, en el cual la vegetación secundaria es dominante (bosque y soto densos). Se han producido nueve mapas temáticos: hipsométrico, clinográfico, geológico, unidades del relieve, suelos, ocupación y uso de la tierra, fragilidad ambiental, legislación ambiental y zonificación ambiental, todos en la escala original de 1:50.000. Los problemas ambientales que se han encontrado en la investigación fueron: carencia de la vegetación ciliar en áreas de la preservación permanente, contaminación de los recursos hídricos superficiales por las aguas residuales domésticas y los residuos de agrotóxicos, de la basura, de la erosión en las orillas de los ríos y del enarenamiento de la boca de río Biguaçu. En el districto de Biguaçu, la industria química (plásticos) es la actividad económica principal. El cultivo de la hierba césped y de hortalizas es también un toque de luz. En el districto de Antonio Carlos la actividad más importante es elcultivo de hortalizas. En el mapa de la zonificación ambiental se han definido las zonas productivas (rurales y urbanas) y la zona legal de la restricción (vegetación secundaria, mangues, área permanente de protección del río y RPPN). En las pautas para ordenación territorial ambiental, se han propuesto seis unidades de intervención y gestión: marina, fluvialmarinas, llanura fluvial, Sierra de São Miguel y meseta de Biguaçu/meseta de Três Riachos y de Cimeira. Las acciones se han propuesto, apuntando a una mitigación de la visíon general de la degradación ambiental en la cual está la cuenca del río Biguaçu. Con proyectos y estudios, las acciones sugeridas apuntan a la compatibilización de la utilización económica de los recursos naturales, con la preservación del ambiente físicobiótico, promoviendo la calidad de vida para las poblaciones humanas.

Palabras clave: Río Biguaçu, geomorfología, uso de la tierra, legislación ambiental, zonificación ambiental. 


\section{1- INTRODUÇÃO}

As zonas costeiras constituem um complexo de sistemas ambientais marcados pela interação das várias geoesferas (litosfera, hidrosfera, atmosfera e biosfera), que promovem em estado natural o equilíbrio e funcionamento dinâmico da paisagem.

A ocupação humana, crescente e na maioria das vezes não planejada, tem gerado nos últimos anos uma acelerada degradação dos ambientes naturais. A alteração dos canais de drenagem por obras de retificação, a extração irregular de areias dos leitos dos rios, os aterros inadequados em manguezais, o traçado de rodovias, a exploração de pedreiras e o manejo inadequado da terra para fins agrícolas em declividades acentuadas, são alguns exemplos de interferências desastrosas no ambiente natural desta zona costeira. Em grande parte, estas ações resultam da falta de um conhecimento básico dos múltiplos processos naturais que nela ocorrem.

O desenvolvimento tecnológico em ritmo exponencial foi responsável pelo impacto do uso indiscriminado dos recursos naturais, especialmente nas áreas costeiras. O fator determinante na exploração destes recursos foi a concentração populacional motivada pela expansão das atividades econômicas e pelas características paisagísticas que podem propiciar melhorias nas condições de vida locais. Se por um lado, este desenvolvimento acelerado foi responsável por tão profundas alterações ambientais, por outro, ele poderá contribuir ao menos parcialmente, na recuperação, solução e prevenção dos mesmos problemas. $\mathrm{O}$ restabelecimento e proteção do meio ambiente somente logrará êxito se a ciência ultrapassar as concepções meramente positivistas, para uma visão holística em que a multi e a transdisciplinariedade constituem a base metodológica para análise ambiental.

Dentre as diversas áreas do conhecimento humano, a geomorfologia fornece importantes subsídios ao estudo multidisciplinar do meio ambiente. De acordo com Tricart (1976), a renovação da geomorfologia, fortalecida de métodos e concepções novos, é capaz de desempenhar seu importante papel na enorme tarefa que o homem moderno enfrenta: salvaguardar as riquezas naturais e utilizá-las melhor visando o bem-estar da sociedade. 
A ênfase que foi dada à análise dos processos e das interações de fatores, imprimiu características pragmáticas à geomorfologia. Na análise ambiental, para fins de planejamento regional ou global, a geomorfologia tem contribuído efetivamente e várias propostas metodológicas têm sido apresentadas, dado a importância do relevo nas atividades humanas.

A bacia hidrográfica do rio Biguaçu, situada próxima à capital do estado de Santa Catarina - Florianópolis, vem sofrendo grandes impactos relacionados à ocupação humana. No contexto estadual, é uma das áreas que mais urgentemente requer medidas que harmonizem a exploração do vale com a necessária prevenção dos ambientes naturais, como as praias, os manguezais e as encostas.

Os inúmeros conflitos que nos últimos anos têm surgido, contrapondo, de um lado, as tentativas de exploração econômica pelas municipalidades e, de outro lado, a necessidade de preservar os sistemas naturais, testemunham a urgência de se estabelecer um plano de gerenciamento para todo o vale. Para tal é de fundamental importância, não apenas o estabelecimento de critérios para o uso e ocupação desta área, mas também a identificação e delimitação de zoneamento ambiental, para que esta subsidie o planejamento de toda bacia.

\section{2-LOCALIZAÇÃO GEOGRÁFICA DA ÁREA DE ESTUDO}

A bacia hidrográfica do rio Biguaçu, localizada na região central do litoral catarinense, é limitada pelas coordenadas $27^{\circ} 22^{\prime}$ e $27^{\circ} 34^{\prime}$ de latitude Sul e $48^{\circ} 56^{\prime}$ e $48^{\circ} 38^{\prime}$ de longitude Oeste de Greenwich (fig. 1).

A referida bacia possui uma área de aproximadamente $389,7 \mathrm{~km}^{2}$, compreendendo o município de Antônio Carlos e grande parte do município de Biguaçu, ambos pertencentes à microrregião de Florianópolis. As principais vias de acesso da área de estudo estão representadas pelas rodovias federal BR-101 e estadual SC-408. A primeira liga Biguaçu a Florianópolis - SC ao sul (distância de 18 km) e a Itajaí ao norte (aproximadamente 90 km de distância). A segunda liga Biguaçu a Antônio Carlos numa distância de 15 km. Outras estradas secundárias, não pavimentadas e de acesso precário, permitem cruzar a bacia em várias direções, possibilitando acesso a toda área de pesquisa. 


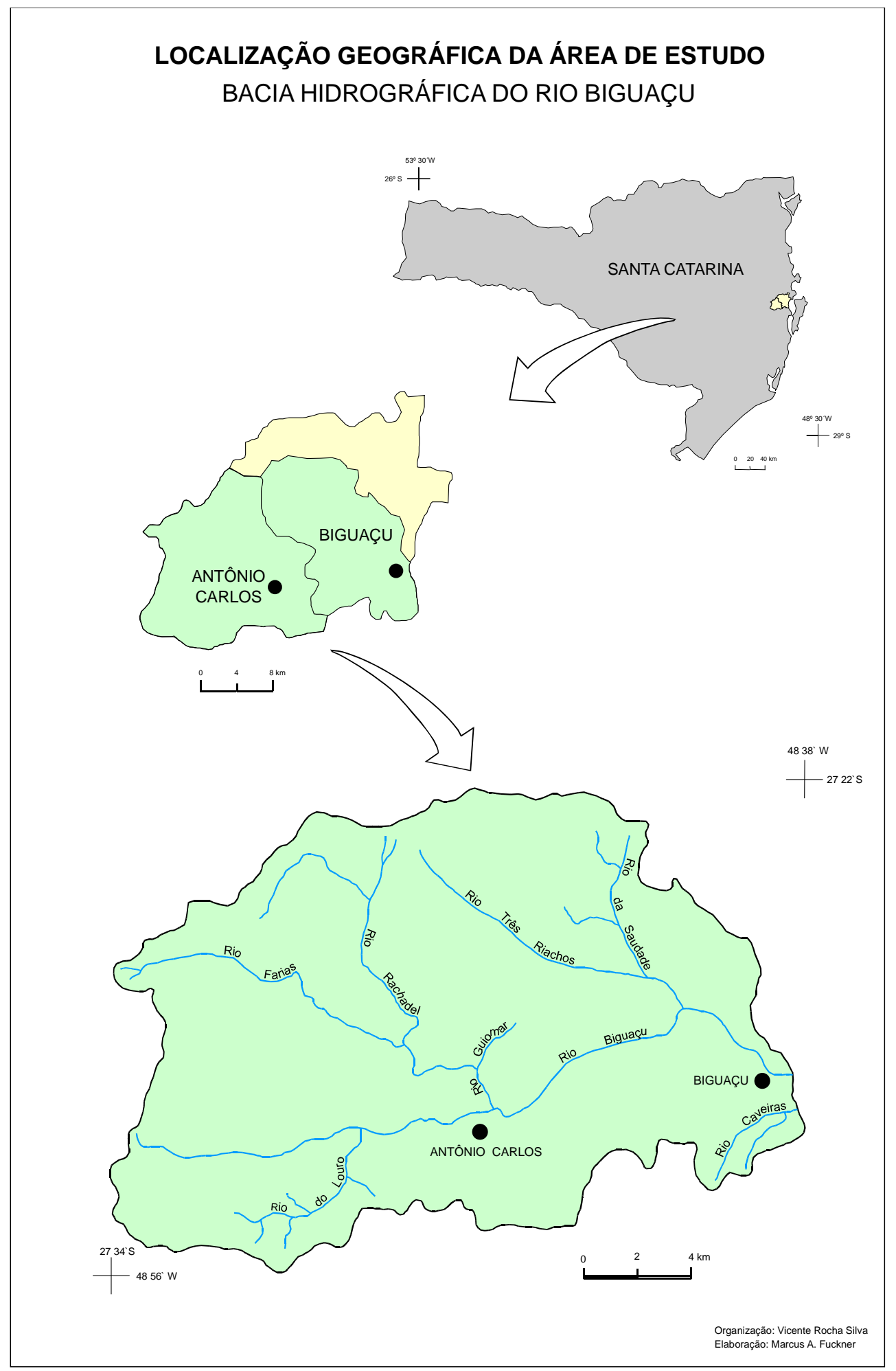

Figura 1 - Mapa de localização geográfica da área de estudo. 


\section{3 - OBJETIVOS e JUSTIFICATIVA}

\section{1 - Objetivo Geral}

Tendo eleito como área de pesquisa a bacia hidrográfica do rio Biguaçu, no estado de Santa Catarina, tem-se em com objetivo central a análise sócio-ambiental, fundamentada através do estudo da dinâmica natural dos compartimentos da bacia: serra, a planície fluvial e costeira do rio Biguaçu e as transformações decorrentes das atividades humanas. Portanto, sobre a base de estudos e investigações utilizar-se-á a análise dos recursos naturais e dos fatores sócio-econômicos, visando a identificação e hierarquização das unidades ambientais para fins de zoneamento ambiental.

\section{2- Objetivos Específicos}

a) Delimitar e caracterizar as unidades ambientais da área;

b)Identificar os usos da terra e os conflitos, frente à legislação ambiental;

c)Proceder um zoneamento ambiental na área, a fim de subsidiar o direcionamento do ordenamento territorial;

d)Propor diretrizes de ordenamento territorial, visando atenuar os impactos ambientais e a promoção do desenvolvimento com conservação ambiental.

\section{3- Justificativa}

Os problemas ambientais da área estão em grande parte interligados produzindo com isto um efeito em cadeia. O principal deles refere-se as enchentes, que periodicamente afetam a bacia, principalmente na zona urbana de Biguaçu, produzindo efeitos catastróficos à economia dos municípios de Biguaçu e Antônio Carlos. Apesar das causas naturais, a intervenção humana nos sistemas ambientais diminuiu a freqüência e a intensidade das enchentes. Esta intervenção ocorreu através de obras de retificação dos principais canais fluviais, visando a regularização do regime hidrológico da bacia do rio Biguaçu.

Problemas específicos, como a destruição de manguezais por aterros (rio Caveiras), a contaminação das águas do rio Biguaçu e da Baía Norte por lançamentos de esgotos e lixo sólido, a retificação de canais do rio Biguaçu e de tributários, a extração mineral (granito, 
areia e saibro), os desmatamentos, os ravinamentos, entre outros, foram também observados na região.

No vale do ribeirão Vermelho, áreas naturais de várzeas, onde ocorriam fauna e flora específicas, foram modificadas na sua dinâmica natural, através da retificação, visando atenuar as inundações. Nestas áreas o uso atual é com pastagens, hortaliças e cultivo de grama para jardinagem, no município de Antônio Carlos.

Em virtude dos inúmeros problemas apontados, que afetam tanto em extensão como em intensidade o meio ambiente na bacia, tornam-se necessárias medidas urgentes visando conter os processos de degradação e recuperar as áreas já degradadas, através de soluções práticas, que conciliem o desenvolvimento econômico da população e dos municípios, como também a preservação/conservação da natureza.

Proposição

A questão ambiental refere-se em primeiro lugar às situações de transformação das condições naturais que se manifestam de maneira geral e potencial, resultantes da ação do homem no seu esforço em explorar os recursos naturais para atender suas necessidades de ordem econômica, social, cultural, estética e de lazer. Na maioria das vezes, prevalece a exploração econômica, provocando alterações básicas do ambiente, comprometendo a qualidade de vida das populações (Armus, 1990, p.286).

O problema a ser enfocado diz respeito à análise sócio-ambiental da bacia do rio Biguaçu, em Santa Catarina, que permitiu a elaboração de um estudo dos diversos componentes da natureza e as transformações econômicas e sociais do espaço geográfico. A ocupação humana mais efetiva na região, para a fixação de moradias e apropriação dos recursos naturais visando as necessidades básicas de subsistência, promoveu as transformações no espaço natural com a retirada de madeira para construção de casas, os desmatamentos, o cultivo da terra e a criação de gado, etc.

As alterações humanas provocam mudanças na intensidade dos fluxos de energia e matéria, porém não modifica o funcionamento geral dos geossistemas. A deteorização dos ambientes decorre da exploração dos recursos naturais de forma predatória, conflitantes com a vocação natural do meio, como da produção e geração de resíduos do setor primário, secundário e urbano. Portanto, as ações do homem através de atividades de produção e 
consumo, numa quantidade superior ao que o ambiente pode assimilar, causam desequilíbrios nos componentes dos ambientes.

A questão ambiental constitui-se num problema multifacetado formado pelos componentes científicos, políticos, econômicos, jurídicos e sociais. É nesse contexto que a pesquisa dá uma contribuição valiosa ao estudo no sentido de buscar um conhecimento totalista e integrado do ambiente natural e do seu comprometimento face às ações do homem (Armus, 1990, p.286). Assim, a presente pesquisa objetiva realizar uma análise geográfica de informações de aspectos naturais e sócio-econômicos, que resultem num entendimento da perspectiva de totalidade geográfica da bacia do rio Biguaçu, com fins ao planejamento ambiental territorial.

\section{4- METODOLOGIA}

O estudo proposto por envolver as diversas interfacies requer uma análise integrada dos diversos elementos para tornar possível a delimitação dos compartimentos ambientais, partindo-se da concepção sistêmica. Esta decorre da teoria geral dos sistemas, cujas origens advêm das ciências biológicas. Nesta concepção o organismo vivo é representado como um sistema de componentes em interação mútua e dinâmica. O comportamento do organismo é assim descrito por “leis gerais do sistema orgânico” (Bertalanffly, 1937). Verificou-se com o tempo que a teoria geral dos sistemas proposta inicialmente para as ciências biológicas, tinha validade para outros sistemas organizados nos mais diversos campos da ciência, de tal modo que tornou possível a formulação de uma teoria geral do sistema, cujo objetivo era a unificação do conhecimento científico.

O biólogo Ludwig von Bertalalanffy apresentou de forma sistematizada, a Teoria Geral dos Sistemas, em 1947, com objetivo de superar a dicotomia mecanicista no estudo da biologia.

O referido autor propôs uma nova concepção de biologia “organísmica”, visando compreender os níveis mais elevados da organização da matéria viva (Bertalanffy, 1975, p.21).

O conceito de "sistema” surgiu como conceito-chave na pesquisa científica. A pesquisa dos sistemas avança sobre novas áreas do conhecimento da ciência, unindo 
disciplinas científicas e aplicadas. É objetivo chegar a uma síntese do conhecimento jamais atingida (Ackoff, 1959 apud Bertalanffy 1975, p.26).

Como obras preliminares no campo da teoria geral dos sistemas, temos o trabalho de Lotka (1925). Esse autor apresentou um conceito geral de sistemas. Bertalanffy (op. cit.), descreve bem a sua preocupação com os rumos da biologia, no início de sua carreira e diz: “O autor desse livro, na década de 1920, ficou intrigado com as evidentes lacunas existentes na pesquisa e na teoria da biologia. O enfoque mecanicista então prevalece e parecia desprezar ou negar de todo exatamente aquilo que é essencial no fenômeno da vida. O autor advogava uma concepção organísmica na biologia, que atenuasse a consideração do organismo como totalidade ou sistema e visse o principal objetivo das ciências biológicas, na descoberta de princípios da organização em seus vários níveis” (Bertalanffy, 1975, p.29).

Uma das principais utilidades da teoria geral dos sistemas seria a formulação de princípios válidos para os "sistemas" em geral, seja qual for a natureza de que são formados e as relações existentes entre eles (Bertalanffy, 1975, p.61). O autor reafirma em seu trabalho, que "todo organismo vivo é essencialmente um sistema aberto", sendo mantido por um fluxo de entrada e saída de elementos essencias a sua manutenção como ser vivo.

Os processos realizados na teoria geral dos sistemas procuram defini-la como: "a que procura derivar da definição geral de sistema como complexo de componentes em interação, conceitos característicos das totalidades organizadas, tais como interação, soma, mecanização, centralização, competição, finalidade, etc., e aplicá-los a fenômenos concretos” (Bertalanffy, 1975, p.128).

Os avanços da teoria geral dos sistemas chegaram ao âmbito do sistema aberto, de aplicação na ciência da terra, com destaque na geomorfologia Chorley (1964) apud Bertalanffy (1975, p.144). A bacia hidrográfica é um exemplo típico de sistema aberto, onde há troca de matéria e energia com o ambiente, ocorrendo importação e exportação, construção e destruição dos materiais que os integram (Bertalanffy, 1975, p.193).

A concepção sistêmica baseia-se em termos de relações e integração e considera os sistemas como totalidades integradas. Os "sistemas naturais são totalidades cujas estruturas resultam das interações e interdependência de suas partes” (Capra, 2005, p.260). O referido autor diz que "o pensamento sistêmico é pensamento de processo; a forma torna-se associada 
ao processo, a inter-relação, a interação, e os opostos são unificados através da oscilação” (Capra, 2005, p.261).

Na tipologia clássica de sistemas, os objetos de estudo das geociências correspondem a sistemas abertos (Huggett, 1985). Procurando estabelecer critérios de classificação de sistemas, a geografia física contribuiu para análise sistêmica através dos trabalhos de Weaver (1958) apud Huggett, (1985), Chorley ; Kennedy (1971), Terjung (1976) e Strahler (1980). O primeiro classificou os sistemas em função da complexidade e organização. Os três últimos classificaram os sistemas quanto ao nível de descrição sendo definido de três modos diferentes: em termos de formas externas, em termos de processos (fluxo de matéria e energia) e em termos de relações entre processos e formas resultantes.

\section{A Classificação dos Sistemas em Geomorfologia.}

Essa classificação está baseada no critério funcional de acordo com sua complexidade estrutural. Os sistemas não isolados possuem relações com os demais sistemas do universo, sendo subdivididos em abertos. Os sistemas não isolados do tipo aberto são aqueles onde ocorrem constantes trocas de energia e matéria. Os sistemas abertos são os mais comuns, sendo representados pelo homem, cidade, bacia hidrográfica, vertente, etc (Christofoletti, 1980, p.3).

Ainda no âmbito da geomorfologia, podemos destacar os sistemas morfológicos, os sistemas em sequência e os sistemas de processos-respostas. Os sistemas morfológicos são definidos pela associação de propriedades físicas dos fenômenos (geometria, composição). Trata-se das formas que apresentam algumas variáveis a serem medidas (comprimento, altura, largura, declividade, granulometria, densidade). Os sistemas morfológicos possuem propriedades visando a "resposta ou ajustamento ao fluxo de energia em matéria através dos sistemas em sequência aos quais estão ligados” (Christofoletti, 1980, p.4). Assim, podemos citar como integrantes desses sistemas, a rede de drenagem, as vertentes, os canais fluviais, os manguezais, sendo possível distinguir, medir e correlacionar as variáveis geométricas e as de composição (op. cit.).

Os sistemas em sequência são um conjunto de subsistemas, e este apresenta abrangência espacial e localização geográfica, segundo um fluxo de matéria e energia. Nesse 
aspecto, "a saída de matéria e energia de um subsistema torna-se a entrada para outro subsistema de localização adjacente” (Christofoletti, 1980, p.4).

Os sistemas de processos-respostas são formados pela combinação de sistemas morfológicos e sistemas em sequência. Os sistemas em sequências indicam o processo, enquanto o morfológico representa a forma, a resposta a determinado estímulo. Os sistemas processo-respostas têm como objetivo identificar as relações entre o processo e as formas que dele resultaram. Portanto, é possível ter um equilíbrio entre o processo e a forma, onde qualquer alteração no sistema em sequência terá repercussões na estrutura do sistema morfológico. Ocorrerá um reajustamento das variáveis, visando atingir um novo equilíbrio, configurando uma nova forma (Christofoletti, 1980, p.5).

O estudo das formas e os processos são essenciais na ciência geomorfológica. O sistema geomorfológico necessita para sua compreensão das formas de relevo, da contribuição dos seguintes sistemas antecedentes: o sistema climático, que através dos elementos do calor, da umidade e da circulação atmosférica, permite o dinamismo dos processos. O sistema geológico por meio das rochas e minerais fornece os materiais, tendo atuação passiva. O sistema biogeográfico é formado pela flora e fauna, onde atuam de forma integrada no ambiente, fornecendo e retirando matéria. O sistema antrópico tem na ação humana o principal responsável pelas modificações na distribuição da matéria e energia dentro de um sistema. A atuação humana voluntária ou involuntária "produz modificações sensíveis nos processos e nas formas, através das influências destruidoras ou controladoras sobre os sistemas em sequência” (Christofoletti, 1980, p.10-11).

No sistema geomorfológico ocorre o fluxo de matéria e energia, onde as saídas são formadas pelas descargas de água e de detritos, típicos de uma bacia hidrográfica. Em resumo, os quatro sistemas citados acima são os principais controladores dos sistemas geomorfológico, representando os seus fatores, o seu ambiente. Deve-se acrescentar que o sistema geomorfológico também atua sobre os demais sistemas, através dos mecanismos de retroalimentação (Christofoletti, 1980, p.11). 


\section{1-Geossistema}

Existem várias definições de geossistemas na literatura, seguem-se algumas. Maria Margarida Penteado (1983) o define como formações naturais que experimentam o impacto dos ambientes: social, econômico e técnico. A autora cita o geossistema como uma classe peculiar de sistemas dinâmicos, abertos e hierarquicamente organizados (Penteado, 1983, p.155). Outra contribuição diz que geossistema é "sistema ecológico reconhecível e delimitável no interior de um domínio morfoclimático, província de vegetação ou região natural (...). na caracterização ou delimitação dos geossistemas incluem-se as atividades humanas (...). Sua aplicabilidade se faz de modo preferencial por regiões fortemente humanizadas, (...)” (Aciesp, 1997, p. 132).

Na França, George Bertrand (1971) cita que o geossistema possui boa base para os estudos de organização do espaço, sendo compatível com escala humana. O autor acrescenta, “o geossistema está em estado de clímax quando há equilíbrio entre o potencial ecológico e exploração biológica”. O biogeógrafo afirma que todo geossistema tem o tripé: potencial ecológico, exploração biológica e ação antrópica. Ação antrópica depende da funcionalidade do geossistema (Bertrand, 1971).

Já o russo Soctchava (1978) recomenda que o estudo no contexto geossistêmico deve abordar as variáveis relevo, solo, clima, água, vegetação e as atividades humanas no lugar (metodologia sistêmica). O pesquisador entende a bacia hidrográfica como unidade sistêmica. Cada unidade sistêmica é um geossistema. O autor (op. cit.) acrescenta que todos os espaços geossistêmicos são passíveis de transformação pela natureza e mudança pela sociedade. Os fluxos de energia e matéria são alterados em um ritmo maior que da natureza (Soctchava, 1978).

O geógrafo Helmut Troppmair define geossistema como "um sistema natural complexo e integrado onde há circulação de energia e matéria e onde ocorre exploração biológica, inclusive aquela praticada pelo homem” (Troppmair, 2000, p. 5). Para o pesquisador, (...) paisagem é fato concreto, um termo fundamental e de importante significado para a geografia, pois a paisagem é a fisionomia do próprio geossistema (Troppmair, 2000, p. 8). 
Outra contribuição define geossistema como: (...) sistemas ambientais físicos, pois representam a organização espacial resultante da interação dos elementos físicos e biológicos da natureza (clima, topografia, geologia, águas, vegetação, animais, solos). É o campo de ação da geografia física. Os sistemas ambientais físicos possuem uma expressão espacial na superfície terrestre, funcionando através da interação areal dos fluxos de matéria e energia entre os seus componentes (Chistofoletti, 1999, p. 37).

A interdisciplinaridade, o globalismo, o ambientalismo e a análise dialética da natureza e da sociedade não poderão se desenvolver senão num ambiente científico, dominado pelo espírito de sistema ( ...) (Passos, 1988, p.67). O autor (op. cit.) explica que o conceito de geossistema foi definido pelo geógrafo soviético Soctchava, em 1963.

Há também Monteiro que utiliza o método sistêmico e esclarece que o "geossistema e sua análise é uma tentativa de melhoria na investigação da geografia física (...)” e conclui “(...) a modelização dos geossistemas a base de sua dinâmica espontânea e antropogênica e do regime natural e elas correspondente, visa promover uma maior integração entre o natural e o humano” ( Monteiro, 2000, p. 47). Monteiro (op. cit.), no final de obra, adverte que “(...) nada indica que se haja firmado no conceito de geossistema, e nem mesmo para a geografia física. Portanto, a procura do geossistema se apresentou como um programa de investigação em diferentes lugares, em diferentes geográficas. Apesar do esforço, o conceito, continua abstrato e irreal (...)” (Monteiro, 2000, p. 103).

No entanto Passos (1997) considera o geossistema um "novo paradigma” na geografia física, pois rompe uma tradição das monografias descritivas, subjetivas, elementaristas, e excepcionalistas (Passos, 1997, p. 42).

\section{2- Paisagem}

Desde o século XIX, o termo paisagem na geografia tinha como objetivo compreender as relações da sociedade e natureza no espaço geográfico. Devido às múltiplas abordagens geográficas, o significado de paisagens sempre teve diferentes interpretações. A definição de paisagem na escola alemã é de cunho científico e refere-se a um conjunto de fatores naturais e humanos. Na França sob a influência de Paul Vidal de La Blache e Jean Rochefort, a paisagem significava “o relacionamento do homem com o seu espaço físico”. 
Nos EUA, com o advento da revolução quantitativa, o termo "landscape" que tinha sido introduzido no país por influência de Carl Sauer, foi suplantado pela idéia de região. O termo região seria “o conjunto de variáveis abstratas deduzidas da realidade da paisagem e da ação humana”. Nesse mesmo período surge na Alemanha e no Leste Europeu uma visão mais holística e sinérgica da "landschaft”, que concebeu “as unidades de paisagem pelo conjunto dos seus processos ecológicos”(Schier, 2003, p.80).

De acordo com Schier (2003), as definições de paisagem estão relacionadas às abordagens filosóficas. Para esse autor o conceito de paisagem deriva do positivismo, sendo que na escola alemã, teve ênfase nos fatores geográficos agrupados em unidades espaciais. Já na geografia francesa o conceito de paisagem apresentou características dinâmicas, com destaque ao fato processual. Em ambas escolas, "a paisagem é uma face material do mundo, onde se imprimam as atividades humanas” (Schier, 2003, p.80).

$\mathrm{Na}$ geografia temos a paisagem natural e a paisagem cultural. Na paisagem natural estão ligados os elementos: relevo, solos, rios, vegetação; enquanto paisagem cultural inclui todas as modificações realizadas pela ação humana. Portanto, o estudo paisagem depende do enfoque, visando a definição em conjunto dos elementos envolvidos, da escala a ser utilizada e da temporalidade na paisagem. Em síntese, é a apresentação da paisagem em seu contexto geográfico e histórico, considerando as configurações sociais e os processos naturais e humanos (Schier, 2003, p.80).

O representante da geografia cultural contemporânea, Paul Claval, que na opinião de Schier (2003) atribui ao homem a responsabilidade de transformar a paisagem e destaca que diferentes grupos culturais são capazes de provocar transformações diferenciadas nela, criando assim, uma preocupação maior com os sistemas culturais do que com os próprios elementos físicos da paisagem. Ao concluir, o referido autor, argumenta que a paisagem é a realização e materialização de idéias dentro de determinados sistemas de significação. Assim, ela é "humanizada não apenas pela ação humana, mas igualmente pelo pensar. Cria-se a paisagem como representação cultural” (Schier, 2003, p.81).

Nos séculos 19 e 20, o termo paisagem era abordado como entidades espaciais relacionadas a história econômica, cultural e ideológica de cada sociedade. Ao considerar como portadoras de funções sociais, atuavam como processos capazes de "conferir ao espaço 
significados ideológicos, tendo como base, os padrões econômicos, políticos e culturais vigentes” (Schier, 2003, p.82).

Na Alemanha, durante a década de 60 (século 20), o estudo da paisagem partia do princípio que a paisagem representava um conjunto específico de relações ecológicas, com destaque aos fatores físicos. Foi Carl Troll, que em 1939, lançou as bases para o surgimento da corrente “ecologia da paisagem”. Nessa nova visão, os elementos da paisagem são agrupados segundo ponto de vista ecológico, “dividindo-os em ecótopos, unidades comparáveis aos ecossistemas”. Sendo assim, é introduzido o entendimento sistêmico das unidades geográficas (Schier, 2003, p.84). O alemão Carl Troll tinha como objetivo combinar a dimensão espacial, horizontal, da abordagem geográfica, com a dimensão verticalizada, da abordagem da ecologia (Maximiano, 2004, p.86).

A abordagem da geografia, através do estudo da paisagem não contempla todos os níveis, pois a complexidade da paisagem não permite uma análise geográfica segundo uma única abordagem. O estudo da paisagem física ou cultural exige uma visão mais ampla das questões geográficas. É necessária uma filtragem cultural, filosófica e política, que denota o carácter multidiciplinar no seu estudo (Schier, 2003, p.85).

A concepção geográfica de paisagem foi também analisada por Liz Maximiano (2004), que destacou o aspecto visual, resultante dos eventos naturais e sociais. No espaço, o interesse da geografia está relacionado à fisionomia e morfologia. Essa é uma característica que dá à paisagem, como objeto geográfico, a possibilidade de ser cartografada. Outro elemento citado é a escala, dando condição da hierarquia de classes de paisagem (Maximiano, 2004, p.88).

Visando evitar uma confusão entre os termos paisagem e espaço geográfico, podemos dizer que paisagem é a “materialidade congelada” e parcial do espaço geográfico Castillo (2002) apud Maximiano (2004, p.89). Sendo o espaço o objeto de estudo da geografia, podese dizer que a paisagem poderia ser definida como uma medida multidimensional de compreensão de um lugar (Maximiano, 2004, p.90).

O relevo e a paisagem designam conceitos usuais nos estudos da ciência geográfica. Esses termos, desde o princípio, tiveram suas raízes de elementos da natureza da geografia física. Podemos ter variadas definições de paisagem. O vocábulo se apresenta como um 
conceito chave da análise geográfica. Para o francês Georges Bertrand, o termo é pouco usado e impreciso, sendo um problema de ordem epistemológica. No entanto, o autor dá uma definição precisa, considerada clássica: “paisagem não é a simples adição de elementos geográficos disparatados. É, numa determinada porção do espaço, o resultado da combinação dinâmica, portanto estável, de elementos físicos, biológicos e antrópicos que, reagindo dialeticamente uns sobre os outros, fazem da paisagem um conjunto único e indissociável, em perpétua evolução (Bertrand, 1971).

O espaço, paisagem e unidade de paisagem são os três níveis importantes no estudo e na descrição do meio geográfico. A paisagem é algo concreto, palpável, diretamente perceptível no terreno, o resultado dos processos morfoclimáticos sucessivos que modelam e criam feições próprias do relevo (Ab Saber, 1969). Já para o alemão C. Sauer (1925), a paisagem é a interação do todo e é o campo da geografia. A paisagem emerge como uma paisagem natural, e a geografia se baseia na realidade, na união dos elementos físicos e culturais da paisagem.

De acordo com Bertrand (1971), o estudo da paisagem deve ser realizado dentro de um quadro de geografia física global. É utilizada pelo autor (op. cit.) a concepção de paisagem total, que inclui natureza mais ação antrópica. A essência da geografia é a delimitação dos espaços para entender a verticalização espacial. Para o entendimento exige-se uma espacialização. A delimitação é um recurso a mais na análise geográfica. Segundo Marcel Delpoux (1974), o termo paisagem denota um termo comum, apesar de ser uma expressão fundamental na geografia. O autor (op.cit.) considera que qualquer parte da superfície terrestre constitui uma paisagem, um setor ou um mosaico de paisagem.

Para finalizar, Monteiro (2000) dá sua contribuição sobre o termo paisagem, “entidade espacial delimitado segundo um nível de resolução do pesquisador, a partir dos objetivos centrais da análise, de qualquer modo, sempre resultante da integração dinâmica, portanto, instável, dos elementos de suporte e cobertura (físicos, biológicos e antrópicos), expressa em partes delimitáveis infinitivamente, mas individualizadas através das relações, que organizam um todo complexo (sistema), verdadeiro conjunto solidário e único, em perpétua evolução” (Monteiro, 2000, p. 39). 


\section{3 -Geomorfologia: definições e abordagens}

No dicionário geológico-geomorfológico, geomorfologia é compreendida como: "Ciência que estuda as formas do relevo, tendo em vista a origem, estrutura, natureza das rochas, o clima da região e as diferentes forças endógenas e exógenas que, de modo geral, entram como fatores construtores e destruidores do relevo terrestre” (Guerra, 1987, p.204). Para o Christofoletti (1980, p.1), a geomorfologia é a ciência que estuda as formas de relevo. Temos ainda uma definição que complementa de forma mais precisa, e diz: “(...) a geomorfologia como disciplina que estuda as formas do relevo quanto a sua geometria, gênese e idade, inclui-se no contexto das ciências da terra” (Ross, 2000, p.18).

O pesquisador Valter Casseti caracteriza “a geomorfologia como uma ciência que tem por objetivo analisar as formas de relevo, buscando compreender as relações processuais pretéritas e atuais”. Seu objeto de estudo é a superfície da crosta terrestre, (...) (Casseti, 1994, p.11). Pela origem etimológica, a palavra geomorfologia significa o estudo das formas da terra (geo - terra; morphos - forma; logos - estudo), (...) a geomorfologia preocupa-se com o aspecto genético das formas do relevo terrestre (Jatobá; Lins, 1995, p.11). Portanto, (...) “analisar e descrever as formas de relevo, identificando fenômenos significativos e determinando padrões de feições que podem se relacionar com a estrutura, com a drenagem, com a cobertura, e outras variáveis”. Essas características foram destacadas por Souza (2001, p.59).

Para dar suporte e status de ciência, é natural que em geomorfologia haja modelos de concepção teórica e metodológica, dando um fio condutor no ensino e na pesquisa. A abordagem e o enfoque nos estudos do relevo vêm-se aprimorando ao longo do tempo, visando, em última análise, a busca de um paradigma para a geomorfologia. Alguns autores, no Brasil, realizaram abordagem sobre a história evolutiva da ciência do relevo.

Abreu (1982), descreve a filogênese dos dois principais centros de origem dos sistemas conceituais da geomorfologia. A escola anglo-americana, estruturada basicamente no paradigma evolucionista. O grande expoente da corrente foi o geólogo William Moris Davis, com sua teoria do ciclo geográfico. A escola alemã, no entanto, apresentava uma concepção abrangente de ciências da terra, com uma perspectiva naturalista e globalizante. A teoria alemã foi estruturada pela contribuição de vários pesquisadores, o que permitiu uma evolução 
mais contínua, refletindo o enriquecimento gradativo do paradigma. Isso possibilitou a preservação de um núcleo comum desde sua origem (Abreu, 1982, p.8).

Na linhagem epistemológica alemã, o destaque foi Von Richthofen, como referência inicial, que teve como predecessores, os naturalistas Goethe e Humboldt (Abreu, 1982, p.12). Também contribuíram para a história evolutiva da ciência do relevo, os geógrafos Antônio Chistofoletti (1980), Valter Casseti (1994) e Jurandyr Ross (2000).

\section{4-As teorias geomorfológicas}

Ao longo da evolução da geomorfologia como ciência, várias teorias foram elaboradas por estudiosos, visando dar embasamento teórico a essa área do conhecimento. Christofoletti (1980) descreve as principais, citando a teoria do ciclo geográfico, o modelo da pedimentação e pediplanação, a teoria do equilíbrio dinâmico e a teoria probabilística.

O geólogo norte-americano William Morris Davis foi o principal expoente da corrente anglo-americana, que desenvolveu a concepção teórica do ciclo geográfico (1899) para a evolução do relevo. Para Davis, o relevo surgia em função da estrutura geológica, processos operantes e o tempo (aspecto histórico) (Abreu, 1982). A teoria davisiana é o primeiro modelo evolutivo, onde o relevo passa por sucessivos estágios desde a juventude, maturidade e senilidade (Christofoletti, 1980, p.60). O modelo teórico de Davis (1899) possui uma concepção finalista, onde todo o relevo tem começo, meio e fim, podendo recomeçar à juventude com o sorguimento de caráter tectônico (Ross, 2000, p 22).

No modelo de pedimentação e pediplanação, a principal contribuição foi de Lester King, que teve dupla influência, tanto do modelo de Davis como de Walter Penck. Para King, o relevo não tem um comportamento cíclico como preconizava o modelo teórico de Davis (Ross, 2000, p.25). O modelo de King diferenciava no modo como se processava a evolução das vertentes e nas pressuposições relacionadas ao nível de base (Chirstofoletti, 1980, p.165).

A teoria do equilíbrio dinâmico considera o modelado terrestre como um sistema aberto, que necessita constantemente de troca de matéria e energia com os demais componentes de seu universo. O primeiro a expor uma concepção teórica segundo os termos de equilíbrio dinâmico foi Gilbert, em 1880. Avançando nas pesquisas, Hack (1960) ampliou e deu nova abordagem à interpretação da paisagem, através do sistema de drenagem, iniciadas por Gilbert. Essa teoria supõe, que a atividade erosiva todos os elementos da topografia, 
estejam ajustados, permitindo que eles se alterem na mesma proporção (Chistofoletti, 1980, p.168).

A teoria probabilística prevê, em função da grande complexidade para se investigar a evolução do modelado terrestre que em amplas áreas, que ocorre grande variação na escala dos fenômenos atuantes na sua inter-relação que o conhecimento só avança por meio de propriedades médias, e que se utiliza de conceitos probabilísticos. A existência de inumeráveis fatores atuantes na evolução do modelado é a concepção básica dessa teoria. Essas teorias utilizam-se da linguagem matemática (Chistofoletti, 1980, p.171).

\section{5-A cartografia geomorfológica}

A geógrafa Teresa Cardoso da Silva, dá a sua visão ao apresentar os objetivos da cartografia geomorfológica: 'é a de representar em um mapa os resultados (síntese) da pesquisa geomorfológica e da sistematização dos dados relativos às formas de relevo da superfície terrestre, que possibilitam a explicação e as tendências de modificações dessas formas na dependência dos fluxos de energia internos e externos”(Silva, inf. verbal, 2004).

A cartografia geomorfológica permite a ligação dinâmica entre as ciências da terra e a ciências da vida. A pesquisadora (op.cit.), faz um balanço histórico da evolução da cartografia geomorfológica, descrito a seguir. É a partir de 1972, com a conferência de meio ambiente em Estocolmo, que ocorre a necessidade de agilizar a disciplina geomorfologia. Na década de 70 do século XX, houve um 'boom’ na cartografia geomorfológica na França e Alemanha, para encontrar uma metodologia para esse setor da geomorfologia. Para ela, a cartografia geomorfológica evolui nos anos de 1972, 1974 e 1975, depois desse período se 'acomodou' como os modelos.

A autora enumera os principais desafios a enfrentar em cartografia geomorfológica: a) método para enfrentamento da complexidade dos estudos e da representação; b) enfoques e abordagens diferenciadas dos estudos dos fatores, de domínio, de outras disciplinas; c) necessidade de elaborar uma taxonomia envolvendo as diversas ordens de grandeza do espaço-temporal a partir da classificação das formas de relevo; d) carência de uniformização das técnicas de sistematização e informatização dos dados e dos modos de representação cartográfica. Enfim, tornar a leitura e a compreensão dos mapas menos hermética, para que 
possa servir não somente aos geomorfólogos, mas também aos usuários de outras áreas, principalmente de gestores e planejadores (Silva, inf. verbal, 2004).

Vários estudiosos destacam a validade dos mapas geomorfológicos na área de ciências da terra. Demek (1977) esclarece que esse mapa, em geral, deve expressar as feições morfográficas e morfométricas das formas de relevo, sua gênese e idade. O autor (op.cit.) define como mapas geomorfológicos detalhados com escala de 1: 10000 e 1: 50000 (Demek, 1977, p.3). Nesses mapas, o autor cita que os conteúdos principais são as formas de relevo concretas e suas partes e que deveriam refletir a forma plástica do relevo e ser bem legível e ter informações em tão poucos, no máximo três ou quatro níveis (Demek, 1977, p.16).

Helmut Troppmair (1980) esclarece que a representação do relevo se faz por meio de uma simbologia, que é elaborada de modo a aproximar-se ao máximo às formas existentes no próprio espaço geográfico, que permita uma rápida interpretação morfográfica e morfométrica (Troppmair, 1980, p.100). A análise geomorfológica pode apresentar-se como resultado de pesquisa através do mapeamento geomorfológico ou ser uma fonte de informação para uma pesquisa.

Outro ponto a destacar sobre os mapas geomorfológicos é que se diferenciam dos demais tipos de mapas temáticos, tendo em vista a sua maior complexidade, pois devem apreender e representar uma realidade abstrata, ou seja, as formas de relevo, sua dinâmica e gênese (Ross, 2000, p.51). Portanto, o mapa geomorfológico é um importante instrumento de pesquisa do relevo. Tricart (1965) ensina que o mapa: “(...) constitui a base da pesquisa e não a concretização gráfica de pesquisa já feita”. 'Ele é ao mesmo tempo o instrumento que direciona a pesquisa e após conclusão, deve representar uma síntese como produto desta pesquisa’ (Ross, 2000, p.52).

A tendência na atualidade é de uma geomorfologia utilitária, cumprindo uma função social (aplicabilidade). Há uma grande demanda por estudos para as questões ambientais, para levantamentos dos potenciais dos recursos naturais (relevo), e a preocupação com as fragilidades e as limitações dos ambientes. Temos também, os estudos do uso das terras e das águas. O mapa geomorfológico é a linha mestra para a pesquisa. A própria construção desse mapa é considerado um produto de pesquisa (Ross, inf. verbal, 2004). 
O pesquisador polonês Meczyslam Klimaszewski destaca a importância da geografia ao afirmar: "toda sociedade, vive em um certo território, sob condições de um determinado ambiente geográfico. O ambiente forma a base e as ações do homem sobre a Terra. O conhecimento geográfico e seus elementos particulares é por conseguinte necessário por dominá-lo e utilizá-lo racionalmente. Além da estrutura, cobertura vegetal, clima, água e cobertura do solo, o relevo da superfície da Terra é especialmente, um elemento importante do ambiente” (Klimaszewski, 1982, p.1).

O autor citado descreve a evolução histórica da cartografia geomorfológica . Ele cita S. Passarge como o pioneiro na elaboração de um mapa geomorfológico de detalhe, em 1914. A elaboração do atlas morfológico composto por oito mapas, na escala 1: 50.000, detalhados a seguir: (1) mapa orográfico-topográfico com a cobertura vegetal; (2) mapa de gradientes de vertentes $\left(0-5^{\circ}, 5-10^{\circ}, 20-35^{\circ},>35^{\circ}\right)$; (3) mapa de formas de vales; (4) mapa geológico-estratigráfico; (5) mapa de resistência física; (6) mapa de resistência química; (7) mapa petrográfico e (8) mapa de desenvolvimento do relevo (Klimaszewski, 1982, p.2).

H. Gehne, em 1912, elaborou um mapa geomorfológico, dando informações sobre: feições morfológicas, estrutura do substrato e 'morfologia'- mostrando as formas de relevo e sua gênese. Durante o $18^{\circ}$ congresso da UGI, no Rio de Janeiro, em 1956, foram apresentados por H. Annaheim e M. Klimaszewski, dois conceitos para a elaboração de mapa geomorfológico de detalhe. Posteriormente, a subcomissão para mapeamento geomorfológico foi criada incumbida das seguintes atribuições: (a) introduzir na geomorfologia, o método de mapeamento de detalhe; (b) adotar um sistema uniforme e princípios de preparação de mapas geomorfológicos de detalhe, assegurando sua comparabilidade; (c) prover as economias nacionais de mapas geomorfológicos por ser um importante elemento do ambiente geográfico, facilitando a utilização racional da superfície da Terra. Esse mapa será usado no planejamento econômico, local e regional, em conjunto com os mapas geológico, hidrográfico, hidrogeológico, mesoclimático, paleológico e topográfico (Klimaszwki, 1982, p.3).

Na reunião da UGI, em Kracovia, em 1962, a subcomissão para mapeamento geomorfológico definiu os princípios básicos na elaboração de mapa geomorfológico de detalhe, enumerados a seguir: (1) um mapa geomorfológico de detalhe com controle de campo e com o uso de fotografias aéreas; (2) esses mapas compreendem as escalas de 1: 10 000 a 1: 100 000, (...); (3) os mapas devem apresentar visão completa do relevo, reconstituir 
seu passado e prognosticar tendências futuras. Os mapas devem ter informações morfográficas, morfométricas, morfogenéticas e morfocronológicas; (4) todas as formas pesquisadas devem ser plotadas em mapa por meio de símbolos em escala. Os símbolos e cores são de acordo como o tamanho, gênese e idade das formas; (5) a determinação de idades das formas é essencial, pois introduz a ordem cronológica no conteúdo do mapa e ajuda a prognosticar o desenvolvimento futuro; (6) dados litológicos devem ser marcados em símbolos especiais, no 'fundo do mapa'; (7) a legenda deve ser arranjada em uma ordem genético-cronológica e (8) o mapa geomorfológico é de grande valia na geomorfologia e no campo da geomorfologia regional, em vastas áreas territoriais com grandes variações climáticas e estruturais.

Segundo o autor (op.cit.), o mapa geomorfológico é de grande valor científico e prático. Avançando, ele destaca sua aplicabilidade em outras áreas do conhecimento, do mapa geomorfológico de detalhe, proporcionando uma exata e mensurável visão do relevo, dando informações a economia, tendendo a uma utilização mais racional das formas. A configuração da superfície da Terra é de maior interesse para a agricultura, assentamentos humanos, comunicações, hidrologia, turismo, recreação e para o manejo dos recursos (Klimaszewski, 1982, p.7).

Ao final de seu artigo, o pesquisador reafirma a utilidade do mapa geomorfológico de detalhe, para órgãos de economia e planejamento, destacando o seu valor científico, teórico e prático. Permite aos geomorfólogos que pesquisam e produzem mapa, uma visão geral de todas as formas, processos e fenômenos, sob duas perspectivas: do ponto de vista teórico e prático (Klimaszewski, 1982, p.10).

\section{6-Planejamento Ambiental}

A palavra planejamento expressa o significado empreendimento, projeto, intenção. A maioria dos planos é de caráter territorial criados no século 20. Esses planos tiveram uma concepção, com o domínio de visão positivista e progressista. Tais planos foram direcionados à obtenção do desenvolvimento econômico e de crescimento ilimitado (Franco, 2000, p.35).

Na década de 80 surgem novas modalidades de planejamento, orientados para as intervenções humanas dentro da capacidade de suporte de ecossistemas. Esse planejamento foi denominado de planejamento ambiental. Assim, podemos dizer, que esse conceito de 
planejamento parte do princípio da valoração e conservação das bases naturais em um dado território. É baseado na autosustentação da vida e das interações que mantém, ou seja, das relações ecossistêmicas (Franco, 2000, p.35).

Segundo a autora (op.cit.), o objetivo do planejamento ambiental é atingir o desenvolvimento sustentável da espécie humana e seus artefatos, representados pelo agroecossistemas e ecossistemas urbanos. O planejamento e o manejo ambientais podem ser definidos como o iniciar e a execução de atividades para dirigir e controlar a coleta, a transformação, a distribuição e a disposição dos recursos de forma sustentável das atividades humanas, nos processos físicos, ecológicos e sociais Baldwin (1985) apud Chistofoletti (1999, p. 162).

O planejamento ambiental envolve-se com os programas de utilização dos sistemas ambientais, como elemento condicionante de planos nas escalas espaciais do local, regional e nacional, no uso do solo urbano e rural, na execução de obras de engenharia e planejamento econômico (Chistofoletti, 1999, p.162).

Para Rosely Santos, o planejamento ambiental surgiu nas últimas décadas em razão do aumento dramático da competição por terras, águas, recursos energéticos e biológicos que gerou a necessidade de organizar o uso da terra. O objetivo é compatibilizar esses usos com a proteção de ambientes ameaçados e de melhorar a qualidade de vida das populações. Sendo assim, o planejamento ambiental é visto como uma solução de conflitos que pode ocorrer entre as metas de conservação ambiental e o planejamento tecnológico (Santos, 2004, p.27).

Outra visão concebe o planejamento ambiental ou territorial como uma atividade intelectual por meio da qual se analisam os fatores físicos-naturais, econômicos, sociológicos e políticos de uma zona (uma região, município, etc.) e se estabelecem as formas de uso do território e de seus recursos na área considerada Cendreno (1982) apud Botelho (1999, p.274).

Já o termo ordenamento territorial refere-se às etapas de estabelecimento e promulgação das normas de uso e suas aplicações derivadas do processo de planejamento (Botelho, 1999, p.275). A autora (op.cit.) enumera os fatores do meio físico como clima, geologia, relevo, solos, rede de drenagem e vegetação através do levantamento de dados visando conhecer as potencialidades e limitações de uso e ocupação de uma determinada área. 
O planejamento ambiental apresenta avanços na sua concepção teórico-metodológica em relação aos planejamentos regionais, municipais e urbanos, que tinham como meta o desenvolvimento econômico. O que caracteriza o planejamento ambiental é o seu caráter de princípio de capacidade de auto-sustentabilidade. Nesse sentido a auto-sustentabilidade deve alcançar todos os níveis de relações sócio-econômicas da população e dos vínculos mantidos pelos seres humanos com a natureza (Ross, 1998, p.384-385).

O planejamento ambiental, além do desenvolvimento econômico e social, envolve questões mais amplas relacionadas à natureza, através de suas potencialidades e de suas fragilidades. Um dos pressupostos básicos desse planejamento é na busca de soluções e meios visando obter a convivência harmônica entre natureza e sociedade. Assim, para ocorrer essa convivência racional, se faz necessário conhecer as potencialidades e as fragilidades dos ambientes naturais frente às atividades econômicas, que pode variar o nível de degradação, de acordo com o nível tecnológico usado.

Portanto, para cada ambiente natural é possível haver exploração econômica, compatível com a fragilidade e potencialidades. Nesse aspecto o elemento relevo, com suas formas e dinâmicas, tem significativa importância, junto com os demais componentes da natureza, como a água, o solo, a vegetação, as rochas e a fauna.

Todos os elementos bióticos e abióticos apresentam grande interação e a variável relevo funciona como indicador decisivo na natureza (Ross, 1998, p.385). Podemos destacar que o relevo está presente de forma concreta por meio das formas de diferentes tamanhos e gênese. Possui valor na identificação e no entendimento da funcionalidade dos ambientes naturais. Os estudos geomorfológicos são imprescindíveis nos estudos e diagnósticos elaborados, visando o planejamento ambiental a nível urbano, municipal e regional (Ross, 1998, p.386).

Jurandyr Ross (inf.verbal, 2004) apresenta sua concepção de planejamento ambiental, formado por bases técnicas/científicas e legal para a gestão ambiental. A base legal é representada pela legislação ambiental (leis federais, estaduais e municipais) e as áreas livres para atividades produtivas, que não são homogêneas (agricultura, pecuária, cidades e indústrias). São esses os parâmetros que se devem levar em consideração para fazer as análises das potencialidades e das fragilidades, definindo critérios de uso das terras ou dos 
recursos naturais. Com isso, obtêm-se o ordenamento territorial, que pode ser utilizado, com base no zoneamento econômico-ecológico (ZEE).

O zoneamento econômico-ecológico é instrumento para a gestão do território, que é elaborada através de análise, segundo uma abordagem geográfica. A aplicabilidade dos estudos do relevo tem papel primordial na análise integrada das variáveis da natureza/sociedade (questão jurídica, através da legislação). A análise integrada é estruturada pelo meio natural, sócio-econômico e base legal. No meio natural, temos os componentes: relevo, solos, água, vegetação e fauna, que atuam de forma integrada e interdependentes e formam uma unidade de paisagem ou geossistema, ou ainda uma unidade de terra. É a partir dessas análises, desses estudos que se avalia o potencial dos recursos naturais e suas fragilidades, com base territorial.

Nos aspectos sócio-econômicos são pesquisados o uso da terra e das águas, que é o reflexo da atividade econômica; é realizada a análise econômica, condições de vida e aspectos demográficos. Todas essas variáveis citadas envolvem a dinâmica histórica do lugar. Deve-se estudar a área e seu entorno (análise regional). Todas as informações coletadas e interpretadas serão utilizadas para a definição de paisagens culturais. A base legal é o espaço da legislação, fundamentada nos espaços demarcados pela legislação e unidades de paisagem. Em última instância é feita a proposta de zoneamento ecológico-econômico.

\section{7-A bacia hidrográfica como unidade de pesquisa}

No dicionário geológico-geomorfológico (1987) bacia hidrográfica significa “conjunto de terras drenadas, por um rio principal e seus afluentes” (Guerra,1987, p.48). Outra contribuição define “(...) a área da superfície terrestre drenada por um rio principal e seus tributários, sendo limitada pelos divisores de água” (Botelho, 1999, p.269). A bacia hidrográfica é uma componente da natureza que pode ser delimitada sobre uma base cartográfica, podendo ser vista através de uma visão tridimensional da paisagem.

Vários estudiosos destacam a bacia hidrográfica como unidade natural de análise da superfície terrestre, onde é possível reconhecer e estudar as inter-relações existentes entre os diversos elementos da paisagem e os processos que atuam na sua esculturação (op.cit.). Sendo assim, a bacia de drenagem representa uma unidade ideal de planejamento de uso das terras. 
As bacias hidrográficas possuem expressividade espacial, constituindo sistemas ambientais complexos em sua estrutura, funcionamento e evolução. As bacias de drenagem são unidades fundamentais para mensuração dos indicadores geomorfológicos, para a análise da sustentabilidade ambiental baseada nas características do geossistema e o elemento sócioeconômico (Chistofoletti, 1999, p.173).

A bacia hidrográfica é destacada por Celeste R. Maio (1983) no estudo da percepção, da estrutura das paisagens e suas relações ambientais, onde as dimensões de suas propriedades morfológicas podem extrapolar as da sua própria área (Maio, 1983, p.182).

O estudo da rede hidrográfica, suas nascentes, padrão, densidade, tipos de canais fluviais, velocidade, entre outros parâmetros, permitem avaliar tipos de usos da água até o estado de degradação das terras (...) (Botelho, 1999, p.282). Para a autora (op.cit.) (...) o arranjo da rede de drenagem é o reflexo de um conjunto de variáveis físicas, como o clima, relevo, solos, substratos rochosos e vegetação. A grande diversidade de uso da terra interfere no ciclo hidrológico, não importando o grau de utilização ou dependência direta da água. A abordagem integrada tem sido recomendada para resolver os problemas que envolvem os recursos hídricos.

As unidades ambientais baseadas no estudo da paisagem (unidades geossistêmicas), permitem uma análise integrada dos diversos elementos que compõem o quadro regional, porém apresentam problemas na sua delimitação, dada a dinamicidade dos elementos envolvidos. Outras unidades podem ser distinguidas, por meio das delimitações baseadas em fatores topográficos como é o caso das bacias hidrográficas. Estas correspondem a unidades naturais que espelham a dinâmica de um sistema aberto cujos limites são, de modo geral, fáceis de identificar. Neste sistema, bastante complexo, verifica-se uma interdependência entre suas partes componentes.

O conceito tradicional de planejamento de bacias hidrográficas se refere basicamente ao planejamento do uso dos recursos hídricos para projetos de aproveitamento de energia hidrelétrica, de controle de enchentes, irrigação e outros.

Dada a diversidade de características ambientais inscritas numa bacia hidrográfica, e objetivando bases mais consistentes para o planejamento ambiental, Silva (1978) propõe com 
base espacial unidades topográficas individualizadas da bacia hidrográfica, cujas características geomorfológicas expressem de forma integrada a dinâmica ambiental.

Ross; Del Prette (1998) discutem a gestão dos recursos hídricos em um contexto de planejamento ambiental. Abordam alguns aspectos do planejamento e da política ambiental no Brasil, mostrando sua evolução. Os autores citam como instrumentos legais para o gerenciamento dos usos múltiplos da água de superfície, o Código de Águas de 1934 e o Código Florestal de 1965. Informam esses mesmos autores que predominaram no Brasil, até o final da década 1960, ações pontuais e isoladas nas questões ambientais, por parte do poder público. A tendência e os objetivos foram em busca do crescimento econômico com base no aumento da exploração dos recursos naturais e do avanço tecnológico, pós $2^{\mathrm{a}}$ Guerra Mundial (Ross; Del Prette, 1998, p.91).

Com a criação do Ministério do Meio Ambiente em 1993, a “administração das águas deixa de ser um aspecto setorial de produção de energia e passa a incorporar os usos múltiplos, dentro de um contexto mais abrangente de gestão ambiental” (Ross; Del Prette, 1998, p.94). Os autores argumentam que os problemas nacionais devem estar inseridos nas questões de planejamento estratégico, de desenvolvimento econômico e em destaque as grandes questões nacionais.

Em resumo, falta uma política de desenvolvimento econômico e social para o país. As questões ambientais não podem ser tratadas de forma isolada e fora dos contextos econômicos e sociais. Mesmo os avanços da legislação ambiental e de órgãos ligados a gestão ambiental, não garantem o respeito às normas. As áreas de proteção ambiental, as terras públicas e terrenos privados têm sido constantemente ocupados por empresas particulares, com interesses econômicos ou por grupo de pessoas de baixa renda, que fazem moradias, em áreas de preservação ambiental (Ross; Del Prette, 1998, p.98).

Pode-se acrescentar, nessa mesma linha, algumas considerações, na pesquisa realizada sobre os problemas ambientais de área de proteção aos mananciais da região metropolitana de São Paulo, que diz: “Os ideais de preservação ambiental com justiça social devem ser compatíveis com o desenvolvimento urbano. Nesse sentido, o planejamento (regional e local), baseado na potencialidade do ambiente natural e sócio-econômico, assume importância fundamental na ordenação do espaço territorial, no aproveitamento dos recursos 
hídricos. E sua exiguidade será maior e melhor, desde que os planos sejam frutos da integração de conhecimentos e interesses de todas as forças atuantes na sociedade” (Moroz; Kanil; Ross, 1994, p.47).

Atualmente, a água como recurso natural tem papel destacado na sociedade. Por isso, a bacia hidrográfica é utilizada com freqüência como referencial geográfico para adoção de práticas de planejamento ambiental e aproveitamento de recursos naturais (Ross; Del Prette, 1998, p.102). Os autores (op.cit.) dizem que o futuro da gestão ambiental deve tornar as bacias hidrográficas como Unidades de Planejamento Regional, com destaque à questão dos recursos hídricos. Essa nova visão deve contemplar todos os componentes dos recursos naturais (águas, solos, relevo, subsolo, flora e fauna) e as componentes sociais e econômicas, inseridas no contexto regional e sua articulação com os problemas nacionais.

Nessa perspectiva, os avanços do gerenciamento ambiental devem ir além da atuação dos comitês de bacia, rompendo a ótica dos recursos hídricos. "Neste sentido, as proposições de gestão ambiental e de recursos hídricos precisam atender a perspectiva multisetorial e multitemática, visando a definir uma base institucional segura na administração dos problemas” (Ross; Del Prette, 1998, p.119).

\section{8-Zoneamento Ambiental}

Pode-se definir zoneamento, como sendo a compartimentação de uma região ou porções territoriais obtidas através da avaliação de atributos mais significativos e de suas dinâmicas. Assim, cada compartimento representa uma “área homogênea” nos aspectos da estrutura e funcionamento e é delimitada no espaço. Outra contribuição, diz que zoneamento ambiental é “ a expressão cartográfica de uma organização ecológica paisagística do espaço, que visa o uso eficiente dos recursos edáficos, biológicos, hídricos e climáticos dos ecossistemas naturais e modificados pelo homem” Sanches (1992) apud Silva (2002, p.10). Para o primeiro autor (op.cit.), o significado de zonear é um termo geográfico que representa desagregar um espaço em zonas ou áreas específicas. Para realizar o zoneamento é necessário o conhecimento da realidade do espaço geográfico e as especificidades dos elementos do meio físico e da sociedade.

Vários autores procuraram definir e destacar a importância do zoneamento ambiental. Clark (1974) apud Silva (2002, p.11) explica que “o zoneamento ambiental é uma forma de 
registro dos condicionantes ambientais de uma área, visando sua proteção ou utilização racional”. O zoneamento ambiental é uma forma de espacialização da questão ambiental, de acordo com as dimensões naturais e sócio-econômicas, que reflete nos níveis de preservação ou de degradação do meio físico e social. É considerada uma ferramenta a ser utilizada com objetivos de prevenir, controlar e monitorar os impactos ambientais e as repercussões na sociedade (Silva, 1993) apud Silva (2002, p.11).

Para Santos (2004) o zoneamento é uma atividade interdisciplinar com domínio qualitativo e de análise quantitativo, segundo um enfoque analítico e sistêmico. O enfoque analítico é definido por levantamentos dos principais temas. Já o enfoque sistêmico é baseado na integração dos temas e aplicação dos critérios, resultando uma síntese do conjunto de informações (Santos, 2004, p.133). A autora (op.cit.) acrescenta que em planejamento ambiental, as zonas costumam expressar as potencialidades, fragilidades, acertos e conflitos de um território. Geralmente, o resultado do zoneamento é apresentado em forma de mapa. Cada unidade definida no zoneamento possui normas específicas, visando o desenvolvimento de atividades e de conservação do meio físico.

O zoneamento ambiental procura ordenar o território, segundo as características bióticas e abióticas, por meio de agrupamento de áreas cujos conjuntos, define unidades de terra, com certo grau de homogeneidade, contribuindo para análise integrada da paisagem Cassol (1996) apud Silva (2002, p.11).

Na contribuição de Wendel Henrique (2000), o autor procura enfatizar o uso do zoneamento ambiental como instrumento de planejamento, antevendo o processo de ocupação humana de uma região. O autor destaca que “o zoneamento ambiental é uma prática que deveria ser empregada antecipadamente no controle e direção da ocupação do território, principalmente na questão urbana, a qual concentra uma gama enorme de impactos ambientais negativos no meio ambiente” (Henrique, 2000, p.90).

O zoneamento ambiental é considerado um excelente instrumento de gestão, sendo que as zonas definidas como espaços de administração, manejo e proteção dos valores naturais e sociais. A pesquisadora (op. cit.) destaca ainda o equívoco de considerar sinônimos os termos planejamento e zoneamento. O “zoneamento é uma estratégia metodológica que representa uma etapa de planejamento” (Santos, 2004, p.133). O zoneamento objetiva definir 
espaços segundo critérios pré-estabelecidos, enquanto o planejamento define diretrizes e metas a serem alcançadas dentro de certo tempo para os espaços delimitados. O zoneamento geoambiental é baseado na teoria de sistemas.

Segundo Ross (1995), o referencial inicial dos estudos ambientais de âmbito geográfico é a sociedade que vive em um determinado território, onde exerce atividades que variam com maior ou menor grau de complexidade, relacionadas a fatores internos e externos que mantém a nível cultural, social e econômico (Ross, 1995, p.66). A pesquisa ambiental a nível geográfico permite realizar diagnósticos sócio-ambientais, dando condições na elaboração dos prognósticos. Assim sendo, as análise ambientais tornam-se “excelentes suportes técnico-científicos para a elaboração dos zoneamentos ambientais e sócioeconômicos”, dando condições na formulação de políticas de planejamentos estratégicos. Essas políticas de planejamento poderão ser utilizadas em qualquer nível de gerenciamento no território, como por exemplo, no país, estados, municípios, áreas metropolitanas e bacias hidrográficas (op.cit.).

Os estudos ambientais devem ter a contribuição de várias ciências, visando compor um sistema de informações geográficas aplicadas no planejamento ambiental. Os "estudos (diagnósticos) e as proposições (prognósticos) devem ser produzidos por equipes multidisciplinares. Deve haver significativa contribuição mútua (integração entre os produtos temáticos gerados” (Ross, 1995, p.68).

Ross (1995) cita na área de geociências, as seguintes disciplinas: geologia, geomorfologia, climatologia, pedologia e recursos hídricos. O campo da biociência envolve pesquisa da flora e fauna. São consideradas componentes naturais muito sensíveis e vulneráveis à ação humana. São dependentes de fluxo energético da litosfera, da atmosfera e hidrosfera (Ross, 1995, p.70). Na área de ciências humanas (história, economia, ciências sociais), o planejamento ambiental tem como centro de atenção o homem, como ser social. O planejamento tem como propósito melhorar a apropriação de recursos naturais através da utilização racional que permitirá a exploração não predatória dos bens da natureza.

Em seu trabalho Ross (1995) descreve os produtos de sínteses, gerados a partir de análises integradas. O autor cita cinco produtos cartográficos acompanhados de textos, baseado nas três áreas básicas do conhecimento: o físico, o biótico e o sócio-econômico. Os 
cinco produtos gerados são denominados de: unidades dos sistemas naturais; unidade dos sistemas sócio-econômicos, unidades integradas dos sistemas naturais e sócio-econômicos; unidades das fragilidades potenciais e emergentes e por último, o das derivações ambientais e transgressões legais (Ross, 1995, p.70). A concepção teórica utilizada nos trabalhos dessa abordagem, deriva da teoria dos sistemas.

A seguir são descritas as cinco unidades citadas acima:

A- Unidade de Sistemas Naturais - são espaços territoriais que apresentam um certo grau de homogeneidade fisionômica. Na paisagem, os elementos mais significativos vistos pela visão do homem são o relevo e a vegetação. É através das fotografias aéreas e de imagens de satélites é revelado a rugosidade topográfica dada pelo relevo e pela cobertura vegetal. Portanto, “a combinação destas duas variáveis permite a distinção de diferentes padrões fisionômicos. Apesar de aparecer como um 'retrato' estático da paisagem, seus elementos, como as rochas, os solos, o ar e as águas, são na realidade dinâmicos e quase invisíveis, mas mensurável através de técnicas de campo e laboratório” (Ross, 1995,p.71). Todo esse dinamismo é evidenciado por meio de trocas de energia e matéria entre os componentes da natureza.

B- Unidade dos Sistemas Sócio-Econômicos - As diferentes formas de apropriação dos recursos naturais pelo homem produzem diferentes cenários na organização espacial do território. Os tipos de uso da terra refletem "um retrato estático da manifestação dinâmica das relações sócio-econômicas daquele território”. A identificação das unidades sócio-econômicas se faz pelo uso da terra e das relações sociais e econômicas que se estabelecem entre os homens em um determinado lugar. Outros dados podem ser levantados como a estrutura agrária, tipos de relações de trabalho, o grau de tecnologia e de manejo do solo (Ross, 1995, p.72).

C- Unidades Integradas dos Sistemas Naturais e Sócio-Econômicos - São associações entre o contexto das unidades dos sistemas naturais com o das unidades sócio-econômicas. O produto resultante fornece um retrato estático ou “cenário atual” dos fluxos das relações sociedadenatureza (op.cit.). Tais cenários podem ser metas de um reordenamento territorial, através da adoção de políticas de planejamento, utilizando um dos instrumentos básicos de gestão disponíveis, que é o zoneamento ambiental-sócio-econômico. 
D- Derivações Ambientais e Transgressões Legais - trata-se de uma síntese de análise integrada do meio físico, biótico e sócio-econômico e da legislação ambiental. O objetivo é estabelecer um padrão de qualidade ambiental global, representado por um mapa síntese. Este produto tem o objetivo de revelar os conflitos entre os usos inadequados dos recursos naturais, conflitos entre os diferentes tipos de usos dos recursos e também entre os usos e a legislação ambiental (op.cit.).

E- Unidades de Fragilidades Naturais - Este estudo identifica e analisa os ambientes em função de seus diferentes níveis de fragilidades, através da identificação das fragilidades potencias e emergentes dos ambientes naturais. Dão subsídios à definição de diretrizes e ações a serem implementadas no espaço físico territorial (Ross, 1995, p.73).

Na definição de áreas que apresentam graus de fragilidade mais baixo ou menos elevado, irão compor informações dos componentes da natureza de forma integrada. Portanto, “os produtos cartográficos devem representar os diferentes ambientes naturais, as suas fragilidades potenciais e emergentes e as áreas de riscos (riscos a deslizamentos, inundação, entre outros)” (Ross, 1995, p.73). A escala de análise é primordial, ou seja, quanto maior a escala, melhor será o grau de detalhamento dos resultados.

Através da definição de unidades ecodinâmicas elaborada por Tricart (1977), foram definidas as fragilidades dos ambientes naturais. Esse autor definiu que os ambientes em equilíbrio dinâmico são estáveis e em desequilíbrio são instáveis. Visando aperfeiçoar essa abordagem, Ross (1990, 1994) apresentou novos critérios para definir as unidades ecodinâmicas estáveis e unidades ecodinâmicas instáveis. Assim, foram propostas as unidades instáveis ou de instabilidade emergente, em diferentes níveis, variando de instabilidade muito fraca a muito forte. Aplicou o mesmo princípio para as unidades ecodinâmicas estáveis, passando a denominar de unidades ecodinâmicas de instabilidade potencial, em diferentes graus, ou seja, de muito fraca a muito forte. 


\section{5- PROCEDIMENTOS TÉCNICOS}

Silva (1978) mostrou que as subdivisões ambientais poderiam, com mais propriedades, ser geradas com base na geomorfologia da área e que as unidades de manejo ambiental assim determinadas seriam “ os conjuntos ambientais naturalmente estruturados, capazes de fornecer um fundamento adequado para as previsões imprescindíveis ao planejamento regional”.

A identificação e a classificação das unidades ambientais serão realizadas, considerando-se as características geomorfológicas, cartográficas, e de sensoriamento remoto, com apoio de campo e literatura especializada. O trabalho será desenvolvido em vários estágios, conforme o fluxograma de atividades e produtos, figura 2.

\section{1-Levantamento bibliográfico e cartográfico}

Foi realizado levantamento bibliográfico de trabalhos desenvolvidos na área e dos assuntos pertinentes. As etapas de trabalho iniciaram com a coleta de dados e consulta bibliográfica, visando a elaboração da fundamentação teórica-metodológica. Foram levantados os dados disponíveis referentes a área de pesquisa, material cartográfico, fotografias aéreas, etc.

Compartimentação topográfica que levará em conta:

a) distribuição geográfica de conjuntos de formas de relevo que caracterizam vales e divisores de drenagem identificáveis com base em fotografias aéreas de 1978 na escala 1: 45.000, em vôo realizado pela empresa Aerofoto Cruzeiro. Tais fotos pertencem a Secretaria Planejamento, Orçamento e Gestão do estado de Santa Catarina.

b) análise hipsométrica, através de níveis observáveis em cartas topográficas editadas pelo IBGE, escala 1: 50.000, das folhas de Florianópolis (Folha SG-22-Z-D-V-2)(MI-2909/2), Biguaçu (Folha SG-22-Z-D-II-4), São João Batista (Folha SG-22-Z-D-II-3) e Santo Amaro da Imperatriz (Folha SG-22-Z-D-V-1).

\section{2-Procedimentos Técnicos Adotados}

O primeiro procedimento adotado consistiu na digitalização da base cartográfica. Foram utilizadas cartas topográficas na escala 1: 50000 do IBGE, referentes às folhas: Biguaçu, Florianópolis, São João Batista e Santo Amaro da Imperatriz. A digitação foi feita utilizando o programa AUTO CAD R14. As informações de drenagem, estradas, limite da 
bacia, curvas de nível e pontos cotados foram digitalizadas em forma de Planos de Informações (PIs). Após o término da digitalização, os PIs foram exportados para o ILWIS e editados segundo os seguintes modelos: categoria de classe para os PIs drenagem, estradas e limite da bacia, categoria numérico para as curvas de nível e pontos cotados.

\section{Digitalização dos Mapas Temáticos}

A digitalização dos mapas temáticos (geologia, unidades do relevo, solos e cobertura e uso da terra) foi feita de forma semelhante à base cartográfica. O AUTO CAD foi utilizado para a digitalização dos limites de cada mapa. Em seguida, os limites foram importados para o ILWIS e editados para a categoria de classe. Utilizando uma ferramenta denominada de “check segment”, todos os arquivos foram corrigidos em relação à consistência topológica. Posteriormente, os seguimentos foram convertidos para polígono, utilizando um algorítmo de conversão segmento-polígono (Tomlin, 1990).

\section{Modelo Numérico do Terreno}

O modelo numérico do terreno (MNT) consiste numa das principais técnicas computacionais utilizadas para a geração de cartas, como declividade do terreno (conhecida como carta clinográfica), orientação das vertentes, hipsometria, modelos 3D etc.

A partir das curvas de nível e pontos cotados que foram digitalizados (categoria numérica) foi elaborado o MNT. O método de interpolação implementado no ILWIS baseiase num modelo de grade regular retangular, conhecido como distância de Borgefor (Gorte; Koolhoven, 1990). Trata-se de um método de interpolação linear que se divide em duas etapas. Primeiro é feita a conversão das curvas de nível (em formato vetorial) para o formato matricial (rasterização das curvas de nível). Posteriormente, estimam-se os valores nos locais não amostrados baseando-se na menor distância do pixel estimado em relação às curvas de nível (Burrough, 1986).

Com base no MNT foram gerados os mapas hipsométricos e clinográficos. Os intervalos adotados foram: 1- 0 metros a 20 metros; 2- 20m a $100 \mathrm{~m}$; 3- $100 \mathrm{~m}$ a $200 \mathrm{~m}$; 4200m a 400m; 5- 400m a 600m; 6- 600m a 880m, no mapa hipsométrico. Para o mapa clinográfico foram adotados os intervalos: A- 0\% a 3\%; B- 3\% a 6\%; C- 6\% a 12\%; D- 12\% a $20 \%$; E- 20\% a 30\%; F- >30\%. 
Mapa de distância dos rios e cabeceiras

A área de preservação permanente (APP) que protege os rios e cabeceiras foi mapeada com auxílio da técnica de análise de distância ou buffer. O arquivo de drenagem digitalizado da base cartográfica (PI drenagem) foi utilizado como PI de entrada para a delimitação das faixas de proteções. Para a delimitação do entorno das cabeceiras foi necessária a criação de um arquivo, contendo para cada cabeceira um ponto. Em seguida, foi calculada a distância que corresponde à zona de proteção.

Mapa de Fragilidade Ambiental

O mapa de fragilidade ambiental foi elaborado combinando a declividade do terreno com os tipos de solos encontrados na bacia. A combinação foi feita utilizando uma técnica de análise espacial denominada tabela bidimensional, também conhecida como tabela de dupla entrada. Essa tabela permite ao usuário definir a forma como todas as classes de dois mapas podem ser combinadas, resultando num terceiro mapa que guarda as características estabelecidas pela interseção tabulada.

Segundo Boham-Carter (1994), a tabela bidimensional pode ser entendida como um tipo de função de reclassificação, que converte um mapa de entrada por meio de uma tabela que registra a nova classe do mapa de saída. O primeiro procedimento na construção desta tabela consiste na padronização dos mapas temáticos para um mesmo tipo de estrutura. No ILWIS, os mapas de entrada precisam ser convertidos para o formato raster, utilizando a mesma georeferência (tamanho de pixel e área envolvente). Em seguida, os mapas são tabulados, conforme a metodologia de Ross (1994).

\section{Mapa de Zoneamento Ambiental}

O mapa de zoneamento ambiental foi elaborado combinando as informações de fragilidade do terreno com os mapas de legislação ambiental (APP, capoeirões, capoeiras, manguezal e RPPN), cobertura e uso da terra e declividade do terreno. Além da tabela bidimensional foram utilizadas máscaras espaciais para a sobreposição dos temas. 


\section{3-Mapas Temáticos Produzidos}

\subsection{1-Mapa Hipsométrico}

É o mapa que representa o terreno em termos de altitudes, acima de um plano de referência, em cores (Oliveira, 1983, p.400). Foi elaborado a partir do mapa base da bacia do rio Biguaçu, em meio digital. Foram definidas as seguintes classes: 1- 0m a 20m; 2- 20m a 100m; 3- $100 \mathrm{~m}$ a $200 \mathrm{~m}$; 4- 200m a $400 \mathrm{~m}$; 5- 400m a $600 \mathrm{~m}$; 6- $600 \mathrm{~m}$ a $800 \mathrm{~m}$; 7- 800 a 900 metros. O produto final foi elaborado na escala 1: 50.000.

\subsection{2-Mapa Clinográfico}

Elaborado em porcentagem, segundo partes das quatro cartas topográficas que abrangem a da bacia do rio Biguaçu (folhas do IBGE: Florianópolis, Biguaçu, Santo Amaro da Imperatriz e São João Batista), elaborado por meio da cartografia digital. A legenda elaborada é a seguinte: A- 0\% a 3\%\%; B- 3\% a 6\%; C- 6\% a 12\%; D- $12 \%$ a 20\%; E- 20\% a 30\%; F- >30\%. O mapa gerado está na escala a 1: 50.000 .

\subsection{3-Mapa Geológico}

Foi elaborado tendo como base o mapeamento de Trainini et ali (1978) modificado e complementado por Fortes (1996), que elaborou o mapa de geologia da bacia do rio Biguaçu na escala 1:50.000. Esse mapa foi adequado aos objetivos de pesquisa e transferidas suas informações para uma base digital.

\subsection{4-Mapa de Solos}

Esse mapa terá como base o Projeto de Gerenciamento Costeiro do estado de Santa Catarina (GERCO), executado pelo Digeo-Sul do IBGE, para a Secretaria de Planejamento do estado de Santa Catarina. A área de estudo compreende a $2^{a}$ fase (1995) e $3^{a}$ fase (2003), do referido projeto, na escala original 1: 100.000. Esse mapa foi modificado e adaptado, visando atender aos objetivos e a escala da pesquisa, cuja escala é de 1: 50.000 e posteriormente digitalizado para o meio digital.

\subsection{5-Mapa de Unidades do Relevo}

Foi elaborado com base em imagens de satélite Landsat 7, sensor ETM+, bandas 3, 4 e 5 e pancromática, com órbita da imagem, ponto 220/79, com data de 7 de maio de 2000. Aquisição da imagem na Globaland Cover, com o processamento da imagem no dia 25 de 
maio e $1^{\circ}$ de junho de 2005, no Laboratório de Sensoriamento Remoto, do departamento de Geografia, da FFLCH, da USP. O processamento da imagem baseou-se no processamento digital de imagem de sensoriamento remoto, de acordo com a proposta de Álvaro Crósta (1993). A imagem colorida apresenta 15 metros de resolução na escala 1: 50.000.

Foi gerada uma imagem, sendo georeferenciada, com os planos de informações de estradas e de drenagem, de acordo com base cartográfica digital da bacia. Nessa tarefa, foi necessário o conhecimento geográfico da realidade, obtido através de trabalhos de campo. O mapa de Unidades do Relevo, na escala 1: 50.000, segue a proposta metodológica de Ross (1992). O mapa foi feito de acordo com os objetivos da pesquisa e a limitação da escala da imagem de satélite. Foram definidas cinco unidades do relevo da bacia do rio Biguaçu.

\subsection{6-Mapa de Ocupação e Uso da Terra - 2006}

Foi elaborado com base em fotografias aéreas de 1978, da Aerofoto Cruzeiro, na escala 1: 45.000. Foi realizado controle de campo e atualizações da ocupação e uso da terra em toda a bacia do rio Biguaçu. O mapa de ocupação e uso da terra atual foi produzido na escala 1: 50.000 .

\subsection{7-Mapa de Fragilidade Ambiental}

Foi elaborado segundo a metodologia de fragilidade dos ambientes naturais e antropizados de Ross (1994). Foram representadas no mapa as informações espaciais referentes à fragilidade à erosão e fragilidade à inundação da bacia do rio Biguaçu. A edição final do mapa foi reproduzida no papel A-3, na escala 1: 100.000.

\subsection{8-Mapa de Legislação Ambiental}

Este mapa teve como base o mapa de ocupação e uso da terra 2006, onde as informações espaciais de ocupação de capoeirões, capoeiras, manguezal, RPPN e terras com agricultura e pecuária, bem como, manchas urbanas. Baseado no Código Florestal Brasileiro foi plotado na rede de drenagem, a faixa de proteção de área de preservação permanente (APP), com distâncias de 30 metros, 50 metros, 100 metros e canais de cabeceiras com 50 metros. 


\subsection{9-Mapa de Zoneamento Ambiental}

Este mapa representa a combinação de vários mapas temáticos: clinográfico, ocupação e uso da terra 2006, legislação ambiental, unidades de relevo. Foram definidas as zonas de restrições legais e as zonas produtivas da bacia do rio Biguaçu.

\section{4-Medição de vazão do rio Biguaçu}

A definição de vazão: “a medição de vazão em hidrometria é todo o processo empírico utilizado para determinar a vazão de um curso d’água. A vazão ou descarga de um rio é o volume que passa através de uma seção transversal na unidade de tempo” (Santos et al., 2001, p.119).

O método utilizado na medição de vazão envolve algumas grandezas características do escoamento na seção. São grandezas geométricas da seção: área, perímetro molhado, largura, profundidade. No escoamento são relacionadas às grandezas, velocidade e vazão.

As coordenadas de posicionamento mais usuais são referidas a uma linha reta que une dois pontos fixos nas margens PI (ponto inicial) e PF (ponto final) e a distância vertical contada a partir da superfície livre (op. cit., p.120). É atribuída ao plano de referência par a cota do nível da água, geralmente é o zero da régua linimétrica no local.

Santos et al.(2001) dá algumas recomendações para a realização de medição direta de vazão, descritas a seguir. O local escolhido deve ser desprovido de obstáculo no fundo (bancos de areia, blocos de rochas) e nas margens. É importante situar-se em um trecho retilíneo do rio, dando condições na distribuição de velocidades paralelas em toda a seção, sem variações bruscas. Na medição da vazão a distância entre verticais irá depender da largura do rio e da regularidade de escoamento. As distâncias entre verticais foram com base no DNAEE (1967), apud Santos (2001, p.142), conforme tabela abaixo. 
Tabela 1 - Distância recomendada entre verticais em função da largura do rio.

\begin{tabular}{|c|c|}
\hline Largura do rio (metros) & Distância entre verticais (metros) \\
\hline$<3,00$ & 0,30 \\
\hline $3,00-6,00$ & 0,50 \\
\hline $6,00-15,00$ & 1,00 \\
\hline $15,00-30,00$ & 2,00 \\
\hline $30,00-50,00$ & 3,00 \\
\hline $50,00-80,00$ & 4,00 \\
\hline $150,00-150,00$ & 6,00 \\
\hline$>250,00$ & 8,00 \\
\hline
\end{tabular}

Fonte: Dnaee (1967) apud Santos et al. (2001, p.142).

Na medição de vazão do rio Biguaçu foram escolhidas duas seções, levantadas durante trabalho de campo. A $1^{\text {a }}$ seção estava a montante da foz do rio Três Riachos, utilizou-se da distância de 1,00 metro entre as verticais. Na $2^{\mathrm{a}}$ seção, próxima à foz do rio Biguaçu, a distância entre as verticais foi de 2,00 metros. Para a medição foi utilizada uma corda de segurança com 85,00 metros de comprimento, graduada de 1,00 em 1,00 metro. A medição teve início na margem direita do rio. Para a fixação da corda de margem a margem, acima do nível da água, foi usada uma bateira. Na medição da profundidade do rio foi usada uma trena fixada em uma vara de bambu.

Foram realizadas medidas no inverno (julho/2005) e verão (fevereiro/2006). Para o cálculo da velocidade da corrente foi utilizada a medição com flutuador. Foi estendida na margem direita do rio Biguaçu, no ponto inicial (PI), uma trena náutica. Foi seguida a recomendação técnica de medir o deslocamento do flutuador em uma distância de 10 metros.

Para o cálculo das áreas dos segmentos, foi usado o método da seção média:

$$
\mathrm{A} 1=\mathrm{d} 2-\mathrm{d} 1(\mathrm{p} 2+\mathrm{p} 1)
$$

\subsection{1-Medição com flutuadores}

Esse método consiste em determinar a velocidade de deslocamento de um objeto flutuante, medindo o tempo utilizado para o seu deslocamento num determinado trecho de rio de comprimento conhecido (Santos et al., 2001, p.196). Normalmente se utiliza desse método 
quando não há disponível no momento, molinete e ou outros equipamentos necessários a realização de vazão líquida por processos mais precisos.

No flutuador de superfície usado na medição de vazão do rio Biguaçu foi utilizada uma garrafa plástica (pet) de $500 \mathrm{ml}$ (sem rótulo). Um flutuador de superfície é projetado para mover-se com a mesma velocidade da superfície da água, sendo muito leve, pode sofrer a influência do vento. Como o flutuador indica apenas a velocidade da superfície da água, é necessário aplicar um coeficiente redutor para obter a velocidade média na seção (op. cit.).

Santos et al. (2001) avalia "como processo expedito, no caso de avaliações preliminares de vazão pode ser bastante útil” (Santos et al. 2001, p.197). Para a obtenção de dados pelo método de flutuadores, deve-se seguir as mesmas recomendações já citadas anteriormente. A escolha do trecho retilíneo, com margens paralelas, comprimento mínimo de duas vezes a sua largura e ter boa visibilidade.

\subsection{2-Cálculo de vazão}

Para o cálculo da vazão do rio, temos a fórmula:

$$
\mathrm{Q}=\mathrm{c} \times \mathrm{S} \times \mathrm{V} \text {, }
$$

sendo $\mathrm{Q}=$ vazão em m³/s; $\mathrm{S}$ = área da seção; $\mathrm{V}=$ velocidade do fluxo; c = coeficiente de correção para valor real.

O método de flutuador só funciona para rios de maior vazão e boa profundidade (Valente; Gomes, 2005, p.85). Os autores (op.cit.) explicam que na medição de velocidade, a garrafa deve estar cheia o suficiente para ficar 2/3 de sua altura dentro da água. No caso do rio Biguaçu, o lançamento da garrafa foi sempre acima da seção, com o apoio da bateira. Essa operação foi realizada de três a cinco vezes e usando a média das velocidades encontradas. O coeficiente de correção usado na medição de vazão com flutuador foi o valor médio de 0,75 (Valente; Gomes, 2005, p.87). 


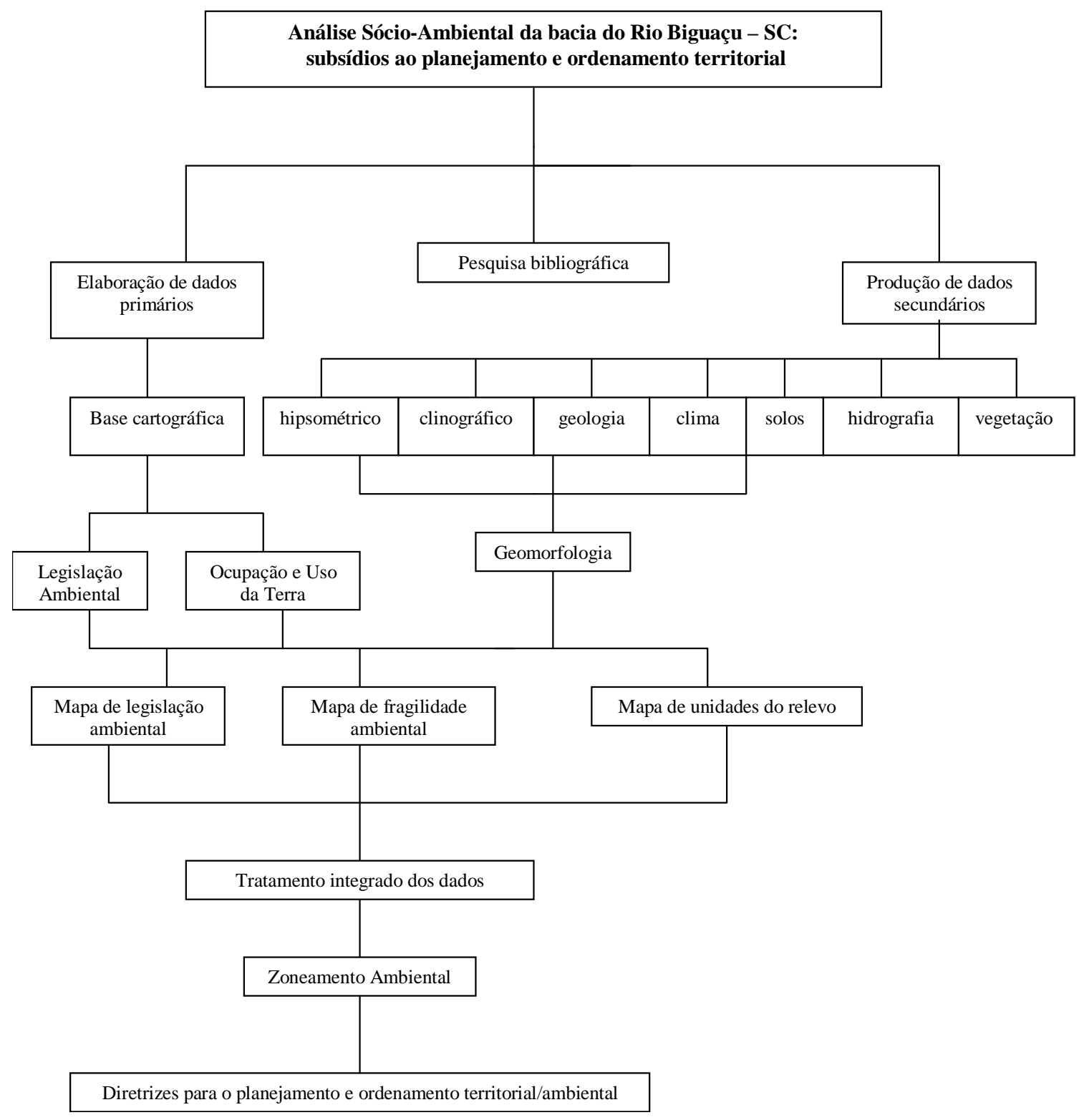

Elaboração: Vicente Rocha Silva.

Figura 2 - Fluxograma de atividades e produtos. 


\section{6-CARACTERIZAÇÃO GEOGRÁFICA: RESULTADOS DA PESQUISA}

\section{1 - O Ambiente Humanizado}

\subsection{1-Histórico da colonização de Biguaçu}

O processo de ocupação territorial de Biguaçu teve início com a fundação de São Miguel, no litoral, em 1747. Os primeiros povoadores do interior foram a partir de 1816, através de Manoel do Coito e Narciso Pereira D'Avilla, na localidade de Três Riachos (Soares, 1988, p.47). Visando garantir a posse das novas terras e consolidar a ocupação efetiva do território, o Governo Imperial decide fundar na região das nascentes do rio Biguaçu e Maruim, a Colônia de São Pedro de Alcântara. Essa colônia foi criada em 1829, formada por 112 alemães e 116 famílias teutas oriundas de Bremen na Alemanha. Alguns colonos alemães seguiram para outras localidades no Alto Biguaçu e Três Riachos (IBGE, 1959, p.26).

$\mathrm{Na}$ formação da população de Biguaçu, destacam-se três grupos étnicos: os portugueses imigrantes da Ilha de Açores; os negros vindos da África e utilizados como mãode-obra escrava, na exploração agrícola na região; e os alemães da cidade de Bremen. Os negros eram a principal mão-de-obra nos grandes latifúndios no vale do rio Biguaçu.

A freguesia de São Miguel, em 1816, abrangia o litoral catarinense desde a barra do rio Camboriú (ao norte), até o rio Serraria (ao sul), hoje divisa entre os municípios de Biguaçu e São José (Soares, 1988, p.23). A presença de imigrantes alemães se caracterizou pela exploração da terra no interior de Biguaçu e em novas áreas no vale do rio do Louro e rio Rachadel (Alto Biguaçu). Em 1833, São Miguel da Terra Firme é elevado à categoria de vila. O povoado tinha em 1810 cerca 3.564 habitantes (IBGE, 1959, p.26).

Em 1840, os açorianos iniciaram o desbravamento das planícies férteis do Alto Biguaçu, utilizando no trabalho agrícola, o escravo negro. A população negra consolidou a ocupação das planícies. As áreas montanhosas foram ocupadas por imigrantes alemães no período de 1840 a 1880 (Kremer, 1993, p.23).

De acordo com o IBGE (1959, p.27), foram dois núcleos de povoamento na formação do município de Biguaçu. O primeiro e maior núcleo foi de origem açoriana, localizado em São Miguel.Os colonos portugueses também ocuparam ao sul de São Miguel, na barra do rio 
Biguaçu, Três Riachos e Amâncios. O segundo núcleo formado por alemães instalados inicialmente na Colônia São Pedro de Alcântara que posteriormente, assentaram em vales de rios de outros tributários do rio Biguaçu.

A sede do município de São Miguel continuou na respectiva vila até 1886, quando foi transferida a sede para o povoado de Biguaçu. Em 1888, volta a ser sede em São Miguel. A sede do município de Biguaçu foi instalada definitivamente no povoado de Biguaçu, em 22 de maio de 1894 (IBGE, 1959, p.27). Soares (1988) descreve que a economia de Biguaçu no século 19 era baseada na farinha de mandioca, no milho, no corte da madeira e na pesca.

No Alto Biguaçu, os alemães, alguns anos depois, começaram a produzir um excedente de produção agrícola e madeira, dando início ao comércio entre a colônia e a freguesia de São Miguel. O meio de transporte utilizado no escoamento da produção foi através da navegação fluvial do rio Biguaçu. Essa atividade permitiu a instalação de comerciantes junto à foz do rio, com estaleiro e serrarias, na vila de Biguaçu (Soares, 1988, p.33).

\subsection{2-Histórico da colonização de Antônio Carlos}

A criação do distrito na localidade do Louro ocorreu pela lei municipal $\mathrm{n}^{\circ} 121$ de Biguaçu, em 15/07/1919. A sede do distrito do Louro foi transferida para a localidade conhecida por "Encruzilhada" ou Coração de Jesus. Anos mais tarde, o distrito passou a ser denominado de Antônio Carlos, através do decreto nº24 de 09/12/1930 (Kramer, 1993; Hoffmann, 1993, p.2).

De acordo com Raulino Reitz (1988), o atual município de Antônio Carlos era conhecido oficialmente por "Rio Biguassú", em meados do século 19. Para o autor (op. cit.) "o nome mais em uso, desde o início do século 20, que ainda persiste hoje é Alto Biguaçu” (Reitz, 1988, p.192). No entanto, a origem do nome atual do município se deve à homenagem ao político mineiro, Antônio Carlos Ribeiro de Andrada, nascido em 1870 e falecido em 1946. Em 1938, o distrito de Antônio Carlos é elevado à categoria de vila, com a delimitação do perímetro urbano e suburbano, a partir de 1\%/01/1939 (Hoffmann, 1993, p.2).

A criação do município de Antônio Carlos foi através da Lei Estadual nº928 de 6 de novembro de 1963, com uma área de 205 km², desmembrado do município de Biguaçu. 
O antigo distrito de Biguaçu começou a ser colonizado em 1830, onde João Henrique Schoeting liderou um grupo de dez famílias e instalaram-se às margens do rio do Louro em 6 de maio de 1830. Tratava-se da extensão física da Colônia de São Pedro de Alcântara (primeira Colônia Alemã em Santa Catarina, fundada em 1829). Os primeiros colonos de Antônio Carlos são originários do estado da Renânia-Palatinado, especialmente do altiplano Hunsruck. Atualmente cerca de $80 \%$ da população de Antônio Carlos são descendentes de alemães (PMAC, 2001).

A exploração econômica das terras do vale do rio Biguaçu, deve-se às imigrantes açorianos, instalados em São Miguel e que iniciaram o cultivo em terras devolutas, com mãode-obra escrava. Em 1847, o presidente da província determinou a criação da Colônia Leopoldina, visando a colonização do Alto Biguaçu, em terras devolutas remanescentes, nos vales dos rios Biguaçu, Rachadel e Farias. Porém, essa colônia não prosperou tendo em vista as dificuldades de comunicação e receio crescente do contato com povos nativos (bugres) pelos colonos alemães. A colônia foi desativada em 1857 (Soares, 1988, p.44). A área ocupada pela antiga Colônia Leopoldina é hoje denominada de Faxinal (alto vale do rio Rachadel) no município de Antônio Carlos.

A ocupação das terras em áreas localizadas na planície só ocorreu a partir de 1867, próxima a Vila 12 de Outubro. Essas terras pertenceram aos descendentes dos primeiros açorianos que se instalaram na região (Elicher, 2002, 88).

A vocação dos colonos alemães recém assentados nessa região tinha como base a subsistência. Assim, eram praticadas pequenas hortas, o cultivo de grãos, a criação de animais de pequeno porte, com o fornecimento de carne, leite e derivados (Elicher, 2002, p.88).

A importância do Alto Biguaçu era cada vez maior na economia do município de Biguaçu, onde o rio Biguaçu exerceu papel vital no escoamento da produção da colônia. Essa via de transporte teve o seu apogeu entre 1895 a 1916, quando ocorreu uma enchente catastrófica, interrompendo a navegação. Raulino Reitz descreve que a grande enchente “assoreou o leito do rio Biguaçu com barro, areia, tocos de pau, galhadas de árvores"(Reitz, 1988, p.405). O autor acrescenta que o entulhamento do rio Biguaçu foi completo, inclusive na foz. A eleição do comerciante João Nicolau Born, em 1873, representante do Alto 
Biguaçu, "região que já fornecia o suporte econômico para a sobrevivência do município" (Soares, 1988, p.52).

\subsection{3-Aspectos humanos de Biguaçu}

Segundo dados do Censo do IBGE (2000), a população total de Biguaçu é de 48.077 habitantes. A população urbana é dominante com 42.907 habitantes $(89,25 \%)$ e a população rural é de apenas 5.170 habitantes (10,5\%). A superfície do município é de $302 \mathrm{~km}^{2}$. A densidade demográfica é de 159,19 hab. $/ \mathrm{km}^{2}$. A cidade de Biguaçu possui localização privilegiada às margens da BR-101 e distante apenas $17 \mathrm{~km}$ da capital, tornando-se pólo alternativo de expansão de ocupação urbana (Monteiro, 2003, p.31). A área de influência da capital (área conurbada) é formada pelos municípios: Biguaçu, Florianópolis, Palhoça e São José. Da superfície total do município de Biguaçu $\left(302,9 \mathrm{~km}^{2}\right)$, cerca de 19,2 km² são de área urbana e 283,3 km² de área rural (Santa Catarina, 2005c, p.3).

Com base nos censos do IBGE realizados nos anos de 1950, 1960, 1970, 1980, 1991 e 2000, verifica-se que em Biguaçu o contingente de pessoas que vivem no meio rural vem decrescendo a partir de 1980. Em 1950, o percentual de população urbana era de 17,89\% e em 2000, chega a 89,25\%. Atualmente, predomina o crescimento espontâneo e sem qualquer critério de ordenamento territorial.

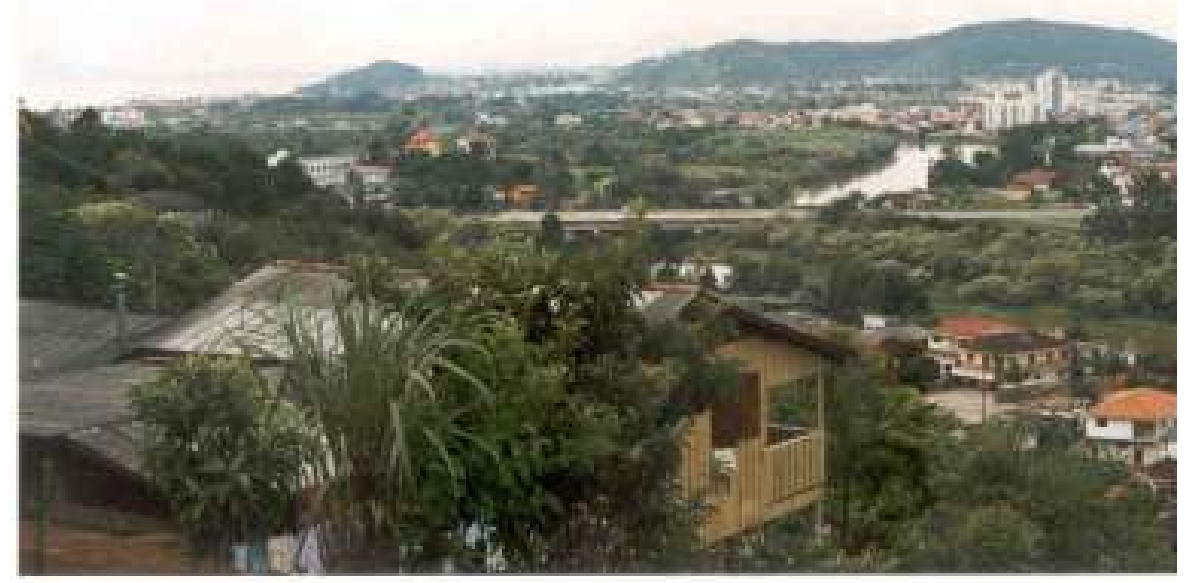

Figura 3 - Baixo vale do rio Biguaçu, vista do bairro Jardim Tibúrcio (Serra de São Miguel) na cidade de Biguaçu - SC. (Foto Edison Fortes, fevereiro/2005). 
As novas moradias, em geral, são construídas em locais inadequados, como na planície de inundação dos rios Caveiras e Biguaçu, em áreas do manguezal e em locais de riscos a deslizamento de encostas nos morros da cidade. $\mathrm{O}$ crescimento rápido e desordenado da população em Biguaçu permitiu o surgimento de uma favela no bairro Saveiros, na planície marinha, onde pessoas de baixa renda instalaram moradias em locais insalubres e sem infra-estrutura (Monteiro, 2003, p.34).

No levantamento de informações realizado em Biguaçu sobre as principais atividades econômicas, foram citadas: a indústria, o plantio de grama, a horticultura e a pecuária bovina de corte semi-extensiva, cultivos e plantas ornamentais, segundo o Eng. Agrônomo Waldemiro Sudoski (inf. verbal, 2005). A indústria de transformação se mantém como o setor que mais emprega. Oferece cerca de 1.500 vagas, de acordo com o relatório de 2001 do Ministério do Trabalho. Na indústria, a pioneira do segmento de plásticos é a Inplac, inaugurada em 1974, às margens da BR-101. Os dados do Ministério do Trabalho destacam o número de empregos em 2001 em Biguaçu, assim distribuídos: indústria (1.528), construção civil (717), comércio (865) e serviços (960) (Monteiro, 2003, p.33). 
Tabela 2 - População urbana e rural dos municípios de Biguaçu e Antônio Carlos-SC.

\begin{tabular}{|c|c|c|c|c|c|c|c|c|}
\hline Anos & Biguaçu & Urbana & Rural & Total & A.Carlos & Urbana & Rural & Total \\
\hline 1900 & & & & 9.548 & & & & \\
\hline 1920 & & & & 8.184 & & & & 3.490 \\
\hline 1940 & & 2.478 & 7.773 & 10.251 & & 183 & 3.772 & 3.955 \\
\hline 1950 & & 1.756 & 8.064 & 9.820 & & 269 & 4.078 & 4.347 \\
\hline 1960 & & 2.172 & 8.145 & 10.317 & & 799 & 3.723 & 4.522 \\
\hline 1970 & & 9.097 & 6.240 & 15.337 & & 502 & 5.122 & 5.624 \\
\hline 1980 & & 16.101 & 5.333 & 21.434 & & 718 & 4.699 & 5.417 \\
\hline 1991 & & 28.207 & 5.826 & 34.063 & & 977 & 4.636 & 5.613 \\
\hline $1996(*)$ & & 35.110 & 4.937 & 40.047 & & 1.210 & 4.797 & 6.007 \\
\hline 2000 & & 42.907 & 5.170 & 48.077 & & 1.760 & 4.674 & 6.434 \\
\hline $2001(* *)$ & & & & 49.722 & & & & 6.518 \\
\hline $2002(* *)$ & & & & 51.026 & & & & 6.607 \\
\hline $2003(* *)$ & & & & 52.394 & & & & 6.687 \\
\hline $2004(* *)$ & & & & 55.267 & & & & 6.855 \\
\hline $2004(* * *)$ & & & & & & 3.068 & 4.021 & 7.089 \\
\hline $2005(* *)$ & & & & 56.857 & & & & 6.948 \\
\hline $2006(* *)$ & & & & 58.435 & & & & 7.041 \\
\hline
\end{tabular}

Fontes: Censo do IBGE, (*) IBGE - Contagem da população (1996), (**) IBGE -Estimativa da população residente (2001 a 2006), (***) Programa de Saúde da Família (PSF) da Prefeitura Municipal de Antônio CarlosSC. 


\subsection{4-Aspectos humanos de Antônio Carlos}

De acordo com o Censo do IBGE (2000), a população do município de Antônio Carlos era de 6.434 habitantes. Deste total, cerca de 1.760 habitantes $(27,35 \%)$ é urbana e 4.674 habitantes $(72,65 \%)$ de população rural. O município possui área territorial de $205 \mathrm{~km}^{2}$. A densidade demográfica é de 31,38 hab. $/ \mathrm{km}^{2}$. A cidade situa-se a $14 \mathrm{~km}$ de Biguaçu e a $33 \mathrm{~km}$ de Florianópolis. É um dos municípios de Santa Catarina com os maiores percentuais de população que vive no meio rural (IBGE, 2000). O perímetro urbano tem 79,9km $(38,98 \%$ ) e a área rural com 125,1km (61,02\%) (Hoffmann, 1993, p.5). O núcleo urbano de Antônio Carlos sempre teve a função principal de servir e dar suporte para as propriedades na área rural e produção agrícola (Elicher, 2002, p.94).

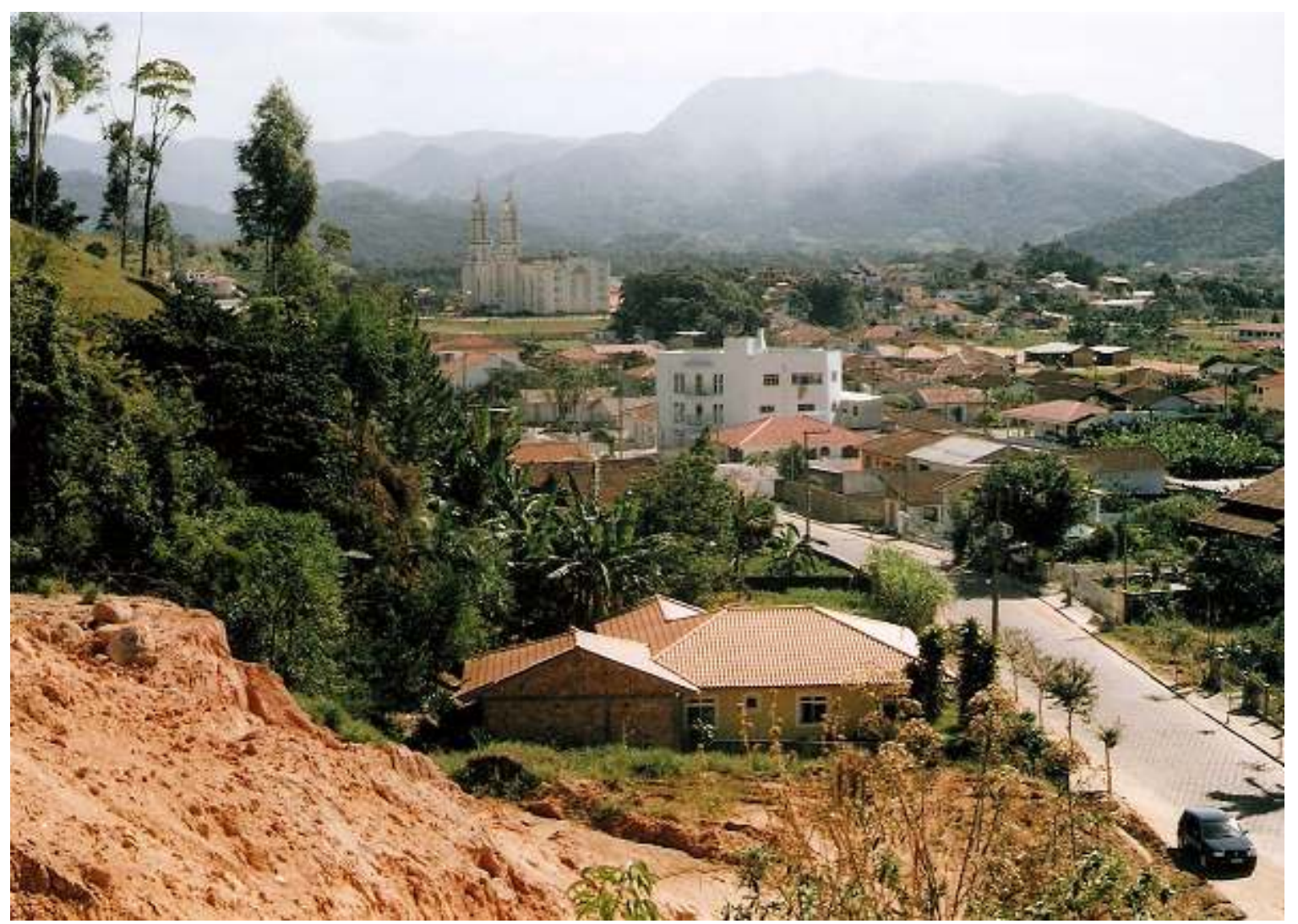

Figura 4 -Vista parcial da cidade de Antônio Carlos - SC, em destaque a Igreja Matriz. (Foto: Vicente R. Silva, abril/2006).

Segundo dados do Ministério do Trabalho, o número de empregos em 2001 aponta na indústria (415), construção civil (6), comércio (89) e serviços (443) (Monteiro, 2003, p.33). Antônio Carlos possui uma única empresa de grande porte, que é a fábrica de refrigerantes e cerveja (Refrescos Vonpar) (Pauli, 2001, p.16). Esta indústria está localizada às margens da 
SC-408, próximo da divisa com Biguaçu. Outros setores da economia de menor porte são representados por cinco fábricas de móveis, cinco madeireiras, três confecções, dez alambiques de cachaça e quatro engenhos de farinha (Elicher, 2002, p.96).

No turismo podemos destacar no interior do município a presença de seis parques aquáticos. Na localidade do Louro, foi instalado o primeiro parque aquático, em 1995, a cerca de $10 \mathrm{~km}$ da cidade. Antônio Carlos é tido como "um bom exemplo de município rural que, inserido numa região dinâmica, possui várias oportunidades de luta contra a exclusão social e pela geração de emprego" (Seben, 2001, p.61).

Segundo estudo realizado por Pauli (2001, p.64), o município possui natureza exuberante, com vasta extensão e propício para o desenvolvimento de atividades relacionadas ao turismo ecológico. A municipalidade apresenta alto índice de qualidade de vida a nível estadual, sendo o primeiro na microrregião de Florianópolis.

\section{2-Aspectos Sócio-econômicos}

\subsection{1-A estrutura agrária dos municípios de Biguaçu e Antônio Carlos}

A estrutura agrária dos dois municípios estudados é semelhante, pois Antônio Carlos teve sua origem ligada à fundação de São Miguel (atual município de Biguaçu). No entanto, como o antigo distrito de Alto Biguaçu, recebeu imigrantes de origem européia, através da colônia de São Pedro de Alcântara. Esta colônia rural foi estruturada no trabalho livre, dividida em parcelas de terras bem menores, com o objetivo de tirar o sustento através da exploração dos recursos naturais e o cultivo da terra.

Desde a formação do núcleo de povoamento de São Miguel (1747), a estrutura fundiária era baseada em grandes propriedades. Porém, esse quadro começou a mudar após 1830, com a diminuição gradativa do número de escravos que trabalhavam na agricultura. Essa mudança tornou-se mais intensa, com o advento da abolição da escravatura. A sucessão por herança e o processo de compra implantado posteriormente levam o município a um padrão de medias e pequenas propriedades (Prates; Corrêa, 1989, p.33). 
Tabela 3 - Estrutura fundiária do município de Biguaçu - SC.

\begin{tabular}{|l|c|c|c|c|c|c|c|c|c|}
\hline \multirow{2}{*}{$\begin{array}{l}\text { Grupo área } \\
\text { (ha) }\end{array}$} & \multicolumn{3}{|c|}{$\mathbf{N}^{\mathbf{0}}$ Estabelecimentos } & \multicolumn{7}{c|}{ Área Total (ha) } \\
\cline { 2 - 10 } & 1970 & 1980 & 1985 & 1970 & $\%$ & 1980 & $\%$ & 1985 & $\%$ \\
\hline$<20$ & 832 & 765 & 749 & 5.931 & 28,49 & 4.826 & 23,72 & 4.971 & 22,30 \\
\hline $20-50$ & 161 & 148 & 172 & 4.550 & 21,86 & 4.371 & 21,49 & 4.964 & 22,27 \\
\hline $50-100$ & 40 & 34 & 32 & 2.772 & 13,32 & 2.169 & 10,66 & 2.157 & 9,68 \\
\hline $100-500$ & 20 & 23 & 22 & 3.957 & 19,02 & 4,627 & 22,74 & 3.945 & 17,70 \\
\hline$>500$ & 3 & 5 & 8 & 3.602 & 17,31 & 4.346 & 21,36 & 6.245 & 28,02 \\
\hline Total & 1.056 & 975 & 983 & 20.812 & 100 & 20.339 & 100 & 22.282 & 100 \\
\hline
\end{tabular}

Fonte: IBGE. Censo Agropecuário de Santa Catarina (1970, 1980)

Sinopse Preliminar do Censo Agropecuário de Santa Catarina (1985)

Verifica-se em Biguaçu o predomínio de pequenas propriedades (749), com áreas de até 20 ha em 1985. Dos 983 estabelecimentos rurais do município em 1985, que tinham até 50 há, $94 \%$ são caracterizados como minifúndios e médios. Essas propriedades ocupam aproximadamente 45\% do total de terras do município (Santa Catarina, 1990, p.13), conforme a tabela 3. É oportuno esclarecer que uma parte menor da área do município de Biguaçu pertence a bacia do rio Inferninho, estando portanto, fora da área de estudo.

Tabela 4 - Estrutura fundiária do município de Antônio Carlos - SC.

\begin{tabular}{|l|c|c|c|c|c|c|c|c|c|}
\hline \multirow{2}{*}{$\begin{array}{l}\text { Grupo área } \\
\text { (há) }\end{array}$} & \multicolumn{3}{|c|}{$\mathbf{N}^{\mathbf{0}}$ Estabelecimentos } & \multicolumn{7}{c|}{ Área Total (ha) } \\
\cline { 2 - 10 } & 1970 & 1980 & 1985 & 1970 & $\%$ & 1980 & $\%$ & 1985 & $\%$ \\
\hline$<20$ & 307 & 523 & 527 & 2742 & 20,31 & 3888 & 23,40 & 4038 & 20,27 \\
\hline $20-50$ & 232 & 250 & 263 & 7004 & 51,90 & 7870 & 47,37 & 8195 & 41,15 \\
\hline $50-100$ & 40 & 42 & 42 & 2410 & 17,85 & 2590 & 15,59 & 2605 & 13,08 \\
\hline $100-500$ & 10 & 4 & 12 & 1339 & 9,92 & 465 & 2,79 & 2074 & 10,41 \\
\hline$>500$ & - & 1 & 3 & - & 0,0 & 1800 & 10,83 & 3000 & 15,06 \\
\hline Total & 589 & 820 & 847 & 13495 & 100 & 16,613 & 100 & 19912 & 100 \\
\hline
\end{tabular}

Fonte: IBGE. Censo Agropecuário de Santa Catarina $(1970,1980)$

Sinopse Preliminar do Censo Agropecuário de Santa Catarina (1985)

Quanto a estrutura fundiária no município de Antônio Carlos, verifica-se o predomínio de propriedades com áreas de até 50 hectares. Em 1985, 93,27\% dos 847 estabelecimentos rurais são caracterizados por médio ou minifúndios. A área ocupada por pequenas propriedades representa $61,43 \%$ do total de terras destinadas à agricultura do município (Santa Catarina, 1990a, p.13), conforme os dados da tabela 4.

\subsection{2-O Uso da Terra}

A tipologia de cobertura e uso da terra reflete a intensidade de ação humana sobre os diferentes ambientes, substituindo a cobertura vegetal expontânea por padrões estruturais de produção agrária e de urbanização. O estado de Santa Catarina apresenta em sua divisão fundiária, o predomínio dos pequenos estabelecimentos rurais, geralmente, submetidos à 
exploração intensiva de variada gama de produtos, fundamentada no trabalho familiar (Leite, 2003, p.7).

Nos dois municípios estudados, a cobertura natural possui maior expressão na área de vegetação secundária da Floresta Ombrófila Densa com seus diferentes estágios de sucessão ecológica (Leite, 2003, p.8).

A vegetação secundária em estágio avançado de desenvolvimento (capoeirões), ocorre em áreas de relevo ondulado e forte-ondulado ou em terras baixas brejosas. É freqüente estar associado a outros tipos de cobertura e uso da terra, como o reflorestamento, pastagens e bananal (Leite, 2003, p.14).

Na bacia do rio Rachadel, no município de Antônio Carlos, Neis (1997, p.26) realizou mapeamento de cobertura e uso da terra, nos anos 1957, 1978 e 1995, e concluiu que em 1995 a cobertura vegetal aumentou devido ao processo de regeneração, representando $61 \%$ do total da bacia.

Tabela 5 - Estabelecimentos por grupo de atividade econômica, segundo municípios de Antônio Carlos e Biguaçu-SC.

\begin{tabular}{|l|c|c|c|c|c|c|c|c|}
\hline \multirow{2}{*}{ Municípios } & \multicolumn{9}{|c|}{\begin{tabular}{c} 
Grupo de Atividades Econômicas \\
\cline { 2 - 9 }
\end{tabular}} & $\begin{array}{c}\text { Lavoura } \\
\text { temp }\end{array}$ & horti & $\begin{array}{c}\text { lavoura } \\
\text { perm }\end{array}$ & $\begin{array}{c}\text { Pecuári } \\
\text { a }\end{array}$ & $\begin{array}{c}\text { produção } \\
\text { mista }\end{array}$ & $\begin{array}{c}\text { silvicultura e exp. } \\
\text { Florestal }\end{array}$ & $\begin{array}{c}\text { pesca e } \\
\text { agricultura }\end{array}$ & $\begin{array}{c}\text { produção de carvão } \\
\text { vegetal }\end{array}$ \\
\hline A. Carlos & 173 & 345 & 39 & 45 & 108 & 4 & - & 1 \\
\hline Biguaçu & 184 & 93 & 47 & 180 & 96 & 4 & 1 & - \\
\hline
\end{tabular}

Fonte: Censo Agropecuário 1995-1996 - Santa Catarina - IBGE n. ${ }^{2} 1$ - Rio de Janeiro - 1997

A tabela 5 (acima) mostra que em Antônio Carlos a horticultura é uma atividade destacada, com 345 estabelecimentos especializados na produção de verduras e legumes. Em Biguaçu a atividade pecuária representa cerca de 180 propriedades ligadas a essa atividade econômica. A pastagem plantada ocupa lugar de destaque na bacia do rio Biguaçu, pois apresenta ampla distribuição e expressão espacial. Ocorre em diversos tipos de ambientes. As áreas mais representativas localizam-se na planície fluvial do rio Biguaçu e Três Riachos.

No município de Antônio Carlos, houve muita evolução e crescimento da agricultura. $\mathrm{Na}$ década de 1970, ocorreu a substituição do plantio de cana-de-açúcar e mandioca que alimentava os engenhos, para uma exploração mais intensiva de olericultura. Em Antônio 
Carlos não há famílias com restrições ao acesso à terra e não ocorre problemas fundiários graves (Plano Municipal de Desenvolvimento Rural Sustentável -2005/2008, (2005, p.9).

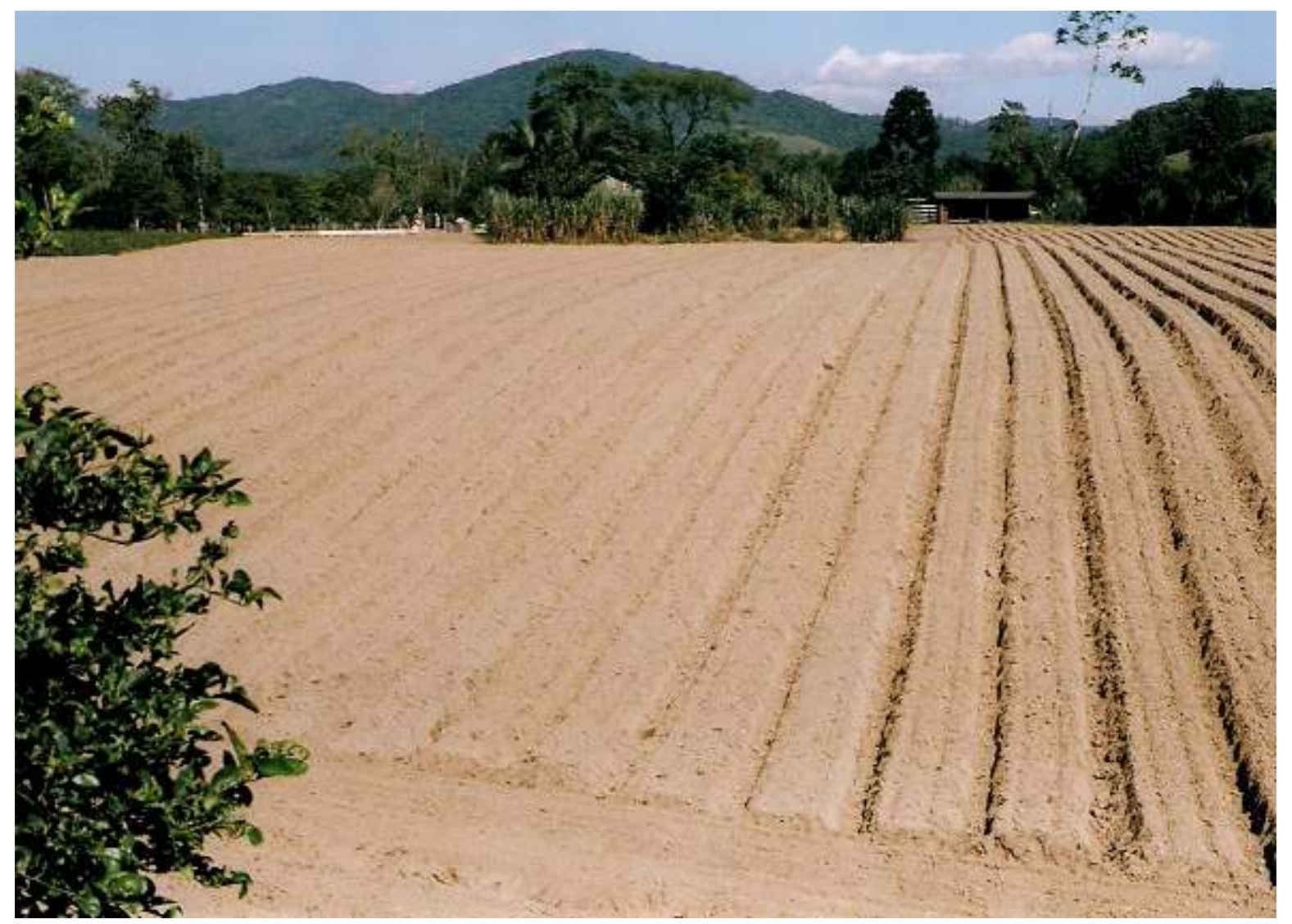

Figura 5 - Solo preparado para o cultivo de hortaliça as margens do Rio Biguaçu, na localidade Beira Rio, no município de Antônio Carlos - SC. (Foto: Vicente R. Silva, abril/2006)

Tabela 6 - Distribuição de numero de proprietários em relação à posse da terra, no município de Antônio Carlos-2002.

\begin{tabular}{|c|c|c|}
\hline Estrato de área (ha) & n. $^{\text {o de proprietários }}$ & $\mathbf{\%}$ \\
\hline Até 2 & 39 & 4,4622 \\
\hline 2 a 5 & 214 & 24,4851 \\
\hline 6 a 10 & 198 & 22,6544 \\
\hline 11 a 20 & 198 & 22,6544 \\
\hline 20 a 50 & 199 & 22,7688 \\
\hline$>50$ & 26 & 2,9748 \\
\hline Total & $\mathbf{8 7 4}$ & $\mathbf{1 0 0 \%}$ \\
\hline
\end{tabular}

Fonte: INCRA-2002 (apud) Plano Municipal de Desenvolvimento Rural Sustentável (2005/2008), município de Antônio Carlos. 
$\mathrm{Na}$ tabela 6 acima, percebe-se o predomínio dos minifúndios no meio rural do município de Antônio Carlos, pois as áreas de até 10 hectares correspondem a 51,60\% do total da área destinado ao setor agropecuário do município.

Tabela 7 - Utilização das terras no município de Biguaçu-SC (1970/1980/1985).

\begin{tabular}{|l|c|c|c|c|c|c|}
\hline \multirow{2}{*}{$\begin{array}{l}\text { Utilização } \\
\text { Das Terras }\end{array}$} & \multicolumn{2}{|c|}{$\mathbf{1 9 7 0}$} & \multicolumn{2}{c|}{$\mathbf{1 9 8 0}$} & \multicolumn{2}{c|}{$\mathbf{1 9 8 5}$} \\
\cline { 2 - 7 } & Área (há) & $\%$ & Área (há) & $\%$ & Área (há) & $\%$ \\
\hline Lav.Temp. & 4048 & 15,38 & 3897 & 19,16 & 2965 & 13,31 \\
\hline Lav. Perm. & 1477 & 5,61 & 1187 & 5,83 & 1027 & 4,61 \\
\hline Past. Naturais & 2191 & 8,32 & 4629 & 22,75 & $X$ & $X$ \\
\hline Past. Plantadas & 1522 & 5,78 & 1493 & 7,34 & $X$ & $X$ \\
\hline Fl. Naturais & 5512 & 20,94 & 5122 & 25,18 & $X$ & $X$ \\
\hline Fl. Plantadas & 24 & 0,09 & 57 & 0,28 & $X$ & $X$ \\
\hline $\begin{array}{l}\text { Produtiva/não } \\
\text { útil./descanso }\end{array}$ & 5204 & 19,77 & 1979 & 9,73 & $\mathrm{X}$ & $\mathrm{X}$ \\
\hline Improdutivas & 833 & 24,11 & 1980 & 9,73 & $\mathrm{X}$ & $\mathrm{X}$ \\
\hline Total & 20811 & 100 & 20344 & 100 & 22282 & 100 \\
\hline
\end{tabular}

Fonte: Censo Agropecuário de Santa Catarina - IBGE 1970/1980

IBGE -Sinopse Preliminar do Censo Agropecuário de SC, $1985 \quad$ (X) Dado não disponível

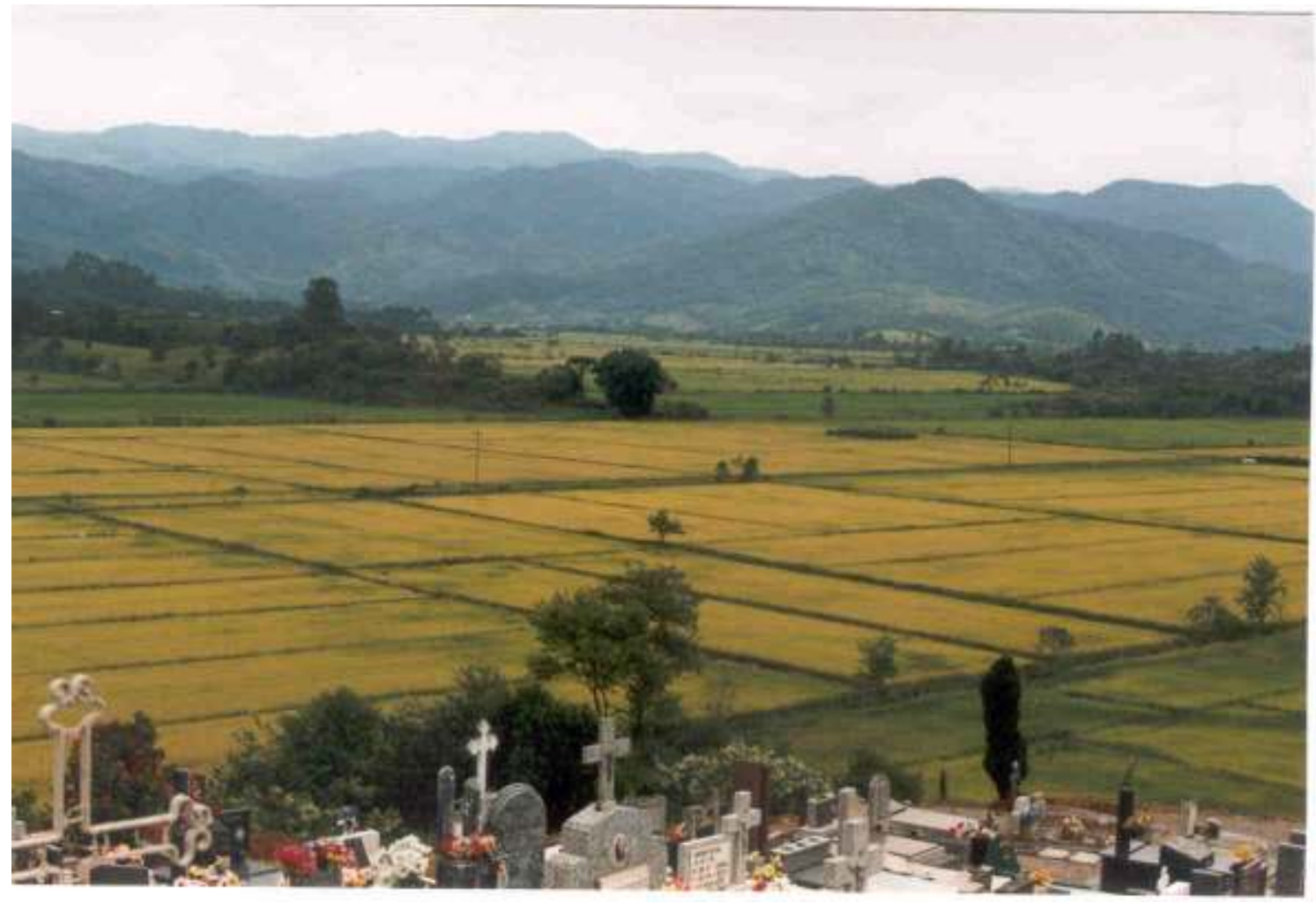

Figura 6 :Vista do vale do rio Três Riachos, com plantação de arroz e pastagens na planície e vegetação secundária nas encostas. Foto tirada do topo da colina (Igreja de São Sebastião de Limeira), na localidade de Limeira, em Biguaçu-SC. (Foto Edison Fortes, fevereiro/2005). 
No período de 1970/1985 ocorreu um decréscimo na utilização das terras, tanto para lavouras temporárias com perca de 1083 ha, como para lavouras permanentes com redução de 450 ha. Por outro lado no período 1970/1980 ocorreu um aumento expressivo de áreas destinadas às pastagens naturais e possivelmente uma melhor utilização de terras produtivas em descanso. Em 1980 essas terras representavam 5204 há, e destas 3225 ha passaram a ser exploradas economicamente (Santa Catarina, 1990b, p.14), conforme a tabela 7.

Tabela 8 - Utilização das terras no município de Antônio Carlos-SC (1970/1980/1985).

\begin{tabular}{|l|c|c|c|c|c|c|}
\hline \multirow{2}{*}{$\begin{array}{l}\text { Utilização } \\
\text { Das Terras }\end{array}$} & \multicolumn{2}{|c|}{$\mathbf{1 9 7 0}$} & \multicolumn{2}{c|}{$\mathbf{1 9 8 0}$} & \multicolumn{2}{c|}{$\mathbf{1 9 8 5}$} \\
\cline { 2 - 7 } & Área (ha) & $\%$ & Área (ha) & $\%$ & Área (ha) & $\%$ \\
\hline Lav. Temp. & 3074 & 22,78 & 2531 & 15,23 & 2758 & 13,85 \\
\hline Lav. Perm. & 681 & 5,05 & 994 & 5,98 & 1043 & 5,24 \\
\hline Past. Nat. & 1996 & 14,79 & 156 & 0,94 & $\mathrm{X}$ & $\mathrm{X}$ \\
\hline Past. Plant. & 36 & 0,27 & 3214 & 19,34 & $\mathrm{X}$ & $\mathrm{X}$ \\
\hline Fl. Natural & 2600 & 19,27 & 2781 & 16,74 & $\mathrm{X}$ & $\mathrm{X}$ \\
\hline Fl. Plant. & 64 & 0,47 & 290 & 1,75 & $\mathrm{X}$ & $\mathrm{X}$ \\
\hline $\begin{array}{l}\text { Produtiva/não } \\
\text { útil./descanso }\end{array}$ & 3534 & 26,19 & 3423 & 20,60 & $\mathrm{X}$ & $\mathrm{X}$ \\
\hline Improdutivas & 1509 & 11,18 & 3227 & 19,42 & $\mathrm{X}$ & $\mathrm{X}$ \\
\hline Total & 13494 & 100 & 16616 & 100 & 19912 & 100 \\
\hline
\end{tabular}

Fonte: Censo Agropecuário de Santa Catarina - IBGE 1970/1980

Sinopse Preliminar do Censo Agropecuário de SC, IBGE $1985 \quad$ (X) Dado não disponível

A área de lavouras temporárias teve um pequeno aumento no período 1980/1985. Antônio Carlos tem se transformado em pólo de produção de hortaliças na microrregião de Florianópolis. As áreas de pastagens plantadas tiveram um aumento considerável no período 1970/1980, passando de 36 há (0,27\%) em 1970 para 3214 há (19,34\%) em 1980. Também podemos destacar o aumento gradativo de áreas destinadas as lavouras permanentes de 681 ha (5,05\%) em 1970 passando para 1043 há (5,24\%) em 1985, conforme a tabela 8 .

Com relação a aptidão do solo, no setor produtivo em relação a declividade de 0 a $20 \%$, o cultivo de hortaliças (exclusivo), chega a 3075 hectares (15\%) do total. Também é expressivo a área destinada a olericultura e fruticultura, chegando a 9225 hectares, ou seja, 45 $\%$ do total da área, conforme dados da tabela 9. 
Tabela 9- Classe de aptidão de uso das terras do município de Antônio Carlos-SC.

\begin{tabular}{|c|c|c|c|}
\hline & & & \\
Classe de solo em relação à declividade & Aptidão de uso & Área em hectares & \% \\
\hline $1(0 \mathrm{a} 8 \%)$ & Olericultura & 2.050 & 10 \\
\hline $2(8 \mathrm{a} 20 \%)$ & Olericultura & 1.025 & 5 \\
\hline $3(20 \mathrm{a} 45 \%)$ & Olericultura e fruticultura & 6.150 & 30 \\
\hline $4(45 \mathrm{a} 75 \%)$ & Reflorestamento & 2.460 & 12 \\
\hline $5(>75 \%)$ & Mata (Floresta Ombrófila Densa) & 8.815 & 43 \\
\hline Total & & $\mathbf{2 0 . 5 0 0}$ & $\mathbf{1 0 0}$ \\
\hline
\end{tabular}

Fonte: Epagri - Antônio Carlos-SC (2004).

Tabela 10 - Ulização das terras no município de Antônio Carlos-SC

\begin{tabular}{|l|c|c|}
\hline \multicolumn{1}{|c|}{ Discriminação } & \multirow{2}{*}{ Área (ha) } & \% \\
\cline { 1 - 2 } Lavoũa e uso da terra & & 14,4 \\
\cline { 1 - 2 } Lavouras temporária (grãos e hortaliças) & 2.950 & 4,4 \\
\hline Capoeiras & 915 & 38,8 \\
\hline Campo nativo melhorado & 7.950 & 10,4 \\
\hline Matas naturais & 2.131 & 24,4 \\
\hline Reflorestamento & 5.000 & 0,9 \\
\hline Florestamento & 200 & 0,3 \\
\hline Terras inaproveitáveis & 50 & 6,4 \\
\hline Total & 1.310 & $\mathbf{1 0 0}$ \\
\hline
\end{tabular}

Fonte: Epagri - Antônio Carlos-SC (2004)

Na tabela 10 (acima), mostra o prodomínio de grande parte da bacia do rio Biguaçu, da mata atlântica, representada pela capoeiras que correspondem a 7950 hectares $(38,8 \%)$, que somados as áreas de matas naturais com 5.000 ha $(24,4 \%)$, representam no conjunto cerca de 12.950 ha ou seja, 63,2 \% do total de terras do município de Antônio Carlos. Na atividade produtiva os dados da Epagri de 2004, mostra a importância econômica da lavoura temporária (grãos e hortaliças), com 2.950 há (14,4\%) do total.

Na tabela 11 (abaixo), são do Censo Agropecuário de 1995-1996 do IBGE, onde podemos destacar o predomínio de áreas de pastagens naturais no município de Biguaçu em relação ao município de Antônio Carlos, comprovando a percepção impírica nos trabalhos de campo, que no meio rural de Biguaçu, os pastos possuem expressão espacial na bacia do rio Biguaçu. 
Tabela 11 - Utilização das terras, segundo os municípios de Antônio Carlos e Biguaçu-SC.

\begin{tabular}{|c|c|c|c|c|c|c|c|c|c|c|}
\hline \multirow{4}{*}{$\begin{array}{l}\text { Municíp } \\
\text { ios }\end{array}$} & \multirow{3}{*}{\multicolumn{2}{|c|}{ Total }} & \multicolumn{8}{|c|}{ Utilização das terras } \\
\hline & & & \multicolumn{3}{|c|}{ Lavoura } & \multicolumn{2}{|c|}{ Pastagens } & \multicolumn{2}{|c|}{$\begin{array}{c}\text { Matas e } \\
\text { florestas }\end{array}$} & \multirow[b]{2}{*}{$\begin{array}{c}\text { Produt. Não } \\
\text { utlizados }\end{array}$} \\
\hline & & & $\begin{array}{l}\text { Permane } \\
\text { ntes }\end{array}$ & $\begin{array}{l}\text { Temporá } \\
\text { rias }\end{array}$ & $\begin{array}{c}\text { Temp. em } \\
\text { descanso }\end{array}$ & $\begin{array}{c}\text { Natur } \\
\text { ais }\end{array}$ & $\begin{array}{c}\text { Planta } \\
\text { das }\end{array}$ & $\begin{array}{c}\text { Natur } \\
\text { ais }\end{array}$ & $\begin{array}{c}\text { Planta } \\
\text { das }\end{array}$ & \\
\hline & $\begin{array}{c}\text { Informa } \\
\text { nte }\end{array}$ & $\begin{array}{l}\text { área } \\
\text { (ha) }\end{array}$ & área (ha) & Área (ha) & área (ha) & $\begin{array}{l}\text { área } \\
\text { (ha) }\end{array}$ & $\begin{array}{l}\text { área } \\
\text { (ha) }\end{array}$ & $\begin{array}{l}\text { área } \\
\text { (ha) }\end{array}$ & $\begin{array}{c}\text { Área } \\
\text { (ha) }\end{array}$ & área (ha) \\
\hline $\begin{array}{l}\text { A. } \\
\text { Carlos }\end{array}$ & 715 & 10841 & 613 & 1743 & 434 & 723 & 1468 & 3217 & 273 & 651 \\
\hline Biguaçu & 605 & 14070 & 427 & 1899 & 80 & 3725 & 1654 & 4441 & 743 & 398 \\
\hline
\end{tabular}

Fonte: IBGE - Censo Agropecuário de Santa Catarina 1995-1996.

A produção agrícola do município de Biguaçu possui destaque na produção de arroz irrigado, aproveitando áreas de solos gleissolos na planície fluvial dos rios Saudade e Três Riachos. 
Tabela 12 - Produção agrícola do município de Biguaçu-SC

\begin{tabular}{|c|c|c|c|c|c|}
\hline $\begin{array}{l}\text { Produtos / } \\
\text { Ano } \\
\end{array}$ & 2001 & 2002 & 2003 & 2004 & 2005 \\
\hline $\begin{array}{l}\text { Abacaxi } \\
\text { (mil frutas) }\end{array}$ & 24 & 24 & 24 & 24 & 24 \\
\hline $\begin{array}{l}\text { Arroz em } \\
\text { casca } \\
\text { (ton.) }\end{array}$ & 3.000 & 3.000 & 5.250 & 5.600 & 5.600 \\
\hline $\begin{array}{l}\text { Batata- } \\
\text { doce (ton.) }\end{array}$ & 3.000 & 3.000 & 3.000 & 3.000 & 3.000 \\
\hline $\begin{array}{l}\text { Batata- } \\
\text { inglesa } \\
\text { (ton.) } \\
\end{array}$ & 150 & & & & \\
\hline $\begin{array}{l}\text { Cana-de- } \\
\text { açúcar } \\
\text { (ton.) }\end{array}$ & 13.500 & 13.500 & 13.500 & 13.500 & 13.500 \\
\hline $\begin{array}{l}\text { Cebola } \\
\text { (ton.) }\end{array}$ & 80 & & & & \\
\hline $\begin{array}{l}\text { Feijão em } \\
\text { grão (ton.) }\end{array}$ & 105 & 11 & 11 & 11 & 11 \\
\hline $\begin{array}{l}\text { Mandioca } \\
\text { (ton.) }\end{array}$ & 10.620 & 7.200 & 7.200 & 7.200 & 7.200 \\
\hline $\begin{array}{l}\text { Milho em } \\
\text { grãos } \\
\text { (ton.) }\end{array}$ & 660 & 660 & 660 & 720 & 720 \\
\hline $\begin{array}{l}\text { Tomate } \\
\text { (ton.) }\end{array}$ & 675 & 675 & 225 & 225 & 225 \\
\hline $\begin{array}{l}\text { Banana } \\
\text { (ton.) }\end{array}$ & 1.800 & 1.800 & 1.800 & 1.800 & 1.800 \\
\hline $\begin{array}{l}\text { Laranja } \\
\text { (ton.) }\end{array}$ & 280 & 280 & 280 & 280 & 280 \\
\hline $\begin{array}{l}\text { Maracujá } \\
\text { (ton.) }\end{array}$ & 225 & 225 & 225 & 225 & 225 \\
\hline $\begin{array}{l}\text { Tangerina } \\
\text { (ton.) }\end{array}$ & 30 & & 55 & 55 & 50 \\
\hline
\end{tabular}

Fonte: IBGE - Produção Agrícola Municipal de Biguaçu-SC. 
Também é expressivo o cultivo de banana, junto com as lavouras tradicionais da região como a cana-de-acúçar, mandioca e milho, conforme os dados da tabela 12 (acima).

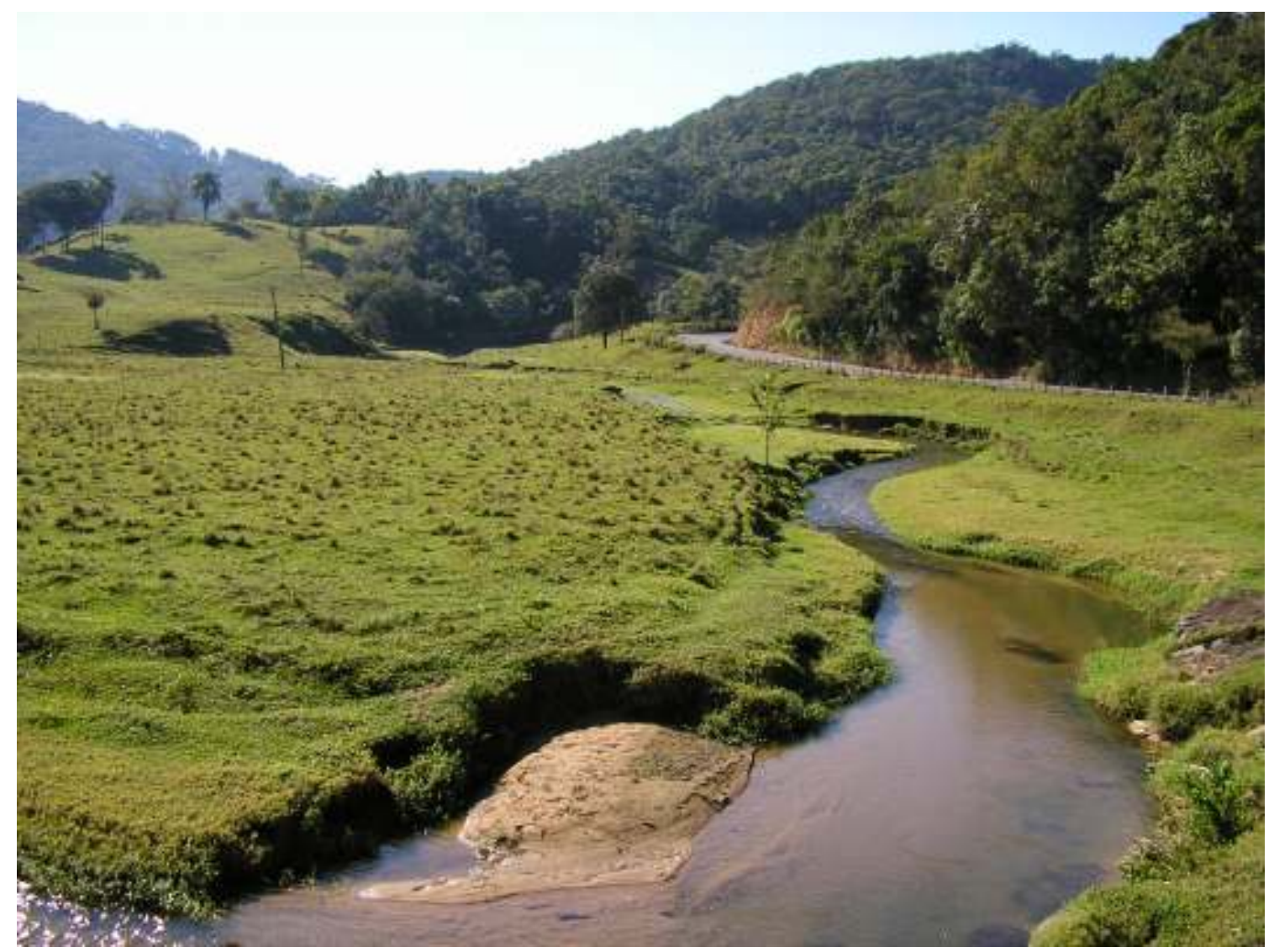

Figura 7 - Detalhe do vale do rio Rachadel, em $1^{\circ}$ plano, depósito de barra em pontal, em zona de pastagens, na localidade Rachadel, em Antônio Carlos-SC. (Foto Edison Fortes, julho/2005). 


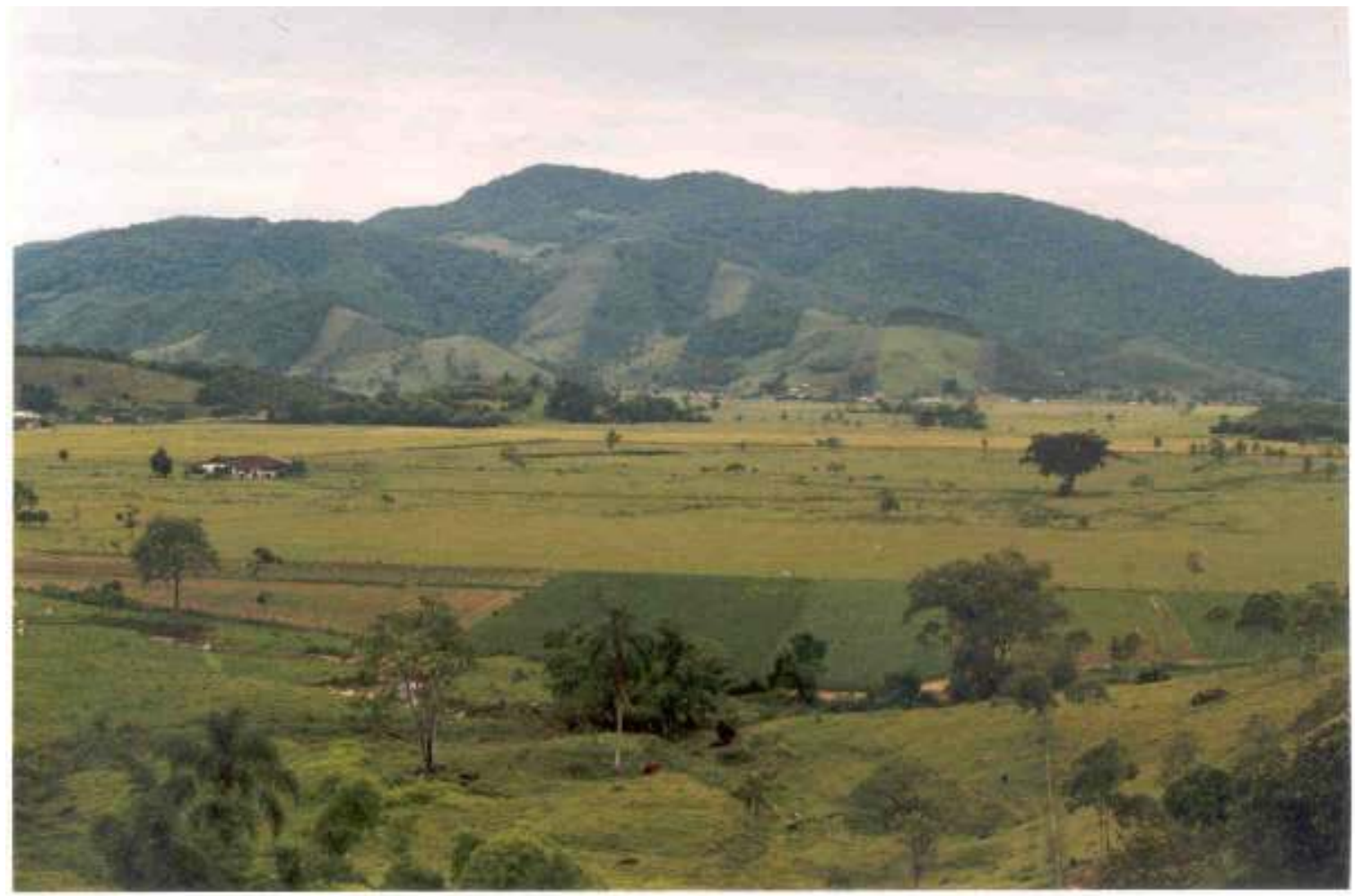

Figura 8 - Vale do rio Três Riachos. Ao fundo Serra de Guiomar (morro da Oratória). Uso da terra, pastagens e hortaliças, no município de Biguaçu -SC. (Fotos Edison Fortes, fevereiro/2005).

Tabela 13- Efetivos dos rebanhos do município de Biguaçu-SC (unidades)

\begin{tabular}{|l|c|c|c|c|c|}
\hline Efetivos & $\mathbf{2 0 0 1}$ & $\mathbf{2 0 0 2}$ & $\mathbf{2 0 0 3}$ & $\mathbf{2 0 0 4}$ & $\mathbf{2 0 0 5}$ \\
\hline Bovinos & 10.700 & 11.082 & 11.044 & 11.597 & 11.550 \\
\hline Suínos & 825 & 1.245 & 1.263 & 1.490 & 1.520 \\
\hline Eqüinos & 310 & 407 & 414 & 420 & 420 \\
\hline Bubalinos & 70 & 300 & 250 & 240 & 240 \\
\hline Coelhos & 220 & 150 & 125 & 100 & 100 \\
\hline Ovinos & 198 & 369 & 385 & 380 & 370 \\
\hline Galinhas & 248.440 & 232.920 & 298.235 & 350.000 & 443.000 \\
\hline $\begin{array}{l}\text { Galos, } \\
\text { frangos, } \\
\text { frangas e } \\
\text { pintos }\end{array}$ & 211.300 & 220.400 & 240.800 & 250.900 & 251.000 \\
\hline Codornas & 1.400 & 1.000 & 950 & 800 & 800 \\
\hline Caprinos & 215 & 170 & 179 & & \\
\hline
\end{tabular}

Fonte: IBGE - Produção Pecuária Municipal.

Os dados da tabela 13 (acima) mostram que a pecuária bovina semi-extensiva mista tem tradição no meio rural de Biguaçu. No entanto, tem ocorrido a diversificação no pequeno 
produtor, através da instalação de novos aviários na produção de ovos e de carne de aves, por meio de sistema integrado com as indústrias da região.

Tabela 14 - Área total dos estabelecimentos agropecuários, segundo a utilização de terras nos municípios de Antônio Carlos e Biguaçu-SC.

\begin{tabular}{|c|c|c|c|c|c|c|c|c|c|c|c|}
\hline & \multicolumn{11}{|c|}{ Área (ha) } \\
\hline & $\begin{array}{c}\mathrm{N}^{\mathrm{o}} \\
\text { est.agrop } \\
\text { inf. }\end{array}$ & $\begin{array}{l}\text { Área } \\
\text { total (ha) }\end{array}$ & $\begin{array}{l}\text { Lav. } \\
\text { Temp. }\end{array}$ & $\begin{array}{l}\text { Lav. } \\
\text { Perm. }\end{array}$ & $\begin{array}{l}\text { Lav. } \\
\text { Desc. }\end{array}$ & $\begin{array}{l}\text { Past. } \\
\text { nat. }\end{array}$ & $\begin{array}{l}\text { Past. } \\
\text { plan. }\end{array}$ & $\begin{array}{l}\text { Cap. } \\
\text { Até } \\
6 \text { anos }\end{array}$ & $\begin{array}{l}\text { Mata } \\
\text { natural }\end{array}$ & $\begin{array}{l}\text { Matas } \\
\text { plant. }\end{array}$ & Outras \\
\hline $\begin{array}{c}\text { Ant. } \\
\text { Carlos }\end{array}$ & 590 & 24440,9 & 1980,9 & 1586,2 & 1229,9 & 3903,5 & 2435,1 & 4383,4 & 6477,6 & 1294,7 & 1149,6 \\
\hline Biguaçu & 418 & 15405,9 & 1919,7 & 467,8 & 172,3 & 3886,5 & 1618,3 & 874,8 & 3950,5 & 1717,9 & 798,1 \\
\hline
\end{tabular}

Fonte: Levantamento Agropecuário de Santa Catarina 2002-2003 (Dados preliminares, fev/05).

Segundo o Levantamento Agropecuário de Santa Catarina (LAC-2005), o município de Biguaçu possui 418 estabelecimentos agropecuários informantes. A área total dos estabelecimentos agropecuários teria 15.405,9 ha. Desse total, as pastagens nativas somam $3.886,5$ ha $(25,22 \%)$ e as pastagens plantadas com $1.618,3$ ha $(10,50 \%)$. Verifica-se que a maioria das terras no meio rural de Biguaçu é ocupada por pastagens, com 5.504,8 ha $(35,72 \%)$ do total de estabelecimentos agropecuários, segundo os dados da tabela 14 (acima). As pastagens ocupam lugar de destaque na área de estudo, principalmente no município de Biguaçu. As pastagens estão presentes nos mais diferentes ambientes, mas é mais comum, na planície fluvial e nas faixas marginais dos rios da bacia em áreas de preservação permanente (APP) (Silva, 2005, p.4139). 


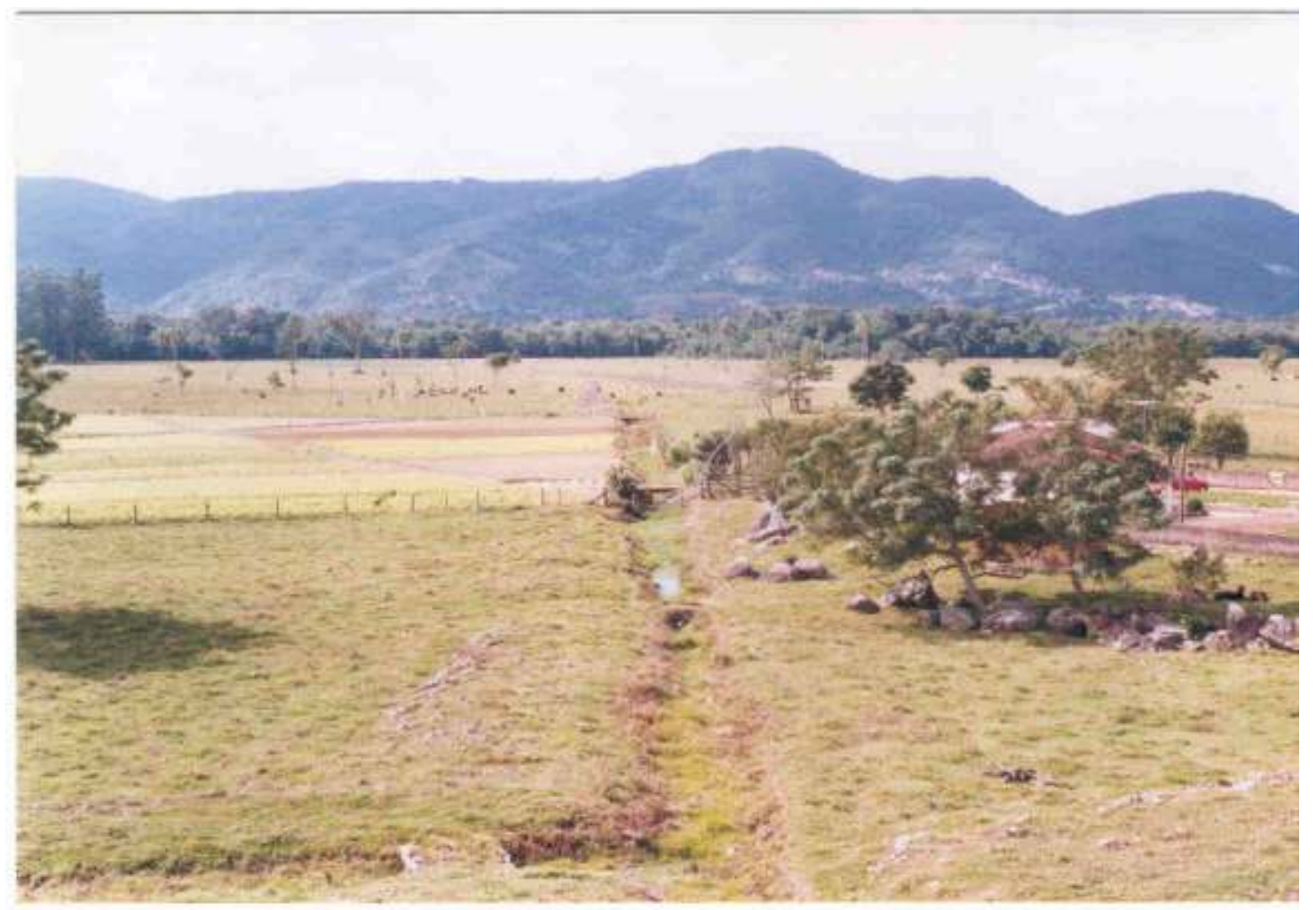

Figura 9 - Planície fluvial do rio Biguaçu. A fundo, Serra de São Miguel.Uso da terra, pastagens, município de Biguaçu-SC. (Foto Ivanete Nardi, maio/2003).

O município de Antônio Carlos possui 590 estabelecimentos agropecuários informantes e a área total é de 24.440,9 hectares. Portanto, possui área total bem superior a de Biguaçu. Em relação ao uso da terra, a área de pastagens é de 6.338,6 ha (25,94\%), tendo área superior ao município de Biguaçu, mas com percentual inferior $(9,78 \%)$. Em relação à cobertura, o destaque é a área com matas naturais, 6.477,6 ha (26,50\%) e capoeiras (até seis anos) com 4.383,4 ha (17,94\%), que somados representam $44,44 \%$ da área total dos estabelecimentos agropecuários informantes. Em Biguaçu os dados da área de matas naturais e de capoeiras até 6 anos, representam 4.825,3 ha (31,31\%). As áreas destinadas aos reflorestamentos em Biguaçu correspondem a 11,15\% e em Antônio Carlos com 5,30\%, conforme dados da tabela 14 . 
Tabela 15 - Produção Agrícola do município de Antônio Carlos-SC

\begin{tabular}{|c|c|c|c|c|c|c|}
\hline $\begin{array}{l}\text { Produtos I } \\
\text { Ano }\end{array}$ & 2001 & 2002 & 2003 & 2004 & $2004^{*}$ & 2005 \\
\hline $\begin{array}{l}\text { Abacaxi } \\
\text { (mil frutas) }\end{array}$ & 48 & 48 & 48 & 48 & & 48 \\
\hline $\begin{array}{l}\text { Arroz em } \\
\text { casca } \\
\text { (ton.) }\end{array}$ & 68 & 68 & 80 & 80 & 80 & 80 \\
\hline $\begin{array}{l}\text { Batata- } \\
\text { doce (ton.) }\end{array}$ & 6000 & 6000 & 6000 & 6.000 & & 6.000 \\
\hline $\begin{array}{l}\text { Batata- } \\
\text { inglesa } \\
\text { (ton.) }\end{array}$ & 45 & 105 & 123 & 123 & & 123 \\
\hline $\begin{array}{l}\text { Cana-de- } \\
\text { açúcar } \\
\text { (ton.) }\end{array}$ & 21700 & 21700 & 17500 & 36 & 20000 & 17.500 \\
\hline $\begin{array}{l}\text { Cebola } \\
\text { (ton.) }\end{array}$ & 24 & 24 & 36 & & & 36 \\
\hline $\begin{array}{l}\text { Feijão em } \\
\text { grão (ton.) }\end{array}$ & 78 & 76 & 78 & 78 & 60 & 78 \\
\hline $\begin{array}{l}\text { Mandioca } \\
\text { (ton.) }\end{array}$ & 5000 & 7500 & 7500 & 3.000 & 3000 & 3.000 \\
\hline $\begin{array}{l}\text { Milho em } \\
\text { grãos }\end{array}$ & 300 & 300 & 525 & 525 & 600 & 525 \\
\hline $\begin{array}{l}\text { Tomate } \\
\text { (ton.) }\end{array}$ & 600 & 600 & 675 & 675 & & 675 \\
\hline 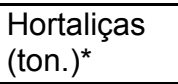 & & & & & 37500 & \\
\hline $\begin{array}{l}\text { Banana } \\
\text { (ton.) })^{*}\end{array}$ & & & & 4.500 & 3000 & 4.500 \\
\hline $\begin{array}{l}\text { Laranjas } \\
{\text { (ton. })^{\star}}^{\text {. }}\end{array}$ & & & & & & 3.600 \\
\hline 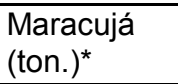 & & & & 225 & 225 & 225 \\
\hline
\end{tabular}

Fonte:IBGE -Pesquisa Agrícola Municipal e Epagri-SC. 
Tabela 16 - Efetivos dos rebanhos do município de Antônio Carlos-SC (unidades)

\begin{tabular}{|c|c|c|c|c|c|c|}
\hline Efetivos & 2001 & 2002 & 2003 & 2004 & 2004* & 2005 \\
\hline Bovinos & 6.910 & 6.094 & 6.126 & 5.500 & 6.126 & 5.600 \\
\hline Suínos & 835 & 1.227 & 1.044 & 1.301 & 946 & 1.320 \\
\hline Eqüinos & 93 & 93 & 92 & 100 & & 100 \\
\hline Bubalinos & & 4 & 4 & & & \\
\hline Coelhos & 9 & 10 & 10 & & & \\
\hline Ovinos & 17 & 45 & 45 & 50 & & 50 \\
\hline Galinhas & 3.380 & 2.010 & 2.120 & 2.300 & 45.000 & 2.350 \\
\hline $\begin{array}{l}\text { Galos, } \\
\text { frangos, } \\
\text { frangas e } \\
\text { pintos }\end{array}$ & 14.000 & 10.100 & 11.230 & 12.180 & & 12.200 \\
\hline \multicolumn{7}{|l|}{ Codornas } \\
\hline Caprinos & 13 & 19 & 19 & & & 25 \\
\hline $\begin{array}{l}(*) \text { Fonte: } \\
\text { Cidasc- } \\
2004\end{array}$ & & & & & & \\
\hline
\end{tabular}

Fonte:IBGE - Produção Pecuária Municipal.

A tabela 16 (acima) refere-se ao rebanho no município de Antônio Carlos, e mostra que áreas destinadas a pastagens são para bovinos. A exploração de aves é reduzida, existindo poucos aviários. Portanto a tradição da agricultura é mantida até hoje, através do cultivo intensivo da terra (tabela 15). A atividade de pecuária no município de Antônio Carlos é secundária, sem grande destaque. 


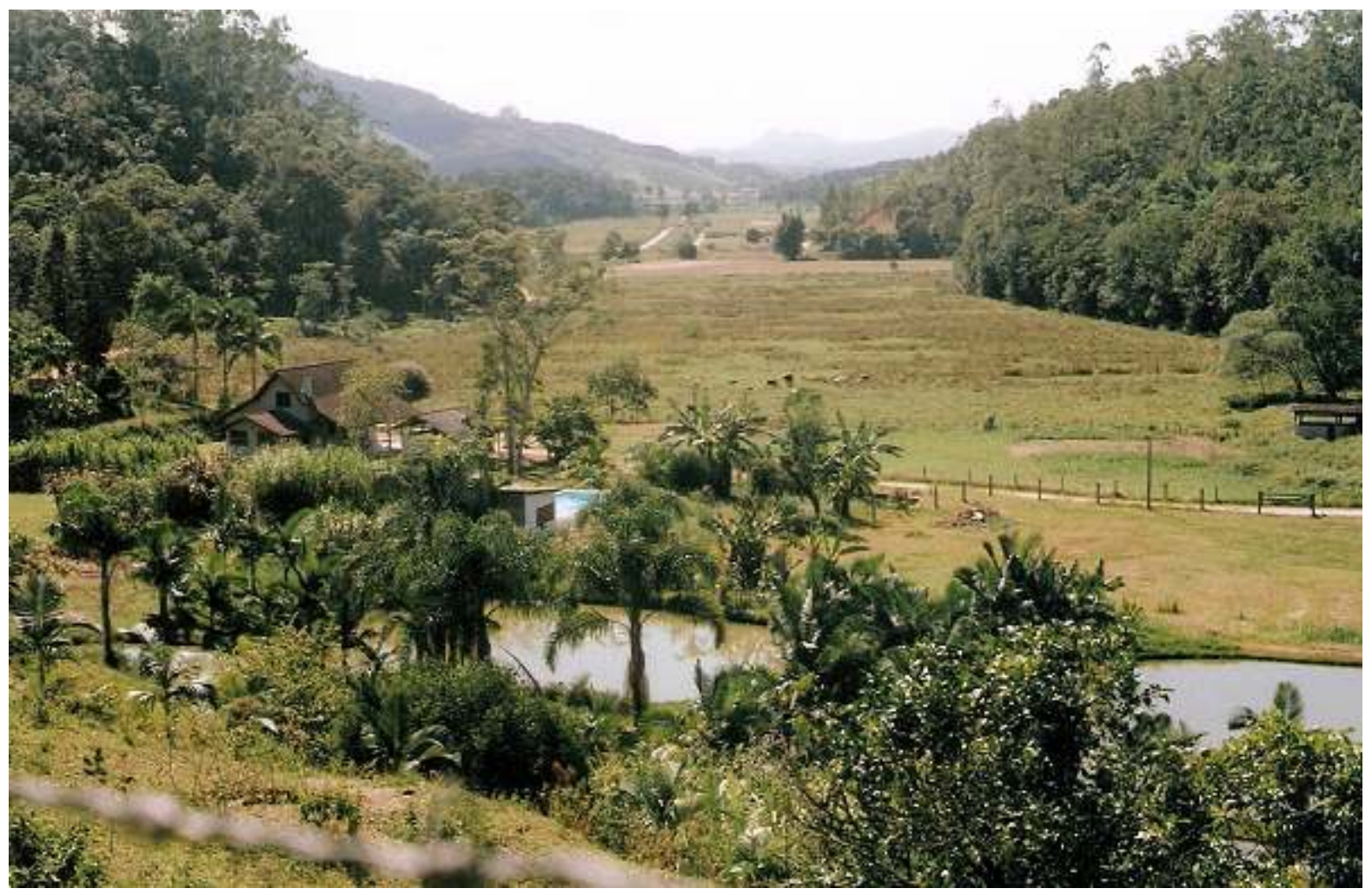

Figura 10: Fundo de vale do Ribeirão Vermelho. Uso da terra com pastagens e plantio de grama, na localidade de Canudos, no município de Antônio Carlos-SC. (Foto: Vicente R. Silva, abril/2006).

A horticultura é uma atividade intensiva, ocupando, em geral, pequenas áreas e a produção é destinada ao abastecimento de mercado urbano (Corrêa; Prates, 1995, p.335). O destino da produção é o Ceasa-SC, em São José, supermercados, sacolões, feiras livres, etc. Em relação à oferta de produtos agrícolas para a Ceasa de São José(SC), em 2004, o município de Biguaçu participou com 7\% da oferta. Já no município de Antônio Carlos, a oferta chegou a 17\%, em conjunto com outros 13 municípios fornecedores. O volume de produção hortifrutigranjeiros comercializados na mesma unidade da Ceasa foi de 6.580 toneladas para Biguaçu, em 2004. Para o município de Antônio Carlos o volume comercializado foi de aproximadamente 16 mil toneladas em 2004 (Henkes, 2006, p.46/59).

O município de Antônio Carlos comercializou em 2004 no Ceasa São José(SC), cerca de 70 produtos diferentes, destacando: agrião, aipim, alface, batata-doce, beterraba, brócolis, cenoura, chuchu, pepino e couve em folha (Henkes, 2006, p.60-61). O município de Biguaçu comercializou em 2004, no Ceasa São José(SC), 53 produtos diferentes, destando os seguintes: abóbora, aipim, alface, banana (branca e caturra), batata-doce, beterraba, cenoura, chuchu, pepino, pimentão, maracujá e tangerina (Henkes, 2006, p.65). 
Segundo o Plano Municipal de Desenvolvimento Rural Sustentável (2005/2008) para o município de Antônio Carlos, na utilização das terras as lavouras temporárias de verão, grãos e hortaliças, ocupam 2.950 ha com $(14,4 \%)$ e as capoeiras 7.950 ha $(38,8 \%)$. Os dados das atividades agrícolas em relação a lavouras permanentes citam a cana-de-açúcar, citrus, banana e maracujá (Santa Catarina, 2005b, p.17-18).

De acordo com informações obtidas no escritório da Epagri, Biguaçu possui 50 produtores de grama (localidade de Santa Cruz) e 50 produtores de arroz irrigado concentrados no vale dos rios Saudade e Três Riachos. Na maioria das vezes, o cultivo de hortaliças está associado ao plantio de grama. No cultivo de hortaliças há problemas de erosão laminar, relacionado ao manejo do solo e na rotativa puxada pelo microtrator tobata, segundo Waldemiro Sudoski (inf. verbal, julho 2005).

$\mathrm{Na}$ bacia do rio Biguaçu, no interior dos municípios de Biguaçu e Antônio Carlos, ocorre intensa exploração agrícola com lavouras de milho, feijão, mandioca, cana-de-açúcar, horticultura, e o cultivo de grama para jardins, associados a áreas de pastagens (Kuerten, 1995, p.6).

\subsubsection{1-Mapa de Ocupação e Uso da Terra - 2006}

$\mathrm{Na}$ bacia do rio Biguaçu, em termos visuais, predomina a ocupação com vegetação secundária, notadamente capoeirões. Nesse aspecto, o município de Antônio Carlos possui as maiores áreas de Floresta Ombrófila Densa. Geralmente os fragmentos de mata atlântica ocupam áreas com altitudes acima de 200 metros e declividade superior a 12\%. As áreas ocupadas por capoeiras e capoeirinhas são bem menores e, em geral, descontínuas e dispersas em todas as subbacias do rio Biguaçu.

O manguezal ocupa área reduzida nas duas margens do rio Biguaçu, junto à desembocadura, na baía norte, do litoral catarinense. O manguezal integra o distrito-sede de Biguaçu. A vegetação de praia é escassa ao longo da faixa da praia de João Rosa $(4 \mathrm{~km})$. As pastagens naturais e plantadas estão dispersas por toda a área de pesquisa. As áreas mais representativas localizam-se ao longo do vale dos rios Biguaçu, Três Riachos e da Guiomar (margem esquerda). No vale do rio Farias (baixo curso) possui grandes áreas de pastagens no município de Antônio Carlos. Também há pastagens e plantio de grama no vale de um 
tributário do rio Biguaçu (margem direita), na localidade Alemanha, no município de Biguaçu.

Geralmente as pastagens de maiores extensões situam-se em área plana, com declividade entre 0 e $3 \%$ e em altitudes inferiores a 20 metros, típico do baixo vale do rio Biguaçu. É comum na bacia as pastagens associadas a lavouras temporárias de arroz irrigado, hortaliças e plantio de grama. As lavouras temporárias têm a maior concentração de áreas junto aos rios da bacia e estradas secundárias municipais que dão acesso ao interior dos dois municípios. É fácil perceber na paisagem a exploração econômica de plantio de grama e hortaliças, em vários trechos da rodovia estadual SC- 408, que liga Biguaçu a Antônio Carlos.

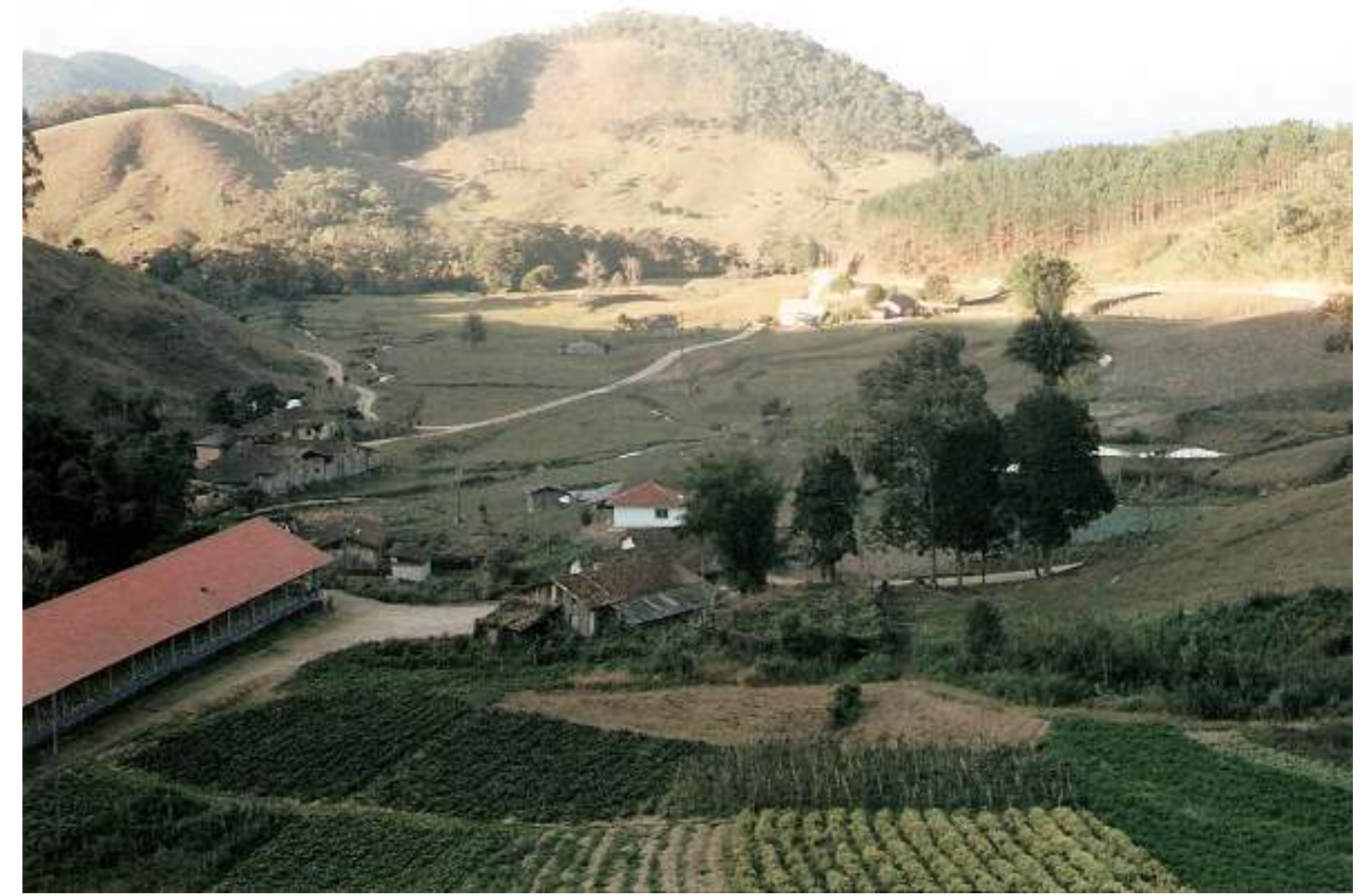

Figura 11: Aspectos do uso da terra, com pastagens, horticultura e eucaliptos no alto curso do rio Biguaçu, na localidade Alto Egito, no município de Antônio Carlos-SC. (Foto: Vicente R. Silva, julho/2006).

A principal atividade econômica do município de Antônio Carlos é o cultivo de hortaliças, sendo considerado o município de maior produção de Santa Catarina. Em Antônio Carlos, apesar de predomínio da pequena propriedade, essa atividade no conjunto das propriedades rurais, chega a explorar cerca de 2540 hectares, da qual dependem 750 famílias (Santa Catarina, 2005, p.18). No vale dos rios Saudade e Três Riachos, (ambos no município 
de Biguaçu), tem destaque o cultivo de arroz por parte de 50 produtores rurais. No vale do ribeirão Vermelho (município de Antônio Carlos) podemos destacar o cultivo de hortaliças e grama, na localidade de Canudos. No vale do rio do Louro, há grandes áreas com cultivo de hortaliças e plantio de grama para jardinagem. No vale do rio Rachadel, parte das terras é utilizada no plantio de hortaliças.

As lavouras permanentes ocupam espaços bem menores na bacia do rio Biguaçu. São cultivados: cana-de-açúcar, banana, citrus e maracujá, no município de Antônio Carlos. Também são cultivadas culturas anuais como hortaliças, milho, mandioca e feijão.

No município de Biguaçu, há 50 produtores de grama para jardinagem concentrados na localidade de Santa Cruz. Os reflorestamentos estão mais presentes em locais com declividade acima de 45\%. Predomina a utilização de eucaliptos nos dois municípios, sendo utilizados na produção de lenha, carvão e escorra para construção civil.

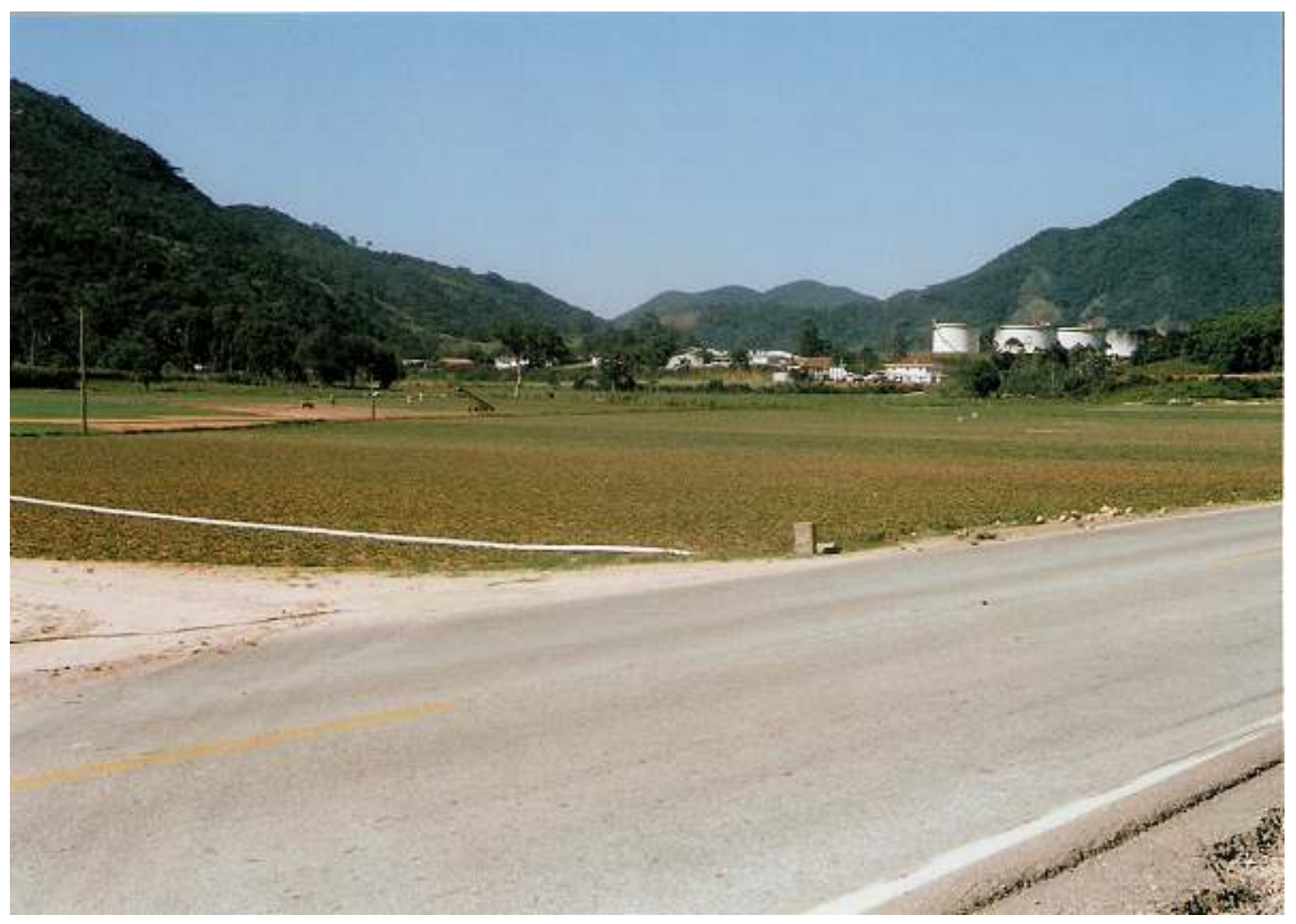

Figura 12: Plantio de grama as margens da SC-408 e ao fundo a Base da Petrobras na localidade Santa Cruz, município de Biguaçu - SC. (Foto:Vicente R. Silva, março/2006) 
A cidade de Antônio Carlos situa-se no médio vale do rio Biguaçu. A única indústria de grande porte é a Vonpar (fábrica de refrigerantes e cerveja), localizada as margens da SC408. Já o município de Biguaçu possui um número bem maior de indústrias, com destaque ao setor químico (material plástico). Segundo dados obtidos na Biblioteca Municipal Teixeira de Oliveira no centro de Biguaçu, possui 92 indústrias, destacando a Inplac, Luplast, Plasc, Termopack, Sulcatarinense, Marmoria Biguaçu, Cequipel e Granja Áurea. Sua localização geográfica é bastante favorável à instalação de unidades industriais, pois a BR-101, corta a cidade no sentido norte-sul. 


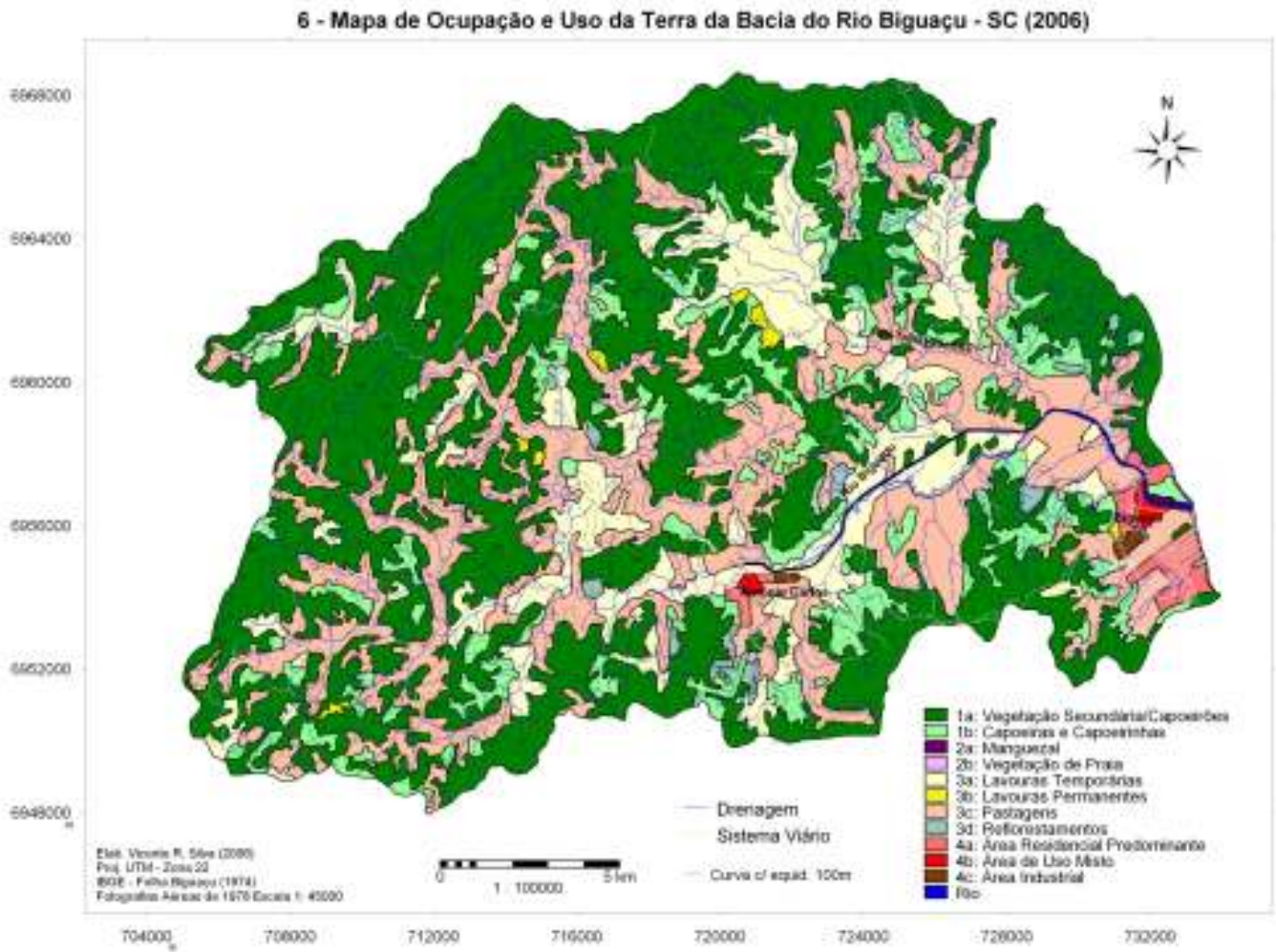

Figura 13 - Mapa de ocupação e uso da terra da bacia do rio Biguaçu-SC. 


\section{3-O AMBIENTE NATURAL}

\subsection{1-Características Geológicas}

Geologia da bacia do Rio Biguaçu.

Em termos regionais, o panorama geológico da região Sul do Brasil é constituído por três grandes domínios geológicos: Terrenos Pré-Cambrianos, Bacia do Paraná e Cobertura de Sedimentos Cenozóicos. O domínio do Pré-Cambriano é formado por grande variedade de tipos de rochas, formadas desde os primórdios dos tempos geológicos (de 3 bilhões de anos atrás até + 500 milhões de anos). Trata-se de rochas ígneas granitóides, rochas metamórficas de origem ígneas e sedimentares, de composição química diversificada. Ocorre também, seqüência de cobertura de natureza vulcano-sedimentar (Kaul, 1990, p.29).

O Pré-cambriano é dividido em cráton e cinturões móveis. No caso do presente estudo, pertence ao Cinturão Móvel Dom Feliciano, que corresponde a porção oriental do planalto sul-rio-grandense e terrenos pré-cambrianos do sul de Santa Catarina(op. cit.). Já o domínio da Bacia do Paraná é o mais amplo domínio geológico do Sul de Brasil, implantado em terrenos Pré-Cambrianos a partir do Siluriano Inferior (op.cit.). Na bacia, o domínio da Bacia do Paraná ocorre em áreas bem restritas, pertencentes à Formação Serra Geral, do Grupo São Bento. Localmente com formas de leques de diabásio, preenchendo falhas e fraturas. O Cinturão Móvel Dom Feliciano é composto pelo Complexo MetamórficoMigmático, distribuído no Rio Grande do Sul e Santa Catarina (Kaul, 1990, p.35).

O autor citado acrescenta que a zona central desse cinturão é uma faixa linear composta por rochas gnáissicas, migmáticas e graníticas. “As rochas graníticas aparecem intimamente associadas às rochas migmáticas, sendo sin ou tardiorogênicas” (Kaul, 1990, p.36). Dentre as várias intrusões graníticas, temos a Suite Intrusiva Valsungana, temos o granito Congonhas, que ocorre no extremo oeste da bacia do rio Biguaçu (Fortes, 1996, p.26).

\section{Complexo Metamórfico-Migmático}

O Complexo Metamórfico-Migmático possui as rochas mais antigas conhecidas do escudo catarinense, de idade Pré-Cambriana (Trainini et al.,1978, p.213). De acordo com Trainini et al (1978) apud Pires; Coitinho; Freire; Fernandes (1997, p.7), o Complexo Canguçu que está presente na área da Grande Florianópolis, engloba parcialmente o 
Complexo Metamórfico-Migmático. Os migmatitos têm coloração acinzentada, com granulação variando entre fina e grosseira, que ocorre na região do município de Antônio Carlos. Carvalho (1932) é a referência mais antiga sobre as rochas componentes do embasamento cristalino antigo de Santa Catarina, que denominou de Complexo Cristalino. Na década de 1970, Trainini et al (1978), deu nova denominação passando para Complexo Metamórfico-Migmático. As massas rochosas do Complexo Ganguçu ocorrem de forma alongada, de direção NE- SW ou NNE- SSW, estendendo-se desde Balneário Camboriú até o paralelo $27^{\circ} 30^{\prime}$ de latitude Sul. Em geral, faz contato por falhas com a Suite Intrusiva São Pedro de Alcântara, Valsungana e com coberturas sedimentares quaternárias (Kaul; Fernandes; Santos Neto, 2003, p.16).

O Complexo Metamórfico-Migmático faz contato a leste com a Suite Intrusiva Pedras Grandes e a oeste é interrompida pela Suite Intrusiva Valsungana (Fortes, 1996, p.26). Na área de pesquisa da bacia do rio Biguaçu serão usados como base os trabalhos de Trainini et al (1978), que realizou mapeamento de grande parte da bacia e complementada no mapa de geologia por Fortes (1996).

Para Trainini et al (1978), a área de nosso estudo é formado por rochas do Précambriano e tem três unidades geológicas distintas: o Complexo Metamórfico-Migmático; a Suite Intrusiva Valsungana e a Suite Intrusiva Pedras Grandes. Do mesozóico afloram os diques de diabásio da Formação Serra Geral. As rochas ígneas e metamórficas encontram-se modeladas em elevações de altitudes entre 40 e 880 metros. Os terrenos mais elevados têm a denominação de serras (Fortes, 1996, p.25).

\section{Suite Intrusiva Valsungana}

A denominação atual do termo 'suite intrusiva' para designar essa unidade de rochas magmáticas, deve-se a Trainini et al (1978). No projeto Gerco ( $3^{\mathrm{a}}$ fase), no estudo de geologia, essa suite é representada por dois corpos intrusivos maiores. Desses corpos, o maior estende por cerca de $1.000 \mathrm{~km}^{2}$, e o menor por $250 \mathrm{~km}^{2}$. Para os autores do IBGE, a única intrusiva que faz contato como o Grupo Brusque se localiza ao Sul da área do projeto, estando inserida quase totalmente no Complexo Canguçu (Complexo MetamórficoMigmático), da qual está separada por falhas (Kaul; Fernandes; Santos Neto, 2003, p.18). 
Segundo Trainini et al (1978), essa suite se constitui em diversos granitóides de composição predominante granodiorítica, com variações para termos graníticos, quartzomonzoníticos e quartzo-dioríticos (Pires; Coitinho; Freire; Fernandes,1997,p.9). Em outro trabalho, na mesma região, geólogos argumentam que a Suite Intrusiva Valsungana está associada ao granito Santa Filomena, que ocorre na Serra de Santa Filomena entre as localidades de São Pedro de Alcântara e Antônio Carlos (Coitinho; Fernandes; Issler,1981 apud Pires; Coitinho; Freire; Fernandes (1997, p.9).

Localmente, na bacia do rio Biguaçu, a Serra de Santa Filomena situa-se na porção sudoeste e oeste, servindo de limites da referida bacia. A Suite Intrusiva Valsungana é constituída por variados tipos de rochas, no entanto, somente o granito Congonhas está presente na bacia. Essa unidade mostra-se, com freqüência diaclasada e faz contato por falhas com as rochas do Complexo Metamórfico-Migmático Trainini et al. (1978) apud Fortes (1996, p.26).

O granitóide Valsungana “ocorre principalmente na forma de lajeados e em corte de estrada, estando na metade dos casos, intemperizados. Às vezes, forma matacões da ordem de um a três metros de diâmetro” (Trainini et al., 1978, p.72).

\section{Suite Intrusiva São Pedro de Alcântara}

Essa unidade litoestratigráfica foi proposta por Basei (1985). Na área do projeto Gerco ( $3^{\mathrm{a}}$ fase), é representada por um corpo alongado de direção NE-SW, com cerca 80 km2, fazendo contato por falhas com as Suites Intrusivas Pedras Grandes, Valsungana e o Complexo Ganguçu. Há também dois corpos bem menores, um situado ao norte da cidade de Biguaçu, limitado pela linha de costa, e por sedimentos quaternários; o outro corpo menor está situado a $10 \mathrm{~km}$ a oeste da cidade de Biguaçu. Esse último corpo apresenta contornos irregulares, quase inteiramente rodeado por sedimentos quaternários, apenas em sua porção norte, faz contato intrusivo com o Complexo Ganguçu (Kaul, Fernandes, Santos Neto, 2003, p.19). A Suite Intrusiva São Pedro de Alcântara foi considerada por Trainini et al. (1978), como pertencente ao Complexo Metamórfico-Migmático.

\section{Suite Intrusiva Pedras Grandes}

A terminologia Pedras Grandes foi utilizada primeiramente por Teixeira (1969), para designar um complexo de certos corpos graníticos homogêneos do leste de Santa Catarina: 
Complexo Pedras Grandes. Mais tarde, sua denominação foi alterada para Suite Intrusiva Pedras Grandes em pesquisas realizadas por Trainini et al. (1978). De acordo com estudos de Fortes (1996), essa suite possui vários tipos de granitos, porém, na bacia do rio Biguaçu, apenas o granito São Miguel está presente, com predomínio de rochas graníticas, com variações de quartzomonzonito e granodiorito, de cor cinza a rosa, com pontuações pretas de biotita, essencialmente leucocrática, (...) Trainini et al. (1978) apud Fortes (1996, p.27).

Essa unidade aflora na porção leste da bacia do rio Biguaçu, sendo conhecida por Serra de São Miguel. Ela faz contato com sedimentos quaternários, próximo a mar. O granito São Miguel apresenta contato a oeste, por falhas com os migmatitos do Complexo Metamórfico-Migmático e ao sul com os depósitos quaternários (Fortes, 1996, p.27-28). No projeto Gerco (3afase), o granito São Miguel tem área de 60 km2, porém os geólogos do IBGE, o incluem na Suite Intrusiva Tabuleiro (Kaul ; Fernandes; Santos Neto, 2003, p27).

Bacia do Paraná

\section{Formação Serra Geral}

$\mathrm{Na}$ área de estudo, essa formação está presente na forma de diques de diabásio, que preenchem falhas e fraturas na porção oeste da bacia, no alto vale do rio Rachadel, possuindo direção Norte-Sul. Os diques estão em fraturas abertas nos metatexitos do Complexo Metamórfico-Migmático (Fortes, 1996, p.39).

\section{Cobertura Sedimentar Cenozóica}

A cobertura sedimentar cenozóica é formada por diferentes tipos de depósitos sedimentares, com idade variando de terciária a holocênica. Esses depósitos podem ser de origem fluvial, marinha, lagunares, eólicos e coluvial. Os sedimentos fluviais ocupam as calhas dos rios atuais, sendo constituídos por cascalhos, silte e argilas. Os sedimentos marinhos são representados pelas praias atuais. Os depósitos praiais são areias finas, relacionadas, localmente, com concentração de minerais pesados (Kaul, 1990, p.42).

\section{Sedimentos Plestocênicos}

Sedimentos Colúvio Aluvionares Continentais - Englobam tanto terraços arenosos antigos como depósitos de pé de encosta e os aluviões subatuais. Em geral, são formados por alternância de níveis de lentes arenosas e argilosas, mal selecionadas, com presença freqüente 
de horizontes de seixos e calhaus, os quais se tornam mais expressivos, próximo às áreas fontes (Kaul; Fernandes, Santos Neto, 2003, p.35).

\section{Sedimentos Holocênicos}

Areias, cascalheiras e sedimentos siltico-argilosos, inconsolidados, depositados em planície de inundação, terraços e calhas da rede fluvial atual.

\section{Sedimentos Colúvio-Aluvionares}

Depósitos de colúvio-elúvio e aluviões recentes, constituídos por sedimentos inconsolidados, com grande variação granolométrica, incluindo depósitos areno-argilosos e areno-síltico argilosos, com estratificação incipiente ou ausente, incluindo depósitos “in situ” (Kaul; Fernandes; Santos Neto, 2003, p.36). Na bacia do rio Biguaçu, há registro da existência de pequenas rampas localizadas próximo a cidade de Biguaçu. Os sedimentos coluviais ocorrem a partir da média encosta das serras até o contato com os depósitos fluviais (Fortes, 1996, p.90).

\section{Sedimentos Fluvio-Marinhos}

Trata-se de material siltico-argiloso, sobrepostos a depósitos de areias marinhas, comumente cobertos por camadas de matéria orgânica (Kaul; Fernandes; Santos Neto, 2003, 37). Esse tipo de depósito forma a praia de João Rosa, em Biguaçu. Esse depósito lamítico é colmatado pelo rio Biguaçu, em frente a referida praia, ficando totalmente exposto durante a maré baixa, podendo recobrir o setor norte da praia (Fortes, 1996, p.64).

\section{Sedimentos Marinhos Atuais}

São constituídos por cordões de areia bem selecionados de cores claras, creme a amareladas, que se distribuem ao longo das praias atuais (Kaul; Fernandes; Santos Neto, 2003, p.37). A praia de João Rosa possui cerca de 4 km de extensão, com direção norte-sul. Trata-se de uma praia arenosa com recobrimento de lama em alguns locais. Essa praia atual situa-se entre a foz do rio Biguaçu (norte) e um afloramento rochoso para o sul. A planície costeira de Biguaçu apresenta uma sucessão de cristas praiais, formada por faixa arenosa, localizada entre a praia atual a leste e os depósitos fluviais e terrenos cristalinos a norte, oeste e sul. A planície costeira tem área total de 6,48 km² (Fortes, 1996, p.61-65). 


\section{Sedimentos Argilo-Síltico-Arenosos}

Depósitos ricos em matéria orgânica que sofrem influência das marés e são típicos dos mangues atuais. Localmente representado pelo manguezal na foz do rio Biguaçu, na cidade de Biguaçu. São denominados de depósitos paludais as áreas desse ecossistema, nas laterais do baixo curso do rio Biguaçu (Fortes, 1996, p.80).

\section{Recursos Minerais}

\section{Areias Quartzosas}

São sedimentos de granulação arenosa, formados por quartzo (97 a 99\%), utilizados na fabricação de vidros, cristais, na indústria cerâmica como esmalte cerâmico, como abrasivo e na confecção de moldes de fundição. As principais ocorrências são encontradas nos vales dos rios (Kaul; Fernandes; Santos Neto, 2003, p.41). A presença de duas dragas foi constatada por nós, durante a realização de trabalho de campo no rio Biguaçu, a montante da cidade de Antônio Carlos. Próximo à foz do rio Três Riachos há a mina Saudade, que explora areia da margem direita do rio Biguaçu. Essa atividade mineradora localiza-se no interior do município de Biguaçu.

\section{Granito Industrial}

Os granitos são rochas de maior distribuição no leste de Santa Catarina e estão agrupados em diferentes unidades litoestratigráficas, de acordo com suas características mineralógicas, química e texturais etc. São matéria-prima para a construção civil, onde são utilizados como brita, material de revestimentos, blocos, mourões etc (Kaul; Fernandes; Santos Neto, 2003, p.45). Em Biguaçu, há uma pedreira de granito que pertence à Suite Intrusiva Pedras Grandes, na serra de São Miguel, na localidade de Saudades.

\section{Saibro}

Os diversos batólitos graníticos presentes na área do projeto Vidal Ramos-Biguaçu, quando alterados, prestam-se para extração de saibro. Os locais típicos são as zonas de alteração do Granito São Miguel e do granitóide Valsungana (Trainini et al., 1978, p.237).

Em Biguaçu ocorre a produção de brita, areia e saibro (agregados para a construção civil). O saibro é formado pela “decomposição parcial de rochas graníticas, contendo uma mistura de material granular com dimensões de areia média a grosseira, compostos por 
quartzo e feldspato, acrescidos de silte e argila” (Pires, 2000, p.69). A produção é quase toda informal, com exploração dispersa, de natureza temporária e efêmera, não permitindo a fiscalização de órgãos competentes (op. cit.). O saibro é denominado material de empréstimo.

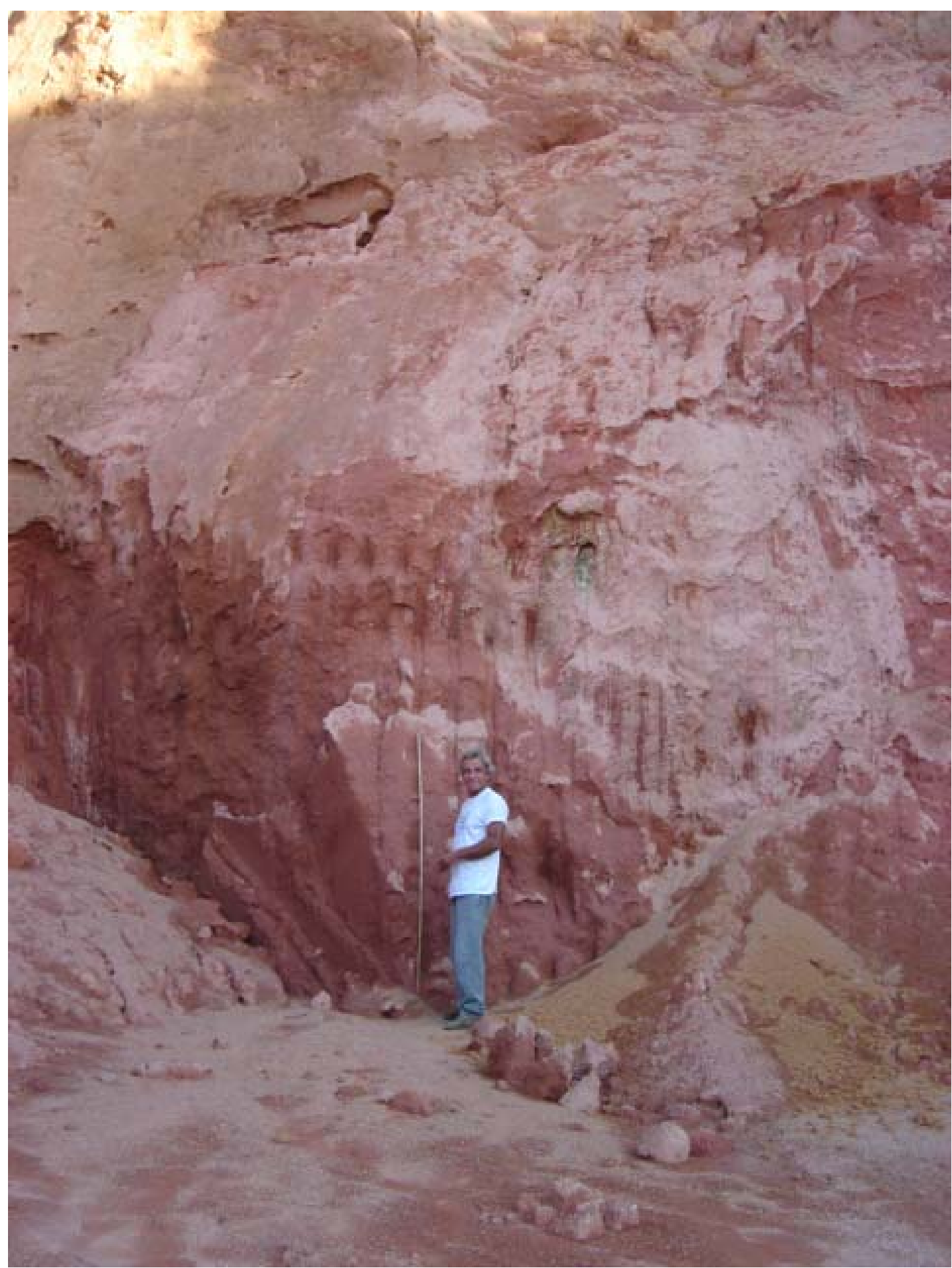

Figura 14 - Vista em detalhe de afloramento de elúvio com cerca de $40 \mathrm{~m}$. de espessura, na localidade Guiomar, município de Antônio Carlos-SC. Foto: Vicente R. Silva, março/ 2007. 
A atividade de extração de saibro ocorre nos dois municípios da bacia, conforme foi constatado por nós em trabalhos de campo. Essa extração pode ocorrer em diferentes formas de relevo, provocando uma disseminação de frentes de extração, com precariedade de técnicas de lavras, gerando áreas de degradação ambiental e de riscos geotécnicos (Pires, 2000, p.69).

A exploração de argila na bacia do rio Biguaçu não se destaca, em função da pouca disponibilidade de matéria-prima. Em geral, as saibreiras estão próximas a rodovias e estradas não pavimentadas. Os depósitos, em geral, são do tipo residuais ou de alteração “in situ”, associadas às rochas graníticas. O saibro é destinado a pavimentos de estradas, aterros e como base no plantio de grama.

\subsubsection{1-Mapa Geológico}

A bacia do rio Biguaçu está sob domínio dos terrenos pré-cambriânicos. Localmente, são dominantes as rochas do Complexo Metamórfico-Migmático, que representam cerca de 70\% da total área de estudo, ocorrendo de forma alongada, com direção preferencial de NESW. O tipo pEcmt, representa a maior área ocorrendo desde o extremo nordeste até o extremo sudoeste da bacia. O segundo tipo, pEcd, ocorre na porção central até o sul, bem como, uma área menor a sudeste da área pesquisada. O pEcd faz contato com os sedimentos do quaternário fluvial dos rios Saudade, Três Riachos e Biguaçu. O Complexo MetamórficoMigmático faz contato através de falhas com a Suíte Intrusiva Pedras Grandes a leste e a oeste e com a Suíte Intrusiva Valsungana.

A Suíte Intrusiva Valsungana é representa localmente pelo granito Congonhas (Serra das Gongonhas, Serra do Major e Serra do Macaco Branco). Trata-se da região com as maiores altitudes da bacia, chegando até 885 metros, próximo ao limite da bacia hidrográfica. É o local dos canais de cabeceiras dos rios Biguaçu, Farias e Rachadel.

A Suíte Introsiva Pedras Grandes (pEsp), situa-se a leste da bacia (município de Biguaçu), sendo conhecida como Serra de São Miguel. Faz contato a leste, oeste e sul com os sedimentos do quaternário fluvial (Qf) e quaternário marinho (Qm). Essa Suíte faz ainda, contato por falhas com as rochas do Complexo Metamórfico-Migmático a noroeste. 


\section{Cobertura Sedimentar Cenozóica}

Quaternário Fluvial - É representado por areias, cascalhos e sedimentos siltico-argilosos inconsolidados que foram depositados na planície de inundação, terraços e calhas da rede fluvial atual. As principais áreas do quaternário fluvial (Qf) são formadas pela planície fluvial dos rios: Biguaçu, Saudade, Três Riachos, Farias, Rachadel, do Louro e ribeirão Vermelho. Os sedimentos fluviais fazem contato com o Complexo Migmórfico-Migmático (maior área) e com a Suíte Intrusiva Pedras Grandes.

Quaternário Marinho - São as praias atuais formadas por areias bem selecionadas. A praia de João Rosa localiza-se entre a foz do rio Biguaçu ao norte e um afloramento rochoso ao sul, próximo ao Morro da Bina. Fazem contato com os depósitos fluviais e terrenos cristalinos da Suíte Intrusiva Pedras Grandes, ao norte, oeste e sul. 


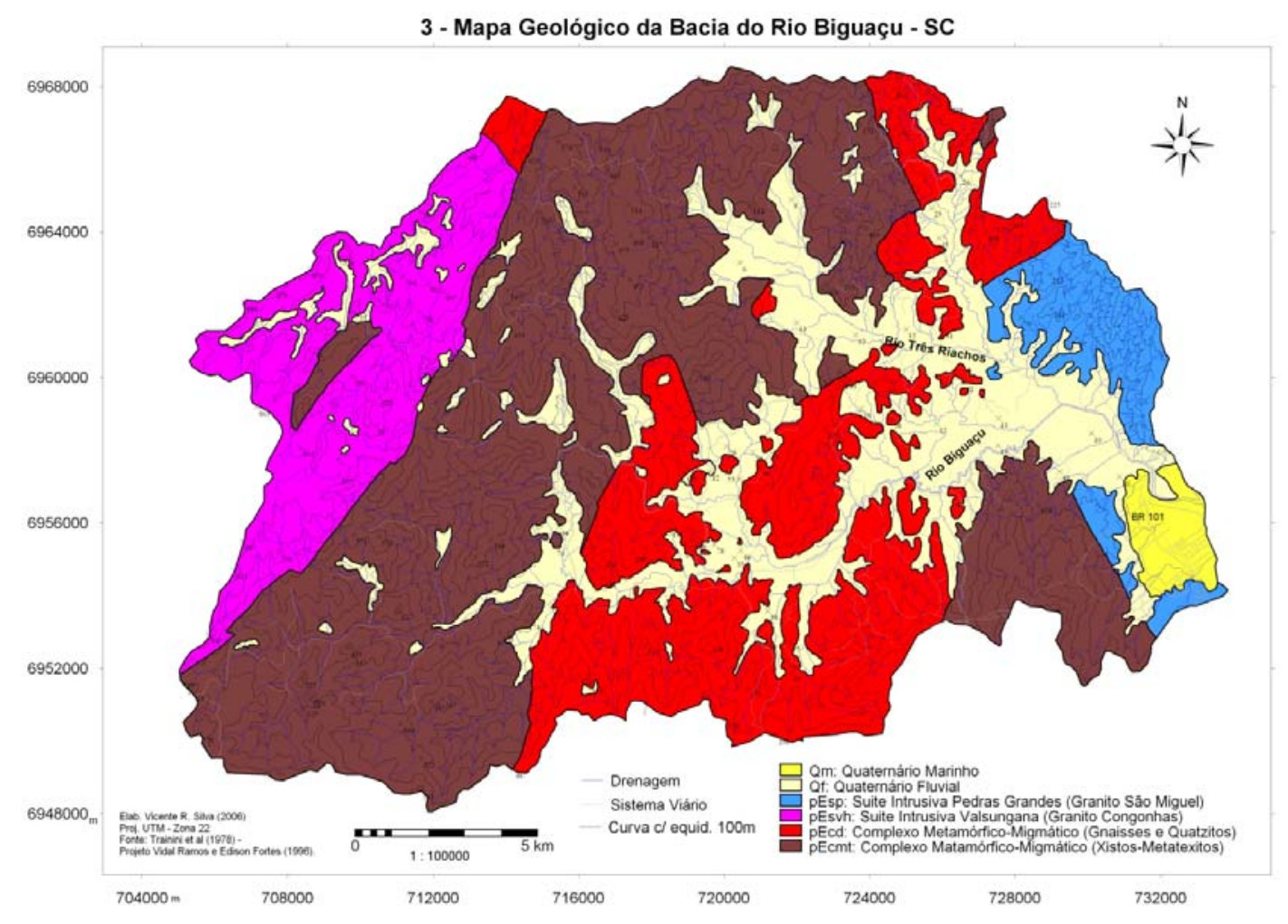

Figura 15 - Mapa Geológico da bacia do Rio Biguaçu-SC 


\subsection{2-Características geomorfológicas}

\section{Geomorfologia da Bacia do rio Biguaçu}

A área correspondente à bacia hidrográfica do rio Biguaçu é representada por dois conjuntos geológicos distintos: o embasamento cristalino e os depósitos quaternários. Segundo Fortes (1996), o primeiro corresponde ao modelado de dissecação e o segundo de acumulação.

A variada composição litológica, bem como, os alinhamentos estruturais e as características climáticas, possibilitaram uma grande variedade de feições geomorfológicas, estas decorrentes de processos morfogenéticos atuais e pretéritos.

De acordo com Trainini et al. (1978), o embasamento cristalino da área do presente projeto apresenta quatro unidades geológicas distintas: o Complexo Metamórfico-Migmático, a Suite Intrusiva Valsungana, Suíte Intrusiva Pedras Grandes e diques de diabásio da Formação Serra Geral. Os últimos constituem a única unidade que não é enquadrada no embasamento cristalino do Pré-Cambriano, sendo de idade Mesozóica.

As litologias características do Complexo Metamórfico-Migmático correspondem aos gnaisses e migmatitos. Os migmatitos apresentam composição quartzomonzonito, granodiorito, granito, ortoanfiobolito, metagabro, microdiorito, metabasito, metadiorito, quartzodiorito, gnaisses, biotita-quartzo-plagioclásio-gnaisse, biotita-gnaisse-quartzofeldespático, biotita-gnaisse, silimanita-moscovita-biotita, quartzo-xisto e granada-biotitaxisto-quartzo-feldespático (Trainini, et al.,1978).

Segundo Fortes (1996), os terrenos do Complexo Metamórfico-Migmático, representados pelos gnaisses localizados na área central da bacia e dispostos na direção NESW, encontram-se mais dissecados que os migmatitos da mesma suíte intrusiva. Estes localizam-se na metade oeste e parte da bacia com a mesma disposição que os gnaisses que formam parte das Serras da Santa Filomena, da Guiomar e São Miguel, sendo que as altitudes variam de 200 a $300 \mathrm{~m}$.

As rochas que compõem a Suíte Intrusiva Valsununga são variadas e delas apenas o granito congonhas está presente na área. O granito congonhas corresponde a um quartzomonzonito, com variações a granito e granodiorito, de cor rosa (com pontuações pretas 
devido a biotita), às vezes cinza-claro. Essa unidade mostra-se freqüentemente cataclasada e faz contato por falha com rochas do Complexo Metamórfico-Migmático (Trainini et al., 1978).

Esta unidade corresponde a um corpo ígneo alongado de direção NE-SW, localizado no setor oeste da bacia; representa a área menos dissecada com altitudes que variam de 800 a 885 m. A resistência dos granitos, que constituem os materiais desse corpo intrusivo, dificulta a formação de cicatrizes de dissecação. Estas, encontram-se presentes apenas na parte sul, estando neste caso associadas a falhas de direção $\mathrm{N} 50^{\circ} \mathrm{E}$ e $\mathrm{N} 65^{\circ} \mathrm{W}$. As altitudes e as resistências das rochas que compõem a Suíte Intrusiva Valsununga controlam os processos de dissecação dos migmatitos do Complexo Metamórfico-Migmático, localizados a oeste (Fortes, 1996).

A Suíte Intrusiva Pedras Grandes está representada na área apenas pelo granito São Miguel, que apresenta variações quartzomonzoníticas e granodioríticas de cor cinza a rosa com pontuações pretas de biotita. Freqüentemente, apresenta orientações cataclásticas, com granulação média a grosseira (Trainini, et al., 1978). Essa unidade aflora na porção leste da bacia hidrográfica do rio Biguaçu, próximo ao mar, na área correspondente a Serra de São Miguel.

Segundo Fortes (1996), a Suíte Intrusiva Pedras Grandes corresponde aos terrenos mais dissecados, normalmente com declividade acentuadas (superiores a 25\%) e menores em relação aos terrenos localizados a oeste. As áreas cristalinas da bacia constituem os locais de nascentes de todos os rios que drenam a bacia, sendo que estes são perenes na sua maioria, ocorrendo pequenos trechos intermitentes nos altos cursos. A rede de canais fluviais da bacia apresenta grande variedade de formas, ligadas à constituição litológica, estrutural e climática da área.

Na obra Geografia do Brasil sobre a Região Sul, editada pelo IBGE, os autores do capítulo sobre o relevo, enquadram a bacia do rio Biguaçu na "Unidade de relevo Serra do Leste Catarinense” (Herrmann; Rosa, 1990, p.76). Esses autores ao fazer referências de seus médios e baixos cursos, assim descrevem: "as vertentes de forte declividade que balizam as nascentes cedem lugar a vertentes mais suavizadas, dissecadas em forma mamelonares e 
colinas esbatidas, isoladas umas das outras por planos aluviais com aspecto brejoso" (Herrmann; Rosa, 1990, p.77).

Fortes (1996), distingue no modelo de acumulação, correspondente aos depósitos quaternários, áreas de sedimentação transicional, flúvio-transicional, fluvial, coluvial e feições eluviais.

As áreas de sedimentação transicional estão representadas pela praia atual e pelas cristas praiais. A primeira apresenta uma extensão de $4 \mathrm{~km}$ com largura variando de $5 \mathrm{~m}$ a 8 m e possui estratificação plano-paralela, horizontal e subhorizontal, inclinando para leste. As cristas praiais formam uma planície com aproximadamente $6,48 \mathrm{~km}^{2}$, sendo que em perfil corresponde a um plano suavemente inclinado em direção ao mar. Encontram-se sulcadas por 38 cristas praiais com altura que ultrapassam 1,00 metro. A altitude de 2,24 metros dessa planície indica oscilações negativas do nível marinho no Holoceno (Fortes, 1996, p.65-69).

As áreas de sedimentação flúvio-transicional estão representadas pelas barras de desembocadura do rio Biguaçu e pelos depósitos paludiais. A barra de desembocadura constitui um depósito (com 1000 m de comprimento e 700 m de largura), em forma de coroa, que avança cerca de 23,5 m/ano para dentro da Baía Norte. O desenvolvimento dessa barra é atribuído à intervenção antrópica ao longo da bacia, através de obras de retificação dos principais canais fluviais e do modelo de ocupação e exploração econômica da área. Os depósitos paludiais correspondem aos manguezais ribeirinhos localizados nas laterais dos baixos cursos dos rios Biguaçu e Caveiras, atualmente descaracterizados por aterros e intensa ocupação humana (op. cit.).

De acordo com o referido autor (op.cit.), as áreas de sedimentação fluvial, estão representadas por pequenos leques aluviais, nas margens oeste, sul e norte da bacia, com deposição de características da parte proximal e mediana. Os depósitos distais se dispõem ao longo do canal principal que os têm escoado e retrabalhado, redepositando como depósito de planície de inundação. Esta faixa, dominada pelo canal principal, mostra uma declividade de cerca de 2\%. Outros depósitos fluviais estão presentes na bacia hidrográfica do rio Biguaçu e foram denominados de “depósitos fluviais confinados", por encontrarem-se em áreas embaciadas, em cotas de 700 a 800 metros de altitude e com declividades da ordem de $2 \%$ a $5 \%$. 
Esses “depósitos fluviais confinados” situam-se entre os topos mais elevados da Serra do Major e Serra do Macaco Branco, que pertence a unidade geomorfológica Planalto de Cimeira.

As áreas de sedimentação coluvial foram identificadas por Fortes (1996), nas proximidades da localidade de Biguaçu e na Serra do Major a oeste, ocorrendo a partir da média encosta das serras. Os elúvios que têm ocorrência generalizada na paisagem correspondem a espessos mantos de alteração de formas convexas nas áreas da baixa encosta. Alguns elúvios ainda apresentam as estruturas das rochas que lhe deram origem, como veios e feições de cataclase.

O relevo da bacia do rio Biguaçu, permite a compartimentação em duas unidades de modelados: a) modelado de dissecação (associado ao embasamento); b) modelado de acumulação (depósitos sedimentares). O modelado de dissecação é representado pelas serras, com vertentes alongadas, com forte amplitude de relevo, podendo ter mais de $25 \%$ de declividade. Os terrenos cristalinos têm superfície de 296,03 km², ou seja, 75,97\% da área total da bacia. Desses, cerca de 40,3\% de terrenos cristalinos têm declividade superior a 25\%; b) $16,8 \%$ entre $10 \%$ a $25 \%$; c) $13,1 \%$ entre $5 \%$ e $10 \%$; d) $6,3 \%$ entre $2 \%$ e $5 \%$; e) $23,4 \%$ com declividade inferior a $2 \%$.

As serras das Congonhas, do Major e do Macaco Branco são as áreas das nascentes de alguns dos principais rios da bacia, dispostos na direção geral NE-SW, seguindo os principais alinhamentos estruturais. A Suíte Intrusiva Valsungana, corpo alongado, localizado no setor oeste da bacia e disposta na direção NE-SW, com áreas menos dissecadas e altitudes variando de 800 a 885 metros. O Complexo Metamórfico-Migmático, localizado no extremo oeste e na área central da bacia. A Suíte Intrusiva Pedras Grandes, localizada na parte leste da bacia, mais próxima ao mar. São terrenos mais dissecados entre todos, que pertence a Unidade Geomorfológica de São Miguel. Predomina declividade superior a 25\%, com altitudes menores (média 300 metros), do que os terrenos localizados no oeste. O relevo é mais rebaixado (Fortes, 1999, p.23-24). O modelado de acumulação corresponde a áreas com declividade de $2 \%$ a $5 \%$ ou inferior a $2 \%$. Abrange áreas de $93,67 \mathrm{~km}^{2}$, ou seja, $24,03 \%$ da superfície total da bacia. As planícies são as formas dominantes de relevo, sendo modeladas em sedimentos arenosos e areno-argilosos (Rosa, 1995, p.7). 


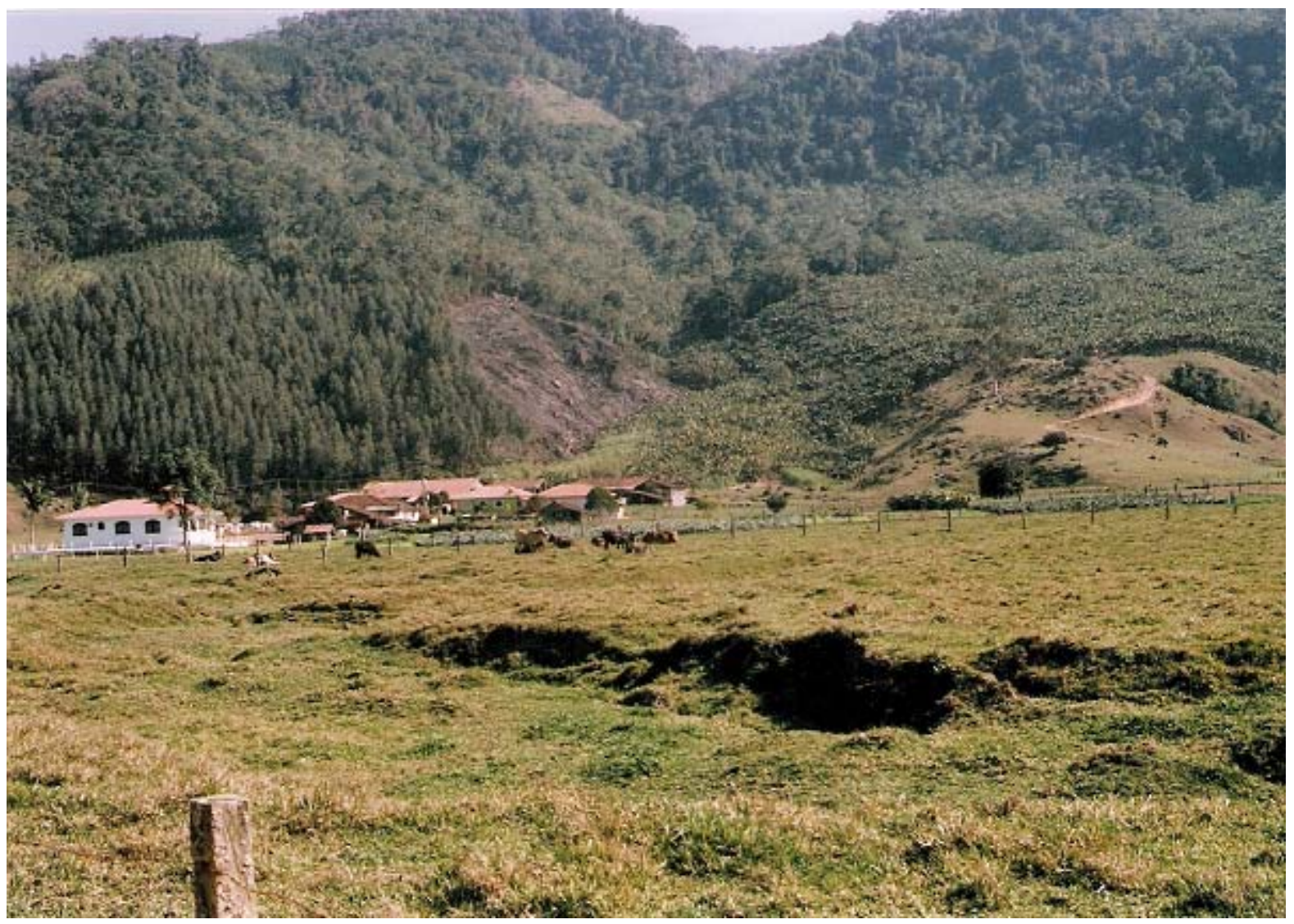

Figura 16 - Aspecto do vale do Rio Biguaçu, com pastagens na planície e o cultivo de banana, eucaliptos e vegetação secundária na encosta do morro, município de Antônio Carlos-SC. (Foto: Vicente R. Silva, julho/2006.).

No Planalto de Biguaçu/Três Riachos, através das formas de relevo de morros e serras, ocorre o escoamento superficial difuso, que promove o carreamento dos sedimentos mais finos. A perda de horizontes superficiais do solo nas encostas, exibem com frequência blocos e matacões graníticos. Geralmente, em uma parte dessas áreas o uso da terra é destinado a pastagens de gado bovino. O pisoteio do gado gera a formação de terracetes nas encostas, podendo evoluir para feições erosivas do tipo sulcos, ravinas e/ou nichos erosivos (Rosa, 1995, p.15). 
Tabela 17 - Unidades dos sistemas ambientais da bacia do rio Biguaçu-SC

\begin{tabular}{|c|c|c|c|c|}
\hline $\begin{array}{l}\text { Morfoestrutura } \\
\qquad\left(1^{\circ} \text { táxon }\right)\end{array}$ & $\begin{array}{l}\text { Morfoescultura } \\
\qquad\left(2^{\circ} \text { táxon }\right)\end{array}$ & $\begin{array}{c}\text { Tipo e formas de } \\
\text { relevo } \\
\text { ( } 3^{\circ} \text { táxon) }\end{array}$ & Litologia & Solos \\
\hline $\begin{array}{l}\text { 1-estrutura intrusivas } \\
\text { graníticas }\end{array}$ & $\begin{array}{c}\text { 1.1Planalto de } \\
\text { Cimeira-Serra das } \\
\text { Congonhas e Macaco } \\
\text { Branco }\end{array}$ & $\begin{array}{l}\text { 1.1.1Morros de topos } \\
\text { convexos com grande } \\
\text { densidade de drenagem }\end{array}$ & Granito & $\begin{array}{c}\text { Cambissolos e } \\
\text { Argissolos vermelho- } \\
\text { amarelos }\end{array}$ \\
\hline & $\begin{array}{l}\text { 1.2Planalto Costeiro - } \\
\text { Serra de São Miguel }\end{array}$ & $\begin{array}{l}\text { 1.2.1Morros de topos } \\
\text { alongados }\end{array}$ & Granito & $\begin{array}{c}\text { Argissolos vermelho- } \\
\text { amarelos }\end{array}$ \\
\hline $\begin{array}{l}\text { 2-Estruturas } \\
\text { metamórficas }\end{array}$ & $\begin{array}{c}\text { 2.1Planalto de } \\
\text { Biguaçu/Três Riachos }\end{array}$ & 2.1.1 Morros e colinas & $\begin{array}{c}\text { Rochas graníticas } \\
\text { gnaisses }\end{array}$ & $\begin{array}{c}\text { Cambissolos e } \\
\text { Argissolos vermelho- } \\
\text { amarelos }\end{array}$ \\
\hline $\begin{array}{l}\text { 3-Estruturas } \\
\text { sedimentares }\end{array}$ & $\begin{array}{c}\text { 3.1Planícies } \\
\text { fluviais } \\
\text { 3.2Planície } \\
\text { Costeira/Marinha }\end{array}$ & $\begin{array}{c}\text { 3.1.1 Planície Fluvial } \\
\text { do Rio Biguaçu } \\
\text { 3.1.2Planície marinha e } \\
\text { manguezal }\end{array}$ & $\begin{array}{l}\text { Areia, argilas, } \\
\text { cascalhos }\end{array}$ & $\begin{array}{c}\text { Cambissolos e } \\
\text { Gleissolos háplicos e } \\
\text { Gleissolos melânicos }\end{array}$ \\
\hline
\end{tabular}

\section{1-Planalto de Cimeira - Serras das Congonhas e Macaco Branco}

Morros de topos convexos nivelados em torno de 800 metros, com vales estreitos e medianamente profundos. Elevada densidade de canais de drenagem, com declividade predominante entre 3\% e 30\%. Dimensões interfluviais, variando entre 250 metros a 500 metros e entalhamento fluvial médio mais ou menos de 50 metros. Declividade predominante acima de $17^{\circ}$ ou $30 \%$. Altitudes médias dos topos variando de 800 metros a 885 metros. Rochas dominantes, granito Congonhas. Solos dominantes, Argissolos vermelho-amarelos e Cambissolos flúvicos. 


\section{2-Planalto Costeiro - Serra de São Miguel}

Morros de topos alongados e paralelos entre si. Topos aguçados e vale tipo V, bem marcados e profundos. Densidade de drenagem elevada, com entalhamento fluvial médio, ocilando entre 100 metros e 200 metros. Dimensões interfluviais acima de 700 metros. Declividades predominantes acima de $17^{\circ}$ ou 30\%. A altitude média dos topos é de 300 metros. As rochas dominantes, granito São Miguel. Os solos dominantes são o Argissolos vermelho-amarelos.

\section{1-Planalto de Biguaçu/Três Riachos}

Planalto com grandes morros de topos convexos, vertentes longas e vales profundos. Dimensões interfluviais ocilando entre 1.200 metros e 1.500 metros, com entalhamento médio dos vales acima de 270 metros. Declividades predominantes acima de 30\%. A altitude média dos topos varia entre 200 metros a 500 metros. As rochas dominantes são os gnaisses, quartizitos. Os solos dominantes são o Cambissolos flúvicos.

\section{1-Planície Fluviais}

A planície dos rios Biguaçu, Três Riachos, Farias e Rachadel, é ampla com áreas restritas de terraços fluviais e rampas coluvionares articuladas. Os materiais são constituídos de areia, cascalhos e lentes de argilas. As altitudes são de até 20 metros. A declividade varia de $2 \%$ a $5 \%$. Os solos dominantes são os Gleissolos e o Neossolos flúvicos. 


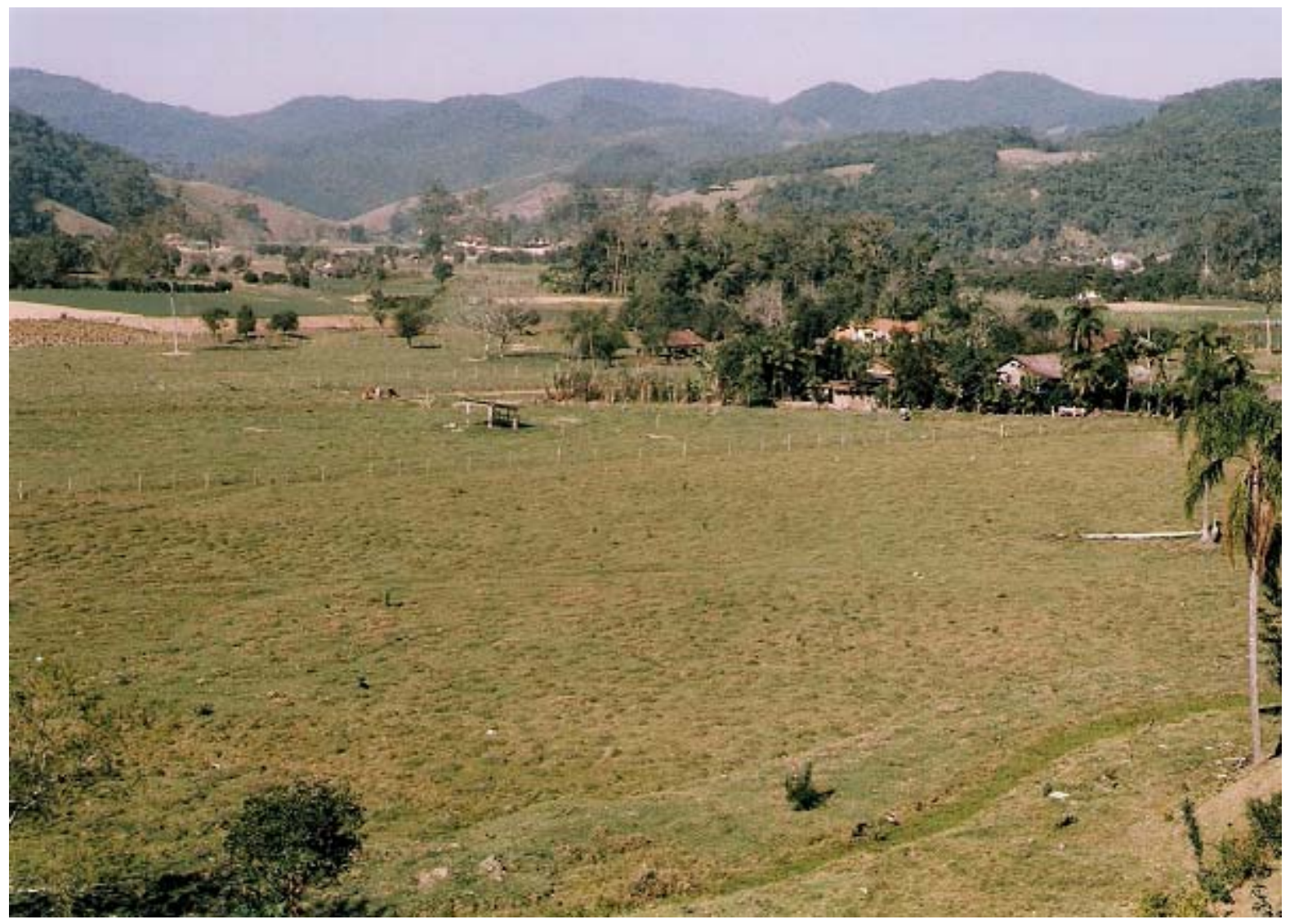

Figura 17 - Área de pastagens e hortaliças no baixo vale do Rio Farias no município de Antônio Carlos - SC. (Foto: Vicente R. Silva, julho/2006).

\section{2-Planície costeira/marinha}

Cordões arenosos de sedimentação marinha articuladas com planície de mangues. Praias atuais, terraços mainhos pleistocênicos e holocênicos e depósitos paludais. As declividades são inferiores a 2\%. As altitudes são abaixo de 10 metros. Os solos dominantes são os Neossolos quartzarênicos e os solos indiscriminados de mangues.

\subsubsection{1-Mapa hipsométrico}

A classe com altitudes inferiores a 100 metros está concentrada na porção sudeste da bacia. Além disso, temos os vales dos rios Biguaçu, Três Riachos, Saudade e da Guiomar com baixas altitudes, inclusive na faixa de 0 a 20 metros. Essas áreas com baixa altitude de até 20 metros, corresponde no mapa clinográfico, às declividades de 0 a 3\%. Já no mapa de unidades do relevo é representada pela planície fluvial. É na porção oeste da bacia, onde concentram-se 
as maiores altitudes, oscilando entre 200 metros até 880 metros. Toda essa região faz parte do Planalto de Cimeira e parte do Planalto de Biguaçu / Três Riachos.

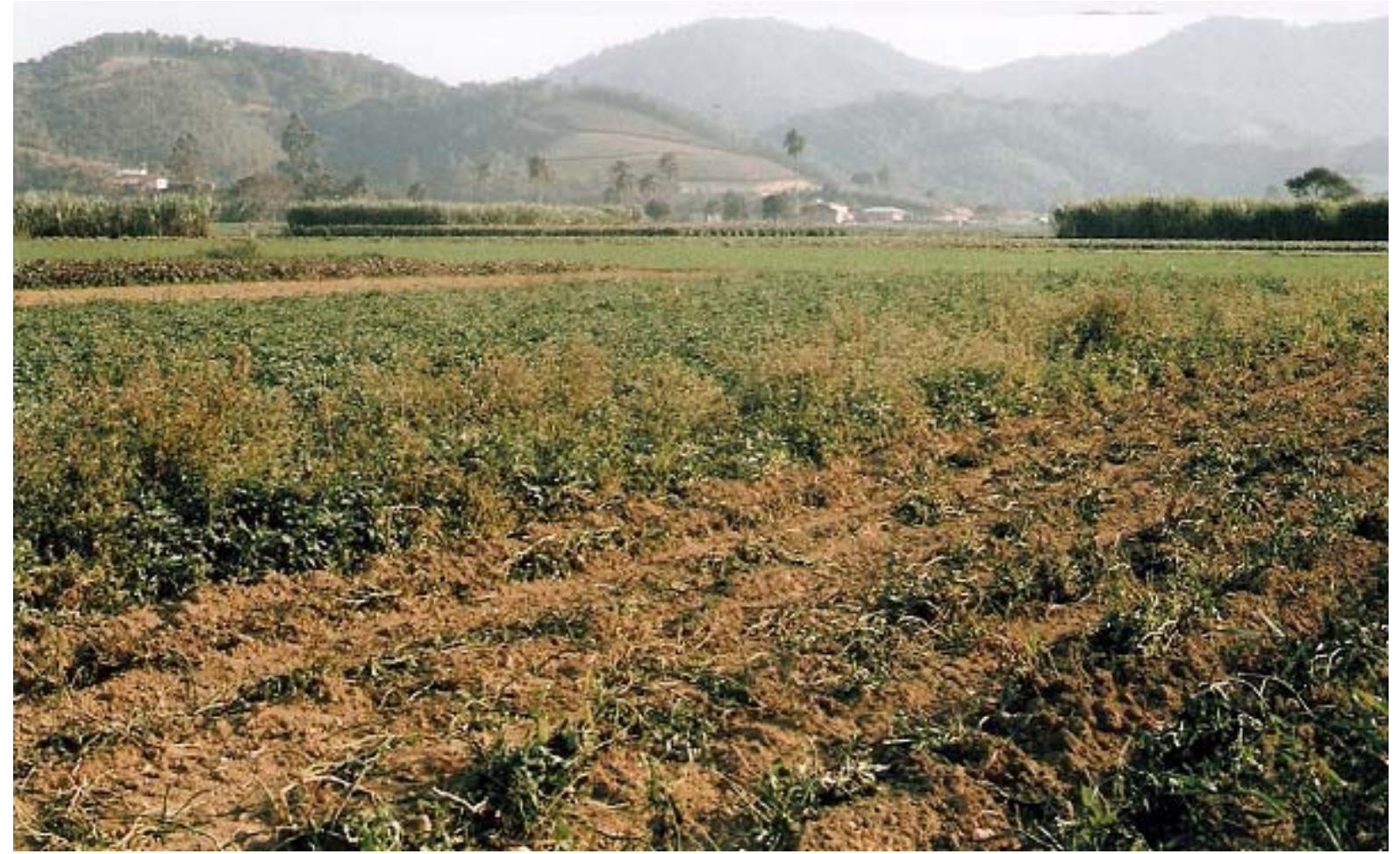

Figura 18 - Aspectos da planície do rio de Guiomar, com cultivo de hortaliças na localidade de Guiomar de Fora, município de Antônio Carlos-SC. ( Foto: Vicente R. Silva, julho/2006.)

Em geral, as maiores altitudes estão localizadas em áreas de rochas graníticas, pertencentes a Suíte Intrusiva Valsungana. Localmente, são representados pela Serra das Congonhas, Serra do Major e Serra do Macaco Branco. Já na unidade geológica Complexo Metamórfico-Migmático, localizadas no extremo sudoeste, com áreas com altitudes acima de 400 metros. Localmente, essa região é conhecida como Serra do Pai João e um trecho da Serra de Santa Filomena. 


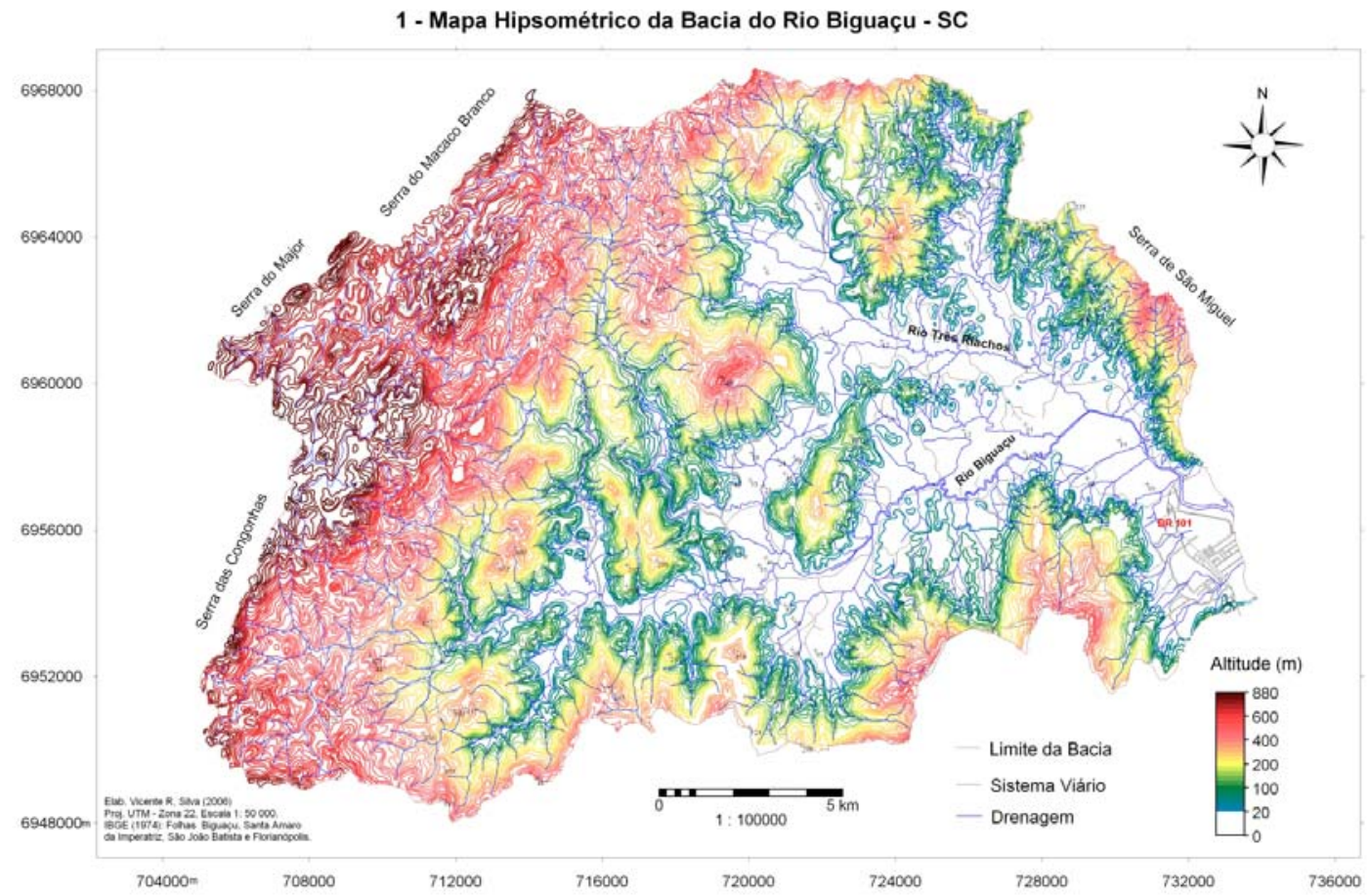

Figura 19 - Mapa Hipsométrico da Bacia do Rio Biguaçu-SC 


\subsubsection{2-Mapa Clinográfico}

O modelado de acumulação é formado por áreas com declividades inferiores a 6\%, que representa cerca de $24 \%$ da superfície total da bacia. As declividades inferiores a 6\% estão concentradas nas planícies fluviais dos rios: Biguaçu, da Guiomar, Farias, Rachadel, Saudade e Três Riachos.Também temos o rio do Louro e o ribeirão Vermelho (margem direita). O rio principal da bacia, o Biguaçu possui vastas áreas com baixa declividade, desde parte do alto e médio curso, a montante da cidade de Antônio Carlos até a foz na baía norte na cidade de Biguaçu.

A planície marinha também apresenta baixa declividade (inferior a 2\%), localizada a leste na zona urbana de Biguaçu, na área da planície sedimentar de Biguaçu. Na Unidade Geomorfológica Planalto de Cimeira (Suíte Intrusiva Valsungana), a oeste da bacia, possui áreas menores, embaciadas em altitudes de 700 a 800 metros, porém com declividades variando na faixa de $0-3 \%$; $3-6 \%$ e $6-12 \%$.

Na margem direita do rio Biguaçu, na localidade Alemanha, existe uma grande área drenada por um tributário do rio Biguaçu, com baixa declividade, no município de Biguaçu, identificada em trabalhos de campo.

Na unidade geológica Complexo Metamórfico-Migmático, as altitudes variam de 100 a 600 metros de altitudes, que corresponde ao Planalto de Biguaçu/ Três Riachos. As declividades variam entre $12 \%$ - $20 \%$; $20 \%$ - 30\% e > $30 \%$. Os solos dominantes são do tipo Cambissolos. Na porção nordeste da bacia estão presentes os solos Argissolos Vermelho-Amarelos. 


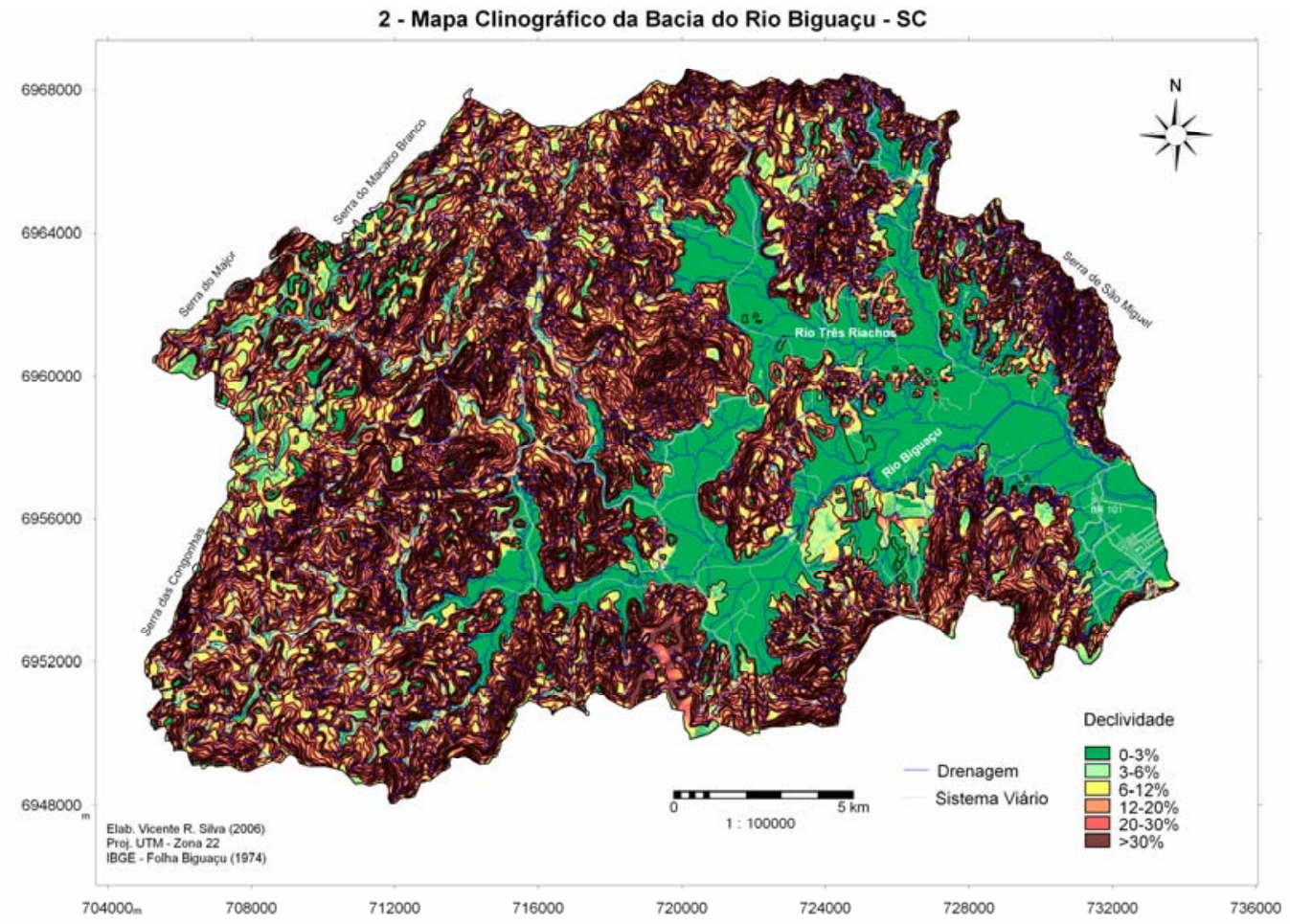

Figura 20 - Mapa Clinográfico da Bacia do Rio Biguaçu-SC. 


\subsubsection{3-Mapa de Unidades do Relevo}

Ocorre nítida compartimentação do relevo, onde as áreas de terrenos cristalinos de maior altitude correspondem aos terrenos cristalinos, representados por planaltos e serras. Os depósitos quaternários são formados pelas áreas de relevo plano, da planície fluvial e planície marinha.

O Planalto de Cimeira localizado na porção oeste da bacia constitui a região menos dissecada, com altitudes variando de 543 metros a 885 metros. Esse planalto está inserido dentro do município de Antônio Carlos. Os terrenos cristalinos de ampla distribuição na bacia representam o modelado de dissecação do tipo serra, com vertentes alongadas e fortes amplitude de relevo, podendo ser superior a 25\% de declividade. Os rios de maiores extensões da bacia têm suas nascentes no Planalto de Cimeira. Os terrenos cristalinos ocorrem em 76\% da área de estudo (modelado de dissecação). Já as áreas do modelado de acumulação, com baixa declividade são 24\% do total da bacia.

A maior unidade geomorfológica delimitada no mapa, é o Planalto de Biguaçu/Três Riachos (II). Sua ampla distribuição espacial só é interrompida pelo Planalto de Cimeira, a oeste e pela Serra de São Miguel e Planície Marinha a leste. Essa unidade tem contato com a planície fluvial, na parte central e leste da bacia.

O planalto de Biguaçu/Três Riachos tem na sua base o Complexo MetamórficoMigmático, formado por rochas graníticas, sendo as elevações mais dissecadas a Serra de Santa Filomena (ao sul), a Serra da Guiomar e a Serra de São Miguel. As altitudes são mais modestas na Serra de São Miguel, variando de 200 a 300 metros. No entanto, os migmatitos são rochas mais resistentes e portanto, menos dissecadas do Planalto de Biguaçu/Três Riachos, que integram as Serras do Pai João e parte da Serra de Santa Filomena, a sudoeste da bacia. As altitudes variam de 400 a 600 metros.

A Serra de São Miguel está situada na porção leste da bacia do rio Biguaçu, formada pelas rochas da Suíte Intrusiva Pedras Grandes (pEsp). Essa serra possui terrenos bem dissecados e rebaixados, com declividades superiores a 25\%. É nessa unidade do relevo onde localiza-se a pedreira de brita da Empresa Sulcatarinense. Essa região é o lugar de expansão de ocupação de moradias da cidade de Biguaçu. Em alguns setores da encosta pode tornar-se 
de riscos ambientais, devido principalmente à declividade acentuada e presença de espessos mantos de alteração.

A planície fluvial é constituída pelos rios: Três Riachos, Saudade, Biguaçu, Rachadel e Louro. São áreas planas com declividade ao redor de 2\%, sujeitas a riscos de inundação em eventos excepcionais de chuvas.

A planície marinha corresponde a área de $6,48 \mathrm{~km}^{2}$. É uma região susceptível a risco de inundação do rio Biguaçu e Caveiras, conjugados de eventos de maré alta. O uso do solo urbano que predomina é residencial. No mapa geológico pertencente ao quaternário marinho $(\mathrm{Qm})$, junto à baía norte. Trata-se de uma área de sedimentação transicional, formada pela praia de João Rosa e por 38 cristais praiais. A planície sedimentar de Biguaçu tem altitude de cerca de 2,24 metros (Fortes, 1996, p.69). 


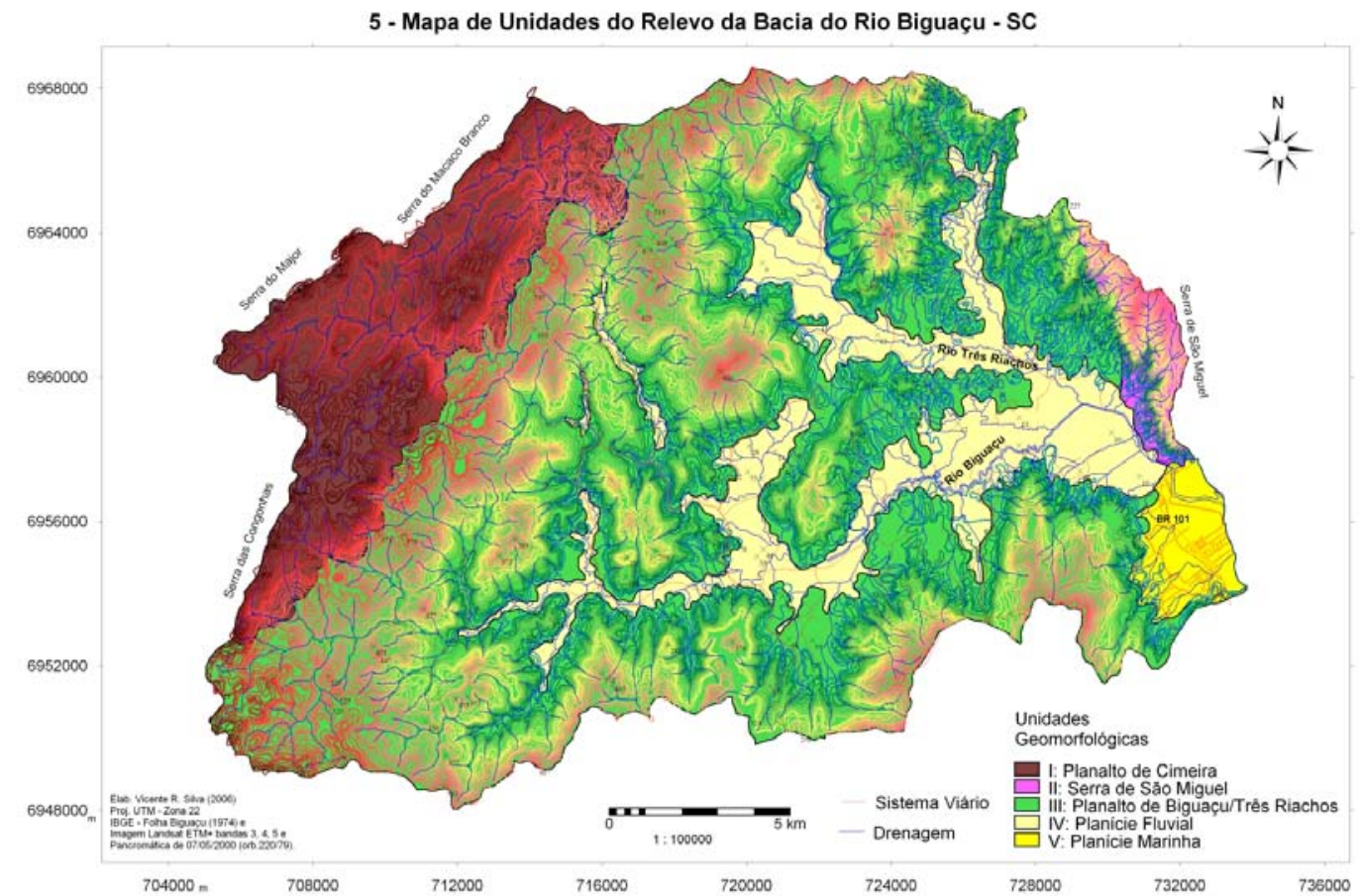

Figura 21 - Mapa de Unidades do relevo da Bacia do Rio Biguaçu-SC. 


\subsection{3-Características climáticas}

\section{Aspectos climáticos}

O clima da região Sul do Brasil possui uma característica geral marcante, que é a sua homogeneidade: nos aspectos da pluviometria e o ritmo estacional de seu regime. No Sul do Brasil há o domínio exclusivo do clima mesotérmico do tipo temperado, no que se refere a sua umidade. A homogeneidade e a unidade climática dessa região se deve a uma certa semelhança de unidade de fatores e processos genéticos, que interagem na formação do tempo. Dentre os fatores estáticos, destaca-se a posição e o relevo (Nimer, 1990, p.151).

A posição geográfica da região Sul na faixa de latitudes médias e a presença a leste do oceano atlântico, dão contribuição marcante no condicionamento climático regional. A região está delimitada na extremidade setentrional, pelo Trópico de Capricórnio, que passa na altura da cidade de Maringá, no Paraná e nos limites meridionais no paralelo $34^{\circ}$ Sul, no Rio Grande do Sul. Portanto, a quase totalidade de seu território situa-se no interior da zona temperada do sul, sem se adentrar muito paro o sul e nem se afastar muito da orla marítima.

“A posição latitudinal e marítima da região Sul propicia intensa insolação e evaporação, além de forte concentração de núcleos de condensação. Assim, ocorre a contribuição no acréscimo de chuvas em seu território, sempre que esta região é atingida por frentes frias e outros importantes fenômenos de ascendência dinâmica do ar” (Nimer, 1990, p.152).

O relevo da Região Sul é muito simples, tendo em vista, os traços através dos quais ele age sobre os processos climáticos, (...) (op.cit.). O mesmo autor, acrescenta quanto aos fatores dinâmicos do clima dessa região, que a sua compreensão, depende do mecanismo atmosférico. Deve-se mencionar também, os demais fatores do clima, como o relevo, a latitude, a continentalidade ou maritimidade (correntes marítimas), que atuam nos processos climáticos em interação com os sistemas regionais de circulação atmosféricas.

Para Freyesleben (1979) apud Fortes (1996, p.43), o clima da região costeira catarinense é controlado por dois principais sistemas atmosféricos, ou seja, a Massa Tropical Atlântica (mTa) e a Massa Polar Atlântica (mPa). Segundo a primeira autora (op.cit.), a “mTa” atua durante todo o ano, com destaque na primavera e no verão, já em relação a “mTa”, essa atua com mais freqüência durante o outono e inverno. A atuação da "mTa”, 
permite dias com boas condições de tempo, com pouca nebulosidade e ventos fracos. Não ocorrem grandes variações de temperatura diárias, oscilando entre $22^{\circ} \mathrm{C}$ a $30^{\circ} \mathrm{C}$ (Monteiro; Furtado, 1995, p.125).

Atua também, a Frente Polar Atlântica que resulta do contato da mPa com a "mTa”, que provoca chuvas na região. A Massa Polar Atlântica (mPa) é uma massa de ar frio, originária da Antártica, que se desloca, geralmente, para o norte. Sua trajetória é basicamente marítima no verão e continental no inverno. A massa Tropical Atlântica é uma massa de ar quente, com deslocamento marítimo, que é abastecida pela própria evaporação da água do mar. Sua atuação é de posição semi-permanente entre as latitudes $18^{\circ}$ e $35^{\circ}$ Sul (Orselli, 1986, p.38-39).

Freyesleben (1979) apud Fortes (1996), descreve o avanço da (mTa) que tem como centro de origem o anticiclone semifixo e permanente do Atlântico Sul, é reconhecido pelos ventos norte, nordeste e noroeste. Esses ventos provocam a elevação da temperatura. No entanto, a Massa Polar Atlântica, que se origina nas altas latitudes do hemisfério sul, provoca tempo estável com baixas temperaturas. Podemos identificar essa massa de ar pela presença dos ventos de quadrantes sul e sudeste, que atuam com mais freqüência no outono e inverno.

\section{Principais Aspectos Pluviométricos}

A região Sul do Brasil apresenta, de forma geral, grande uniformidade na distribuição espacial das chuvas. Em função disso, na quase totalidade de seu território a média de precipitação anual varia de 1250 mm a 2000 mm, não configurando nenhum lugar da região com carência de chuvas (Nimer, 1990, p.157). De acordo com o autor (op.cit.), a relativa uniformidade do regime de chuvas, não é só em relação aos índices totais de chuvas, mas também, na forma pela qual, as chuvas se distribuem durante o ano.

Na condição de possuir clima temperado, com uma boa distribuição de chuvas ao longo do ano, se torna muito difícil, prever o trimestre do ano, em que as máximas ou as mínimas irão se concentrar. Tudo vai depender, da atuação dada pelas correntes pertubadoras de Sul. É na faixa litorânea de Santa Catarina, onde o regime anual de precipitação apresenta ritmo estacional, com tendência mais regular. É nessa faixa estreita do Estado, onde o máximo pluviométrico pertence ao verão e seu trimestre mais chuvoso, ocorre nos meses de 
janeiro, fevereiro e março. Já os índices mais baixos insidem na maioria das vezes, no inverno e secundariamente no outono. Trata-se, portanto de um ritmo estacional típico das regiões de clima tropical (Nimer, 1990, p.159).

\section{Principais Aspectos Térmicos}

Na Região Sul brasileira, a temperatura (apesar de sua diversidade espacial), exerce um papel semelhante ao da pluviosidade, ou seja, “o papel de unificadora e uniformizadora do clima regional” (Nimer, 1990, p.163). Apesar, dessa região situam-se na zona subtropical, “o inverno, na maior parte do território é acentuado”. De fato, de maio a agosto, a temperatura média se mantém, relativamente baixa em todo o território. É nesse período que a região sente os efeitos típicos do inverno das regiões de clima temperado, com a chega de frentes polares, causadoras de chuvas, sucedidas por massa polar. Com efeito, ocorre forte queda nas temperaturas (...).

No entanto, o inverno climático da região Sul possui, em média, a duração de quatro meses, em Santa Catarina e no Rio Grande do Sul. Em geral, os meses de junho e julho são os mais sensíveis, quanto a sensação de frio. E o autor acrescenta “(...) a distribuição geográfica da temperatura durante o inverno é determinada pela maior ou menor influência marítima, pela variação da latitude e sobretudo, pela desigualdade do relevo”.

Nessa região, a variação de altitude do relevo tem papel de destaque no verão. Já no inverno, é importante a variação da latitude e a maritimidade (Nimer, 1990, p.171). Em relação ao comportamento térmico, podemos ter três domínios climáticos: o de clima subquente, o de clima mesotérmico brando e o de clima mesotérmico médio.

\section{Clima Subquente}

"Nos territórios submetidos a esse tipo de clima, nenhum mês apresenta temperatura média inferior a $15^{\circ}$ C”. Corresponde em Santa Catarina a estreita faixa litorânea, limitada pelas curvas altimétricas de 400m até o nível do mar. Em termos percentuais, representa apenas 1,4\% da superficie do Estado. É nessa região, onde o verão apresenta-se com grande frequência de temperaturas elevadas, com médias em janeiro entre $26^{\circ} \mathrm{C}$ e $24^{\circ} \mathrm{C}$. O inverno é ameno, possuindo temperatura média do mês mais frio, superior a $15^{\circ} \mathrm{C}$. É nessa área, onde apresenta-se a temperatura média anual mais elevada da região Sul do Brasil, sendo superior a $20^{\circ} \mathrm{C}$ (Nimer, 1990, p.182). 
Percebe-se que, na faixa litorânea as diferenças das condições térmicas entre o verão e inverno, são menos significativas, em virtude da ação moderada da forte influência do mar, do que, comparada ao oeste no interior dos estados sulistas. Em suma, o inverno ameno resulta um clima subquente na região Sul, sendo considerado um clima de transição entre o clima tropical das latitudes baixas do Brasil e o clima temperado mesotérmico das latitudes médias da região Sul. O clima subquente é considerado um prolongamento climático da região sudeste na região Sul (Nimer, 1990, p.182-184).

A área da bacia do rio Biguaçu, no litoral central de Santa Catarina encontra-se sob influência do clima subquente. Na região Sul, os sistemas atmosféricos regionais que influenciam o seu clima pode ter grandes flutuações anuais. Isso pode acarretar, a ocorrência de notáveis desvios pluviométricos anuais, tanto no verão como no inverno, dando condições de variabilidade de condições climáticas muito distintas, com destaque na pluviometria e umidade (Nimer, 1990, p.187).

\section{O clima da bacia do Rio Biguaçu (clima local)}

A região conurbada de Florianópolis, situada no paralelo $27^{\circ}$ Sul, não possui características climáticas marcadamente temperadas. Apresenta tipos climáticos controlados pela penetração, atuação e choque das massas Polar Marítima e Tropical Marítima do Atlântico, tendo verões quentes e invernos amenos, típicos dos climas subtropicais (Mendonça, 2004, p.2). Para Monteiro (1963) apud Mendonça (2004, p.6), essa região do litoral central de Santa Catarina, apresenta mesotermia e precipitações bem distribuídas ao longo do ano, sem contudo, ter uma estação seca definida. Para o primeiro autor (op.cit.), o regime térmico não tem marcante sucessão nas quatros estações do ano. Na realidade, ocorrem dois períodos quentes (entre $18^{\circ} \mathrm{C}$ e $22^{\circ} \mathrm{C}$ ), um mais quente (acima de $22^{\circ} \mathrm{C}$ ) e um mais fresco (entre $15^{\circ} \mathrm{C}$ e $18^{\circ} \mathrm{C}$ ).

A bacia do rio Biguaçu que integra todo o território do município de Antônio Carlos e grande parte do município de Biguaçu, está sob a área de influência da Estação Climatológica Principal de São José que pertence ao Instituto Nacional de Meteorologia (Inemet) do Ministério da Agricultura. As coordenadas geográficas da estação são: 27 35’ de latitude Sul e 48 $34^{\circ}$ ' de longitude Oeste de Greenwich. A altitude da estação é de 2,00 metros, situada no bairro Praia Comprida, em São José-SC. Situa-se a cerca de 14 km da cidade de Biguaçu. Os 
dados de clima disponíveis, foram processados pela Epagri (Empresa de Pesquisa Agropecuária e Extensão Rural de Santa Catarina).

Mediante análise de dados fornecidos pela Epagri (Estação Principal de São José) e dados da Estação Climatológica de Antônio Carlos (atualmente desativada), verificam-se totais pluviométricos elevados na região e ausência de estação seca definida. A média do total anual de precipitação para o período de 1991 a 2005 foi de 1.775,46 mm. Na Estação de Antônio Carlos (período de 1977 a 1986), foi de 2.208,10 mm. A precipitação média mensal demonstra valores mais elevados em Antônio Carlos, com 184,00 mm e em São José com $148,95 \mathrm{~mm}$.

O município de São José possui clima temperado, do tipo subquente. A temperatura média varia de $18^{\circ} \mathrm{C}$ e $15^{\circ} \mathrm{C}$ no inverno e $26^{\circ} \mathrm{C}$ e $24^{\circ} \mathrm{C}$ no verão. A temperatura média anual é superior a $20^{\circ} \mathrm{C}$. Em geral, as chuvas são bem distribuídas, sem apresentar um mês seco, conforme demonstram os valores da tabela 18. Os totais pluviométricos mais elevados correspondem aos meses na estação verão e primavera, embora ocasionalmente, possam ocorrer no outono e inverno (Herrmann; Mendonça; Campos, 1993, p.50).

Em Biguaçu, a atuação dos ventos está sujeita a desvios provocados pela orientação geral do relevo. Esses fatos podem ser percebidos pelas direções e frequências dominantes dos ventos de quadrantes norte e sul, com percentuais de frequência de 31,68\% e 30,83\% respectivamente. A tabela 18 abaixo mostra a distribuição da direção do vento e freqüência.

Tabela 18 - Direção dos ventos e freqüência.

\begin{tabular}{|c|c|}
\hline Direção do ventos & Freqüência (\%) \\
\hline Norte $(\mathrm{N})$ & 31,68 \\
\hline Sul (S) & 30,83 \\
\hline Nordeste (NE) & 16,11 \\
\hline Sudeste (SE) & 11,38 \\
\hline Noroeste (NW) & 1,40 \\
\hline Sudoeste (SW) & 1,11 \\
\hline Oeste $(\mathrm{O})$ & 0,55 \\
\hline Calmaria & 1,94 \\
\hline Abstenções & 5,00 \\
\hline Total & 100,00 \\
\hline
\end{tabular}

Fonte: Epagri 


\section{Análise da Pluviometria}

O regime pluviométrico tem como característica típica de área de litorânea de Santa Catarina, a ausência de uma estação seca definida, com chuvas distribuídas durante todo o ano. A estação do ano que apresenta o maior índice de precipitação é o verão, com média anual de 227,26 mm em Biguaçu e 255,00 em Antônio Carlos (tabela 19). A distribuição da média anual de precipitação na bacia do rio Biguaçu, demonstra uma certa regularidade, apesar de ocorrer redução dos totais nos meses de junho $(80,83 \mathrm{~mm})$, julho $(91,82 \mathrm{~mm})$ e agosto (79,66 mm), segundo dados da Estação de São José (1991-2005). Porém, podem ocorrer chuvas torrencias em qualquer mês, inclusive no período de inverno, onde em agosto de 1919, houve 513,00 mm. Também em 1983, no mês de julho, com totais de 513,00, conforme a tabela 20 .

Tabela 19 - Precipitação média (mm), por estação do ano em Biguaçu e Antônio Carlos-SC.

\begin{tabular}{|l|c|c|}
\hline \multirow{2}{*}{ Município / Estação } & Biguaçu (SC) & Antônio Carlos (SC) \\
\cline { 2 - 3 } & (Est. Climat. S. José) & (DNAEE) \\
\cline { 2 - 3 } & $\mathbf{1 9 9 1 - 2 0 0 5}$ & $\mathbf{1 9 7 7 - 1 9 8 6}$ \\
\hline Verão (D-J-F) & 227,26 & 255,00 \\
\hline Outono (M-A-M) & 130,65 & 161,33 \\
\hline Inverno (J-J-A) & 83,42 & 130,40 \\
\hline Primavera (S-O-N) & 154,37 & 188,80 \\
\hline MÉDIA & 148,92 & 184,00 \\
\hline
\end{tabular}

Fonte: Epagri e DNAEE.

Tabela 20- Precipitação média mensal (mm) em Biguaçu e Antônio Carlos-SC

\begin{tabular}{|l|c|c|c|}
\hline Município & Biguaçu (1991-2005) & Biguaçu (1977-1986) & $\begin{array}{c}\text { Antônio Carlos (1977- } \\
\text { 1986) }\end{array}$ \\
\hline Meses & (Est. Climat. S. José-SC) & (Est. Climat. S. José-SC) & (DNAEE) \\
\hline Janeiro & 262,36 & 177,69 & 230,80 \\
\hline Fevereiro & 225,50 & 207,31 & 281,30 \\
\hline Março & 161,47 & 218,37 & 216,60 \\
\hline Abril & 109,97 & 88,12 & 128,10 \\
\hline Maio & 120,54 & 93,98 & 139,30 \\
\hline Junho & 80,83 & 65,37 & 98,20 \\
\hline Julho & 91,82 & 113,46 & 167,40 \\
\hline Agosto & 79,66 & 109,20 & 127,10 \\
\hline Setembro & 141,80 & 124,94 & 146,40 \\
\hline Outubro & 169,37 & 153,10 & 212,60 \\
\hline Novembro & 152,38 & 160,52 & 207,40 \\
\hline Dezembro & 192,59 & 174,34 & 252,90 \\
\hline TOTAL & 1788,29 & 1686,4 & 2208,1 \\
\hline
\end{tabular}

Fonte: Epagri e DNAEE 
Visando realizar uma comparação, foi composta uma tabela com dados de precipitação de Biguaçu, obtidos na Estação Climatológica de São José e na Estação Climatológica de Antônio Carlos, ambas no período de 1977 a 1986. Foram acrescentados os dados de precipitação média mensal de Biguaçu, abrangendo o período de 1991 a 2005 (tabela 20). Conforme demonstram os dados, ocorre um aumento da precipitação em direção ao alto vale do rio Biguaçu. Ao comparar os dados das duas estações climatológicas, no período de 1977 a 1986, constata-se que apenas a média do mês de março em Biguaçu é superior a de Antônio Carlos, apesar de apresentar índices muito próximos.

Uma das possíveis causas do maior índice de precipitação para o interior da bacia, deve-se a própria conformação do vale, onde a precipitação mais elevada ocorre nas áreas da unidade do relevo Planalto de Cimeira (Serra do Leste Catarinense), nas serras de Congonhas, do Macaco Branco e do Major, no interior do município de Antônio Carlos. Predominam nessas áreas as chuvas do tipo orográficas, onde a Massa Tropical Atlântica (mTa) é dominante no verão e é instabilizada pelo aquecimento continental associado aos efeitos orográficos, dando origem a precipitações do tipo 'pancadas de chuvas', que se caracterizam pelo grande volume de chuvas, concentrado em curto espaço de tempo (Monteiro, 1992, p.26).

A tabela 21, mostra os anos e os meses de maior precipitação, representada pela Estação Climatológica de São José. As chuvas que ocorreram em julho de 1983, provocaram as maiores enchentes da história de Santa Catarina, principalmente no vale do rio Itajaí-Açu. Nos anos de 1919 (agosto) e 1983 (julho), a precipitação atingiu 513 mm. Também, ocorreram inundações nos anos de 1991 (novembro), com 549,70 mm e em 1995 (dezembro), com totais de 563,20 mm. No interior do município de Antônio Carlos, na localidade de Santa Bárbara, ocorreu no dia 11 de março de 1994, um deslizamento de terra que soterrou parte de uma casa, matando três crianças de uma mesma família (Herrmann; Mendonça; Campos, 1993, p.51). 
Tabela 21 - Período de maior índice pluviométrico registrado em Biguaçu-SC (Estação Climatológica de São José-SC)

\begin{tabular}{|c|c|c|c|}
\hline ANO & total do ano (mm) & Mês & total do mês \\
\hline 1919 & 2305,00 & agosto & 513,00 \\
\hline 1957 & 2089,00 & novembro & 451,30 \\
\hline 1983 & 2598,00 & julho & 513,00 \\
\hline 1991 & 1725,90 & novembro & 549,70 \\
\hline 1994 & 1870,80 & fevereiro & 432,70 \\
\hline 1995 & 2024,20 & dezembro & 563,20 \\
\hline 1997 & 2170,90 & janeiro & 625,00 \\
\hline 2001 & 2360,70 & fevereiro & 537,00 \\
\hline
\end{tabular}

Fonte: Epagri

Pela análise da tabela 21, o ano de 1983 foi o mais chuvoso, com totais anuais de 2.598,00 mm, no entanto, não é o ano com maior volume de precipitação em 24 horas (tabela 22). Entre 1926 a 2005, as precipitações máximas em 24 horas, registram cerca de 20 anos, com precipitação acima de 140 mm. Podemos destacar, os seguintes valores: 1928 (março); 1936 (abril); 1973 (julho); 1991 (novembro); 1998 (janeiro); 2001 (fevereiro); 2004 (janeiro) e 2005 (setembro) (tabela 22).

Tabela 22 - Precipitação máxima em 24 horas (mm) no período de 1926-2005, na Estação São José-SC.

\begin{tabular}{|c|c|c|}
\hline Ano & Máxima absoluta (mm) & Mês \\
\hline 1926 & 192,00 & fevereiro \\
\hline 1928 & 236,40 & março \\
\hline 1936 & 207,90 & abril \\
\hline 1957 & 206,10 & abril \\
\hline 1973 & 241,90 & julho \\
\hline 1978 & 187,10 & março \\
\hline 1979 & 190,30 & fevereiro \\
\hline 1983 & 144,00 & dezembro \\
\hline 1986 & 160,00 & outubro \\
\hline 1991 & 404,80 & novembro \\
\hline 1994 & 227,40 & fevereiro \\
\hline 1995 & 206,60 & dezembro \\
\hline 1998 & 305,60 & janeiro \\
\hline 1999 & 260,90 & janeiro \\
\hline 2000 & 264,50 & janeiro \\
\hline 2001 & 536,50 & fevereiro \\
\hline 2002 & 229,90 & janeiro \\
\hline 2003 & 255,90 & dezembro \\
\hline 2004 & 375,30 & janeiro \\
\hline 2005 & 307,10 & setembro \\
\hline
\end{tabular}

Fonte: Epagri 
A tabela 23 apresenta os anos entre 1934 e 1996, com 170 dias de chuvas ou mais, no período analisado de 1911 a 2005. Desses dados selecionados, de um total de 15 anos, cerca de 4 anos (30,76\%), possuem 6 meses de chuvas ou mais. Os anos com maior número de dias de chuva, correspondem aos de 1938 e 1983, em ambos o total de chuva foi de 135 dias.

Tabela 23 - Número de dias de chuva ocorrido em um ano em Biguaçu-SC.

\begin{tabular}{|l|l|l|l|l|l|l|l|l|l|l|l|l|l|l|l|}
\hline Ano & 1934 & 1936 & 1937 & 1938 & 1939 & 1943 & 1957 & 1966 & 1970 & 1979 & 1983 & 1984 & 1990 & 1993 & 1996 \\
\hline $\begin{array}{l}\text { Dias } \\
\text { de } \\
\text { Chuva }\end{array}$ & 171 & 173 & 170 & 195 & 183 & 172 & 182 & 176 & 179 & 172 & 195 & 171 & 179 & 173 & 183 \\
\hline
\end{tabular}

Fonte - Epagri

\subsection{4-Aspectos hidrográficos e hidrológicos}

Na região sul do Brasil, a maioria dos rios exerceu um papel de destaque na conquista e ocupação do território, através da colonização e instalação de núcleos de povoamento. Podese considerar que, a drenagem como um "produto do relevo”, condicionada aos aspectos ‘determinantes’ litotectônicos. Essa afirmativa é mais aplicável às bacias hidrográficas mais recentes, que drenam a vertente atlântica. Assim, grande parte dos aspectos morfológicos atuais é o reflexo do arranjo e da evolução da drenagem durante o Cenozóico, sobre um substrato geológico, na qual, os rios, em parte, se adaptaram (Justus, 1990, p.190).

As variações no nível do mar foram comuns no quaternário. Ocorreram longos períodos de transgressões e regressões marinhas, associadas às mudanças climáticas. Essas flutuações climáticas tiveram grande influência na atuação dos processos morfogenéticos fluviais, no interior e no litoral. A vazão foi um dos componentes das correntes de águas, que sofreram alterações na sua potência e implicações no padrão de fluxo dos canais (op. cit.).

A bacia hidrográfica é produto de um equilíbrio dinâmico, pois é resultante da interação de diversos fatores intervenientes (físicos e biológicos), presentes e passados, onde as águas correntes constituem o principal agente de interação. A presença de uma ou mais feições marcantes não significa, o predomínio de determinado fator interveniente (litologia, tectônica, relevo etc), mas tão somente o resultado do equilíbrio dinãmico dos componentes interatuantes nesse sistema (Justus, 1990, p.200). 
Mudanças climáticas e tectônicas são eventos presentes no decorrer do tempo geológico. Tais eventos somados às alterações humanas imprimem na paisagem, uma dinâmica, a hidrografia. Com efeito, verifica-se essa dinâmica pela presença de formas herdadas e pelo caráter de instabilidade na maioria dos rios da região sul brasileira. As feições estruturais condiciona o encaixamento da drenagem em áreas de diversidade litológica, que ocorre nas regiões de rochas ígneas e metamórficas pré-cambrianas da unidade de relevo da Serra do Leste Catarinense (unidade de relevo Planalto de Cimeira).

Na classificação adotada pelo IBGE, a bacia do rio Biguaçu, em Santa Catarina, pertence a Bacia hidrográfica de Sudeste. O regime fluviométrico dos rios litorâneos é o tropical, que abrange vasta região, desde a divisa com o estado de São Paulo até as proximidades da Ilha de Santa Catarina Parlé (1978) apud Justus (1990, p.207). Em geral, os rios dessa região apresentam perfis longitudinais com declives acentuados e a presença no seu curso superior de leitos acidentados, vales suspensos e cascatas tipo “véu de noiva”.

O rio Biguaçu nasce na serra das Congonhas a 778 metros de altitude e deságua na Baía orte, defronte à Ilha de Santa Catarina. As sedes municipais de Biguaçu e Antônio Carlos localizam-se próximas à margem direita do referido rio; Biguaçu situa-se no baixo curso, próximo à foz, e Antônio Carlos no médio curso. O rio Farias é o maior tributário da bacia do rio Biguaçu. Nasce na serra do Major, a cerca de 853 metros de altitude. Na serra de Congonhas, a oeste da bacia, nasce também o tributário, rio Rancho Miguel (margem esquerda) (Reitz, 1988, p.399). Na Serra do Pai João nasce o rio Rocinha.

Os divisores de águas que limitam a área, estão representados ao norte pelas elevações conhecidas como serras de São Miguel, que separa a bacia do rio Biguaçu das bacias dos rios Camarão e Inferninho, e Macaco Branco que separa as bacias dos rios Inferninho e Tijucas; a oeste, as serras do Major e das Congonhas constituem os interflúvios das bacias hidrográficas dos rio Biguaçu e Tijucas; e ao sul, as serras do Pai João e Santa Filomena constituem o limite da bacia do presente estudo com a bacia hidrográfica do rio Maruim. A Serra da Guiomar constitui o interflúvio das sub-bacias do rio Três Riachos e do rio Rachadel, afluentes do rio Biguaçu. A área da bacia do rio Rachadel é de 59,9 km2, segundo Neis (1997, p.8). Junto a foz do Biguaçu, na Baía Norte, localiza-se a praia do Tamanco ou de João Rosa. 


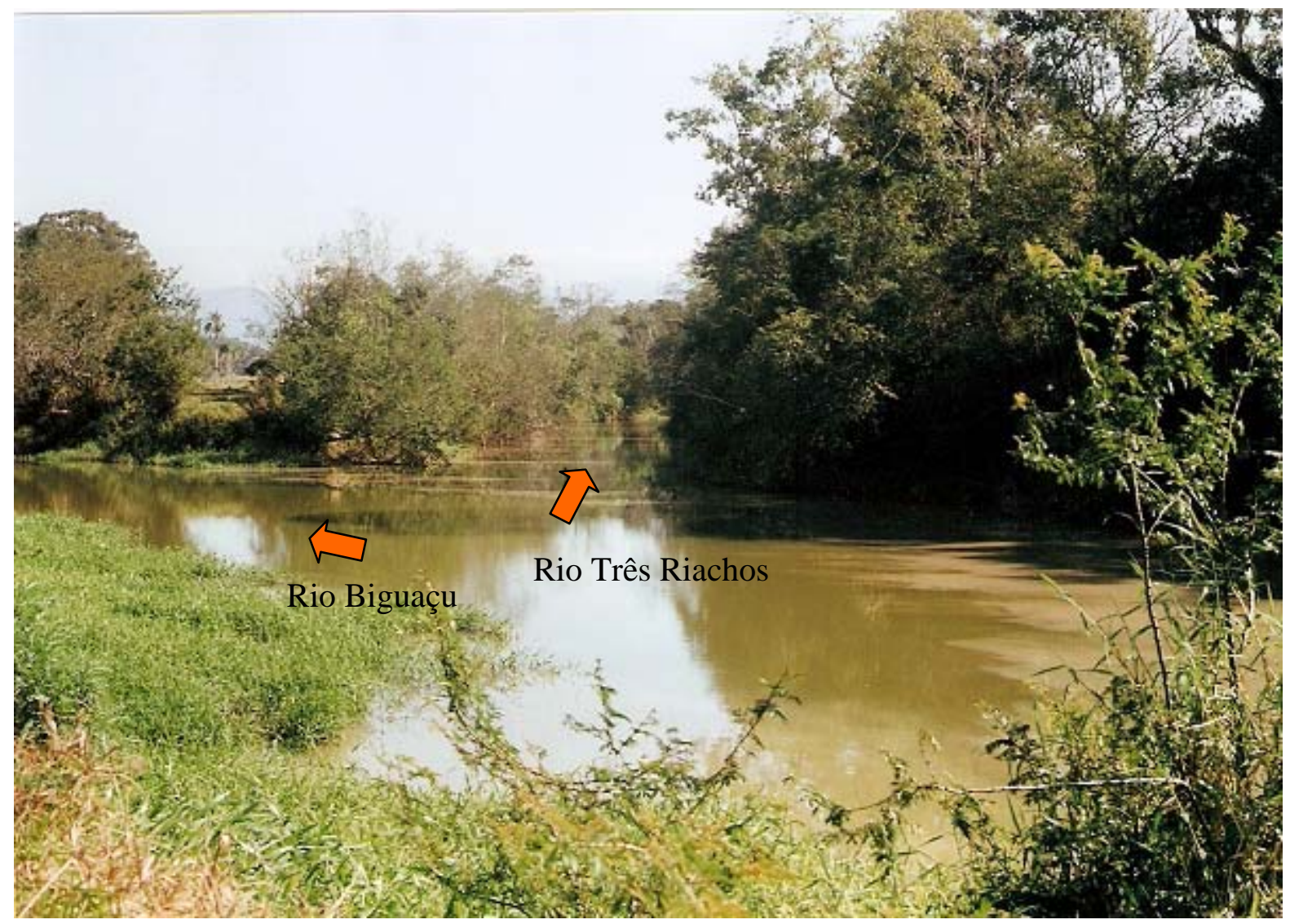

Figura 22: Foz do Rio Três Riachos (margem esquerda) no Rio Biguaçu no município de Biguaçu-SC. ( Foto: Vicente R. Silva, julho/2006.)

Para efeitos de gerenciamento dos recursos hídricos do estado de Santa Catarina, a bacia do rio Biguaçu, pertence a RH-8 litoral centro. Segundo os dados, a bacia do rio Biguaçu possui área de $382 \mathrm{~km}^{2}$, com densidade de drenagem de 1,52 km/ km² e uma vazão mínima de 2,3 (m³/s) (Santa Catarina, 1997, p.26).

No quadro da RH-8 litoral centro, as principais atividades poluidoras de água, se referem à concentração urbano-industrial e ao plantio intensivo de hortaliças. No aspecto da qualidade dos recursos hídricos, as principais fontes poluidoras são: a) esgoto domiciliar especialmente no rio Biguaçu; b) resíduos sólidos/lixo, presente em todas as bacias da região; c) agrotóxicos, devido ao cultivo intensivo de hortaliças, onde os resíduos são levados para o rio Biguaçu; d) poluição industrial que ocorre no rio Biguaçu; e) degradação do solo, sendo mais intenso o processo de degradação dos solos no rio Biguaçu. Na qualidade de água, o rio Biguaçu é classificado como classe 2 Santa Catarina, (1986) apud Santa Catarina, (1997, p.84). 
Nesse estudo (op.cit.), também se faz referência que, nas áreas planas da bacia do rio Biguaçu, a ausência de vegetação e ocupação irregular, em áreas de planície de inundação, favorece a ocorrência periódica de enchentes. As modificações do homem na dinâmica natural do rio, através do desmatamento, edificações, pavimentação, detritos urbanos etc., acarretam uma diminuição do tempo de retenção das águas da chuva , dificultando a capacidade de escoamento superficial dos rios (Santa Catarina, 1997, p.90). Segundo esse estudo, o rio Biguaçu possui cerca de $40 \mathrm{~km}$ de extensão. Os maiores tributários seriam o rio Rachadel com 24 km de extensão o rio Três Riachos com 15 km de extensão e o rio Farias com 21 km de extensão (Santa Catarina, 1997, p.133).

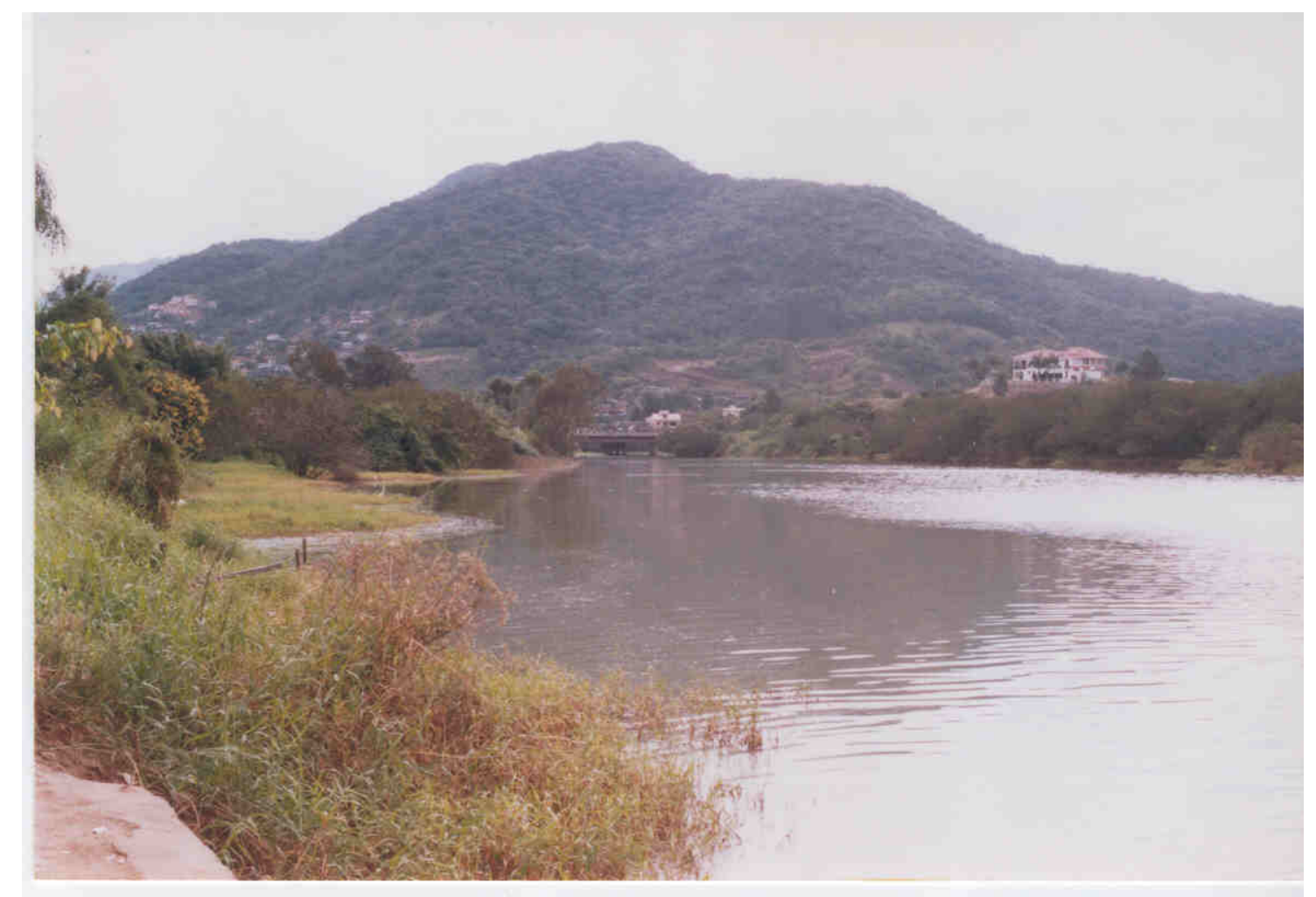

Figura 23 - Baixo curso do rio Biguaçu, na zona urbana de Biguaçu-SC. Ao fundo ponte da BR-101 e Serra de São Miguel. (Foto Ivanete Nardi, maio/2003).

Na pesquisa de Ricardo Veado (1999), que utilizou a metodologia sistêmica aplicada no zoneamento geográfico sistêmico para o estado de Santa Catarina, fez-se um diagnóstico atual do funcionamento dos geossistemas a nível estadual. Nesse estudo, a bacia do rio Biguaçu faz parte do “Geossistema Planície Costeira Quaternária,” formada pela paisagem “Geofácies Planície Central”; “ Geossistema Serras do Leste Catarinense,” e a paisagem 
“Geofácies Mar de Morros” (Veado, 1999, p.104). O pesquisador também faz referência às enchentes. Ele destaca a combinação de fatores climáticos, com mau uso da terra, tornando um problema de difícil solução. E acrescenta: “A desproteção das vertentes está na base do problema, pois é a área fonte de sedimentos que são carreados pelos rios pelo escoamento superficial, facilitado pela falta de vegetação” (Veado, 1999, p.124).

Padrão de drenagem

São arranjos espaciais dos cursos fluviais, que podem ser influenciados por atividades morfogenética, pelo tipo de rochas, controle estrutural do terreno, pela diferença de declividades e pela evolução geomorfológica da região (Christofoletti, 1980, p.103). O tipo mais comum, na área de estudo, é a drenagem sub-dendrítica e paralela, com presença de vertentes com declividades acentuadas do embasamento cristalino. Podem também, existir controles estruturais que motivem a ocorrência de espaçamento regular, quase paralelos, das correntes fluviais.

Na planície fluvial, os leitos são quase planos, onde o canal divaga na planície, formando meandros sobre uma ampla faixa de deposição fluvial (Justus, 1990, p.208). Essa descrição se assemelha às condições encontradas em nossa área de pesquisa. No baixo vale do rio Biguaçu, a planície é plana e com baixa declividade, até a foz na baía norte, defronte a Ilha de Santa Catarina.

Abastecimento público de água na cidade de Antônio Carlos

A primeira estação de tratamento de água funciona no município há cerca de 30 anos. Essa estação encontra-se na localidade de Canudos. A vazão é de 1,00 litro por segundo, que equivale ao consumo de 100 casas (80 economias). A segunda estação de tratamento de água foi inaugurada em 1992, no rio Farias. O sistema tem duas caixas de areia e cascalho com 30 metros de areia de piscina e filtro lento de desinfecção. A área das duas caixas é de 152 m². São retirados cerca de 7,00 litros por segundo, abastecendo 1.100 economias.

A atual rede de água em Antônio Carlos possui 48 km de extensão. Há previsão da expansão da captação de água do rio Farias, com a construção de uma nova adutora e nova estação de tratamento de água (ETA), passando a vazão para 50,00 litros por segundo. O local da captação está na cota de 110 metros. O levantamento topográfico já foi realizado no local, 
segundo informações do Sr. Anselmo Manes, responsável pelo escritório local da Casan (inf. verbal, julho de 2006).

Dos seis parques aquáticos do município, a melhor água é a do Parque Aquático Recanto do Sol, na localidade Canto dos Guesser, pois utiliza água captada em uma cachoeira do rio Farias, segundo Anselmo Manes (inf. verbal, julho/06). Na maior indústria do município a Vonpar (refrigerantes e cerveja), a água é captada em uma nascente (cachoeira), situada atrás da unidade.

A Casan em Antônio Carlos já atende à localidade de Santa Catarina, no município de Biguaçu e deve atender a novos loteamentos na localidade. Em Antônio Carlos não há rede coletora de esgotos e tratamento de esgotos. De acordo com dados da Confederação Nacional de Municípios (ano de referência 2000), Antônio Carlos, possui 511 (29,40\%) domicílios ligados a rede geral canalizada e cerca de 918 (52,82\%) domicílios com poços ou nascentes (na propriedade) (CNM, 2006).

Com relação à infra-estrutura de esgotamento sanitário, a rede geral de esgoto ou pluvial atende a 65 domicílios (5,48\%); fossa séptica, com 819 domicílios (69,06\%); fossa rudimentar, com (6,07\%) e vala, com 552 domicílios; rio, com 209 domicílios (17,62\%). Esses dados do ano de referência 2000. Em relação ao destino do lixo no município de Antônio Carlos, a coleta por serviço de limpeza atende a 1.406 domicílios (80,90\%); queimado com 295 domicílios (16,97\%), segundo dados do ano referência 2000.

\section{Abastecimento público de água na cidade de Biguaçu}

O fornecimento de água tratada em Biguaçu é realizado pela empresa Casan, que abrange $\quad 77 \%$ do total dos domicílios existentes, sendo que deste total $85 \%$, refere-se à área urbana e 8\% à área rural. Uma parte da população rural utiliza água proveniente de fontes, porém não há controle quanto a potabilidade (Santa Catarina, 2005c, p.7).

A água fornecida pela estatal do governo de Santa Catarina provém do rio Pilões e do rio Cubatão, localizados no município de Santo Amaro da Imperatriz (região do aglomerado de Florianópolis), percorrendo cerca de $40 \mathrm{~km}$. Em Biguaçu há 12.000 ligações, que abastecem o distrito-sede de Biguaçu e as localidades de Saudades e Três Riachos. Essas informações foram obtidas no escritório local da Casan, em Biguaçu, com o Sr. Edemir Muller Coelho (inf. verbal, março 2007). 
Problemas da dinâmica das águas ligadas à ação humana

As inserções humanas promoveram alterações na dinâmica dos ecossistemas, com mudanças significativas no comportamento dos rios e baías. Nos ambientes naturais, é normal o processo de formação de solos, lixiviação, erosão, deslizamentos, modificações do regime hidrológico e de cobertura vegetal, mesmo sem a interferência humana. Porém, quando o homem desmata para fazer agricultura, constrói, transforma o ambiente, acaba rompendo um equilíbrio dinâmico, potencializando os processos naturais, provocando consequências negativas para a sociedade (Cunha; Guerra, 1996, p.344).

A nível local, constatou-se, em trabalhos de campo, o assoreamento do rio Biguaçu e de outros tributários, a retificação de trechos de rios da referida bacia e o uso da terra com pastagens e agricultura até as margens dos rios.

No alto e médio curso do rio Biguaçu, em geral, as águas são transparentes. No entanto, durante trabalho de campo, em julho de 2005, a montante da cidade de Antônio Carlos após uma chuva de pequena intensidade, constatou-se que a água do rio tornou-se barrenta, mostrando a intensidade do processo erosivo, com perda de solo, bastante rápida pelo escoamento superficial.

A problemática da retificação de canais fluviais

As obras de retificação em canais fluviais alteraram a dinâmica natural dos rios. A falta de estudo prévio de todos as componentes que atuam na bacia, antes das obras, provocou impactos não previstos nos projetos de engenharia. Essas obras visavam atenuar ou mesmo sanar problemas relacionados às enchentes, com histórico de longas datas, nos municípios de Antônio Carlos e Biguaçu.

Através de obras de engenharia foi realizada a canalização, em trechos do sistema fluvial. Tais intervenções modificaram a calha dos rios, acarretando impactos na planície de inundação. Dentre os diversos processos de canalização, podemos destacar a retificação de canais. O objetivo dessas obras era o controle das cheias, a drenagem de terras alagadas e a melhoria do canal para a navegação (Cunha, 1998, p.242-243).

A utilização desse tipo de obra de engenharia gera polêmica, sendo considerada técnica imprópria, pois acarreta danos ao ambiente Keller (1981) apud Cunha (1998, p.243). 
A autora, descreve os impactos geomorfológicos derivados da retificação de canais, a saber: mudança do padrão de drenagem, pois há redução no comprimento do canal; a perda de meandros; aprofundamento e alargamento do canal; diminui a rugosidade do leito e aumenta seu gradiente.

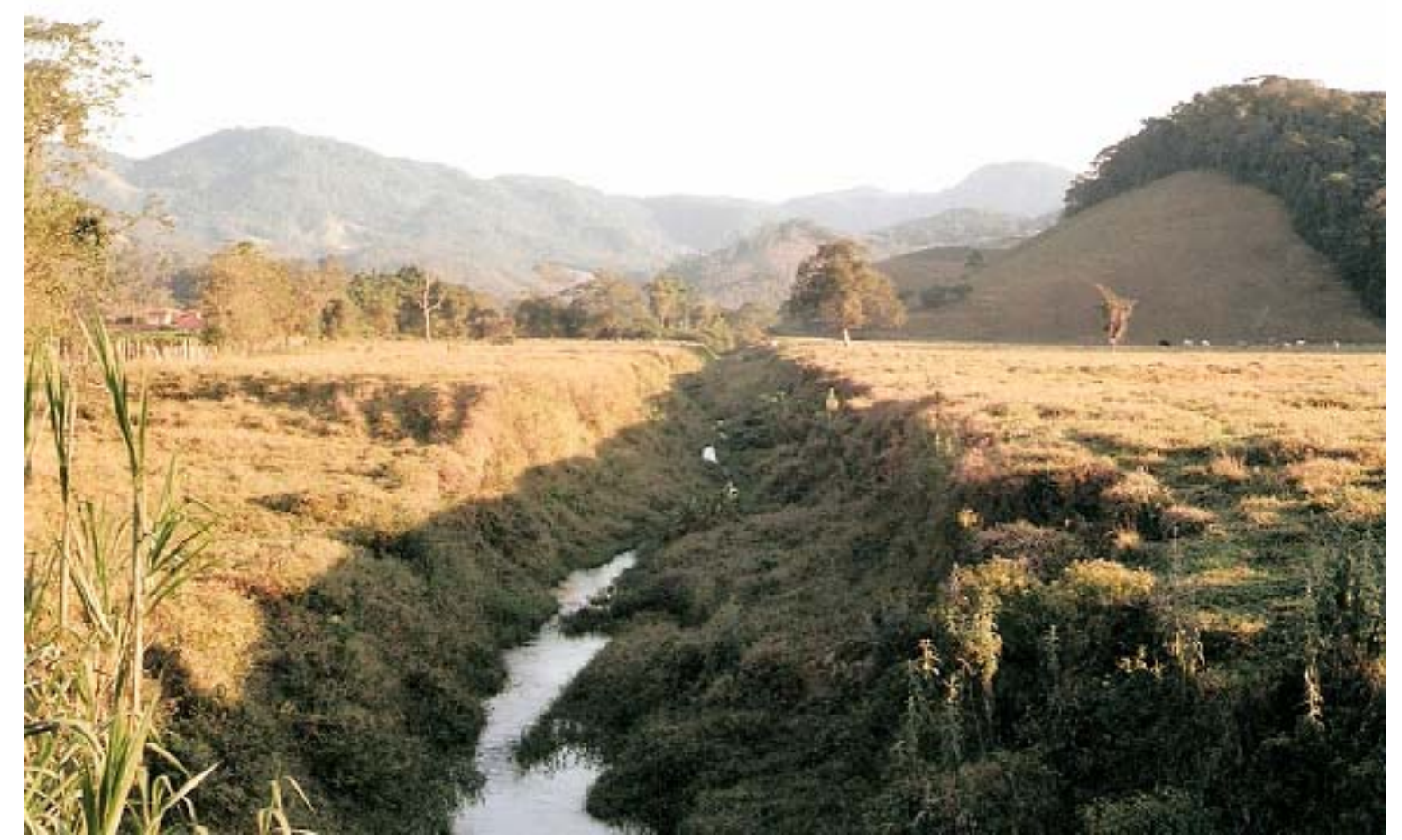

Figura 24 - Canal retificado do Rio do Louro, próximo a estrada que dá acesso à localidade de Santa Maria no município de Antônio Carlos - SC. (Foto: Vicente R. Silva, julho/2006).

Com efeitos, os rios, em geral, tendem a elaborar formas de deposição na sua foz. De modo geral, percebe-se que as implicações advindas da mudança de traçado e retificação de canais, não são consideradas. Para a população ribeirinha, o interesse imediato é o combate a inundações que ocorrem na região.

Justus (1990, p.214), que analisou a questão, afirma que os processos morfodinâmicos relacionados ao escoamento fluvial abrangem aos modelados de acumulação fluvial e as margens dos rios diretamente atingidos pela inundação. A implantação de serviços de infraestrutura como água, luz e vias de circulação se torna onerosa e problemática. Ocorre a insalubridade da área, decorrente do nível de água no subsolo elevado, agravado pelo advento de enchentes com perdas materiais e humanas. 


\section{A retificação do Rio Biguaçu e tributários}

A bacia do rio Biguaçu pertence a vertente atlântica do litoral central de Santa Catarina. De acordo como Mapa de Unidade do Relevo, foi delimitada a Unidade Planalto de Cimeira (Serra do Leste Catarinense), localmente representado pelas Serras de Congonhas, do Major e do Macaco Branco, no limite oeste da bacia do rio Biguaçu, dentro do município de Antônio Carlos.

A drenagem é perene, tendo em vista os altos e regulares índices pluviométricos, segundo a Estação Climatológica Principal de São José. A bacia do rio Biguaçu tem aproximadamente $27 \mathrm{~km}$ de comprimento e uma largura média de $18 \mathrm{~km}$, com drenagem disposta de oeste para leste. No médio curso, o rio Biguaçu possui largura que varia de 18,60 metros até 42, 60 metros no seu leito maior (Fortes, 1996, p.40). Em nossa medição, obtemos, a montante da foz do rio Três Riachos (seção 1), a largura de 17,35 cm (trecho retificado do rio Biguaçu). Na seção 2, na cidade de Biguaçu, acerca de 200 metros da foz, a largura foi de 57,0 metros, em medidas realizadas em julho de 2005.

Visando combater as enchentes nas cidades de Antônio Carlos e Biguaçu, o rio Biguaçu foi retificado em vários trechos, numa extensão de 16 km, entre 1966 e 1970 (entre a cidade de Antônio Carlos e Biguaçu). Também foram retificados os seguintes tributários da bacia: rio Três Riachos, que teve 7,5 km do médio e baixo curso retificados. O rio Saudade foi retificado em 2,25 km do seu canal, no município de Biguaçu. Em Antônio Carlos foi retificado, o rio da Guiomar, na extensão de 3,0 km, no período de 1973 e 1977, próximo do distrito-sede de Antônio Carlos. O rio Rachadel teve obras de retificação em um trecho de 1,25 km em 1969. O ribeirão Vermelho (margem direita), foi retificado em aproximadamente $5,0 \mathrm{~km}$.

Na planície marinha de Biguaçu, o rio Caveiras, que integra a bacia do rio Biguaçu, com nascentes na Serra Santa Filomena, na porção sul da bacia, foi retificado cerca de 1,5 km de seu canal (Fortes, 1999, p.40). O fenômeno das inundações do rio Biguaçu expresso por bruscas alterações de sua vazão, sendo comuns nas áreas do médio e baixo vale, onde as comunidades rurais e urbanas vêm convivendo há décadas com esses eventos. Na cidade de Antônio Carlos as enchentes ocorreram nos anos de 1916, 1927, 1932, 1937, 1957 e 1972, de 
acordo com Kremer (1993, p.55). Também ocorreram grandes inundações nos anos de 1983 e 1991.

Outros autores, também questionam a realização de retificação de rios, no município de São José, que faz limite ao sul com Biguaçu. Nesse caso, o rio Maruim foi retificado e uma das consequências é maior rapidez no escoamento, tem alagado áreas onde antes não ocorria o problema. Segundo os autores "as retificações e dragagens dos rios mostram-se ineficazes por não considerarem a dinâmica integral do gradiente de drenagens e subestimarem o nível de vazão em chuvas excepcionais (...)” (Herrmann; Mendonça; Campos, 1993, p.70). As inundações em Santa Catarina que no passado eram fenômenos estritamente naturais, vêm assumindo cada vez mais características antrópicas (Lago, 1989, p.261).

Como fenômeno natural, a própria conformação da bacia do rio Biguaçu apresenta elevações ao oeste, sul e norte. As altitudes variam do nível do mar até +_ 900 metros, nas serras com alta declividade, bastante dissecadas pela inserções dos canais fluviais, em linhas estruturais e em espessos mantos de alteração. Essas características favorecem a concentração da água. Muitos rios catarinense apesar de percorrerem extensões reduzidas, apresentam amplitudes significativas entre os canais de cabeceiras e o nível do mar (Lago, 1988, p.57). Na planície fluvial, a baixa declividade (inferior a 2\%) e a sinuosidade dos canais provocam o retardamento do escoamento das águas, favorecendo as inundações (Fortes, 1999, p.41).

As obras de retificações realizados pelo extinto DNOS, obtiveram resultados satisfatórios, em relação ao regime das cheias. Porém, a referida obra resultou na obstrução da foz do rio Biguaçu, dificultando o lançamento das águas na baía norte. Os serviços de retificação no rio Biguaçu e tributários resultaram no aumento da velocidade do fluxo da corrente e no aumento da competência de transporte de sedimentos, gerando acelerado processo de assoreamento da foz do rio (Fortes, 1996, p.77).

Fortes (1999), constatou que a barra de desembocadura do rio Biguaçu, está formando-se há mais de 30 anos. O aumento considerável do crescimento das barras marginais do rio Biguaçu, foi após o início das obras de retificação do rio Biguaçu (1966) e a tomada de fotografias aéreas de 1978. O crescimento da barra indica estar associada à influência humana. Em medição, em campo, pelo autor (op. cit.), a barra tinha cerca de 1.000 
metros de comprimento e 700 metros de largura, mantendo a direção do seu eixo principal. A taxa de crescimento anual média da barra era de 23,43 metros (Fortes, 1999, p.42).

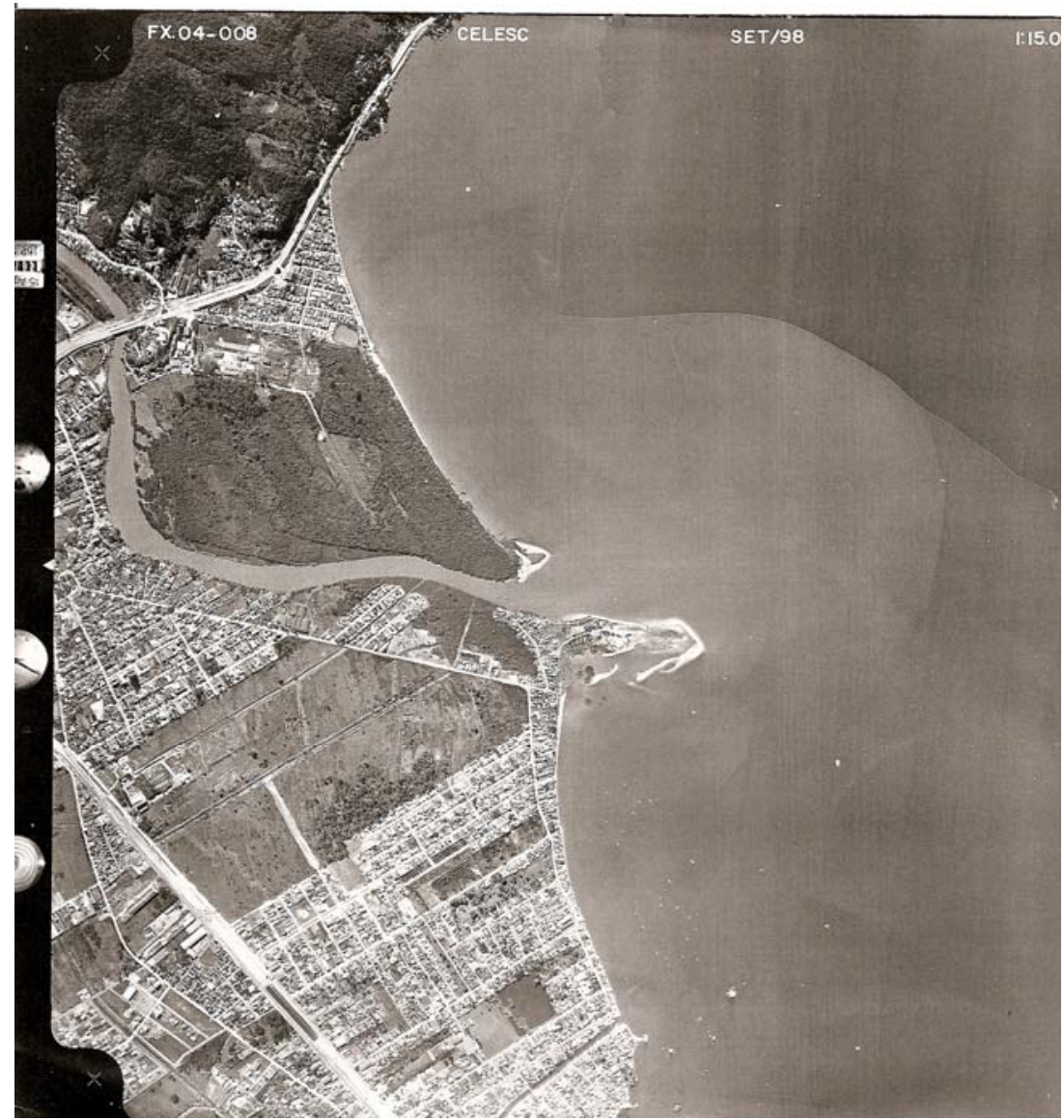

Figura 25 - Detalhe da desembocadura do rio Biguaçu no distrito-sede de Biguaçu-SC.

O canal retificado acaba provocando uma reação em cadeia, onde os tributários e o curso principal promovem a retomada erosiva do canal e, com isso, o aumento da carga sólida levada para o baixo vale. Em 1994, uma empresa de Florianópolis realizou a desobstrução da foz do rio Biguaçu. O projeto previa a retirada de um volume de $350.000 \mathrm{~m}^{2}$ de material, atingindo uma profundidade de 2,00 metros. O material dragado foi depositado na margem esquerda do rio Biguaçu. acerca de 300 metros da foz. O material foi depositado sobre o manguezal e paleocanais fluviais. Devido a sua localização, a baixa altitude, junto à margem esquerda, esse aterro, poderá tornar-se mais uma fonte de poluição. No rio Biguaçu foram executados serviços de dragagens em novembro de 1994 e março de 1996, indicando a necessidade de uma frequência bianual do serviço (Herrmann, 1999, p.245). 
O assoreamento acelerado da foz do rio Biguaçu se deve a falta de planejamento, que envolvesse outros componentes interatuantes na bacia hidrográfica, como, por exemplo, o processo erosivo nas encostas, os padrões de uso da terra, a ausência de mata ciliar em trechos significativos ao longo dos cursos d’água.

\section{A degradação ambiental do rio Biguaçu}

A intensa sedimentação dos canais de drenagem tem sérias consequências nas atividades humanas, pois diminui a profundidade dos leitos dos rios e baías, criando problemas à navegação e intensificando os efeitos das inundações. No final do século 19, até o início do século 20, o rio Biguaçu era utilizado largamente como via de transporte. Esse rio era navegável por pequenas embarcações (canoas e barcas rasas “chatas”), no trecho da foz até $22 \mathrm{~km}$ a montante, até a confluência com o rio Farias (foz).

Na bacia do rio Biguaçu, o rio do Louro (margem direita), no município de Antônio Carlos, nasce na Serra de Santa Filomena (ao sul), era navegável até a sua foz no rio Biguaçu (Reitz, 1988, p.204).

Vale destacar que a comunidade do Alto Biguaçu (atual município de Antônio Carlos) ficava isolada no período das chuvas, pois as estradas de terra, que a ligavam Biguaçu, ficavam intrasitáveis. A utilização da navegação fluvial era uma vocação natural, que foi explorada (usada). Com o aumento do povoamento do Alto Biguaçu, cada vez mais no começo do século 20, cresceu também, o comércio e o transporte fluvial. Já havia grandes excedentes de açúcar, café, feijão, farinha de milho, milho e cachaça, além de aves e animais vivos.

No final do século 19, o rio Biguaçu apresentava um razoável volume de água, porém com pouca profundidade. Nessas condições, eram usadas pequenas canoas e chatas. A primeira chata a navegar o rio Biguaçu pertenceu a João Henrique Muller, em 1895 (Reitz, 1988, p.256). O dono de uma serraria no Alto Biguaçu, Fernando Amadeu Wiese era proprietário da única balsa usada para o transporte de madeira serrada para a "Barra" (Biguaçu), na foz do rio Biguaçu.

Os barcos desciam o rio Biguaçu e na volta para o Alto Biguaçu, traziam fazenda (tecidos), linha, charque, fumo, sal, fósforo, querosene, pregos, cimento, cal etc. para as casas comerciais (vendas). As chatas que foram usadas no rio Biguaçu não dispunham de vela e 
leme. "Eram empurradas rio acima ou rio abaixo, com auxílio de varejões confecionados de bambu fino (Bambusa tuldoides)” (...) (Reitz, 1988, p.261).

De acordo com o autor citado, existiam no rio Biguaçu oito portos, citados a seguir, de montante para jusante: Porto de Leopoldo Freiberger, Porto de João Henrique Muller, Porto de Antônio Rita, Porto de Fernando Amadeu Wiese, Porto de Lourenço Medeiros Rios, Porto de Romão Schwarz, Porto de João Adão Reitz e Porto de Biguaçu.

A ocorrência de uma grande enchente, em 1916, provocou um enorme assoreamento do rio, interrompendo a navegação. O período de apogeu de transporte fluvial foi de 1895 a 1916 (Reitz, 1988, p.74-75). O término da navegação do rio Biguaçu é devido ao assoreamento da barra de desembocadura. Deve-se acrescentar ainda, a diminuição do volume de água, provocado pelo desmatamento dos colonos alemães na região serrana da localidade Alto Biguaçu (atual município de Antônio Carlos). O encerramento da navegação do referido rio tem conotação ecológica, pois foi o resultado de uma má política de colonização, durante o governo imperial (Reitz, 1988, p.76-77).

Fortes (1996, p.56-57), enumera os fatores que contribuem para a ocorrência de enchentes no vale do rio Biguaçu: a) a baixa altimetria da planície fluvial e marinha, inferior a 2,0 metros; b) lençol freático próximo à superfície e a alta permeabilidade de areias das cristas praiais; c) a localização do distrito-sede de Biguaçu. A impermeabilização do solo da cidade é cada vez maior, pelo crescimento acelerado da ocupação humana, que promove a diminuição da infiltração e o aumento do escoamento superficial, com maior descarga de água no rio; d) nos períodos de alta pluviosidade, associado à maré alta, que implica no barramento das águas do rio Caveiras e rio Biguaçu; e) a BR-101, que corta a cidade, no sentido norte-sul, formando uma barreira, com elevação 2,00 metros de altura sobre a planície marinha. A rodovia dificulta o livre escoamento das águas das chuvas; f) o rio Caveiras, apesar de sua pequena extensão e volume, tem contribuído com as enchentes na cidade, devido a dificuldade de vazão nos períodos de chuvas torrenciais; g) no baixo curso do rio Biguaçu, de regime estuarino, que leva à floculação de argilas, contribuindo para diminuir o canal do rio, associado a ação de marés altas, que se extende rio adentro.

O rio Caveiras é um rio altamente poluído por esgotos domésticos e lixo. A jusante da rodovia federal houve invasão de famílias de baixa renda e ocupação em áreas de preservação 
permanente, onde o manguezal foi destruído por desmatamentos e aterros ilegais. Atualmente, no local está instalada a comunidade da favela de Saveiro, com pouca infra-estrutura e moradias precárias. Trata-se de área de risco ambiental, sujeita à ocorrência de inundações. Não há rede coletora de esgotos e estação de tratamento de esgotos, os efluentes das residências são lançados diretamente no rio Caveiras.

Na cidade de Biguaçu o processo de favelização iniciou-se em 1987, quando o município passou a receber grandes contigentes de imigrantes, vindos de outras cidades do estado e de outros estados. Assim, a cidade "passou a atrair formas de ocupação a partir de loteamentos irregulares e clandestinos, sem legalização da terra e sem infraestrutura, transformados em verdadeiras favelas” (Souza, 1997, p.43).

Em análise sobre os impactos ambientais dos episódios pluviais na área conurbada de Florianópolis, no período de 1980 a 1995, Herrmann (1999, p.245) explica que não é necessário que ocorra índice de precipitação excepcional para promover enchentes e escorregamentos. A autora (op.cit.) esclarece que as áreas mais atingidas por enchentes e enxurradas localizam-se na região geomorfológica planície costeira. Nesses locais, os sedimentos quaternários modelam as planícies de inundação, localizadas no baixo curso do rio Biguaçu, onde as áreas planas, com altitudes ao redor de 5 metros, são frequentemente atingidas por enchentes.

Entre 1980 e 1995, foram registrados 11 enxurradas, 10 enchentes moderadas, 2 enchentes de calamidade pública e 2 deslizamentos. Os maiores problemas ocorrem quando a precipitação diária é superior a 100 mm, com grande probabilidade de haver inundação, em locais onde moram em torno de 20.000 habitantes (+ 75\% da população do município de Biguaçu (Oliveira; Herrmann, 2001, p.172-173).

Os autores (op.cit.), ainda destacam o papel da criação de novos espaços imobiliários, em encostas sujeitas a deslizamento e em áreas onde enchentes fazem parte da própria dinâmica natural do lugar. Com efeito, quando as águas transbordam os leitos fluviais, estas ocupam a planície de inundação. As catástrofes tendem a ocorre, pois a população que por falta de opção, acaba por construir moradias em locais inadequados do espaço físico, através da transformação imobiliária da natureza em habitat (Oliveira; Herrmann, 2001, p.175). 
De acordo com Herrmann: Mendonça; Campos (1993, p.51), ocorreu em Antônio Carlos, em março de 1994 um deslizamento de terra, que soterrou parte de uma casa, matando três pessoas da mesma família. Em trabalho de campo realizado por nós, em 08/07/06, foi constado, que o episódio ocorreu na localidade de Santa Bárbara na estrada Rio Farias. Segundo informação de moradora vizinha, a tragédia se deu na madrugada do dia 11/03/1994, pois a chuva já durava uma semana.

Segundo Justus (1990, p.212-213), na Serra do Leste Catarinense, ocorre a presença de modelados bastante dissecados, associados a espessos mantos de alteração, em vertentes de forte declividade. Os valores de precipitação, em geral, são mais elevados nas serras, localizadas a oeste da bacia do rio Biguaçu. Na baía norte e sul da Ilha de Santa Catarina, o processo de assoreamento é intenso, com destaque nas últimas décadas, com o aumento considerável da população urbana nos municípios de Florianópolis, São José, Biguaçu e Palhoça. A carência quase total da rede de esgoto e estação de tratamento de esgoto é comum nesses municípios, onde os efluentes domésticos são lançados diretamente nos rios e baías.

Nas áreas de maior declividade, em geral, os vales são bem fechados, em forma de "V". Verificou-se em trabalhos de campo, a presença de locais com cicatrizes de erosão, anfiteatros, mantos espessos de elúvios e terracetes formados pelo pisoteio de gado bovino (Silva; Ross, 2006, p.8). A atividade de pecuária semi-extensiva ocorre de forma generalizada em toda a bacia. Os pastos estão nas planícies fluviais e nas áreas de colinas e morros nos alto e médio vale dos tributários do rio Biguaçu. 


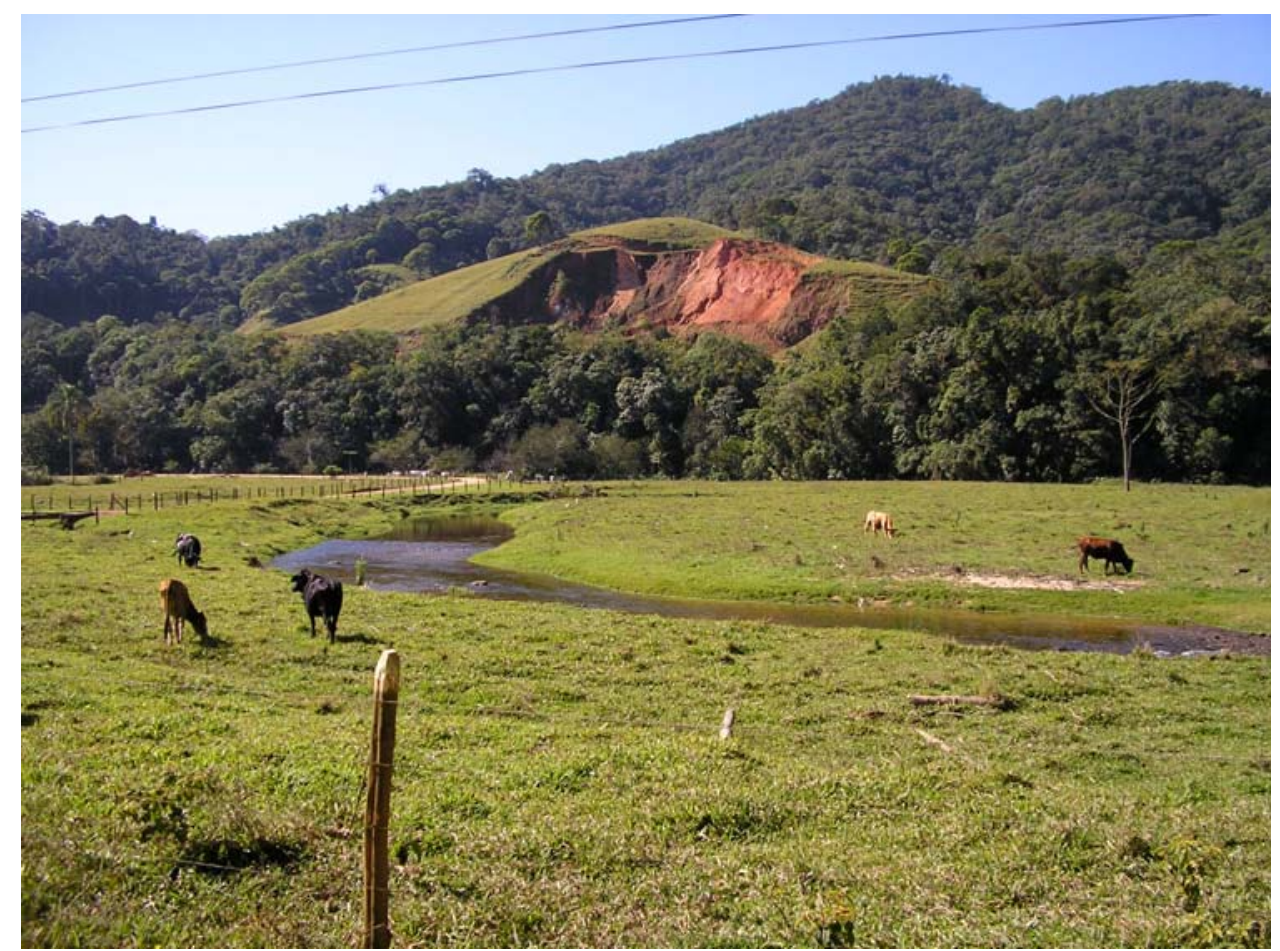

Figura 26 - Baixo curso do rio Farias. Detalhe de barras de meandros ( $1^{\circ}$ plano) e terraço ao fundo, até o contato da base do morro. Município de Antônio Carlos-SC. (Foto Edison Fortes, julho/2005).

A serra de São Miguel que pertence a Suíte Intrusiva Pedras Grandes, localizada a nordeste da bacia, é a região com elevado grau de dissecação e declividade superior a 25\%. O relevo apresenta-se rebaixado, com forte controle estrutural da drenagem. Nas encostas há longas e profundas cicatrizes de dissecação, provocadas pela ação erosiva sobre espessos mantos de alteração. Os elúvios são feições superficiais presentes de forma generalizada na paisagem. Os elúvios formado por material alterado permanece "in situ”. A presença dessas feições de elúvios evidencia a intensidade do intemperismo químico das rochas, tornando-se fonte de sedimentos para a atuação de processos erosivos (Fortes, 1996, p.33).

\section{A poluição do rio Biguaçu}

Em pesquisa realizada por Rosenéa Cerutti (1996), sobre a poluição doméstica na baía norte da área conurbada de Florianópolis, descreve-se que no município de Biguaçu, existem apenas indústrias de pequeno porte. “Os efluentes lançados na baía norte provém, portanto, de residências, edifícios comerciais, instituições públicas ou privadas e são compostos essencialmente por águas de banho, urina, fezes, restos de alimentos, papel, sabão, detergente e água de lavagem” (Cerutti, 1996, p.23). 
Em seu estudo, baseado em análises químicas e bacteriológica em estações amostrais, são reveladas elevadas e regulares contagens de coliformes fecais e coliformes totais, obtidos na desembocadoura do rio Biguaçu, sendo o local de maior contaminação da baía norte. Ao final de seu estudo, a pesquisadora cita algumas características da foz do rio Biguaçu: ocorre extremos de temperatura, baixo $\mathrm{pH}$, baixa salinidade e baixa transparência. $\mathrm{E}$ textualmente afirma: “Com o aumento da vazão do rio Biguaçu, as águas poluídas alastram-se por uma grande área, atingindo a baía de São Miguel e a ponta da Cruz, alterando a salinidade, o pH, a transparência e o teor de sólidos em suspensão desses locais” (Cerutti, 1996, p.96).

Alexandre Campos (2003), em pesquisa recente, analisou alguns parâmetros físicosquímicos da zona estuarina do rio Biguaçu. Constatou, que as margens do rio Biguaçu possuem baixo nível de preservação de vegetação, que reflete na turbidez das águas, com aumento considerável em dias chuvosos. O escoamento superficial é quase imediato. Em seu estudo, o autor (op. cit.) apresentou alguns resultados: a pluviosidade é um dos agentes reguladores da dinâmica do estuário do rio Biguaçu; nos meses de menor precipitação há uma predominância de estratificação na coluna de água e maior presença da cunha salina com a supressão de vegetação das margens, o que parece evidenciar, o papel da turbidez, no mecanismo de causa e efeito. O estudioso classifica o rio Biguaçu, quanto a sua morfologia, como um misto de estuário de planície costeira com vale de rio afogado (Campos, 2003, p.44).

De acordo com Cerutti (1996), na foz do rio Biguaçu onde os níveis de poluição por esgotos e elevada DBO permitem enquadrar o referido rio, como águas para navegação, contato secundário e manutenção da harmonia paisagística. Nas recomendações, cita a necessidade de implantação de estações de tratamento de esgoto. A curto prazo, deve a municipalidade incentivar e fiscalizar soluções locais para a destinação dos efluentes residenciais nas próprias comunidades, com o objetivo de minimizar o volume de contaminação bruta lançado nas baías. Outras ações levantadas, dizem respeito à preservação do manguezal do rio Biguaçu, impedindo novos aterros, interrompendo o lançamento de esgoto, de resíduos sólidos e a exploração de madeira e de outros recursos não permitidos (Cerutti, 1996, p.98). 


\section{Extração de areia do rio Biguaçu}

Durante trabalho de campo, localizaram-se duas dragas no rio Biguaçu. A primeira próximo a cidade de Antônio Carlos é uma pequena draga, não estava em atividade, estacionada na margem direita. Foi documentada com fotos. A segunda draga, localizada a montante da primeira, na localidade Usina, em Antônio Carlos, estava fora de operação e amarrada com corda sobre o leito do rio Biguaçu. No local, foi observada uma cava arredondada no leito do rio, onde é depositada areia trazida pela correnteza. Na margem direita há um depósito de areia (caixa metálica). Segundo informação de uma moradora (2006), ela só opera após ocorrer chuva forte. Segundo o Sr. Bertolino José Weber, morador de Canudos, em Antônio Carlos, existe mais uma draga no rio Biguaçu, próximo à foz do ribeirão Vermelho, que serve de divisa entre os municípios de Biguaçu e Antônio Carlos.

Próximo ao local da $1^{\text {a }}$ seção de medição de vazão, defronte à foz do rio Três Riachos, há um porto de areia (margem direita) do rio Biguaçu. Em trabalho de campo no local obtivemos informações com o Sr. Elson Junkes, proprietário da empresa Junkes Extração de Areia e Transporte. De acordo com o proprietário não há draga e sim uma bomba de sucção (bote), que retira água do rio Biguaçu e leva até a lagoa de mineração. Na mina Saudade, retira-se de 700 a $800 \mathrm{~m}^{3}$ de areia por mês. A licença ambiental é do período de 16/12/05 a 16/12/06. A área da mina é de 13 ha, dentro de uma propriedade rural (60 hectares) do próprio minerador, sendo 40 ha de pastagens e 7 ha de capoeirão.

Durante trabalho de campo realizado na bacia em março de 2007, segundo informações obtidas no local da mina Saudade, existia uma draga no leito do rio Biguaçu que operou durante 30 anos, até o ano de 2004, quando foi desativada. Em 2005, a extração de areia passou para a margem direita do referido rio (lagoa de mineração).

A profundidade do minério é de 4 a 5 metros na área da lagoa de mineração. A balsa de sucção retira a areia da mina e transfere para os depósitos (pilhas de areia). No local trabalham quatro pessoas (um na retroescavadeira, um na recepção e dois na balsa de sucção). 


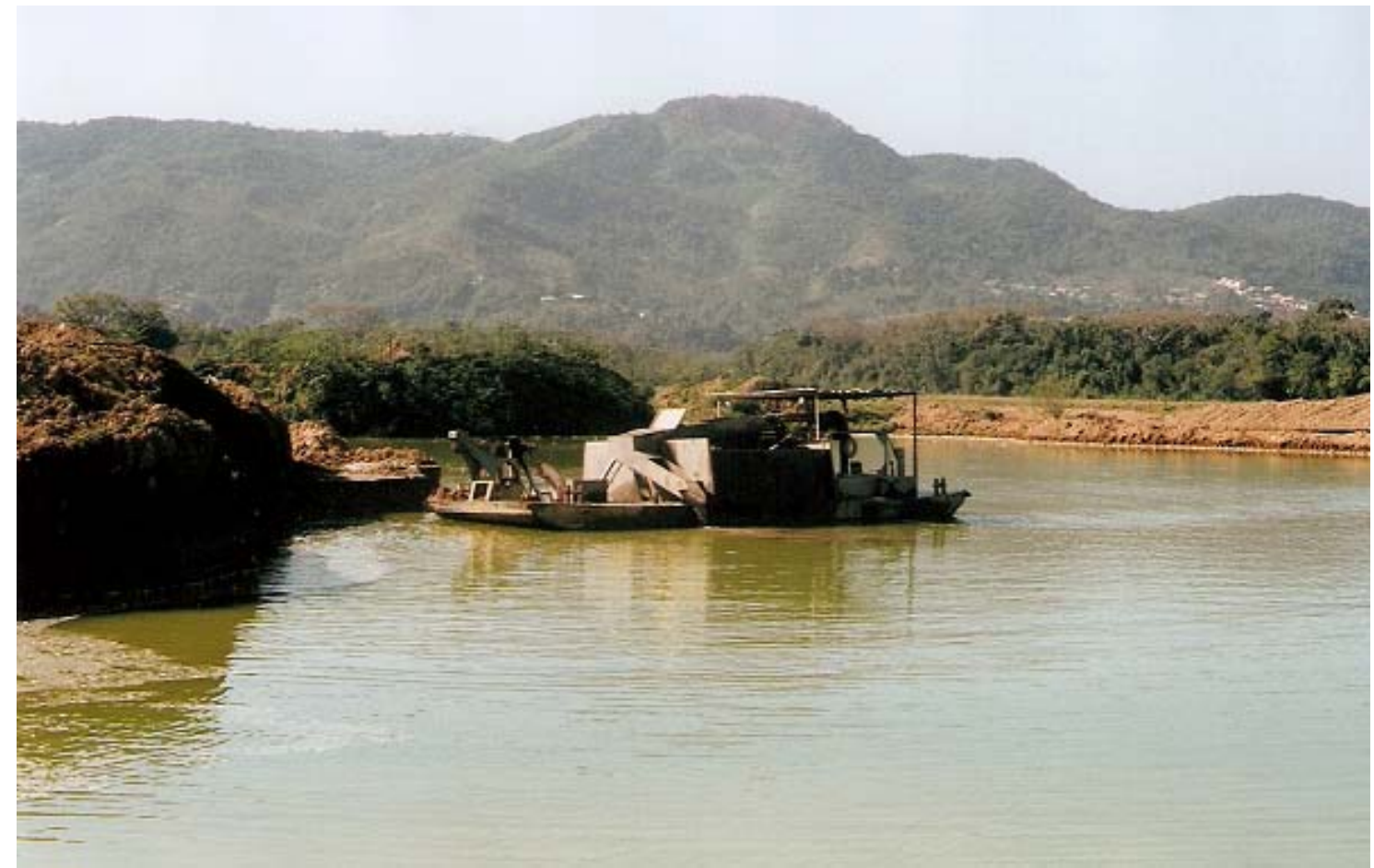

Figura 27 - Balsa de sucção em operação na lagoa de mineração de areia, na Mina Saudade, na margem direita do rio Biguaçu, município de Biguaçu-SC. (Foto: Vicente R. Silva, julho/2006).

O destino da areia da mina é para empresas de concreto, Concrebrás, Engevix, Supermix, situadas em Florianópolis. A área da mina Saudade é em formato de um triângulo e produz areia média nos tamanhos 2,4 a 2,7 mm. No local, na margem direita, há placa indicando “área de recuperação ambiental”, com o plantio de mudas de espécies nativas. Após o encerramento da atividade, o empresário pretende explorar a psicultura na lagoa de mineração (inf. verbal, julho/2006). 


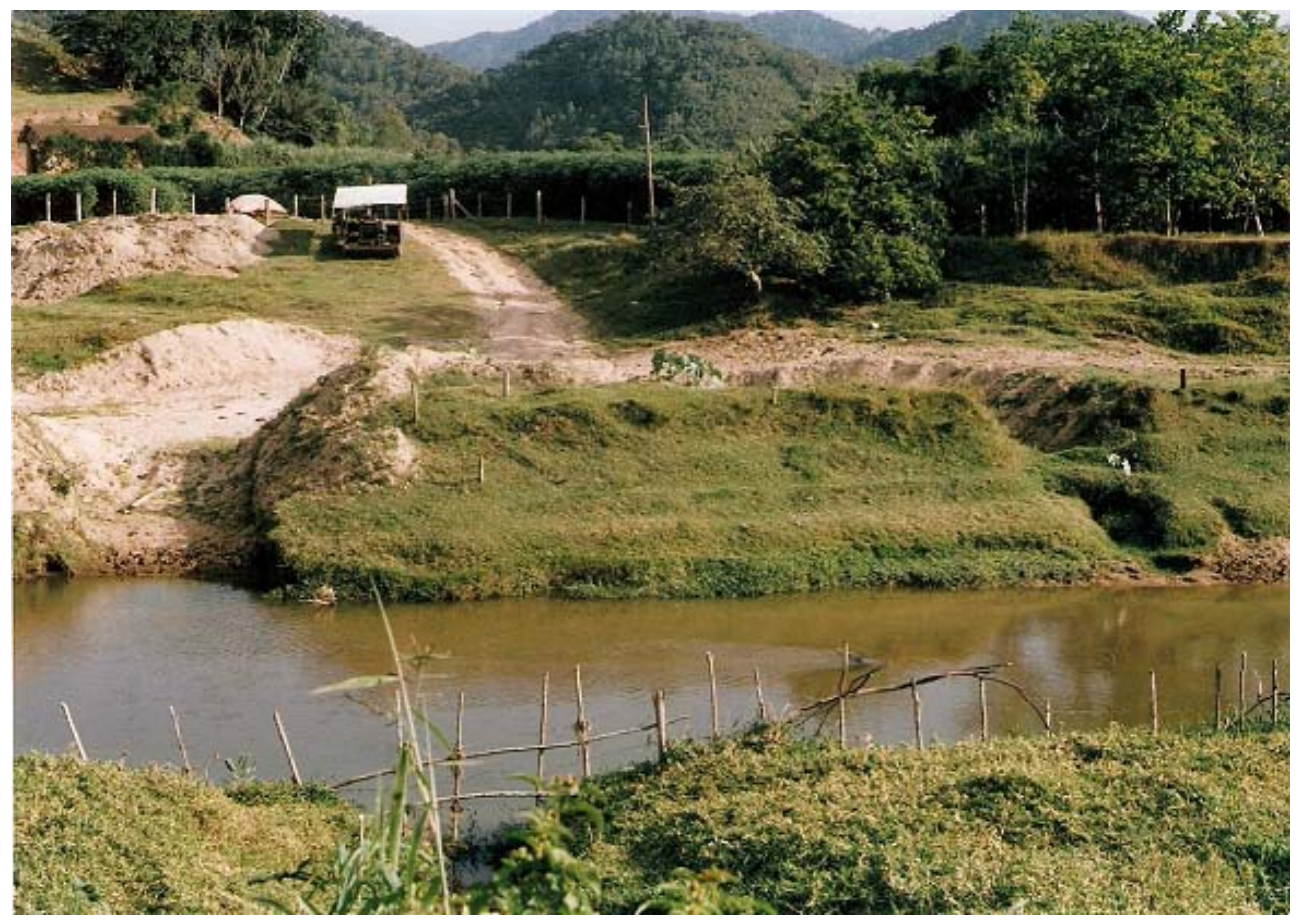

Figura 28- Vale do Rio Biguaçu, com draga de extração de areia, estacionada na margem direita do rio, a montante da cidade de Antônio Carlos - SC. ( Foto: Vicente R. Silva, abril/2006).

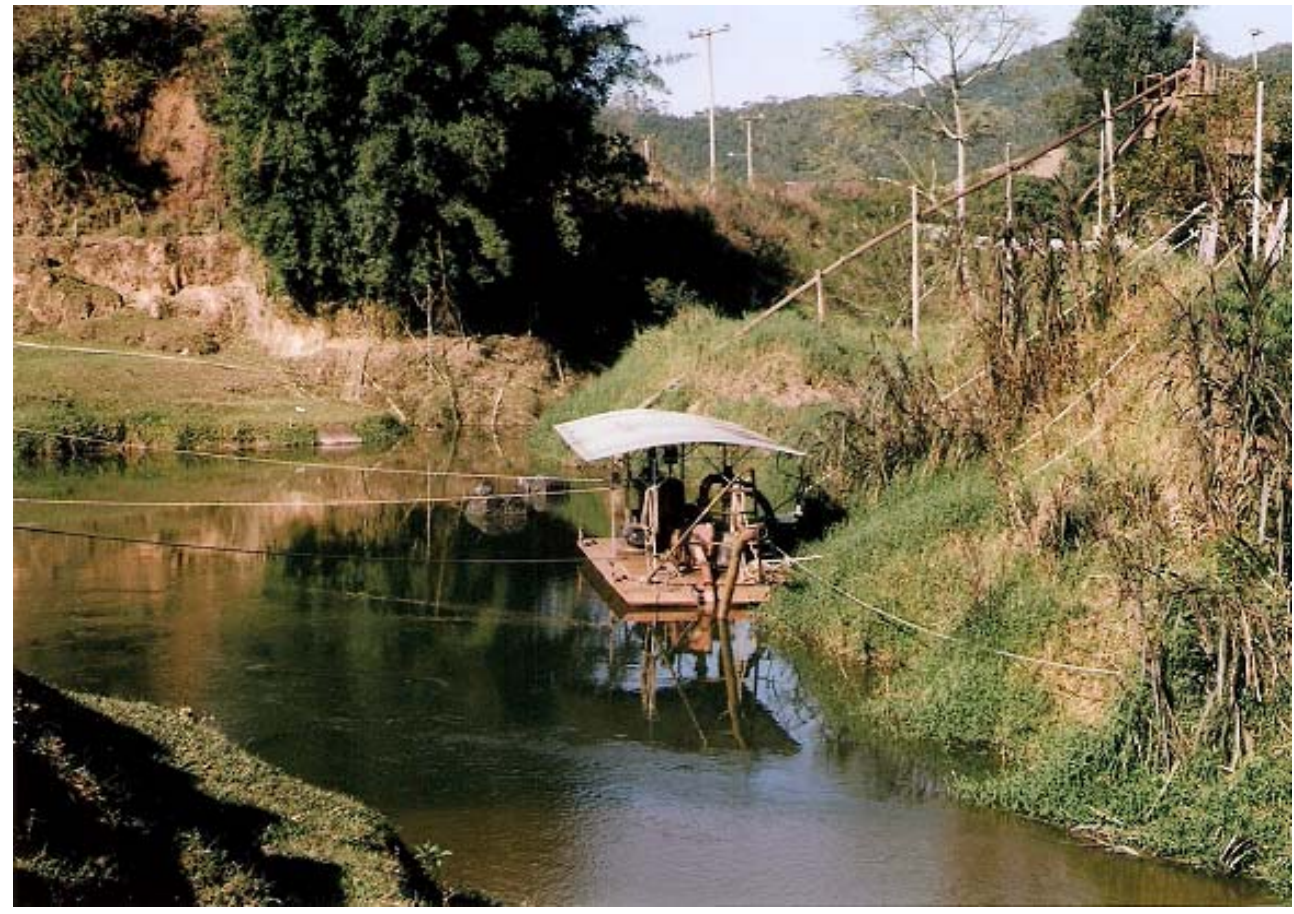

Figura 29 - Draga de extração de areia no leito do rio Biguaçu, na localidade Usina, no município de Antônio Carlos-SC. (Foto:Vicente R. Silva, julho/2006). 


\section{Aspectos hidrológicos}

Dados da medição

Na bacia do rio Biguaçu não há registros oficiais sobre a vazão do referido rio. O único dado é a medição realizada por Reitz apresentada no livro Alto Biguaçu: narrativa cultural tetrarracial, editada em 1988. Porém, o autor não informa qual a técnica utilizada e suas medições.O botânico Raulino Reitz (1988) elaborou uma tabela com medidas realizadas no rio Biguaçu, reproduzido abaixo:

Tabela 24 - Medição da profundidade do canal no baixo curso do rio Biguaçu, realizada em 1983.

\begin{tabular}{|c|c|c|c|c|}
\hline Ano & Local & Largura & $\begin{array}{c}\text { Profundidade maré } \\
\text { alta }\end{array}$ & $\begin{array}{c}\text { Profundidade maré } \\
\text { baixa }\end{array}$ \\
\hline 1983 & $\begin{array}{c}50 \text { m a montante BR- } \\
101\end{array}$ & 40,00 & 3,00 & 2,00 \\
\hline 1983 & Ponte da BR-101 & 45,00 & 4,00 & 3,00 \\
\hline 1983 & $\begin{array}{c}\text { Meia distância entre } \\
\text { ponte e foz }\end{array}$ & 60,00 & 3,00 & 0,00 \\
\hline 1983 & $\begin{array}{c}\text { Barra a 30 m da } \\
\text { margem esquerd }\end{array}$ & 85,00 & 0,80 & 1,20 \\
\hline 1983 & No canal da barra & 85,00 & 2,20 & \\
\hline
\end{tabular}

Fonte: Raulino Reitz (1988, p.406), (modificado). Medição realizada pelo autor dia 30/06/83. Obs.: Segundo o autor as medições ocorreram em épocas de fortes e longas precipitações, com águas no rio acima do normal.

Na pesquisa foram realizadas apenas duas medições. A primeira no inverno de 2005, nos dias 27/07/05 na $1^{\text {a }}$ seção (= $7 \mathrm{~km}$ da foz), a montante da foz do rio Três Riachos (margem esquerda do rio Biguaçu). Na $2^{a}$ seção, próxima desembocadura do rio Biguaçu, na cidade de Biguaçu, no dia 28/07/05. A $2^{\text {a }}$ medição de verão ocorreu no dia 28/02/06 em ambas seções e exatamente no mesmo local da medição anterior. 
Tabela 25 - Dados da medição de vazão no baixo curso do rio Biguaçu, no município de Biguaçu - SC.

\begin{tabular}{|c|c|c|c|c|c|}
\hline & Largura do rio & Área total & $\begin{array}{c}\text { Maior } \\
\text { profundidade }\end{array}$ & Vazão & $\begin{array}{c}\text { Altitude } \\
\text { aproximada }\end{array}$ \\
\hline $\begin{array}{c}1^{\mathrm{a}} \text { seção inverno } \\
(27 / 07 / 05)\end{array}$ & 17, 35 metros & $32,19 \mathrm{~m} 2$ & 3,63 metros & $3,62 \mathrm{~m} 3 / \mathrm{s}$ & 5,6 metros \\
\hline $\begin{array}{c}1^{\text {a }} \text { seção verão } \\
\text { (28/02/06) }\end{array}$ & 17,35 metros & $25,08 \mathrm{~m} 2$ & 3,18 metros & $2,44 \mathrm{~m} 3 / \mathrm{s}$ & 5,6 metros \\
\hline $\begin{array}{c}2^{\mathrm{a}} \text { seção inverno } \\
(28 / 07 / 05)\end{array}$ & 57,00 metros & $97,03 \mathrm{~m} 2$ & 2,83 metros & $14,55 \mathrm{~m} 3 / \mathrm{s}$ & 3,0 metros \\
\hline $\begin{array}{c}2^{\mathrm{a}} \text { seção verão } \\
(28 / 02 / 06)\end{array}$ & 58,00 metros & $99,61 \mathrm{~m} 2$ & 3,07 metros & $26,89 \mathrm{~m} 3 / \mathrm{s}$ & 3,0 metros \\
\hline
\end{tabular}

Fonte: pesquisa de campo (julho/2005 e fevereiro/2006)

Obs.: $1^{\mathrm{a}}$ seção, leito lamoso (substrato). Uso da terra nas margens: pastagens, com diminuta vegetação ciliar. Na $2^{\mathrm{a}}$ seção, substrato lamoso (cor preta), maré baixa.

Obs.: Na $2^{\mathrm{a}}$ seção (próximo a foz), foi realizado dragagem do canal do rio Biguaçu em 1994, sendo o material retirado do fundo, depositado na margem esquerda, próximo à ponte sobre a BR-101. A margem direita é área urbana de Biguaçu e na margem esquerda temos o manguezal. Na $1^{\mathrm{a}}$ seção, a montante, o canal do rio Biguaçu foi retificado, numa extensão de 16 km entre 1966 e 1970. 
Seção topográfica transversal do canal do rio Biguaçu - SC -27/07/2005 Seçâo 01 (inverno)

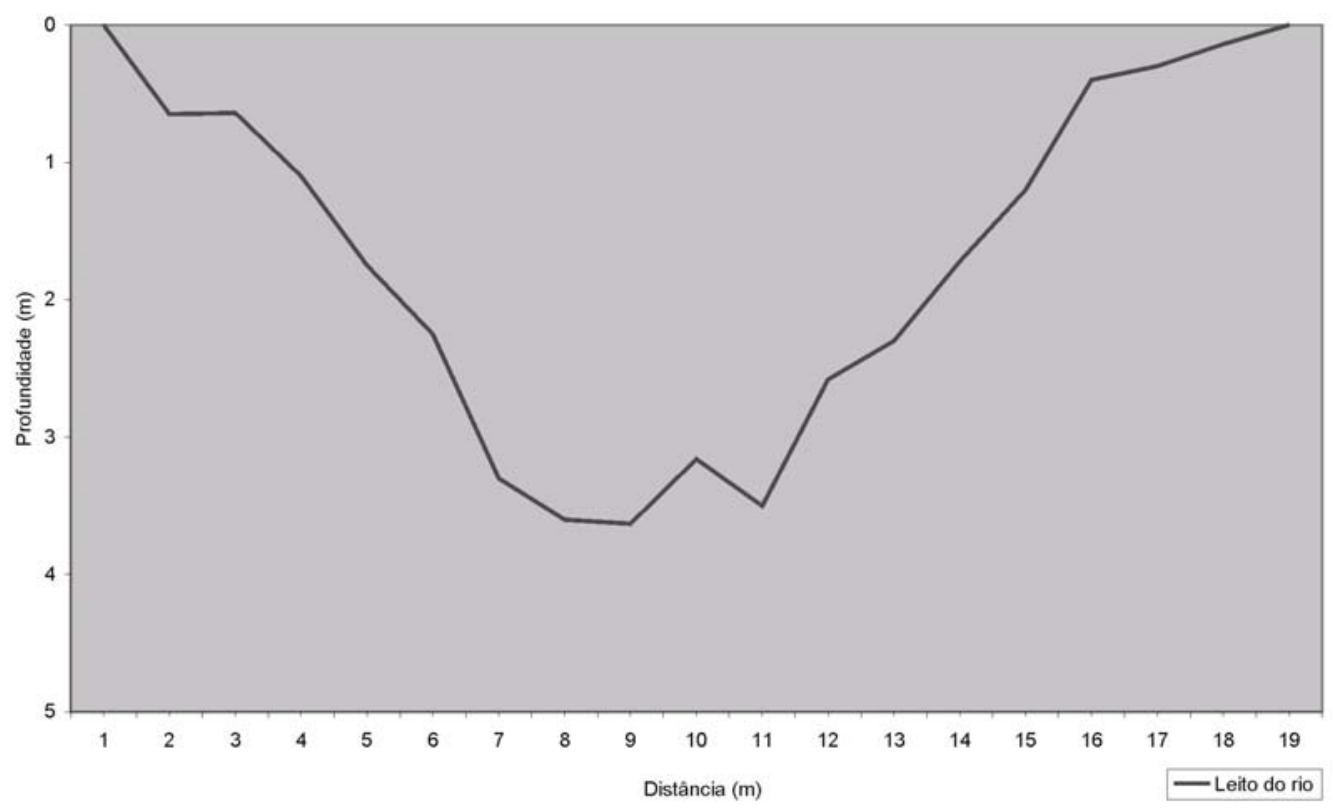

Seção topográfica transversal do canal do rio Biguaçu - SC -28/02/2006 Seção 01 (verão)

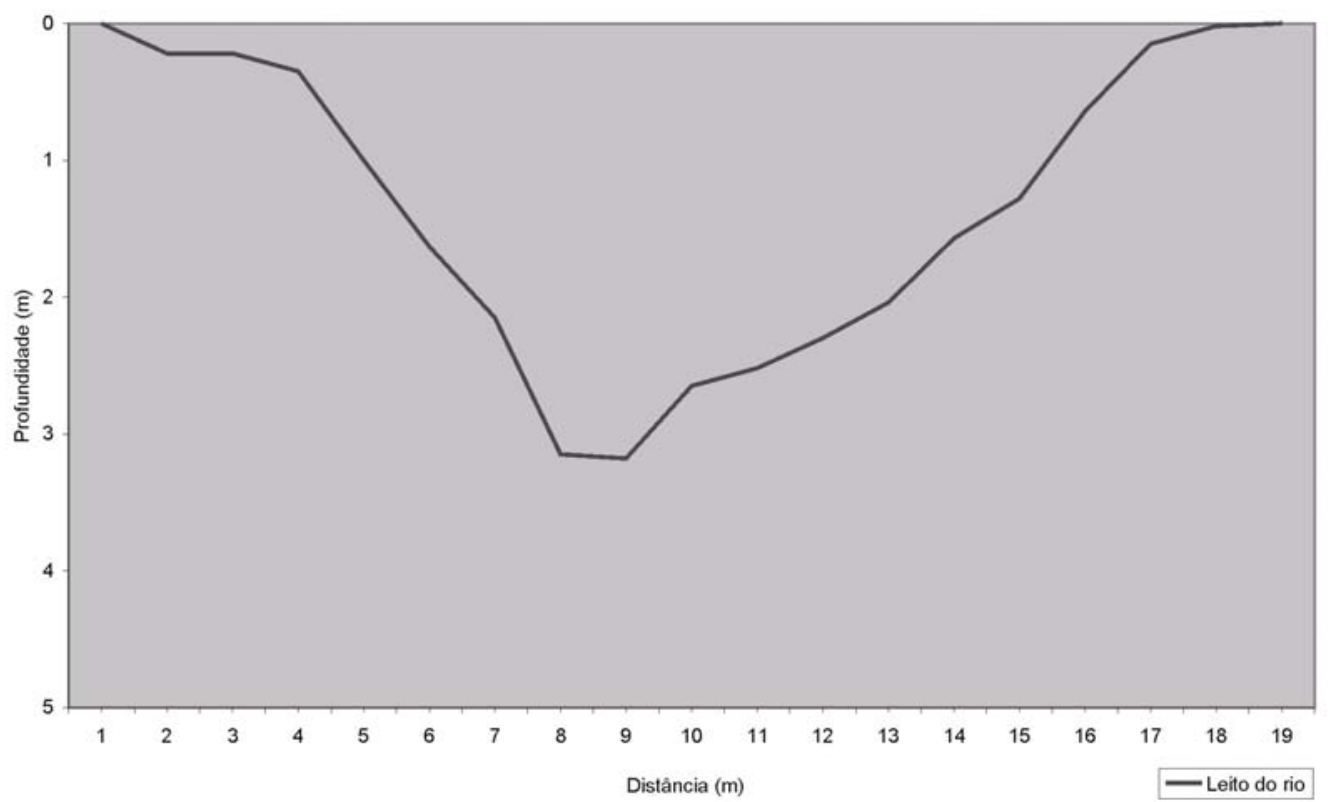

Figura 30 - Seção topográfica transversal do canal do rio Biguaçu-SC, Seção 1. 
Seção topográfica transversal do canal do rio Biguaçu - SC -28/02/2006 Seçāo $\mathscr{~ ( v e r a ̂ o ) ~}$

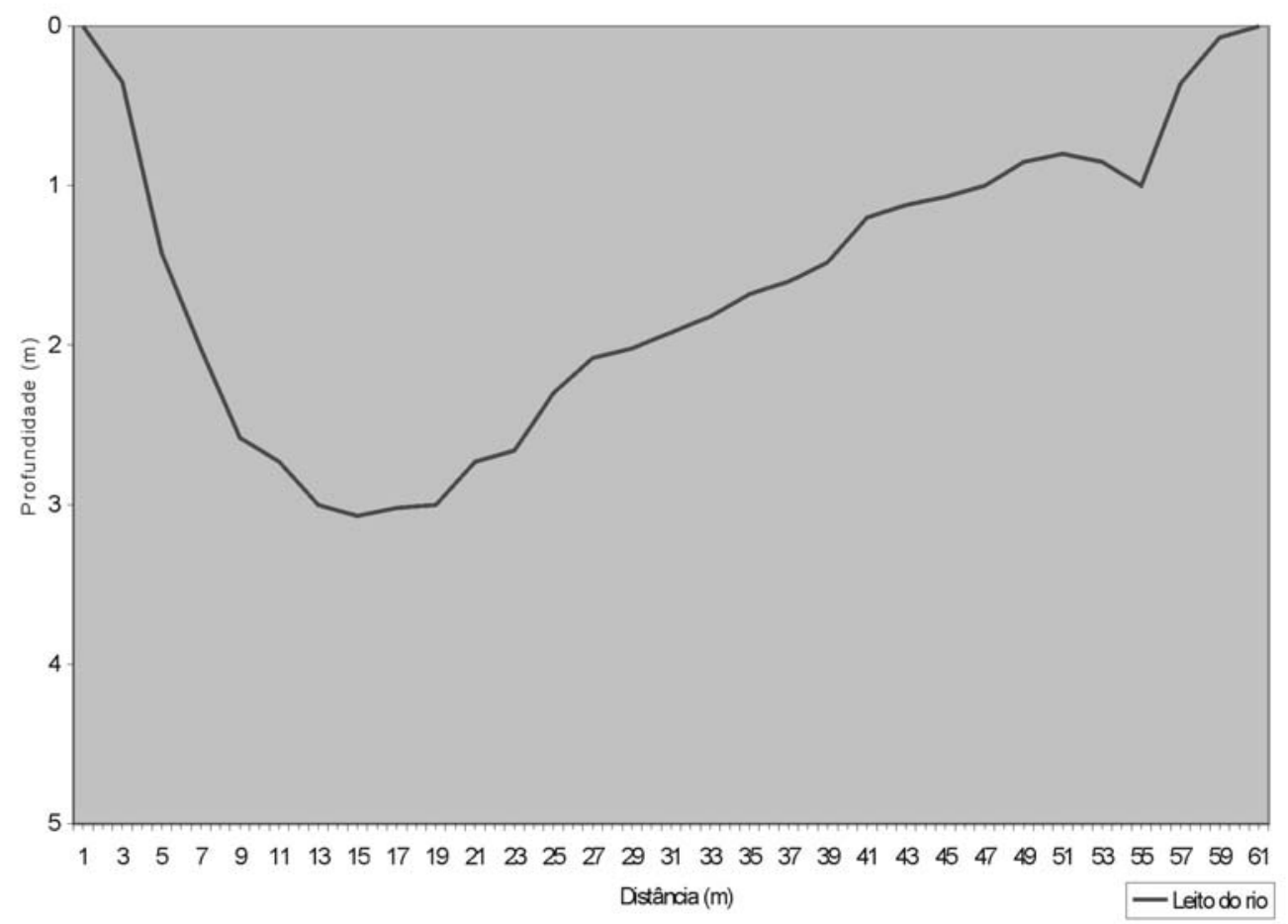

Seção topográfica transversal do canal do rio Biguaçu - SC -28/07/2005 Seção 02 (inverno)

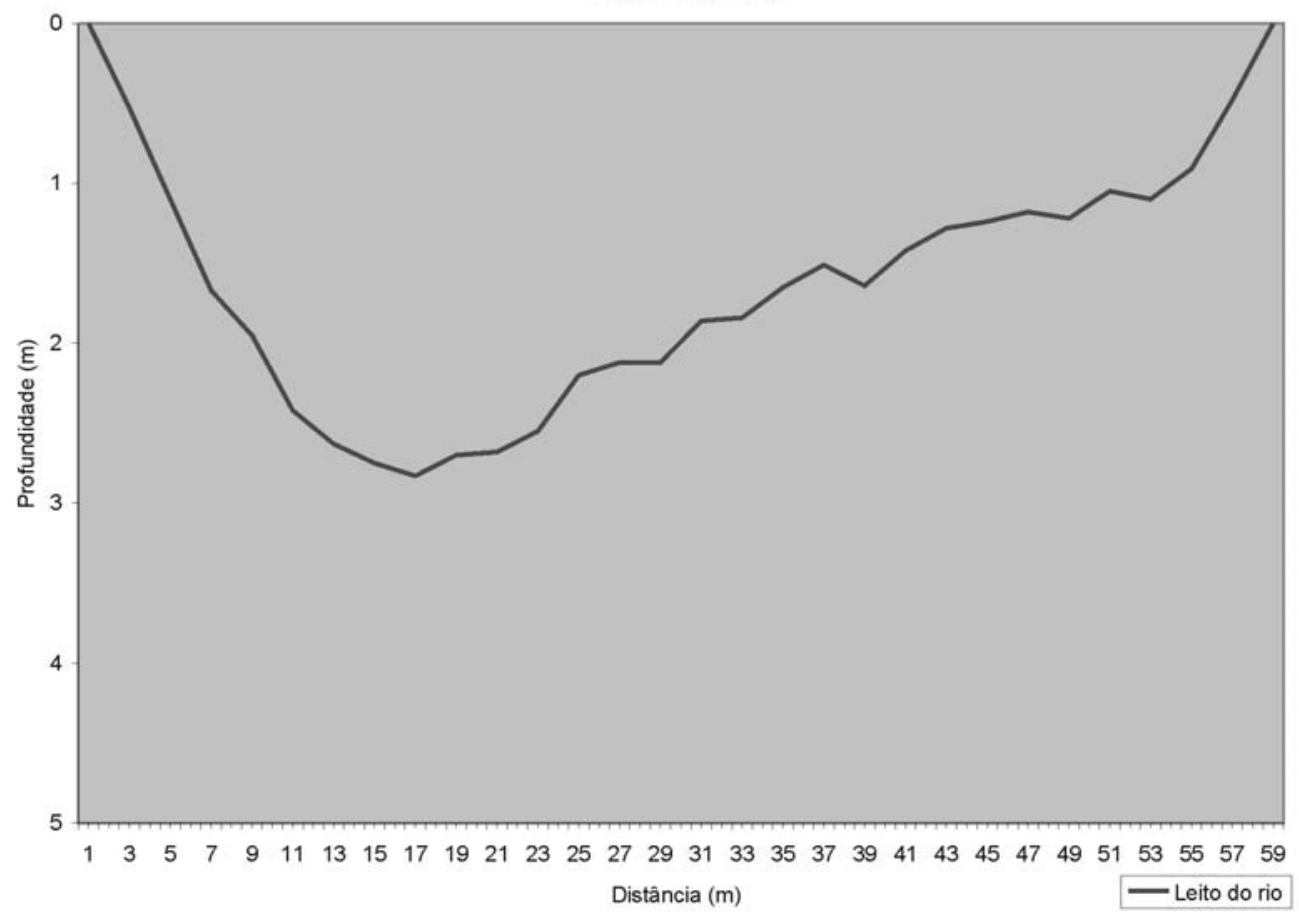

Figura 31- Seção topográfica transversal do canal do rio Biguaçu-SC, Seção 2. 
$\mathrm{Na}$ área de pesquisa a maioria dos principais rios que integram o rio Biguaçu tem suas nascentes na porção oeste da bacia, nos domínios do embasamento cristalino, que corresponde ao Planalto de Cimeira. Nos seus altos cursos, a cobertura vegetal predomina a mata atlântica. Nos médios e baixos cursos, a exploração da terra por agricultura e pecuária, provocou a retirada da vegetação natural. Assim sendo, é elevada a carga em suspensão transportada pelo rio Biguaçu, que tem destino final a baía norte. A compartimentação topográfica da bacia, constituída por planície costeira, planalto e serras, acaba por influenciar na distribuição pluviométrica, onde os totais de chuvas são mais elevados na porção oeste, no município de Antônio Carlos.

Na pesquisa realizada por Fabiano Oliveira (2007), na região de Joinville-SC, sobre o aporte de sedimentos em suspensão na baía de Babitonga, são citadas as dez bacias estudadas, dando destaque à bacia do rio Cubatão com 480,69 km2, que corresponde a 70,2\% do total do conjunto das bacias. O referido autor descreve que o rio Cubatão possui canal artificial de 12 km de extensão, construído na década de 1950, no baixo curso, visando diminuir as constantes inundações (Oliveira, 2007, p.58). Caso semelhante ocorreu no rio Biguaçu e outros tributários que foram retificados nas décadas de 1960 e 1970, para combater as enchentes nos municípios de Antônio Carlos e Biguaçu.

Nos estudos de vazões, “a sazonalidade das vazões acompanha a sazonalidade da precipitação” (Oliveira, 2007, p.199). No estudo, o autor citado, obteve a média de vazões do rio Cubatão para o período de medições pontuais mensais de 14, 80 m3/s (op.cit., p.202). Na bacia do rio Biguaçu com área de 389,7 km2, obteve-se em julho de 2005, na $2^{a}$ seção (perto da foz), a vazão de 14,55 m3/s, utilizando a técnica de flutuador na medição. Esse dado obtido em nossa pesquisa, apesar de não ser preciso, aproxima-se da média encontrada no estudo de Oliveira, finalizado em março de 2007.

Vários autores que pesquisaram sobre o comportamento hidrossedimentológico a nível mundial em diferentes condições ambientais e humanas, argumentam “ em consenso que as concentrações de sedmentos em suspensão no sistema fluvial, variam no tempo e no espaço, em diferentes escalas, (...)”(Oliveira, 2007, p.217). O mesmo autor acrescenta: “Essa sazonalidade está associada a sazonalidade climática, representada pela precipitação, mas 
também a fatores sócio-econômicos e mesmo culturais ligados ao uso da terra, neste caso não alteração sazonal propriamente dita, mas como modificações ao longo do tempo” (op.cit., p.218).

Em suas considerações finais o autor (op.cit.,p.269), argumenta que a bacia do rio Cubatão, com 481 km2 representa 54,2\% da área total de contribuição hidrográfica da baía de Babitonga, onde ocorre há décadas o processo de assoreamento. Esse processo de assoreamento crescente também acontece na foz do rio Biguaçu no litoral central de Santa Catarina. 


\subsection{5-Características dos solos}

Solos da bacia do Rio Biguaçu.

São apresentadas abaixo, seis definições de solos:

a)“Pode definir-se como o meio natural para o desenvolvimento das plantas terrestres, tal como se formou (solo dito natural), ou mais ou menos modificado como resultado da sua utilização pelo homem" (Costa, 1985, p.14); b) (...) "capa superficial da litosfera até onde penetra ação do intemperismo" Glinka apud Vieira (1998, p.4). Foi a partir das análises de Glinka que o perfil do solo tornou-se a unidade fundamental para o estudo do solo, sendo um produto da decomposição da rocha pelo intemperismo;

c) "Solo é superfície inconsolidada que recobre as rochas e mantém a vida animal e vegetal da Terra. É constituído de camadas que diferem pela natureza física, química, mineralógica e biológica, que se desenvolvem com o tempo, sob a influência do clima e da própria atividade biológica" (Vieira, 1988, p.8);

d)"Solo nada mais é do que o resultante da ação conjunta dos agentes intempéricos sobre restos minerais depositados e enriquecidos de detritos orgânicos" (Vieira, 1988, p.9). Um solo verdadeiro não pode se formar sem que haja no material a presença de decomposição da matéria orgânica;

e)(...) "coleção de corpos naturais que contém matéria viva e é resultante da ação do clima e da biosfera sobre a rocha, cuja, transformação em solo se realiza durante certo tempo e é influenciada pelo tipo de relevo" (Lepsch, 1982, p.14);

f) (...) "é uma coleção de corpos naturais constituídos por partes sólidas, líquidas e gasosas, trimensionais dinâmicos, formados por materiais minerais e orgânicos, que ocupam a maior parte do manto superficial das extensões continentais do nosso planeta, contém matéria viva e podem ser vegetados na natureza, onde ocorrem" (Embrapa, 1999, p.5).

Critérios adotados para a caracterização e separação das classes de solos, de acordo com Gerco ( $3^{\text {a }}$ fase), definidos pelo IBGE (2003).

Material Orgânico: "é constituído por compostos orgânicos, podendo conter proporção variavelmente maior ou menor de material mineral,"(...). Com base no teor de material orgânico, temos três tipos de propriedades: álico caracteriza solos que possuem saturação 
com alumínio igual ou superior a 50\%; distrófico, caracteriza solos que apresentam saturação de bases (V\%) e de alumínio inferior a $50 \%$ e eutrófico, caracteriza solos que apresentam saturação de bases (V\%) igual ou superior a 50\% (Shimizu; Vieira; Moser, 2003, p.13).

Outro aspecto da propriedade dos solos é em relação a atividade da argila, sendo apresentada de duas formas: argila de atividade alta (Ta) e argila de atividade baixa $(\mathrm{Tb})$. Para a agricultura, a argila de atividade alta (Ta) é melhor, pois a argila absorve mais água (argila expandida), facilitando o manejo do solo. Na bacia do rio Biguaçu, predomina a argila de atividade baixa $(\mathrm{Tb})$.

No aspecto da classe de textura que ocorre na área de estudo: a) Textura muito argilosa: classe textural com mais de $60 \%$ de argila. b) Textura argilosa: compreende as classes texturais argila, argila arenosa, argilasiltosa, franco-argiloso e franco-argiloso-siltoso, com teores de argila entre 35 e $60 \%$. c) textura média: compreende as classes texturais com menos de $35 \%$ de argila de mais de $15 \%$ de areia, exceto areia e areia franca. d) Textura siltosa: compreende parte de classes texturais que tenham mais de $50 \%$ de silte, menor que $35 \%$ de argila e menos que $15 \%$ de areia.

Tipos de horizonte A - a)Proeminente: semelhante ao horizonte A chernozêmico, dintinguindo-se deste essencialmente por apresentar saturação de bases superior a $50 \%$. Ocorre na bacia, em áreas mais restritas. b) Moderado: horizonte mineral, apresentando teores de carbono orgânico variável, espessura e/ou cor que não caracterize um horizonte A chernozêmico ou proeminente. Trata-se de um horizonte mais delgado, com baixo teor de matéria orgânica. É o tipo mais comum encontrado na área de pesquisa.

Tipo de horizonte B - a)-Horizonte B textural: é um horizonte subsuperficial que pode também ser encontrado na superfície do solo se o solo for truncado por erosão, e caracterizase pelo incremento de argila em relação aos demais horizontes, principalmente ao A, resultante de acumulação ou concentração de processo como iluviação, formação "in situ" herdado do material de originário, infiltração de argila, destruição ou perda de argila do horizonte A por erosão diferencial (Shimizu; Vieira; Moser, 2003, p.15-16). É típico da classe de solos argissolos, encontrados em toda a bacia do rio Biguaçu.

b)-Horizonte B incipiente: É um horizonte subsuperficial subjacente ao A, Ap ou A3, que sofreu alteração física e química em grau não muito avançado, porém suficiente para o 
desenvolvimento de cor ou de estrutura (Shimizu; Vieira; Moser, 2003, 16). O horizonte B incipiente é comum na classe de solos Cambissolos, que são dominantes na área de estudo.

\section{Fases do relevo}

a)plano: superfície de topografia esbatida ou horizontal com declives menores que $3 \%$. suave ondulado: superfície topográfica pouco movimentada, apresentando declives de 3 a 8\%. c) ondulado: superfície topográfica pouco movimentada com predominância de declives variando de 8 a 20\%. d) forte ondulado: superfície de topografia movimentada com predominância de declives de 20 a 45\%. e) montanhoso: superfície topográfica muito movimentada, representada por morros, montanhas, maciços e alinhamentos montanhosos, com declives da ordem de 45 a 75\%. f) escarpado: superfície topográfica extremamente movimentada, com predominância de formas abruptas, com declives maiores que $75 \%$ (Shimizu; Vieira; Moser, 2003, p.16).

No aspecto fases do relevo, na área de estudo predomina o tipo suave ondulado, seguido, em ordem decrescente, em área de abrangência, os tipos: de plano, ondulado, forte ondulado e montanhoso. O tipo escarpado só ocorre em áreas restritas, nos divisores topográficos da bacia, no extremo oeste da bacia (Serra do Macaco Branco).

\section{Classe de drenagem}

a)bem drenados: a água é removida do solo com facilidade, porém não rapidamente e os solos dessa classe, comumente, apresentam texturas argilosa ou média.

b) moderadamente drenado: a água é removida do solo um tanto lentamente, de modo que o perfil permanece molhado por pequena, mas significativa parte do tempo. Estes solos, em geral, apresentam uma camada de permeabilidade lenta ou imediatamente abaixo do solum. O lençol freático acha-se imediatamente abaixo do solum, afetando a parte inferior do horizonte B, por adição de água através de translocação lateral interna ou alguma combinação dessas condições (Shimizu; Vieira; Moser, 2003, p.16).

c) imperfeitamente drenado: a água é removida do perfil tão lentamente que o solo permanece molhado por grande parte do tempo. O lençol freático, geralmente, está à superfície ou próximo dela durante considerável parte do ano. As condições de má drenagem são devidas ao lençol freático elevado, camada lentamente permeável no perfil, adição de água através de 
translocação lateral interna ou alguma combinação dessas condições. É frequênte a ocorrência de mosqueado no perfil e características de gleização.

d) muito mal drenado: a água é removida do solo tão lentamente que o lençol freático permanece a superfície ou próximo dela, durante maior parte do ano. Solos com drenagem dessa classe ocupam áreas planas ou depressões, onde há frequentemente estagnação. São comuns solos com características de gleização e/ou acúmulo, pelo menos superficial de matéria orgânica (Shimizu; Vieira; Moser, 2003, p.17).

Nesse aspecto da drenagem, o tipo bem drenado é típico da classe de solos argissolos vermelho-amarelos distróficos. Já o tipo moderadamente drenado, é comum na classe de solos cambissolos flúvicos e cambissolos háplicos. Os tipos, imperfeitamente drenados e mal drenados, ocorrem na classe de solos gleissolos melânicos e gleissolos háplicos. E por último, o tipo muito mal drenado, compreende a classse de solos neossolos flúvicos, neossolos quartzarênicos. Ocorrem também, na pesquisa definidos como tipos de terrenos, os solos indiscriminados de mangue (SM), localizados próximo da foz do rio Biguaçu, na baía norte.

Fases de pedregosidade

a) Não pedregosa: quando não há ocorrência de calhaus e/ou matacões na superfície e/ou na massa do solo, ou a ocorrência é insignificante e não interfere na aração do solo, ou é significante, sendo, porém, facilmente removível.

b) Pedregosa: ocorrência de calhaus e/ou matacões, ocupando 3 a 15\% da massa do solo e/ou da superfície do terreno (distanciando-se por 0,75 a 1,5 metros), tornando impraticável o uso de maquinaria, com exceção de máquinas leves e implementos agrícolas manuais. Solos nessa classe de pedregosidade podem ser utilizados como áreas de preservação da flora e da fauna (Shimizu; Vieira; Moser, 2003, p.17). As fases não pedregosa e pedregosa estão presentes em uma (1) unidade de mapeamento de Cambissolo Háplicos (CXbd5) delimitadas no mapa de solos, próximo ao rio Farias, no seu alto curso, no município de Antônio Carlos.

\section{Classe de erosão}

a) Ligeira: o solo apresenta menos de $25 \%$ do horizonte $\mathrm{A}$ ou da camada arável removidos quando está foi inteiramente construída pelo horizonte A. Solos que apresentam horizonte A original pouco espesso $(20 \mathrm{~cm})$, nos quais a camada arável é constituída de horizonte A e 
parte do B, também se enquadram nesta classe de erosão. Os solos enquadrados nesta classe apresentam sulcos superficiais e ocasionais sulcos rasos, que podem ser cruzados por máquinas agrícolas e que são desfeitos pelas práticas normais de preparo do solo. Nesta classe de erosão os solos, em geral, não foram suficientemente afetados a ponto de alterar o caráter e a espessura do horizonte A (Shimizu; Vieira; Moser, 2003, p.17-18).

b) Moderada: o solo apresenta 25 a 75\% do horizonte A removido na maior parte de área, apresentando frequentes sulcos rasos, que não são desfeitos pelas práticas normais de preparo do solo. A camada arável, em geral, consiste em remanescentes do horizonte A, em alguns casos da mistura dos horizontes A e B (Shimizu; Vieira; Moser, 2003, p.18). Predomina na bacia do rio Biguaçu a classe de erosão do tipo ligeira e moderada.

Descrição das classes de solos

As classes de solos identificadas na área da bacia do rio Biguaçu, pela equipe de solos do IBGE (2003), de Florianópolis: argissolos vermelho-amarelos, cambissolos flúvicos, cambissolos háplicos, gleissolos melânicos, gleissolos háplicos, neossolos flúvicos e neossolos quartzarênicos. O enquadramento das classes de solos foi de acordo com a nova classificação de solos da Embrapa (1999). A classe de solos Cambissolos Flúvicos está descrita no Sistema Brasileiro de Classificação de Solos da Embrapa, 2a edição, (versão preliminar), 2005.

Argissolos Vermelho-Amarelos distróficos

Os solos argissolos são típicos das regiões de florestas, de clima quente e úmido, com perfis bem desenvolvidos e a profundidade média de 1,5 a 2,0 metros. São moderadamente ou bem intemperizados, com diferenciação marcante entre os horizontes (Lepsch, 1982, p.84). Segundo, o autor, os podzólicos vermelho-amarelos (argissolos) ocorrem em situações de relevo mais acidentado. O pesquisador (op. cit.) acrescenta que a maior parte desses solos são utilizáveis para agricultura, desde que não ocorram em áreas com declividade elevada, pois são extremamente susceptíveis à erosão hídrica (Lepsch, 1982, p.87).

Em geral, são solos ácidos (distróficos) e de baixa fertilidade, necessitando de corretivos e fertilizantes para prática agrícola. Os solos podzólicos vermelho-amarelos (argissolos), são solos bem drenados, com delgada camada orgânica (horizonte O) (Vieira, 1988, p.393). 
No relatório técnico de solos do IBGE (2003), os argissolos são considerados solos minerais, não hidromórficos, com horizonte A seguido de horizonte $\mathrm{B}$ textural, não plíntico, com considerável iluviação de argila do horizonte A para o B. Os horizontes têm sequência A, Bt, C.

É nítida a identificação dos horizontes devido a grande variação nas características morfológicas e analíticas como a cor, textura, estrutura entre os horizontes. Em geral, os argissolos apresentam textura variada podendo ocorrer cascalhos, calhaus e matacões.

A utilização mais adequada para esses solos é o reflorestamento, pastagens ou cultura permanentes (Shimizu; Vieira; Moser, 2003, p.58). Na bacia do rio Biguaçu, os argissolos possuem grandes áreas na porção nordeste e oeste, com cobertura dominante por capoeirões (oeste) e na porção nordeste da bacia, com cobertura de vegetação secundária e usos com lavoura temporária e pastagens.

Foram identificadas cerca de 9 unidades de mapeamento, pela equipe de solos do IBGE e delimitados os polígonos no mapa de solos e inseridas as respectivas legendas. As legendas foram descritas a seguir:

\section{Argissolos Vermelho-Amarelos distróficos}

a) PVAd1 - argissolos vermelho-amarelos distróficos típicos, TB, textura média/argilosa, A moderado, relevo suave ondulado;

b)PVAd2 - argissolos vermelho-amarelos distróficos típicos, Tb, textura média/argilosa, A moderado, relevo ondulado (inclusão de cambissolos háplicos Tb distróficos típicos, textura argilosa, A moderado).

c) PVAd3 - argissolos vermelho-amarelos distróficos típicos, $\mathrm{Tb}$, textura média pouco cascalhenta/argilosa pouca cascalhenta, A moderado, relevo suave ondulado e ondulado (inclusão de cambissolos háplicos Tb distróficos típicos, textura argilosa pouca cascalhenta, $\mathrm{A}$ moderado).

d) PVAd4- argissolos vermelho-amarelos distróficos típicos, $\mathrm{Tb}$, textura média pouco cascalhenta/argilosa pouco cascalhenta, A moderado, relevo ondulado.

e) PVAd5 - argissolos vermelho-amarelos distróficos típicos, textura argilosa e muito argilosa, A moderado, relevo forte ondulado e ondulado. 
f) PVAd6 - argissolos vermelho-amarelos distróficos típicos, Tb, textura média/argilosa, A moderado, relevo ondulado e suave ondulado + cambissolos háplicos Tb distróficos típicos, textura média e argilosa, A moderado, relevo suave ondulado.

g) PVAd7 - argissolos vermelho-amarelos distróficos típicos, Tb, textura média/argilosa, A moderado + cambissolos háplicos $\mathrm{Tb}$ distóficos típicos, textura argilosa pouco cascalhenta, $\mathrm{A}$ moderado, relevo montanhoso e forte ondulado.

h) PVAd8 - argissolos vermelho-amarelos distróficos típicos, Tb, textura média/argilosa cascalhenta, A moderado + cambissolos h'plicos Tb distróficos típicos textura argilosa pouco cascalhenta, A moderado e proeminente, relevo forte ondulado.

i) PVAd9 -argissolos vermelho-amarelos distróficos típicos, $\mathrm{Tb}$, textrua média pouco cascalhenta/argilosa cascalhenta, A moderado + cambissolos háplicos Tb distróficos típicos, textura argilosa pouco cascalhenta, A moderado, relevo ondulado.

\section{Cambissolos.}

São solos formados por horizonte B incipiente ou câmbico. Em geral, apresentam certo grau de desenvolvimento, no entanto, ainda não suficiente para decompor totalmente os minerais primários de fácil intemperização. Apesar disso, o processo de formação do solo já modificou bastante o material de origem. Trata-se de solos de profundidade mediana, moderados a bem drenados, (...) (Vieira, 1988, p.429). "O cambissolos é considerado como pouco desenvolvido por causa do horizonte B que apresenta pequena espessura e pouca diferenciação" (...) (Lepsch, 1982, p.110).

No projeto Gerco ( $3^{\mathrm{a}}$ fase), os cambissolos são caracterizados por "solos minerais, não hidromórficos, com horizonte $\mathrm{B}$ incipiente, acentuada a imperfeitamente drenados, não plínticos e textura franco arenosa ou mais fina. A profundidade varia de raso a profundo; com sequência de horizonte A, Bi e C. Apresenta horizonte A variando de moderado, proeminente ou húmico, em geral, não muito espesso, podendo inclusive estar ausente em áreas de declividades acentuadas, devido a erosão" (Shimizu; Vieira; Moser, 2003, p.246).

Os cambissolos apresentam grande variação quanto ao material de origem, ocorrendo em variadas condições climáticas. Essa diversidade de material de origem, permite que os solos sejam álicos, distróficos e eutróficos. A textura pode variar de média até muito argilosa 
e drenagem variável. Os solos podem ser de rasos a profundos e o relevo de plano a montanhoso (Shimizu; Vieira; Moser, 2003, p.247).

Os cambissolos quando originários de granito do pré-cambriano, em geral, apresentam argila de atividade baixa e textura argilosa. Quando originados da Suíte Intrusiva Valsungana (presente na bacia), possuem textura argilosa ou muito argilosa, com presença ou não de cascalhos e areia grossa ao longo do perfil (op. cit.).

O cambissolos é a classe de solos que ocupa a maior área na bacia do rio Biguaçu. Esses solos podem ocorrer com coberturas mais recentes de depósitos aluvionares no período holoceno, no quaternário. São solos diversificados devido a diferentes tipos de sedimentos depositados, podendo ser álicos, distróficos ou eutróficos. A atividade de argila baixa a alta e textura variando de média a muito argilosa (Shimizu; Vieira; Moser, 2003, p.248).

Para a classe dos cambissolos foram identificadas no mapa de solos do Gerco- $3^{\text {a }}$ fase (Shimizu; Vieira; Moser, 2003), 9 (nove) classes, sendo 5 classes de Cambissolos Háplicos e 4 classes de Cambissolos Flúvicos. As legendas originais do mapa de solos foram adaptadas aos objetivos dessa pesquisa e atualizadas segundo a nova Classificação Brasileira de Solos da Embrapa (1999). As novas legendas são listadas a seguir:

\section{Cambissolos Háplicos}

a) CXbd1- Cambissolos Háplicos distróficos típicos, textura argilosa e siltosa, A moderado, relevo suave ondulado.

b)CXbd2 - Cambissolos Háplicos Tb distróficos típicos, textura argilosa e muito argilosa, A moderado + Argissolos Vermelho-Amarelos distróficos típicos, Tb, textura média/argilosa e média/muito argilosa, A moderado, relevo montanhoso e forte ondulado. (Inclusão de Neossolos Litólicos distróficos típicos, textura média e argilosa, A moderado).

c)CXbd3 - Cambissolos Háplicos Tb distróficos típicos, textura argilosa e muito argilosa, A moderado + Argissolos Vermelho-Amarelos distróficos típicos, $\mathrm{Tb}$, textura média/argilosa e argilosa/muito argilosa, A moderado, relevo montanhoso e escarpado.

d)CXbd4 - Cambissolos Háplicos Tb distróficos típicos, textura argilosa pouco cascalhenta, A moderado e proeminente + Argissolos Vermelho-Amarelos distróficos típicos, $\mathrm{Tb}$, textura 
média/argilosa pouco cascalhenta, A moderado e proeminente, relevo montanhoso e forte ondulado.

e)CXbd5 - Cambissolos Háplicos Tb distróficos típicos, textura argilosa pouco cascalhenta, fase não pedregosa e pedregosa, A moderado e proeminente + Neossolos Litólicos distróficos típicos, textura argilosa e média pouco cascalhenta, fase pedregosa e não pedregosa, $\mathrm{A}$ proeminente e moderado, relevo montanhoso e escarpado. (Inclusão de Argissolos VermelhoAmarelos distróficos típicos, Tb, textura média pouco cascalhenta/argilosa pouco cascalhenta, A moderado e proeminente).

\section{Cambissolos Flúvicos}

a)CYbd1 - Cambissolos Flúvicos Tb distróficos gleissólicos, textura siltosa e argilosa, A moderado, relevo plano e suave ondulado + Gleissolos Háplicos $\mathrm{Tb}$ eutróficos e típicos, textura siltosa e argilosa, A moderado, relevo plano.

b)CYbd2 - Cambissolos Flúvicos Tb distróficos típicos, textura siltosa e argilosa, A moderado e proeminente, relevo suave ondulado e plano.

c)CYbd3 - Cambissolos Flúvicos Tb distróficos típicos, textura argilosa e média, A moderado e proeminente, relevo plano e suave ondulado.

d)CYbd4 - Cambissolos Flúvicos Tb distróficos típicos, textura argilosa e média, A moderado e proeminente, relevo suave ondulado e plano. 


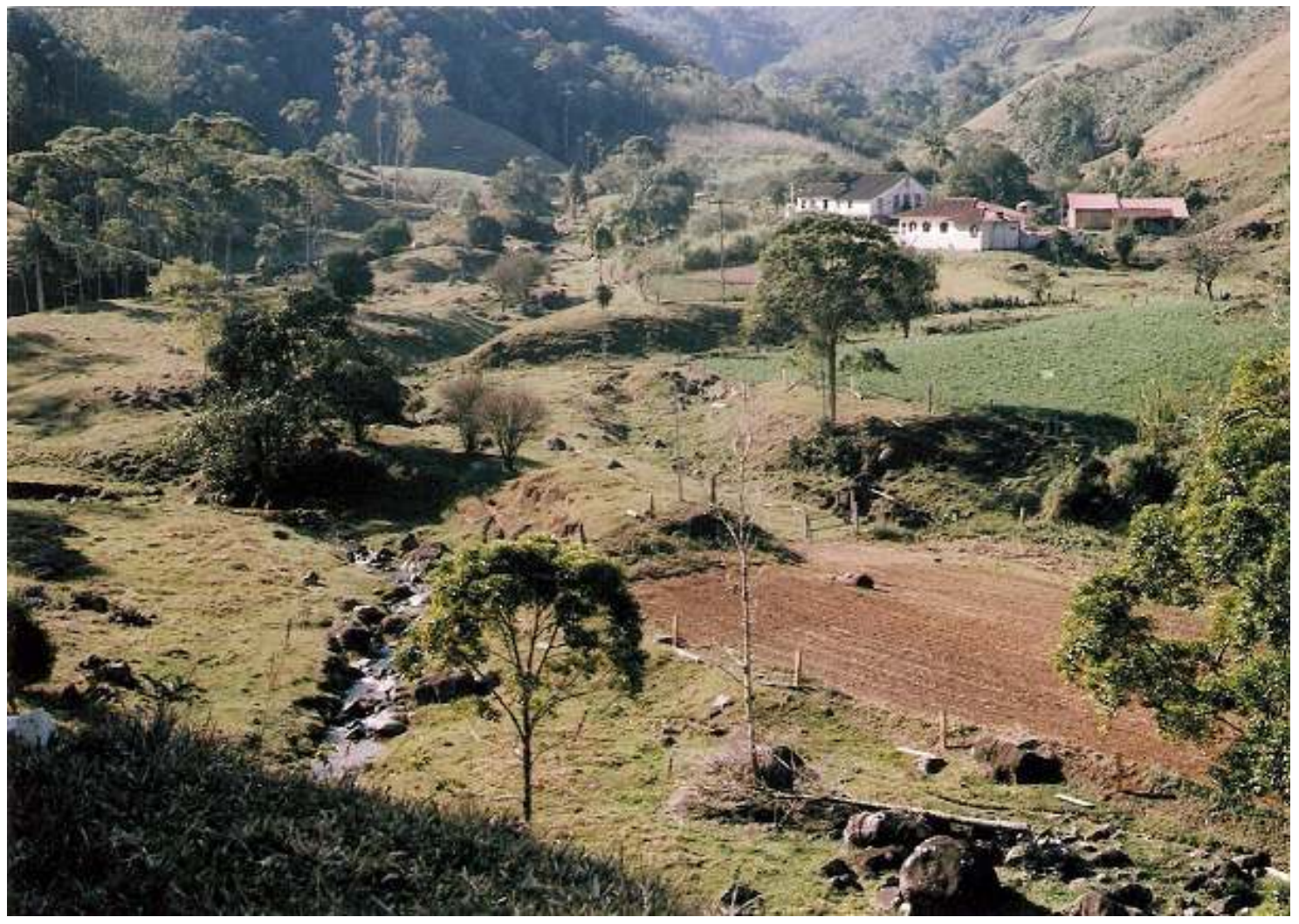

Figura 32 - Área de pastagens e hortaliças no vale do rio Braço do Norte, no município de Antônio Carlos - SC. ( Foto: Vicente R. Silva, julho/2006).

\section{Gleissolos}

Esses solos estão associados diretamente à influência do lençol freático alto, estando a maior parte do tempo saturados de água. São típicos de regiões de clima úmido e topografia plana e nas encostas imediatamente adjacentes aos rios ou nas depressões fechadas (Lepsch, 1982, p.99). A fertilidade natural é bastante variada, o que permite, na maioria das vezes, que sejam utilizados na agricultura, depois que o excesso de água é drenado por canais de drenagem (op. cit., p.101).

São solos mal drenados, ácidos pouco profundos e de textura argilosa dominantes. Em geral, apresentam condições hidromórficas propicias a ocorrência de oxidação ou de redução, devido a oscilações do lençol freático. Tais condições permitem a presença de mosqueados amarelos, avermelhados ou vermelhos, dentro do perfil (Vieira, 1988, p.422).

Moser (1990) descreve os solos Gleissolos como solos mediamente profundos, mal drenados e com permeabilidade muito baixa. A textura, é normalmente, argilosa nos 
horizontes subsuperficiais, podendo chegar a textura média no horizonte superficial. Sua utilização apresenta limitações, em função de riscos de inundações e drenagem restrita, devido a presença de lençol freático próximo a superfície. No entanto, podem ser utilizados em lavouras temporárias como o arroz de várzea, com bons resultados. Esses solos têm potencial para a exploração da terra com hortaliças (Moser, 1990, p.105).

Os gleissolos presentes na área de estudo situam-se no norte da bacia, nos vales dos rios Saudade e Três Riachos, na localidade de Limeira, no município de Biguaçu. Também ocorrem no baixo curso do rio Biguaçu (trecho retificado do canal). Esses solos são utilizados na lavoura temporária de arroz e hortaliças e em pastagens (Silva; Ross, 2006, p.5).

De acordo com o Gerco ( $3^{\mathrm{a}}$ fase), os gleissolos são desenvolvidos em várzea de relevo plano, margeando rios ou em locais de depressão e planície aluvionares sujeitas a inundações. Esses solos pertencem à unidade geomorfológica planície litorânea, formados por sedimentos do Holoceno e estão sob vegetação pioneira de influência fluvial. Sua principal limitação é a má drenagem, pois dificulta o manejo e o uso de implementos agrícolas (Shimizu; Vieira; Moser, 2003, p.586).

Foram plotadas no mapa de solos cerca de duas unidades de mapeamento, identificadas com as seguintes legendas:

\section{Gleissolos Melânicos}

a) GMbe - Gleissolos Melânicos Ta eutróficos chernossólicos, textura argilosa e siltosa + Gelissolos Háplicos Ta eutróficos típicos, textura argilosa e siltosa, A moderado, relevo plano.

\section{Gleissolos Háplicos}

a)GXve - Gleissolos Háplicos Ta eutróficos típicos, textura siltosa e média, A moderado, relevo plano.

Os Gleissolos melânicos ocorrem no vale dos rios Guiomar (município de Antônio Carlos), Saudades e Três Riachos (município de Biguaçu), todos tributários da margem esquerda do rio Biguaçu. Já os Gleissolos Háplicos estão presentes no baixo curso do rio Biguaçu e Três Riachos, em áreas de baixa declividade. No vale do rio da Guiomar (município de Antônio Carlos), e essa unidade de solos é utilizada com cultivo de hortaliças. 


\section{Neossolos Flúvicos}

São considerados solos pouco desenvolvidos, por serem jovens e estarem em fase inicial de formação. Os solos aluviais (neossolos) são desenvolvidos sobre sedimentos recentes, de origem fluvial, formandos por camadas alternadas e muitas vezes, por classes texturais distintas. São solos com grande importância agrícola, em muitas regiões do mundo, com destaque na produção de alimentos (Lepsch, 1982, p.110).

Os solos aluviais são pouco evoluídos, moderadamente a bem drenados, pouco profundos a profundos, argilosos, silte-argilosos ou textura média. A cor varia de amarelados ou acizentados, sem diferenciação aparente de horizontes (Vieira, 1988, p.433). Em geral não apresentam desenvolvimento de perfil e diferenciação de horizontes. Quanto a fertilidade natural pode ser baixa (distróficos) ou media a alta (eutróficos) (op. cit.).

Moser (1990) dá as seguintes características: solos minerais, não hidromórficos, pouco desenvolvidos e originados de sedimentos aluviais não consolidados. Predominam cores claras, embora possam ocorrer cores escuras intercaladas entre as camadas. Esses solos situam-se em áreas planas, em planície de inundação dos rios. As condições de má drenagem e as frequentes inundações podem limitar a utilização agrícola (Moser, 1990, p.106).

São formados por deposições fluviais do período Holoceno, sofrendo acréscimos de sedimentos por ocasião de inundações. Podem estar localizados nas calhas de drenagem, em áreas de topografia movimentada. Não é comum ter problemas de erosão, devido a situação topográfica, sendo favorável a mecanização agrícola (Shimizu; Vieira; Moser, 2003, p.658).

$\mathrm{Na}$ área de estudo ocorre apenas uma unidade de mapeamento, citada a seguir: Neossolos Flúvicos

a)RYbd1 -Neossolos Flúvicos Tb distróficos típicos, textura indiscriminada, A moderado + Cambissolos Flúvicos $\mathrm{Tb}$ distróficos e eutróficos típicos, textura siltosa e argilosa, A moderado, relevo plano e suave ondulado.

Na bacia do rio Biguaçu, situa-se ao norte no vale do rio Três Riachos em áreas de terras próximas ao rio, fazendo limite como a classe de solos Gleissolos Melânicos. Ocorre também, no baixo vale do rio Biguçu, na unidade geomorfológica Planície Fluvial. São solos utilizados com pastagens, hortaliças e plantio de grama para jardinagem. 


\section{Neossolos Quartzarênicos}

Segundo Vieira (1988), corresponde à classe de solos "areia quartzosa" hidromórficas, com característica de solos pouco evoluídos, submetidos a flutuação do lençol freático. As areias quartzosas marinhas são encontradas nas baixadas situadas em faixas ao longo do litoral (Vieira, 1988, p.410). Em outro trabalho, esse solo recebe a denominação de "areia quartzosa hidromórficas húmicas" que pertencem ao período Holoceno (Moser, 1990, p.106).

De acordo com a classificação do relevo presente no $3^{\circ}$ táxon, denominado de planície marinha/costeira. Esses solos são encontrados na faixa do litoral da cidade de Biguaçu, na praia de João Rosa ou Tamanco. Tratam-se de sedimentos areno-quartzosos, não consolidados, de origem marinha e depositados na faixa litorânea no período holoceno.

Em geral são solos profundos, com sequência de horizontes A e C. O horizonte A é pouco desenvolvido com baixos teores de matéria orgânica. No horizonte $\mathrm{C}$ predomina a coloração cinza claro a bruno-amarelo claro e textura de areia (quartzo hialino). São impróprios para uso agrícola, em função da baixa fertilidade natural, elevada acidez e má drenagem (Shimizu; Vieira; Moser, 2003, p.640).

Segundo o Gerco ( $3^{\text {a }}$ fase), ocorre na bacia uma unidade de mapeamento de Neossolos Quartzarênicos:

a)-RQo - Neossolos Quartzarênicos Órticos típicos, A moderado + Neossolos Quartzarênicos hidromórficos típicos, A proeminente e moderado, relevo plano (vide mapa de solos).

Também são encontrados na área urbana de Biguaçu solos de mangues, sendo denominados pelo IBGE, de tipos de terrenos. Lepsch (1982) denomina solos salinos ou halomórficos, como sendo solos que apresentam concentração muito alta de sais solúveis. Ocorrem em áreas próximas ao mar, sofrendo a influência da adição de água do mar, nas zonas mais baixas e inundáveis pela maré alta (Lepsch, 1982, p.105).

Moser (1990) apresenta como um tipo de solo, denominado de "Solos Indiscriminados de Mangue”. O autor diz que são solos predominante halomórficos, alagados, ocorrendo nas partes baixas do litoral, próximo a foz de rios, influenciado pelo ritmo das marés (Moser, 1990, p.107). 
Lúcio Vieira (1988) define o mesmo nome como "solos indiscriminados de mangue" e os caracteriza por sedimentos inconsolidados, recentes, geralmente gleizados, formados por sedimentos misturados a materiais orgânicos, oriundos da decomposição de detritos de mangue e de atividade biológica (Vieira, 1988, p.434). A vegetação típica desses solos é o manguezal.

A diferenciação de horizontes é pouco nítida, a textura é indiscriminada, relacionada a relevo plano, por vezes, côncavos. São solos sem vocação agrícola, por apresentarem grandes limitações, como excesso de água, elevados teores de sais, inundações marinhas diárias. Trata-se de um ecossistema essencial e frágil, sendo considerado área de preservação permanente, de acordo com a legislação ambiental (Shimizu; Vieira; Moser, 2003, p.668).

Na planície marinha de Biguaçu existia um manguezal, no rio Caveiras (integrante da bacia do rio Biguaçu), que foi destruído por desmatamentos, aterros, ocupação humana e retificações do canal do rio. O manguezal do rio Biguaçu possui área maior na margem esquerda do rio, próximo a desembocadura na baía norte. A ação humana tem promovido sua redução com desmatamentos, aterros para a construção de casas, lixo, poluição por resíduos de agrotóxicos (plantio de hortaliças e grama a montante). A legenda usada no mapa de solos é SM - Solos Indiscriminados de Mangue.

\subsubsection{1-Mapa de Solos}

O cambissolos é a classe de solos dominante na bacia do rio Biguaçu, ocupando grandes áreas na porção central e oeste. Esses solos podem variar de rasos a profundos, tanto quanto o relevo, de plano a montanhoso. Os cambissolos estão presentes na unidade de relevo Planalto de Biguaçu/Três Riachos e em parte do Planalto de Cimeira. Em termos do mapa geológico, corresponde aos domínios do Complexo Metamórfico-Migmático (pEcd e pEcmt). Os cambissolos ocorrem na Serra de Santa Filomena (ao sul) e Serra do Pai João. Outra região é na Serra das Congonhas e Serra do Macaco Branco, porém sob domínios geológico da Suíte Intrusiva Valsungana (Planalto de Cimeira).

Os argissolos-vermelho-amarelos têm sua principal área de ocorrência a nordeste da bacia, próximo ao litoral. Apresentam uma área menor na porção noroeste da bacia, dentro do Planalto de Cimeira, pertencente aos domínios da Suíte Intrusiva Valsungana. Os cambissolos flúvicos possuem grande áreas nas planícies dos rios Biguaçu e Três Riachos. 
Os gleissolos são os solos típicos no vale do rio da Guiomar (município de Antônio Carlos). Já os rios Saudade, Três Riachos e Biguaçu integram o município de Biguaçu.

Os neossolos flúvicos estão presentes em trechos do vale do rio Três Riachos, no município de Biguaçu. Esses solos correspondem ao ambiente do modelado de sedimentação, ou seja, ao quaternário fluvial (Qf), no mapa geológico e a planície fluvial (iv) no mapa de unidades de relevo.

Na porção leste da bacia temos a classe de solos neossolos quartzarênicos (RQo), na área de influência da foz dos rios Biguaçu e Caveiras. No mapa geológico é representado pelo quaternário marinho $(\mathrm{Qm})$. No mapa de unidade de relevo é denominado de planície marinha de Biguaçu, no litoral central de Santa Catarina. 


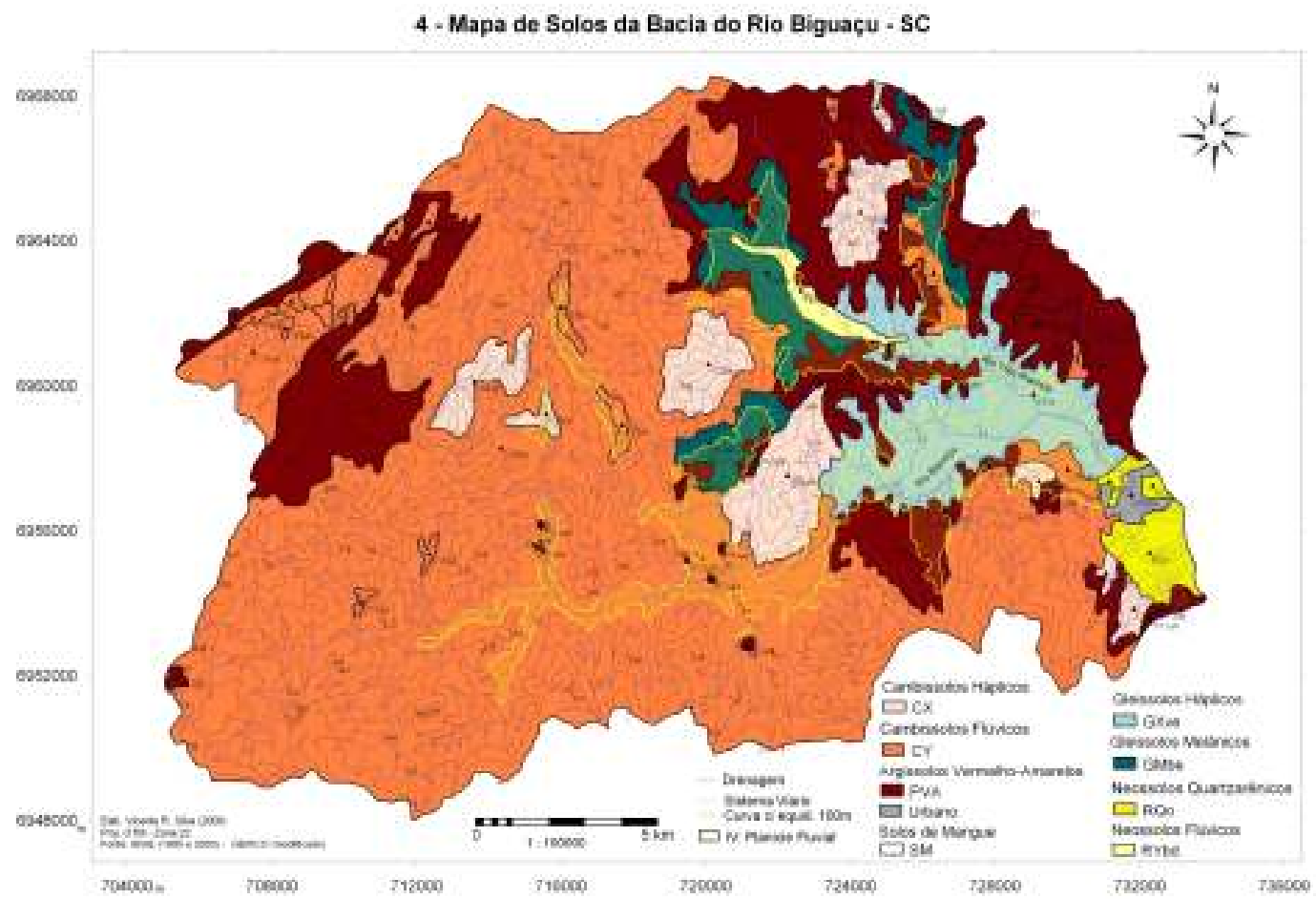

Figura 33 - Mapa de solos da bacia do Rio Biguaçu-SC. 


\subsection{6-Características da vegetação}

Podemos conceituar vegetação como: "conjunto de plantas que são dependentes de seu ambiente e se influenciam mutuamente, inclusive modificando seu próprio ambiente" (Glossário de Ecologia, 1997, p.247-248). A grande variedade de tipos de relevo (planície, planaltos e serras) derivada da grande diversidade de formações geológica e da atuação dos processos morfogenéticos, imprime na paisagem uma forte influência na compartimentação do clima e da vegetação na região sul do Brasil (Leite; Klein, 1990, p.113).

Segundo esses autores, cerca de $60 \%$ da cobertura vegetal eram de florestas e $40 \%$ de outros tipos (formações campestres e pioneiras). $\mathrm{Na}$ bacia do rio Biguaçu, a vegetação florestal é constituída pelas seguintes regiões fitogeográficas: Região da Floresta Ombrófila Densa (Floresta Atlântica); Floresta Ombrófila Mista (Floresta de Araucária); Formações Pioneiras Fluvio-Marinhas (manguezal). Também ocorre em pequenas áreas de campos de altitude, na porção oeste da bacia.

De acordo com a Classificação da Vegetação Brasileira que é baseada no sistema fisionômico-ecológico, a Floresta Ombrófila Densa (Floresta Pluvial Tropical), foi dividida em cinco formações distintas, ordenadas segundo uma hierarquia topográfica, com diferenças fisionômicas, de acordo com as faixas de altitude. As formações são: Formação Aluvial; Formação de Terras Baixas; Formação Submontana, Formação Montana e Formação AltoMontana (Veloso; Rangel Filho; Lima, 1991, p.64). Dentre essas, só não ocorre na área de estudo, o tipo Formação Alto-Montana.

A vegetação primária do território catarinense é denominada por Klein (1978, p.1,6), como Floresta Pluvial de Encosta Atlântica. O autor classifica o trecho do litoral da bacia do rio Biguaçu, como: floresta tropical do litoral e encosta centro-sul. Essa região possui matas de encostas íngremes, com árvores de troncos tortuosos, relativamente baixos e encimados por copas largas. Apresenta composição complexa, tendo em vista, a grande variedade de solo e de microclimas.

Na Formação Aluvial não ocorre variação topográfica. É típica das planícies fluviais (terraços fluviais). O segundo tipo Formação de Terras Baixas está situado entre $24^{\circ}$ a $32^{\circ}$ de latitude Sul, variando de 5 metros até 30 metros. O terceiro tipo, Formação Submontana, situa-se na faixa de $24^{\circ}$ a $32^{\circ}$ de latitude Sul, em altitudes de 30 metros até 400 metros, sendo 
encontrada nas encostas dos planaltos e serras. O quarto tipo, Formação Montana, localiza-se no alto dos planaltos e/ou serras, na faixa de $24^{\circ}$ até $32^{\circ}$ de latitude Sul. A altitude varia de 400 metros até 1.000 metros (Veloso; Rangel Filho; Lima, 1991, p.64-65).

\section{Floresta Ombrófila Densa e Formações}

Floresta Ombrófila Densa Aluvial - É a formação ribeirinha (floresta ciliar), que ocorre ao longo de rios, ocupando os terraços antigos da planície quaternária. A palmeira está presente no estrato dominante e na submata. Apresenta grande número de lianas lenhosas e herbáceas. As epífitas são abundantes, porém com poucos parasitas (Veloso; Rangel Filho; Lima, 1991, p.65).

Floresta Ombrófila Densa de Terras Baixas - Essa formação é típica dos terraços fluviais de origem quaternária. Em geral, as planícies são formadas pelo assoreamento, devido a erosão atuante nas serras costeiras e nas enseadas marítimas.

Floresta Ombrófila Densa Submontana - De acordo com os autores (op.cit.), as áreas de dissecamento do relevo em planaltos e serras, apresentam solos medianamente profundos. Essa formação florestal possui plantas lenhosas (com gemas situadas a mais de $50 \mathrm{~cm}$ de altura e que não morrem a cada ano), com alturas uniformes. As plântulas estão na submata e há presença de palmeiras de pequeno porte e lianas herbáceas.

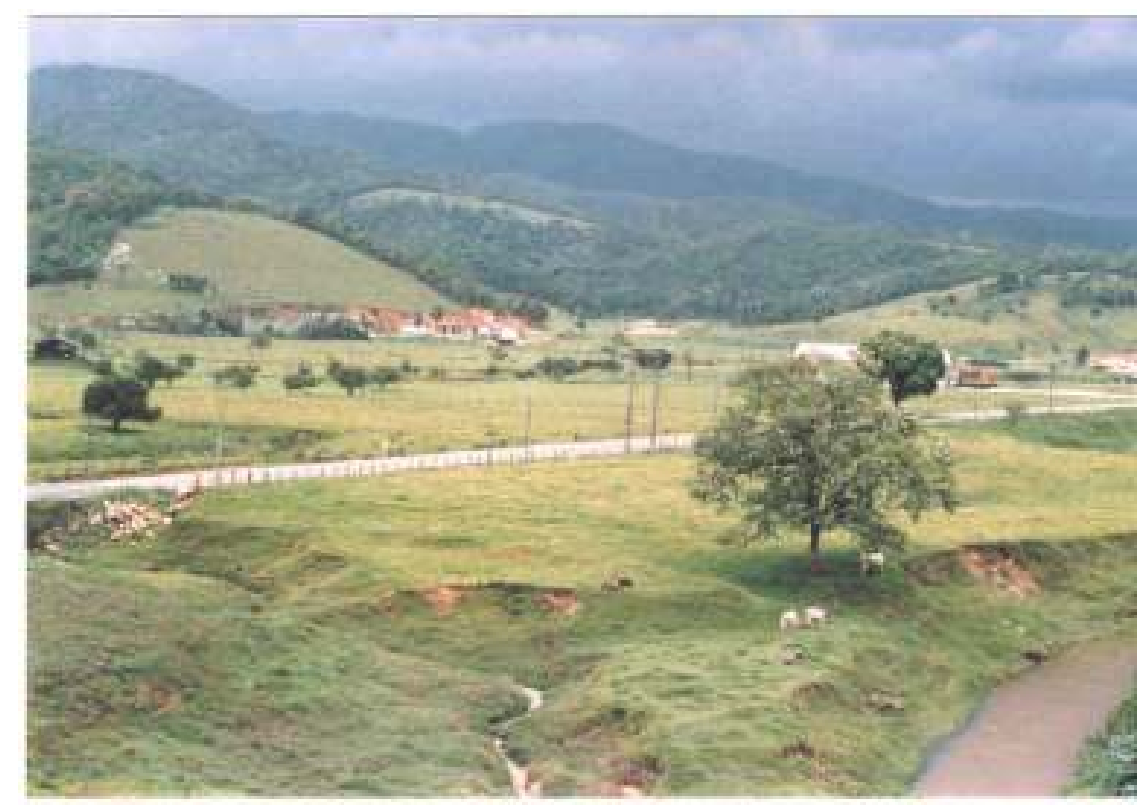

Figura 34 - Vale do rio Biguaçu, próximo à cidade de Antônio Carlos-SC. Aspecto do uso da terra com pastagens e ausência de mata ciliar. Ao fundo, vegetação secundária nas encostas dos morros. (Foto Edison Fortes,fevereiro/ 2005). 
Floresta Ombrófila Densa Montana - A estrutura dessa formação é mantida até próximo ao topo dos relevos mais dissecados. Os solos são pouco desenvolvidos, sendo delgados ou litólicos, o que influência no tamanho das árvores. O dossel é uniforme (20 metros), onde as populações vegetais possuem indivíduos finos, casca grossa e rugosa, folhas miúdas e de consistência coriácea (Veloso; Rangel Filho; Lima, 1991, p.67).

A Floresta Ombrófila Densa apresenta estratos superiores com árvores variando de 25 a 30 metros de altura. Tem característica "perenifoliadas e densamente dispostas com a presença de brotos foliares desprovidos de proteção contra a seca e as baixas temperaturas" (Leite; Klein, 1990, p.118). É considerada na Região Sul do Brasil, a classe de formação mais pujante, heterogênea e complexa, sendo capaz de produzir de forma natural grandes volumes de biomassa, em curto e médio prazos. Grande número de espécies são heliófitas que competem na busca pela ocupação do espaço no dossel da floresta. Essas características favorecem a criação de ambientes favoráveis à instalação de diferentes formas de vida, nos estratos inferiores, no interior da floresta. Segundo os autores (op. cit.), os ambientes de maior desenvolvimento da Floresta Ombrófila Densa estão entre os 30 metros e 1.000 metros de altitude, correspondendo as formações submontanas e montanas.

Apesar da grande diversidade de espécies e de formas de vida presentes em suas formações, porém somente há um reduzido número de espécies arbóreas que se destacam na fisionomia, compondo entre $70 \%$ e $80 \%$ da cobertura superior (Leite; Klein, 1990, p.119). Fatores de ordem ambiental, que influenciam na diversidade ecológica, fazem com que algumas espécies passem a ser dominantes, assumindo o predomínio fisionômico da formação em detrimento de outras menos adaptados.

\section{Floresta Ombrófila Mista (Floresta de Araucária)}

A Araucária do Brasil, cujo nome científico é Araucaria angustifolia (Bertoloni) O. Ktse, foi descrita primeiramente por Bertoloni, em 1819. Essa floresta pode ser concebida pela mistura de floras de diferentes origens, com a definição de padrões fisionômicos típicos, em zona climática marcadamente pluvial (Leite; Klein, 1990, p.121). A vegetação da região dos pinhais não apresenta uma formação homogênea e contínua, porém é constituída por vários tipos de submatas. Outras vezes, os pinhais dão espaço aos campos ou capões arbustivos (Klein, 1978, p.10). 
De formação essencialmente de ambiente temperado e heliófita, a araucária apresenta atualmente condições desfavoráveis, tanto pela incompatibilidade com o clima atual e pela destruição da espécies pela ação humana Klein (1960) apud Leite; Klein (1990, p.123). A Floresta de pinheiros é típica do planalto meridional do Brasil, onde é considerado seu atual 'clímax climático'(Veloso; Rangel Filho; Lima, 1991, p.71). A Floresta Ombrófila Mista estava presente nas altitudes superiores a 800 metros, as áreas mais representativas da formação alto-montana. No passado, a floresta de Araucária abrangia grandes regiões do planalto catarinense.

No litoral, penetrava até o limite do vale do rio Itajaí, onde se tornava ausente. Em geral, as araucárias ficam afastadas do litoral, sendo difundida pelos habitantes do estados sulistas, a seguinte frase: "o pinheiro não quer ver o mar" (Hueck, 1953, p.717). Para o botânico citado, os campos da região sul do Brasil seriam restos de uma paisagem antiga e em vias de desaparecimento. Em sua longa evolução, a araucária procurava avançar sobres as áreas de campos. No entanto, no embate com a mata atlântica, a floresta de araucária perdia espaço. Isso ocorre, porque as plantas novas da araucárias precisam germinar com uma certa intensidade de luz, frente a concorrência das espécies da floresta úmida (Hueck, 1953, p.720). As espécies de araucárias, em geral, variam de 25 a 30 metros de altura, sendo que o tamanho destes, decresce da periferia para o centro, bem como a curvatura da copa (Romariz, 1996, p.15).

Normalmente a araucária aparecia associada a outras espécies como a: imbuia, canela, erva-mate, sassafrás, jacarandá, caviúna, camboim, bragatinga, paineira, manjoleiro, cedro rosa, guabiroba da serra, pinheiro bravo, pau marfim e aroeira. A araucária é um conífera da família das Araucariáceas. Na estrutura de sua mata, apresentava dois estratos arbóreos e um arbustivo. No estrato superior, o pinheiro. No estrato inferior, tinha outras espécies de 4 a 6 metros, variando de acordo com as condições locais e o estágio da vegetação. Dora Romariz (1996) denomina essa formação de Floresta aciculifoliada - Pinheiral, que no estrato arbóreo predominava a imbuia, a erva-mate e várias espécies de canela, em Santa Catarina e Paraná (Romariz, 1996, p.16).

Em relação aos solos, não apresentavam limitações a sua ocupação, com exceção de solos muito úmidos. Em Santa Catarina, a região ocupada pela Floresta Ombrófila Mista foi explorada intensamente sua madeira, levando quase ao seu extermínio. Hoje as antigas áreas 
dos pinheiros são usadas com pastagens e em lavouras anuais. Uma das características marcantes dessa formação era a sua fisionomia na paisagem, onde era nítida a separação dos campos das áreas de pinheiros. O estado de Santa Catarina possui cinco tipos de sucessão, araucária e campo; araucária e canela lageana; araucária e mata pluvial; araucária e imbuia; araucária e sucessões pioneiras (Haymussi, 1993, p.5).

A araucária é uma espécie pioneira, sendo muito apropriada para o reflorestamento em campo aberto. Por se tratar de uma excelente madeira era utilizada na fabricação de caixas, móveis, vigamentos, tábuas para construção de casas, compensados, celulose, papel etc. A fase mais evoluída da Floresta Ombrófila Mista é aquela associada com imbuia, de ocorrência maior em Santa Catarina e no Paraná. Uma das maiores reservas da Floresta de Araucária, localiza-se em Caçador-SC, no meio oeste catarinense. A reserva com 1.200 hectares foi tombada pelo governo federal na década de 1940, e hoje pertence a Embrapa (Haymussi, 1993, p.5).

\section{Floresta Ombrófila Mista Montana}

Essa formação ocorre no planalto, em altitudes acima de 500 metros. As grandes áreas dessa floresta foram substituídas por uso da terra com agricultura e pecuária extensiva. Atualmente, a formação só ocorre em pequenas áreas de remanescentes, sem expressão econômica (Veloso; Rangel Filho; Lima, 1991, p.72-73).

\section{Campos de Altitude}

Nas áreas do planalto de cimeira da bacia do rio Biguaçu, podemos encontrar áreas isoladas e delimitadas por campos de altitudes. Rizzini (1979), denominadas de campo brejoso, sendo tratos baixos e alagadiços densamente povoados de gramíneas, ciperáceas e algumas ervas hidrófilas (...)(Rizzini, 1979, p.203). Esse campos de altitude possuem solos rasos e são ocupados por vegetação gramíneo-lenhosa e pequenas turfeiras (Leite; Klein, 1990, p.120).

Segundo Klein (1978), que cita ao ocorrência de campos de altitude na borda oriental do planalto catarinense, na região da cristas da Serra Geral e Serra do Mar, são encontrados manchas de campos, com o predomínio do capim-caninha (Andropogon lateralis), nas partes mais secas e nas mais úmidas ocorre as tiriricas do genêro Rhynchospora e Scleria (...). O autor, também assinala a presença de turfeiras formadas por musgos e samambaia-dos- 
banhados (Blechnum imperiale). As gramíneas mais frequentes nos campos são: Andropogon macrothryx, Agrostis montevidensis, Arundinaria ulei, Agrostis ramboi e etc (Klein, 1978, p.19).

\section{A vegetação da bacia do rio Biguaçu}

De acordo com a Classificação da Vegetação Brasileira (Veloso; Rangel Filho; Lima, 1991), ocorriam na bacia do rio Biguaçu, três regiões fotoecológicas: região da floresta ombrófila densa; região da floresta ombrófila mista; estepes (campos gerais planálticos estepe gramíneo-lenhosa (campo limpo) e sistema edáfico da primeira ocupação (formações pioneiras) -Vegetação com influência fluviomarinha (manguezal).

A principal cobertura vegetal da bacia do rio Biguaçu é representada pela Floresta Ombrófila Densa, que apresenta quatro tipos, conforme hierarquia topográfica, a saber: formação aluvial, formação de terras baixas, formação submontana e formação montana.

As formações aluvial e de terras baixas foram praticamente exterminadas pela ação humana pelo extração da madeira, só restando pequenos fragmentos florestais, já bastante alterados pelo corte seletivo. Houve a substituição da cobertura vegetal original pelo uso em agricultura e pecuária semi-extensiva. Predominam fragmentos florestais com espécies típicas de floresta secundária.

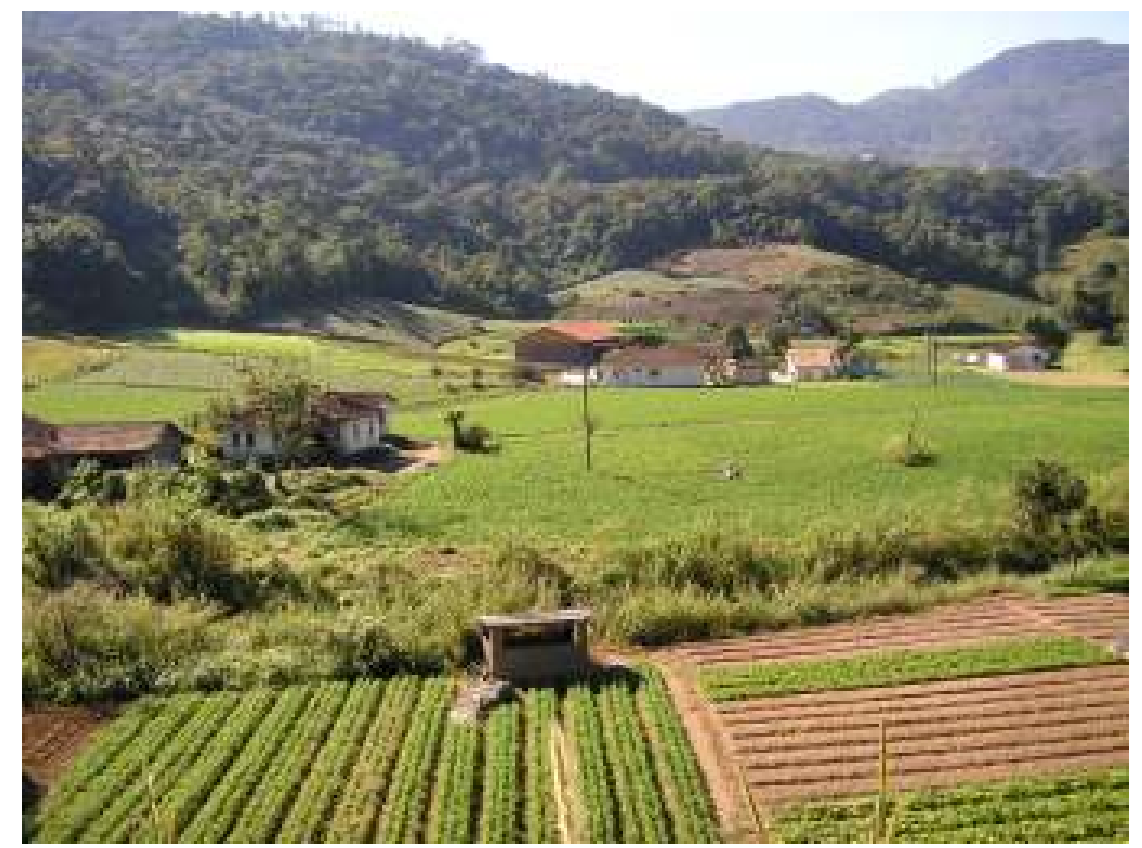

Figura 35 - Vale do rio Rachadel com hortaliças e vegetação secundária nos morros, na localidade Vila Doze de Outubro, município de Antônio Carlos-SC. (Foto Edison Fortes julho/2005). 
Floresta Ombrófila Densa - formação densa fluvial e terras baixas. Dada a condições de relevo plano, a floresta aluvial acha-se atualmente descaraterizada pelas atividades humanas. São áreas utilizadas com pastagens semi-extensivas para gado bovino. Na agricultura predomina o uso com lavouras temporárias (hortaliças), e plantio de grama para jardins. Em áreas limitadas da formação de terras baixas, com relevo plano, a vegetação primária foi suprimida para o cultivo de lavouras e posteriormente abandonada, contribuindo para o surgimento de vegetação secundária de origem antrópica (Coura Neto, 1997, p.8).

Em termos mais gerais, predomina no visual, a paisagem com vegetação secundária nas áreas onde houve intervenção humana, destinadas a mineração, agricultura ou pecuária. A floresta ombrófila densa submontana, encontra-se sob substrato de rochas do Pré-cambriano. Os solos dominantes são os cambissolos e argissolos, confome o mapa de solos da bacia do rio Biguaçu, figura 33. Em estado natural essa formação possuia árvores de grande porte e densa presença de epífitas, bromeliáceas e lianas.

$\mathrm{Na}$ área de estudo, as atividades econômicas teveram início a partir de 1830, por parte de colonos açoreanos e alemães, com profundas transformações na paisagem. $\mathrm{O}$ avanço do homem sobre a vegetação primária, cedeu espaço a culturas cíclicas, pastagens e pequenos reflorestamentos (talhões), principalmente de eucalipto (Eucalyptus ssp.). Após o abandono, muitas áreas deram lugar ao surgimento de vegetação secundária em diversos estágios evolutivos, sendo agrupados sob a denominação de capoeirinha, capoeira e capoeirão (Coura Neto, 1997, p.8). No mapa de ocupação e uso da terra 2006, estão delimitados os fragmentos florestais (forma de polígonos).

$\mathrm{Na}$ vegetação secundária, podemos listar algumas espécies arbóreas: jacatirão-açu (Miconia cinnamofolia), pau-jacaré ( Piptadenia rigida), caxeta (Psychotria longipes), mangue-formiga (Clusia criuva), maria-mole (Guapira opposita), tanheiro (Alchornea triplinervia) e a expressiva ocorrência de guarapuvu (Schizolobium parahyba) (...) (Coura Neto, 1997, p.8).

Na formação montana que ocorre em altitudes que variam de 400 a 1.000 metros, na porção extremo oeste da bacia do rio Biguaçu. O tipo de solo mais comum é o cambissolos. Fragmentos florestais dessa formação são encontrados em áreas de relevo com declividade acentuada, que dificultou o desmatamento generalizado. Contudo, nas áreas mais baixas e de 
relevo menos movimentado, houve a substituição da vegetação original por lavouras temporárias e permanentes, pastagens e talões de reflorestamentos de eucaliptos (Coura Neto, 1997, p.9). Na zona de Biguaçu [área litorânea da cidade], a mata representava 46,78\% da área, concentrando-se no maciço de São Miguel. A classe de pastagens/capoeirinha corresponde a $27 \%$ da área nas vertentes dos modelados e nas planícies (Mendonça, 2002, p.91).

\section{Floresta Ombrófila Mista}

$\mathrm{Na}$ área de estudo só ocorre a formação montana, em altitudes acima de 500 metros, no extremo oeste da bacia, no município de Antônio Carlos. Devido a inserções humanas, restaram poucos remanescentes da floresta de pinheiros. Essa formação só ocorre no município de Antônio Carlos, nos altos cursos dos rios Farias e Rachadel, na região do Planalto de Cimeira, conforme o mapa de unidades do relevo, figura ---.

No mapa de cobertura e uso da terra 2006, não foi possível detalhar a cobertura vegetal, em função da escala do mapa (1: 50.000). A legenda é mais genérica, onde só foi possível diferenciar capoeirões e capoeiras e capoeirinhas. Na formação montana há poucos relictos de Araucaria angustifolia, que, em geral, ocorriam dentro da floresta ombrófila densa. Vegetação de influência fluviomarinha (manguezal)

O manguezal possui solos lodosos com elevado teor salino e baixa oxigenação. A siriúba (Avicennia schaureriana) é a espécie dominante. Esta formação localiza-se no município de Biguaçu, próximo à foz do rio Biguaçu. $\mathrm{O}$ manguezal aparece recobrindo sedimentos arenosos do quaternário. O aspecto fisionômico é herbácea ou arbustiva, influenciadas pelo oceano. O ambiente vasoso é encontrado em baías e desembocadura de rios (Klein, 1978, p.2). 


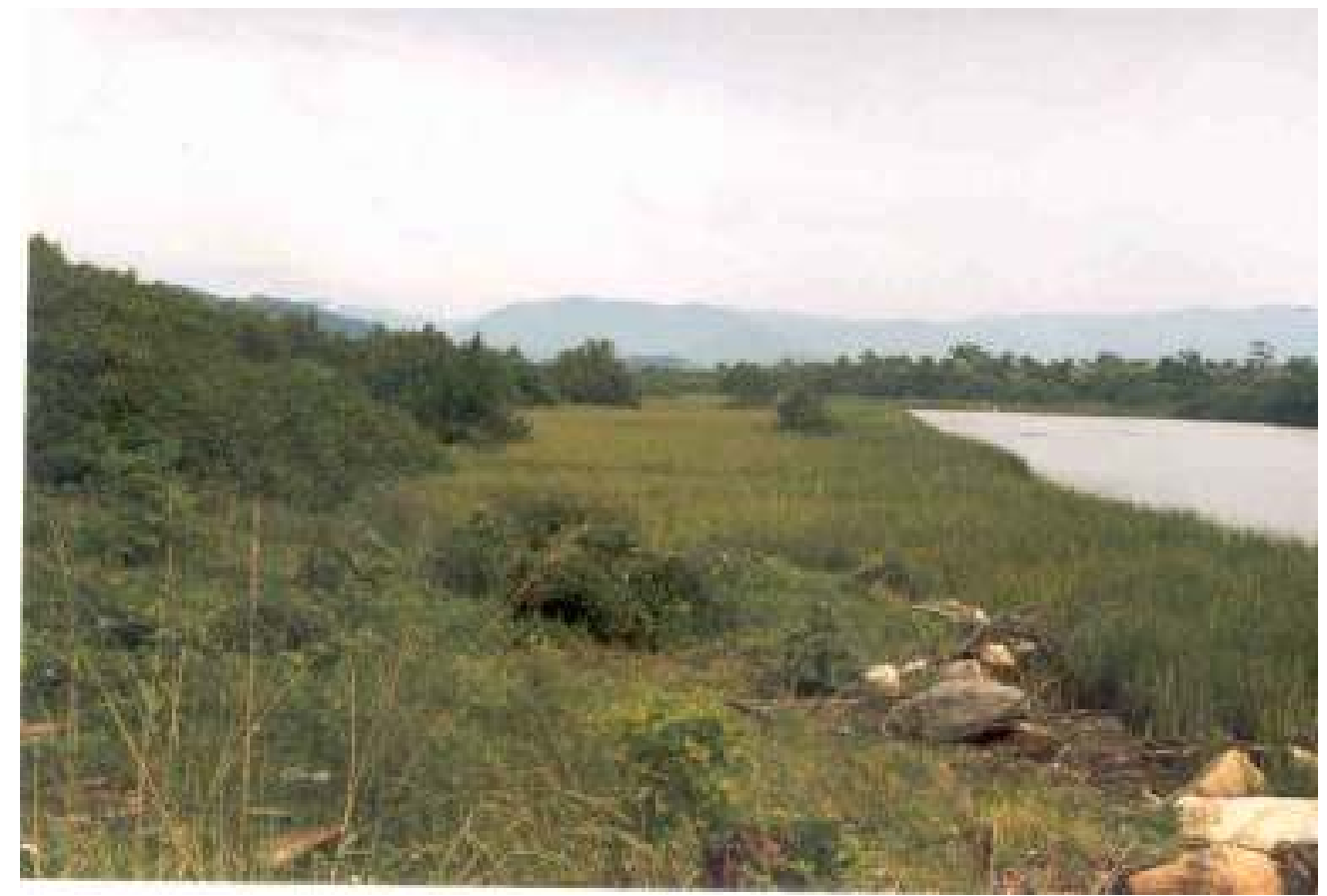

Figura 36 - Aspecto do manguezal junto à foz do rio Biguaçu na zona urbana de Biguaçu - SC. (Foto Edison Fortes, fevereiro/ 2005).

$\mathrm{Na}$ área urbana do distrito-sede de Biguaçu existia outro manguezal no rio Caveiras, que integra a bacia hidrográfica do rio Biguaçu. Desde 1978, a localidade de rio Caveiras era utilizada para empreendimentos imobiliários. Estima-se que o local recebeu aproximadamente dois metros de aterro. Conforme estudo realizado por Panitz; Porto Filho em 1992, o manguezal tinha área original de $120.000 \mathrm{~m}^{2}$ e tinha restado apenas $3.000 \mathrm{~m}^{2}$. Desde 1979 , uma imobiliária obteve a autorização da Prefeitura Municipal de Biguaçu para lotear o local, com a abertura da Av. Beira Rio e que permitiu a invasão por população de baixa renda. Em 1988 outra imobiliária comprou o terreno e em 1989 concluiu os trabalhos, realizando desmatamentos, aterros e terraplanagem, com a venda de lotes (Panitz; Porto Filho, 1993, p.93). No laudo pericial elaborado pela bióloga Clarice Panitz, em 1992, concluiu-se que 98\% da área aterrada era ambiente de planície de maré, ou seja, manguezais e marismas. Segundo os autores (op. cit.), devido ao grande número de tensores que atuaram no local (desmatamentos, aterros, canalizações e retificação), pelo tempo de sua ação e efeitos residuais desses tensores, a recuperação natural ou artificial do manguezal seria impossível e economicamente inviável.

Segundo estudos realizados para a perícia ambiental, ocorreram grandes prejuízos ambientais (perda de produtividade biológica, destruição do ecossistema), sociais (instalação 
de condições sanitárias precárias) e perda de subsídios complementares da dieta alimentar. Após a intervenção antrópica, o local estava em estágio adiantado de colonização, com vegetação típica de transição. De acordo com Porto Filho (1994, p.69), o rio Caveiras, que no passado sustentava um manguezal, encontra-se totalmente assoreado e entulhado.

Atualmente, no local está instalado o bairro Saveiro que é considerado uma das comunidades mais carentes do município de Biguaçu. Em trabalhos de campo no local, verifica-se a total ausência de vegetação de transição e a grande quantidade de moradias precárias nas áreas marginais do rio Caveiras.

No manguezal do rio Biguaçu os principais tensores são desmatamentos, aterros, retificação do rio Biguaçu a montante da ponte sobre a BR-101, sedimentação intensa da foz do rio Biguaçu, lixo sólido, poluição de esgotos domésticos etc. Recentemente foram lançadas pela Prefeitura Municipal de Biguaçu (outubro de 2006), as obras do projeto Beira-Rio Habitar Brasil/BID. Foi escolhida a área da foz do rio Biguaçu, em virtude de estar sofrendo um intenso processo de ocupação desordenado, desde 1984 e de intensa degradação ambiental. O projeto prevê a instalação de infra-estrutura urbana e social, visando retirar casas que estão em área de preservação permanente (APP). Deverão ser retiradas moradias em áreas de manguezal, recuperação de áreas degradadas, drenagem pluvial, rede coletora de esgoto, sistema de tratamento de esgoto, abastecimento de água, iluminação pública e pavimentação (PMB, 06/10/06, 2006).

O fragmento do manguezal do rio Biguaçu foi cartografado no mapa de ocupação e uso da terra 2006 e no mapa de legislação ambiental da bacia do rio Biguaçu figura 13 e 42 . Na margem esquerda do rio Biguaçu, o manguezal possui maior área e possivelmente está menos alterado. Na margem direita, essa vegetação sofre descaraterização por ocupação humana. 


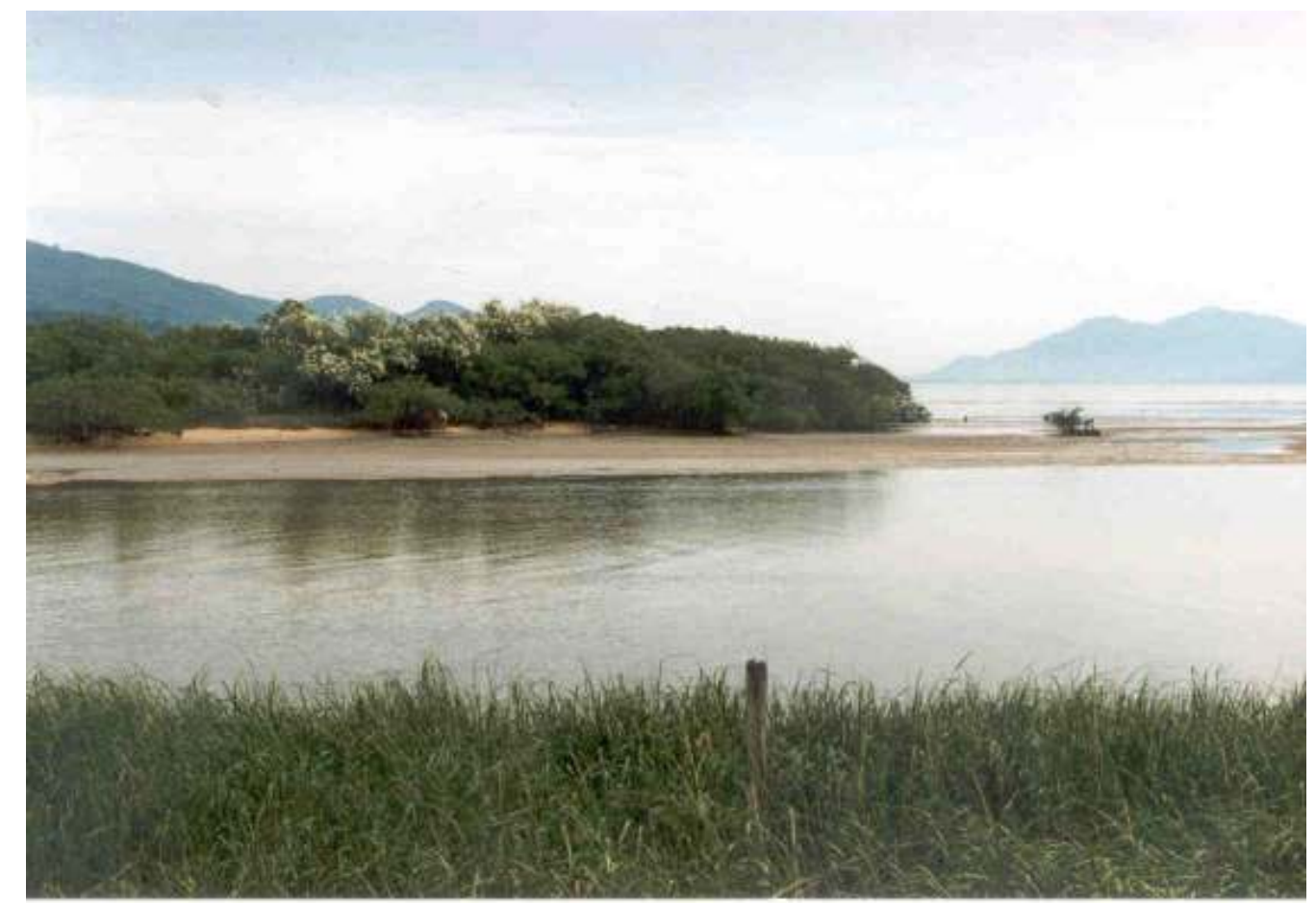

Figura 37 - Área da foz do rio Biguaçu, vista da barra de desembocadura. Na margem esquerda, vegetação de manguezal. (Foto Edison Fortes, fevereiro/2005).

Uma das maiores ameaças ao manguezal é a urbanização acelerada da faixa litorânea, com a proliferação de loteamentos irregulares e dos balneários (Leite; Klein, 1990, p.143).

\section{Campos de altitude}

Ocorre de forma esparsa e de dimensões reduzidas no Planalto de Cimeira da bacia do rio Biguaçu. Em função da escala do mapa de ocupação e uso da terra atual (1: 50 .000), não foram cartografados. 


\section{7-Fragilidade Ambiental}

\section{1-Mapa de Fragilidade Ambiental}

Para a realização de estudos integrados na bacia é necessária a compreensão da dinâmica de funcionamento do ambiente natural e de intervenções humanas. A funcionalidade dos ambientes naturais e aqueles modificados pelo homem, e com base na visão sistêmica da geografia. É através ação combinada da energia solar, representada pela atmosfera e da energia do interior da Terra, por meio da litosfera, essa troca permanente de energia e matéria entre os componentes da natureza é responsável pela existência da vida na Terra.

Grigoriev (1968), concebeu o “estrato geográfico da terra”, que dá suporte para que os seres humanos tenham um carácter social e biológico (Ross, 1994, p.64). O grau de alterações nos diferentes componentes da natureza possui cada vez mais intensidade e complexidade, devido aos avanços tecnológicos. Com isso, acentua-se o grau de modificações na funcionalidade, promovendo graves processos degenerativos ao ambiente natural.

Segundo Ross (1994), o conhecimento das potencialidades dos recursos naturais, depende de levantamentos de minerais e rochas, relevo, solo, clima, das águas e da vegetação. Assim sendo, deve incluir todos os componentes do "estrato geográfico da terra”. Para a análise da fragilidade dos elementos da natureza, devem ser avaliados de forma integrada, quando pretende-se aplicá-la ao planejamento territorial ambiental, baseado no conceito de unidade ecodinâmica Tricart (1977) apud Ross (1994, p.65). Essa concepção de Tricart (1977), é de base ecológica e está de acordo com a Teoria Geral dos Sistemas, que entende que na natureza, as trocas de energia e matéria estão relacionadas às relações de equilíbrio dinâmico.

Para a análise de fragilidade dos ambientes naturais, deve ser precedida por estudos básicos de litogia, de relevo, de clima, de solos e de uso da terra. No produto final são gerados os mapas temáticos. Para elaborar o mapa de fragilidade ambiental da bacia do rio Biguaçu, foram obtidas informações espaciais do mapa clinográfico, do mapa de unidades do relevo e do mapa de solos.

As classes de declividade que deram suporte à elaboração das categorias hierárquicas, propostas por Ross (1994), por exemplo, a classe muito fraca até 6\%, não aparecem em 
destaque no mapa, pois são as áreas de planície fluviais e planície marinha, com relação a fragilidade a erosão. Com relação aos solos a classe de fragilidade é do tipo forte (4), formada pelos solos argissolos e cambissolos. No tipo muito forte (5), temos os neossolos quartzarênicos e os neossolos flúvicos. Os gleissolos que ocorrem nas planície fluviais não foram contemplados nessa classificação, elaborada por Ross (1994).

Na fragilidade à erosão, foram demarcadas áreas no mapa em três categorias: média (3), forte(4) e muito forte (5). Em termos de área territorial, predomina o tipo muito forte com declividade acima de 30\%. A segunda categoria em área de abrangência seria a média, com declividade variando entre 12 e $20 \%$. E por último, o tipo forte, presente em pequenas áreas pontuais. No mapa de unidade de relevo, as áreas de fragilidade a erosão muito forte (5), correspondem à unidade geomorfológica Planalto de Biguaçu/Três Riachos e parte do Planalto de Cimeira. São áreas dominadas por colinas e morros, bem como, pela Serra de Santa Filomena, Serra de São Miguel (leste), Serra das Congonhas, Serra do Major e Serra do Macaco Branco (oeste da bacia). É nesse contexto que aparecem, na porção noroeste da bacia, locais com topo de morros mais aplainados (campos de altitudes), onde a fragilidade a erosão é do tipo média (3), conforme o mapa de fragilidade ambiental.

A fragilidade à erosão do tipo forte (4) e muito forte (5), corresponde ao modelado de dissecação da bacia, com o predomínio de rochas graníticas pertencentes ao Complexo Metamórfico-Migmático e Suite Intrusiva Valsungana. Os totais pluviométricos da bacia são elevados, com média de 1800 mm/a em Biguaçu e a média de 2.200 mm/a para Antônio Carlos, que propicia a atuação do intemperismo químico combinado de elevado grau de erosão de solos.

As áreas de terrenos cristalinos corresponde a 76\% do total da bacia, sendo que 40,3\% do embasamento cristalino, possui declividade superior a 25\% (Fortes, 1996, p.30).

Quanto a fragilidade ambiental a inundação da bacia do rio Biguaçu, obteu-se dois tipos: (IV) muito forte (fluvial) e (V) muito forte (marinha), de acordo com a proposta de Ross (1994).

O fenômeno de enchentes e inundações sempre esteve presente na área de estudo, mesmo com a presença de densa cobertura vegetal, anterior ao processo de colonização. O rio Biguaçu destaca-se ao longo do tempo, desde o início do século 20, por eventos de 
inundações históricas. Merece destaque, mencionar a inundação de grande magnitude ocorrida em 1916, pois teve grande repercussão no dia-a-dia das comunidades. Até então, o rio Biguaçu era utilizado como via de navegação fluvial de grande importância econômica para a comunidade do Alto Biguaçu (atual município de Antônio Carlos). Naquela época as estradas eram precárias, e no período das chuvas ficavam intransitáveis, dificultando os deslocamentos de pessoas e de produtos agrícola para o litoral.

A partir de 1966, o poder público inicia obras na bacia do rio Biguaçu. Essas obras de engenharia visavam a retificação de canais fluviais. Varios trechos de rios tributários foram alterados. Atualmente, as enchentes tornaram-se mais raras. Porém, tais intervenções provocaram a retomada erosiva dos rios, contribuindo para o aumento considerável na carga de sedimentos transportada pela corrente em direção à desembocadura do rio Biguaçu. A foz desse rio está assoriada e com baixa profundidade, dificultando o lançamento das águas na baía norte, bem como na navegação de pequenas embarcações no local.

É na planície sedimentar de Biguaçu, onde vive a grande maioria da população, estando sujeita, à ocorrência de episódios de inundações, não sendo necessária haver precipitação excepcional, para que tal fenômeno aconteça. Outro fator que contribui para essa situação é o aumento da população e a ocupação desordenada do solo urbano, promovendo o aumento da impermealização que favore o escoamento superficial. Além disso, a presença da BR-101, na planície marinha, disposta no sentido norte-sul, serve de barreira ao escoamento das águas dos rios Caveiras e Biguaçu. O sistema de drenagem de águas pluviais não é adequado a dar vazão em períodos de chuvas mais intensas. É comum, o surgimento de áreas alagadas embaixo de viadutos da rodovia federal, trazendo transtornos à população.

Outro fator que agrava a situação é a presença de lençol freático próximo à superfície do solo. Em trabalhos de campo verificou-se que os dois rios citados recebem efluentes de esgotos domésticos e comerciais. Até o momento, em Antônio Carlos e Biguaçu não há rede coletora de esgotos e nem estação de tratamento de esgotos. O lançamento de lixo é uma realidade comum nos dois rios, servindo muitas vezes, no represamento das águas, pela presença de material plástico (pet). Já foi observado por nós um boi boiando no rio Biguaçu, próximo da cidade de Biguaçu, durante trabalho de campo, em fevereiro de 2006. 
No Planalto de Cimeira, Planalto de Biguaçu/Três Riachos a densidade de drenagem é elevada, seguindo a disposição das falhas e fraturas. No Planalto de Biguaçu/Três Riachos a drenagem pode estar instalada nos espessos mantos de alteração, que favorecem a concentração das águas pluviais. 


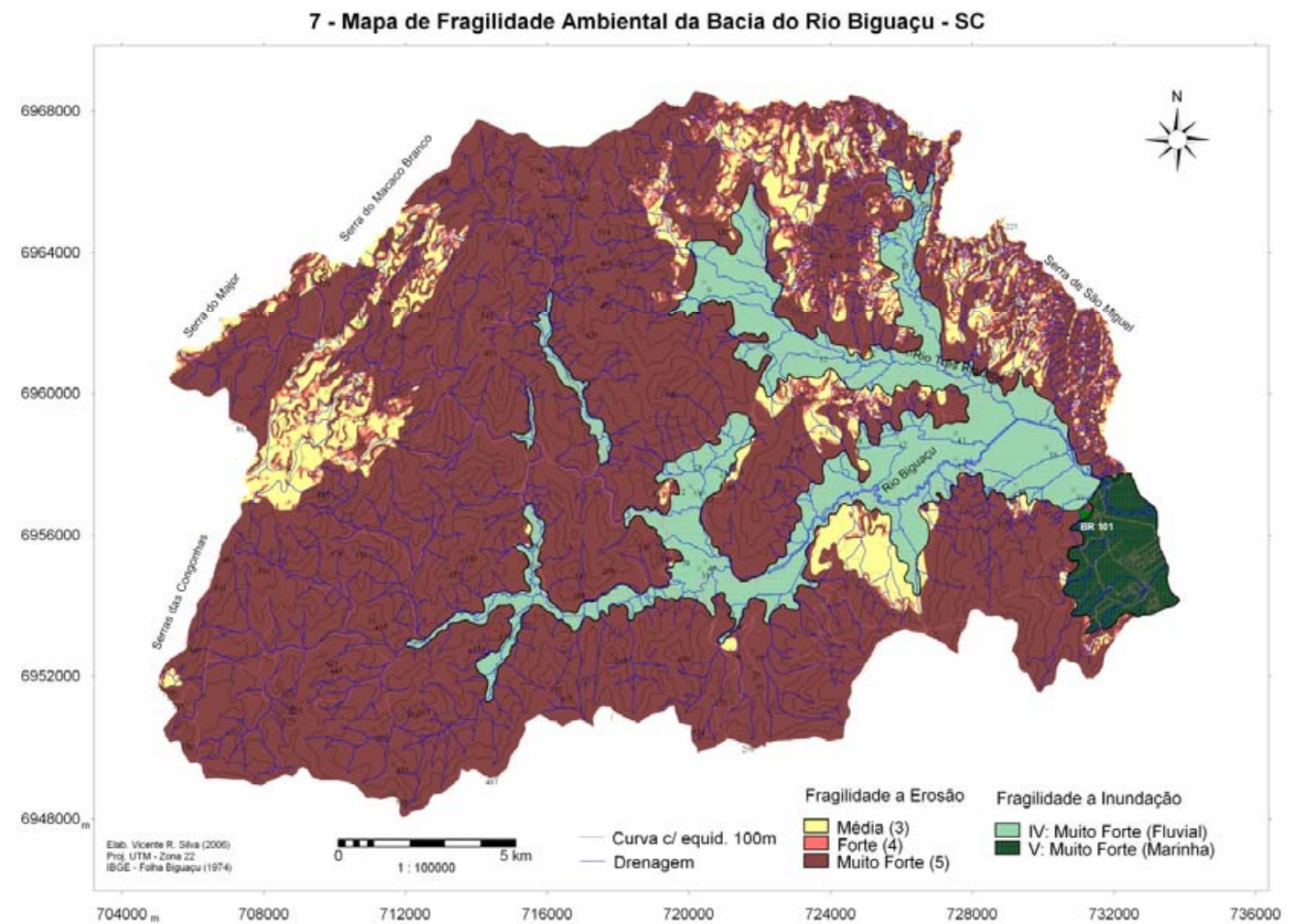

Figura 38 - Mapa de fragilidade ambiental da Bacia do Rio Biguaçu-SC . 


\section{8-Legislação Ambiental}

Um dos objetivos desse estudo é a elaboração de uma proposta de zoneamento ambiental da bacia do rio Biguaçu em Santa Catarina. O zoneamento é um instrumento de ordenamento territorial de base técnico-científica. Nesse aspecto, a legislação ambiental aplicada aos espaços do território onde define categorias de zonas de interesse ecológico/ambiental. Podemos citar como exemplos, as áreas de preservação permanente (APP’s), a proteção legal dos fragmentos florestais da Floresta Ombrófila Densa, o manguezal do rio Biguaçu e a Reserva Particular do Patrimônio Natural (RPPN) do Caraguatá, no município de Antônio Carlos.

A legislação ambiental do Brasil já define “um zoneamento não demarcado em mapas”, mas aplicável ao território do país. Portanto, na realização de estudos visando o ordenamento territorial, os mapas são indispensáveis para "uma melhor dimensão de suas áreas de abrangência” (Ross, 2006, p.204).

Nossa legislação ambiental é formada por um grande "número de leis, decretos, portarias, resoluções e normas que definem, de um modo mais específico, os mecanismos e procedimentos para a proteção, preservação e uso de meio natural” (Bucci et al., 1992, p.89).

A Lei 4771 de 15/09/1965 que institui o Código Florestal Brasileiro é considerado um marco na legislação ambiental. Porém, mais tarde, alguns artigos foram alterados com a nova redação, como o artigo $2^{\circ}$, com destaque para a vegetação de margens de rios, dada pela lei 7.803 de 15/07/1989. O artigo $2^{\circ}$ caracteriza as áreas de preservação permanente (APP), como as florestas e demais formas de vegetação natural e diz textualmente:

A) ao longo dos rios ou de qualquer curso d’água desde o seu nível mais alto em faixa marginal cuja largura mínima seja:

1-de 30 (trinta) metros para os cursos d’água de menos de 10 (dez) metros de largura;

2-de 50 (cinquenta) metros para os cursos d’água que tenham de 10 (dez) a 50 (cinquenta) metros de largura;

3-de 100 (cem) metros para os cursos d’água que tenham de 50 (cinquenta) a 200 (duzentos) metros de largura; 
4-de 200 (duzentos) metros para os cursos d’água que tenham de 200 (duzentos) a 600 (seiscentos) metros de largura;

5-de 500 (quinhentos) metros para os cursos d’água que tenham largura superior a 600 (seiscentos) metros;

B- ao redor de lagoas, lagos ou reservatórios d’água naturais ou artificiais;

C- nas nascentes, ainda que intermitentes e nos chamados “olhos d’água”, qualquer que seja a sua situação topográfica, num raio mínimo de 50 (cinquenta) metros de largura;

D- no topo de morros, montes, montanhas e serras;

E- nas encostas ou partes destas, com declividade superior a $45^{\circ}$, equivalente a $100 \%$ na linha de maior declive;

F- nas restingas, como fixadoras de dunas ou estabilizadoras de mangues;

G- nas bordas de tabuleiros ou chapadas, a partir da linha de ruptura do relevo, em faixa nunca inferior a 100 (cem) metros em projeções horizontais;

H- em altitude superior a 1.800 (mil e oitocentos) metros, qualquer que seja a vegetação.

Através do artigo $2^{\circ}$ da lei 4.771 (15/09/1965), que inside sobre toda a bacia do rio Biguaçu. Nesse inciso a lei é bastante clara e define as áreas de preservação permanente, ao longo dos cursos d’água. Na bacia do rio Biguaçu predominam canais fluviais (em número e extensão), com largura inferior a 10 metros. Assim, de acordo com legislação em vigor, corresponde ao item 1 da letra a, ou seja, a faixa marginal de vegetação natural é de 30 (trinta) metros para cada margem. Também ocorre, em proporção bem menor, em alguns trechos do rio Biguaçu com largura entre 10 e 50 metros. Aplicando a legislação, nesse caso, seria a área de preservação permanente de no mínimo 50 metros para cada margem do canal fluvial.

Na medição de vazão do rio Biguaçu na $1^{a}$ seção, a largura medida foi de $17,35 \mathrm{~m}$, em trecho retificado, no município de Biguaçu. No item 3, do artigo $2^{\circ}$, que prevê 100 metros de faixa marginal de vegetação para os cursos d'água de 50 a 200 metros. Nessa faixa de largura, aplicada ao rio Biguaçu só é encontrada na cidade de Biguaçu. A largura do rio só aumenta a jusante da ponte sobre a BR 101. Na medição de vazão da $2^{a}$ seção, obteve-se cerca de 57,0 metros de largura. 
Um dos principais problemas ambientais da área de estudo é a questão da ausência de vegetação na faixa marginal dos canais fluviais. Fatores de ordem histórica, cultural e econômica, aliado ao tipo de estrutura agrária vigente nos municípios de Antônio Carlos e Biguaçu, onde predomina as pequenas propriedades rurais. O uso intensivo da terra com horticultura e plantio de grama por parte dos agricultores acarreta a exploração econômica das terras próximas aos rios (planície de inundação). Em geral, as áreas de planície fluvial, possuem relevo plano e solo adequado, sendo intensamente exploradas. Porém, o uso da terra com pastagens que ocupam vastas áreas, geralmente, não respeitam os limites das APP nas margens dos rios da região. Esse problema é mais comum no médio e baixo cursos dos rios: Biguaçu, Três Riachos, Rachadel, Louro, dentre outros tributários.

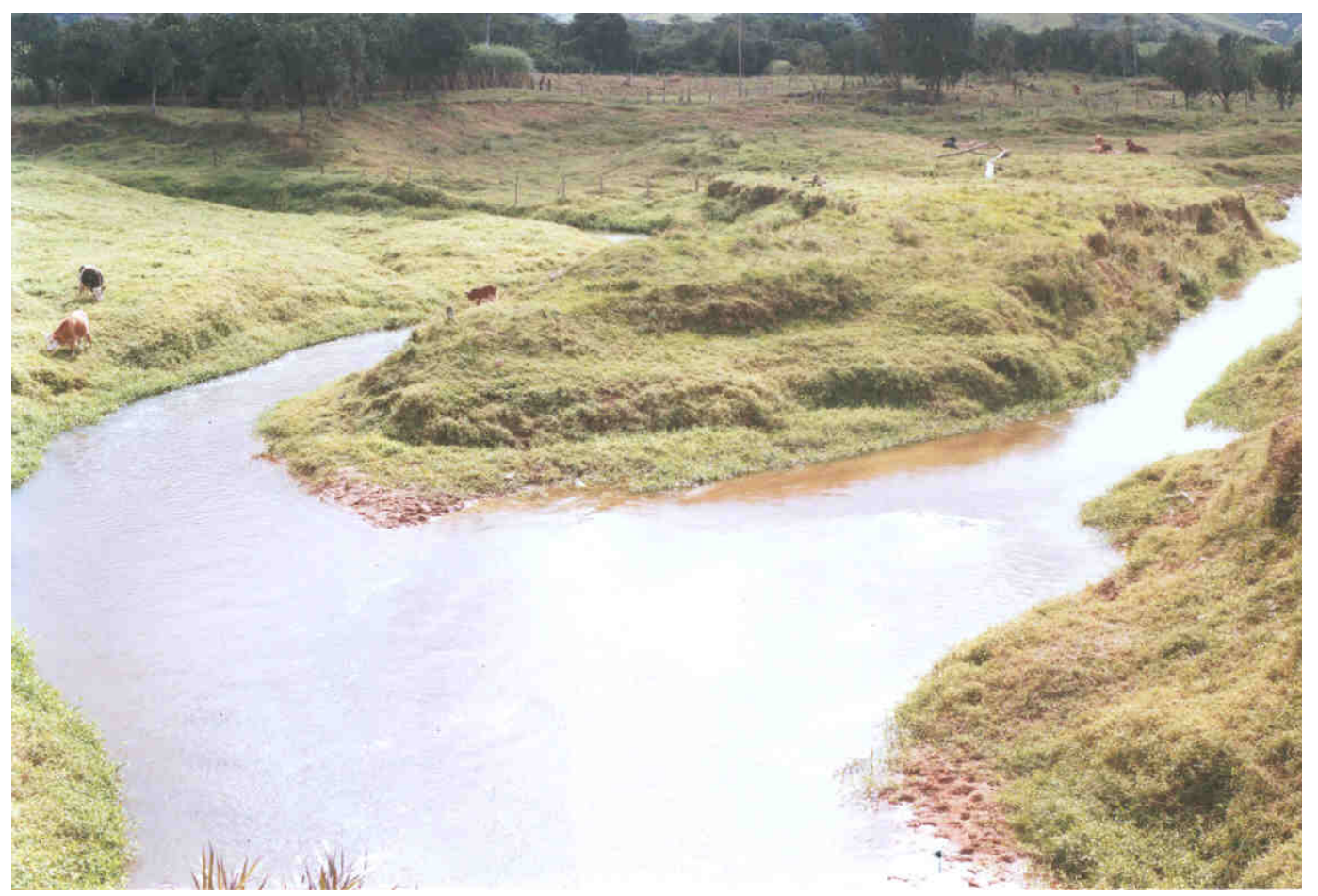

Figura 39 - Foz do rio Farias (direita) no rio Biguaçu (esquerda), em área da planície fluvial. Predomina o uso da terra com pastagens e ausência de mata ciliar, município de Antônio Carlos-SC. (Foto Ivanete Nardi, maio/2003).

O código florestal é uma "lei que regulamenta o uso e conservação das florestas e demais formas de vegetação, estando bem definidos, dando ao Estado o poder de polícia para a sua proteção" (Bucci, 1992, p.92). Um dos maiores desafios do poder público refere-se à falta de infra-estrutura dos órgãos ambientais estaduais e federal, no caso do estado de Santa Catarina, a Fatma e o Ibama, respectivamente. A fiscalização é precária e em geral, só ocorre 
mediante denúncia. Os recursos humanos são insuficientes para atender a demanda na proteção do ambiente. A ausência de mata ciliar na maioria dos rios da área de estudo foi constatada desde o início da pesquisa, em maio de 2003.

No mapa de ocupação e uso da terra 2006 e mapa de legislação ambiental estão delimitados os polígonos do ecossistema manguezal do rio Biguaçu, cujo código florestal (1965) prevê como área de preservação permanente, conforme o artigo $2^{\circ}$, letra f. Apesar da legislação vigente, o manguezal tem sido intensamente degradado. Em trabalho de campo no local, verificaram os principais tensores: desmatamentos, aterros e instalação de moradias sobre o manguezal, deposição de lixo, dentre outros. O Código Florestal, cita a proteção no seu artigo $2^{\circ}$, letras: c, d, e. As nascentes do rio Biguaçu, bem como dos principais formadores da bacia, estão situadas nas áreas de ocorrência de rochas cristalinas (Planalto de Cimeira). Também ocorre, a presença em alguns locais com encostas com declividade superior a 45\%. Os tipos de morros e serras ocorrem nas porções leste, norte, sul e oeste da bacia.

Uma das características mais significativas do meio rural catarinense é a presença das pequenas propriedades, com áreas de até 30 ha. Na área de estudo, predominam os minifúndios, onde geralmente, as terras são drenadas por cursos d’água. Com o advento do parcelamento das terras, em geral, pelo fator herança, as propriedades rurais tornam-se cada vez menores e muitas com dimensões inferiores a 10 ha. Para esse tipo de propriedade que, na maioria das vezes, utiliza mão-de-obra familiar, a manutenção de área de preservação permanente é problemática. Para estas propriedades a manutenção da área de preservação permanente entre rios de $30 \mathrm{~m}$ e em nascentes de $50 \mathrm{~m}$, pode reduzir significativamente a área explorada na propriedade rural. No entanto, a manutenção da pequena propriedade não se efetivará com a exploração sem critério de áreas protegidas pela legislação (Paiva, 2004, p.94). 


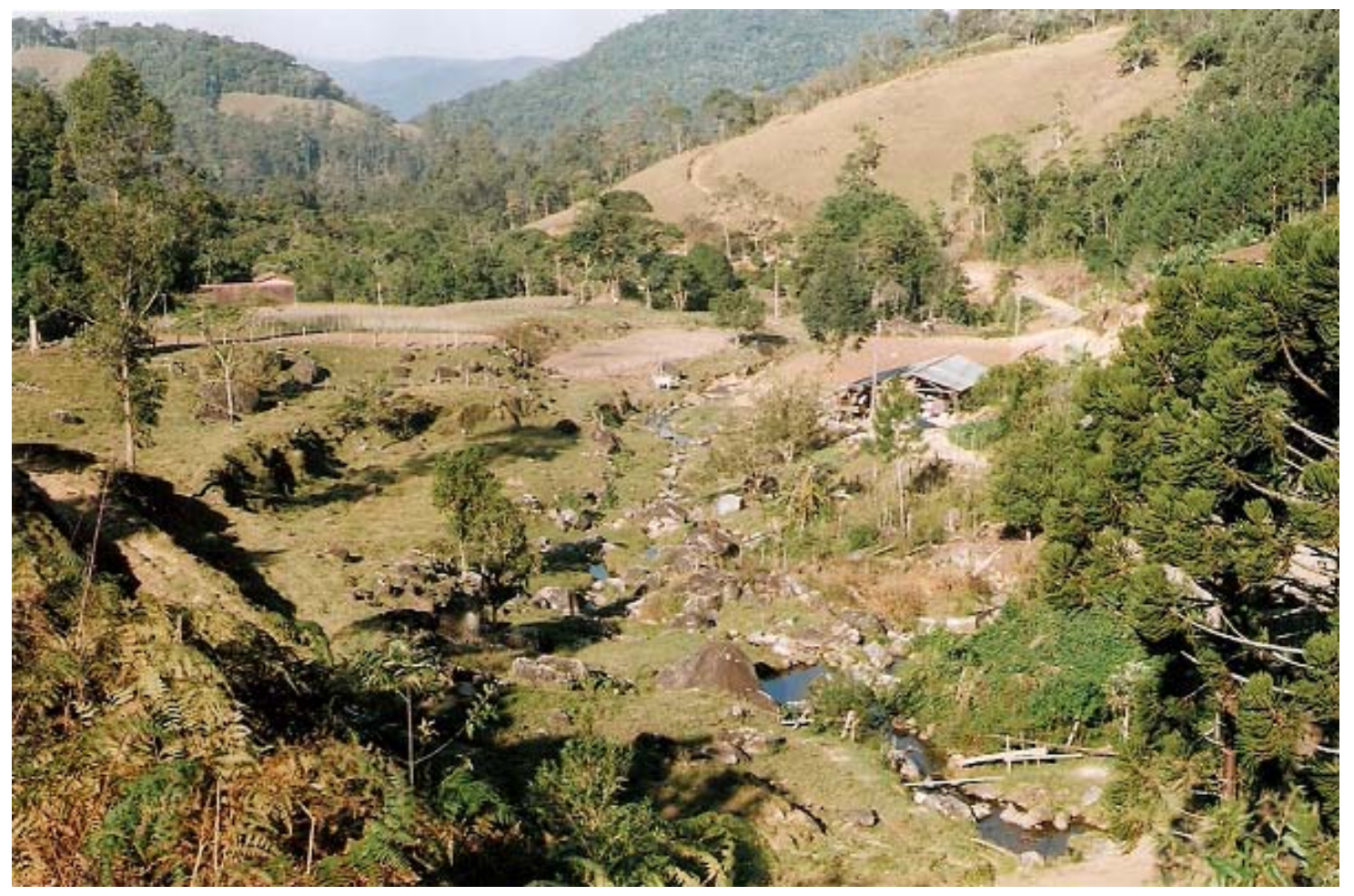

Figura 40 - Vista panorâmica do alto vale do Rio Rancho Miguel, à jusante da cachoeira do rio, no município de Antônio Carlos - SC. (Foto: Vicente R.Silva, julho/2006).

Segundo a autora (op. cit.), o uso inadequado da faixa ciliar pode gerar danos ambientais que irão refletir sobre a qualidade de vida do produtor. Assim sendo, o manejo incorreto do solo tem provocado o carreamento de resíduos, sendo estes depositados nas beiras dos rios, pelas chuvas, chegando até os canais fluviais. Nessas condições, pode ocorrer a criação de populações de insetos nocivos, como por exemplo, os borrachudos (Deptera: simuliidae) (Paiva, 2004, p.95). A Prefeitura Municipal de Antônio Carlos vem desenvolvendo campanhas junto às comunidades rurais do município visando combater a proliferação dos mosquitos borrachudos.

Recentemente, o governo federal sancionou a Lei $\mathrm{n}^{0}$ 11.428, de 22 de dezembro de 2006, que dispõe sobre a utilização e proteção da vegetação de Mata Atlântica. Essa lei define no seu artigo $2^{\circ}$, o domínio de Mata Atlântica, segundo "as formações florestais nativas e ecossistemas denominados: Floresta Ombrófila Densa; Floresta Ombrófila Mista; Floresta Ombrófila Aberta; Floresta Estacional Semidecidual; e floresta Estacional Decidual, bem como os manguezais, as vegetações de restinga, campos de altitude, brejos interioranos e enclaves florestais do Nordeste”. 
Porém, na bacia do rio Biguaçu temos os seguintes tipos de vegetação: Floresta Ombrófila Densa, Floresta Ombrófila Mista, Manguezal e Campos de Altitude. Essa lei objetiva legislar sobre a vegetação de mata atlântica, nos estágios primário e secundário (inicial, médio e avançado de regeneração).

A área de estudo possui algumas áreas limitadas de remanescentes de floresta primária de mata atlântica. São fragmentos de diferentes dimensões, em geral, com inserções de vegetação secundária e reflorestamentos (Leite, 2003, p.12). Os maiores fragmentos da Floresta Ombrófila Densa, na grande maioria sendo de capoeirões, localizam-se na porção oeste da bacia.

No capítulo II da Lei n 11.428 , define que a proteção e utilização do domínio de Mata Atlântica tem como objetivo o "desenvolvimento sustentável”. Também, cita os objetivos específicos, "salvaguarda da biodiversidade, da saúde humana, dos valores paisagísticos, estéticos e turísticos, do regime hídrico e da estabilidade social”. Ainda no capítulo II descreve que a proteção e utilização da mata atlântica deve ser de acordo com o artigo $7^{\circ}$, inciso IV, que diz: "o disciplinamento da ocupação rural e urbana, de forma a harmonizar o crescimento econômico com a manutenção do equilíbrio ecológico.” Sendo assim, a elaboração nesta pesquisa de uma proposta de zoneamento ambiental da bacia, torna-se um instrumento de grande utilidade no ordenamento territorial ambiental.

Através do artigo 11, a lei reforça o caráter restritivo em relação ao corte e supressão da vegetação primária e de vegetação secundária, definindo a proibição: a)”abrigar espécies de flora e fauna silvestres ameaçadas de extinção, em território nacional ou em âmbito estadual, (...)”; b) “exercer a função de proteção de mananciais ou de prevenção e controle de erosão”; c)” formar corredores entre remanescentes de vegetação primária ou secundária em estágio avançado de regeneração”; d)” proteger o entorno de unidades de conservação”;

No contexto da bacia do rio Biguaçu, o artigo 11 é pertinente, para todas as quatro condições citadas acima. Podemos destacar, por exemplo, o rio Farias que é utilizado como manancial, desde 1992, pela Casan (empresa pública estadual), para o abastecimento de água tratada da cidade de Antônio Carlos. Além da mata atlântica ser dominante, há também, a presença da Araucária (Floresta Ombrófila Mista). Há condições favoráveis a exercer a função de corredores ecológicos nas áreas de matas de alguns municípios limitrofes com 
Antônio Carlos e Biguaçu. A presença da Unidade de Conservação RPPN Caraguatá é uma referência importante na manutenção e preservação de mata atlântica no litoral de Santa Catarina.

No artigo 14, a lei dispõe sobre em quais situações a vegetação primária e secundária (capoeirões) poderá ser suprimida, apenas em casos de utilidade pública, devidamente caracterizada, quando não existir alternativa técnica e locacional ao empreendimento proposto. O artigo 14, prossegue no parágrafo $2^{\circ}$, que diz: “A supressão de vegetação no estágio médio de regeneração situada em áreas urbanas dependerá de autorização do órgão ambiental municipal competente, desde que o município possua Conselho Municipal de Meio Ambiente, com caráter deliberativo e plano diretor, mediante anuência prévia do órgão ambiental estadual competente, fundamentada em parecer técnico”

Em Biguaçu, o plano diretor está sendo revisado. O último foi elaborado em 1995. A municipalidade possui Conselho Municipal de Meio Ambiente, porém não é atuante. No município de Antônio Carlos o plano diretor está em elaboração e existe Conselho Municipal de Meio Ambiente, sendo denominado de Comama e criado pela lei $\mathrm{n}^{\mathrm{o}} 1037$ de 2005. Segundo o Secretário de Municipal de Agricultura, o conselho é atuante (inf. verbal, abril/2007).

O artigo 20, que evidência a proteção da vegetação secundária, de forma complementar ao dispositivo da redação do artigo 14, diz: “O corte e supressão da vegetação primária de mata atlântica somente será autorizado em caráter excepcional, quando necessária a utilização de obras, projetos ou atividades de utilidade pública, pesquisa científica e práticas prevacionistas”(artigo 20).

Na lei $n^{0} 11.428$, através do artigo 30 são definidas restrições à supressão de mata atlântica em áreas urbanas e regiões metropolitanas, conforme incisos I e II, descrevendo as situações: I- nos perímetros urbanos aprovados até o início de vigência desta lei, a supressão de vegetação secundária (capoeirões), dependerá de autorização prévia de órgão estuadual, para fins de loteamento ou edificação, se for garantida no minímo 50 \% da área total coberta por essa vegetação. Além disso, deve estar de acordo com dispositivos do Plano Diretor do Município. II- nos perímetros urbanos aprovados após a data de início de vigência desta lei, é 
vedada a supressão da vegetação secundária (capoeirões) de mata atlântica, destinado a loteamentos e edificações.

No artigo 31, há uma complementação dessas restrições, citadas acima, que diz: o parcelamento do solo para loteamento ou edificação em área de vegetação secundária (estágio médio de regeneração), da mata atlântica, deve seguir as normas previstas no Plano Diretor do Município. No parágrafo $1^{\circ}$, está estabelecido que nos perímetros urbanos aprovados até a data de início da vigência dessa lei, que o empreendimento deve garantir a manutenção de no mínimo 30\% da área total de vegetação. No parágrafo $2^{\circ}$, diz que nos perímetros urbanos delimitados após a data de início de vigência dessa lei, a supressão de vegetação secundária (estágio médio de regeneração) deve garantir a manutenção de no mínimo 50\% da área total de vegetação. Essa lei apresenta a possibilidade de incentivos econômicos a proprietários e posseiros, visando a proteção e uso sustentável de mata atlântica. Foram definidas algumas condições, sendo assim, destacamos os incisos do artigo 33:

I- a importância e representatividade ambientais do ecossistema e da gleba; II-a existência de espécies da fauna e flora ameaçadas de extinção; III- a relevância dos recursos hídricos; IVo valor paisagístico, estético e turístico; V- o respeito às obrigações impostas pela legislação ambiental; VI- a capacidade de uso real e sua produtividade atual.

E por último, é a criação do Fundo de Restauração de Mata Atlântica, destinado ao financiamento de projetos de restauração ambiental e de pesquisa científica. Os recursos do fundo seriam de dotações orçamentárias da União (item I), dentre outros. No artigo 38, esclarece-se que os recursos do Fundo de Restauração de Mata Atlântica serão implementados em municípios que possuam plano municipal de conservação e recuperação da mata atlântica, devidamente aprovado pelo Conselho Municipal de Meio Ambiente. Esse fundo poderá ser utilizado, por exemplo, na recuperação das matas ciliares nos dois municípios integrantes da bacia do rio Biguaçu.

A constituição federal de 1988, em vigor, tranformou todos os corpos de água, que passaram a ser de domínio público. Foram definidos dois tipos de domínios para os corpos d’água, os da União e os dos Estados. No caso do rio Biguaçu, ora objeto de nossa pesquisa, pertence ao domínio do Estado de Santa Catarina. 
Deve-se ressaltar, por meio da lei sobre os recursos hídricos, editada em 1997, define a bacia hidrográfica como unidade de planejamento e gestão das águas superficiais do país. A utilização do princípio de usos múltiplos da água que permite a todas as categorias de usuários da água em igualdade de condições de acesso, tirando o monopólio de gestão do setor elétrico. A legislação inova no reconhecimento do valor econômico da água, dando condições de práticas de uso racional da água. Para isso, é instituida a possibilidade de cobrança pela utilização da água.

A lei 9.433/97, no cap. IV estabelece os intrumentos da política do setor, através dos Planos de Recursos Hídricos. O segundo instrumento, item II, é o enquadramento dos corpos d’água em classes de usos proponderantes. Nesse aspecto, refere-se aos níveis de qualidade de água dos mananciais. Esse enquadramento é importante às comunidades envolvidas sobre influência do Rio Biguaçu, nos municípios de Antônio Carlos e Biguaçu. A formulação de meta de qualidade a ser alcançada, visa atender a todas as categorias de usuários. O rio Farias é usado como manancial no abastecimento público de Antônio Carlos. Na agricultura, a produção de horticultura e grama depende da água de irrigação do rio Biguaçu e outros tributários. Além disso, também pode ser usada para a navegação e o lazer. Porém, até o presente momento, não foi criado o Comitê da bacia do Rio Biguaçu.

Conforme prevê a referida lei, na seção I dos planos de recursos hídricos, por meio do artigo 7, destacado a seguir:

I-diagnósticos da situação atual dos recursos hídricos;

II-análise de alternativas de crescimento demográfico, de evolução das atividades produtivas e de modificações dos padrões de ocupação do solo;

III-balanço entre disponibilidade e demandas futuras dos recursos hídricos, em quantidade e qualidade, com identificação de conflitos potenciais;

IV-metas de racionalização de uso, aumento da quantidade e qualidade dos recursos hídricos disponíveis.

Também, podemos apontar outros avanços na gestão dos recursos hídricos do Brasil, como o artigo 9, que descreve sobre o enquadramento dos corpos de água em classes, segundo os usos preponderantes da água, visa: I-assegurar às águas qualidade compatível com 
os usos mais exigentes a que forem destinadas; II- diminuir os custos de combate à poluição das águas, mediante ações preventivas permanentes.

A base legal para a política e gestão dos recursos hídricos no Brasil está baseada na lei federal $n^{\circ} 9.433$ de 8 de janeiro de 1997. A lei define no capítulo I, dos fundamentos da Política Nacional de Recursos Hídricos:

I- a água é um bem de domínio público;

II- a água é um recurso natural limitado, dotado de valor econômico;

III- em situação de escassez, o uso prioritário dos recursos hídricos é o consumo humano e a dessedentação de animais;

IV- a gestão dos recursos hídricos deve proporcionar o uso múltiplo das águas;

V- a bacia hidrográfica é a unidade territorial para implantação da Política Nacional de Recursos Hídricos e a atuação do Sistema Nacional de Gerenciamento de Recursos Hídricos.

VI- a gestão dos recursos hídricos deve ser descentralizada e contar com a participação do Poder Público, dos usuários e das comunidades.

Desde a criação do código florestal em 1965, através do artigo $2^{\circ}$, já era permitido aos “proprietários de florestas não preservadas, poderá gravá-la com perpetuidade”. O vínculo será “averbado à margem da inscrição no registro público”. No entanto, o artigo $6^{\circ}$ foi revogado pela Lei 9985 de 18/07/2000, que institui o Sistema Nacional de Unidades de Conservação da Natureza.

A única unidade de conservação presente na área de pesquisa é a RPPN Caraguatá, situada no extremo noroeste da bacia e criada em 1990. O decreto ${ }^{\circ} 98.914$ de 1990, instituiu as RPPNs, ou seja, Reservas Particulares do Patrimônio Natural. Somente no ano de 2000, através da Lei 9985 de 18 de julho de 2000 é que as RPPNs são reconhecidads como unidades de ,conservação de uso sustentável. O embrião para a sua criação deve-se ao Código Florestal (lei 4771 de 1965).

As RPPNs são áreas destinadas à conservação da natureza em propriedades particulares. O objetivo é de legitimar as intenções conservacionistas de proprietários rurais. As RPPNs podem ser criadas em qualquer tipo de domínio e ou ecossistema. A criação de uma RPPN é vontade livre e exclusiva dos proprietários. Na lei 9.985 (18/07/2000), do 
SNUC, as RPPNs podem funcionar como corredores ecológicos, conforme seu artigo $2^{\circ}$, inciso $\mathrm{n}^{\circ}$ XIX. Os corredores ecológicos são: “porções de ecossistemas naturais ou seminaturais, ligando unidades de conservação, que possibilitam entre elas o fluxo de genes e o movimento da biota, facilitando a dispersão de espécies e a recolonização de áreas degradadas, bem como a manutenção de populações que demandam para sua sobrevivência áreas com extensão maior do que aquela das unidades individuais”.

As RPPNs se enquadram na categoria de unidade de conservação do tipo II Unidades de Uso Sustentável. Segundo o artigo $7^{\circ}$, parágrafo $2^{\circ}$ “o objetivo básico das unidades de uso sustentável é compatibilizar a conservação da natureza com o uso sustentável de parcela dos seus recursos naturais”. No artigo 21 da Lei 9.985 (18/07/2000), define a Reserva Particular do Patrimônio Natural como “uma área privada, gravada com perpetuidade, com objetivo de conservar a diversidade biológica”. Nesse tipo de unidade de conservação só é permitida a pesquisa científica, a visitação com objetivos turísticos, recreativos e educacionais.

Na lei do SNUC, no seu artigo 21, parágrafo $3^{\circ}$, prevê a elaboração de um plano de manejo ou de proteção e de gestão da unidade. Apesar da unidade de conservação Caraguatá ter sido criada em 1990, o Plano Básico de Utilização (PBU) só foi realizado em 2003. Nesse referido plano foi proposta a realização de educação ambiental. Segundo informações obtidas na Prefeitura Municipal de Antônio Carlos, estudantes de escolas do município têm realizado visitas na RPPN Caraguatá. Foi constatado no estudo que a unidade de conservação se mantinha muito fechada para a comunidade até 2003. Foi recomendada, a necessidade de maior integração com a comunidade de entorno, na vida econômica e social das comunidades vizinhas.

De acordo com o artigo 26 da lei 9.985 (18/07/2000), do SNUC, não é necessário que as RPPNs possuam uma zona de amortecimentos (zona tampão) e em certos casos os corredores ecológicos. Acreditamos, porém, que as RPPNs, deveriam ter zona de amortecimento, visando uma proteção mais efetiva, baseada na adequação dos usos dos recursos naturais. através de uma proposta de ordenamento territorial com o objetivo de compatibilizar a exploração econômica dos recursos com conservação ambiental. 


\section{Reserva Ecológica do Caraguatá (RPPN)}

Trata-se de uma Reserva Particular do Patrimônio Natural (RPPN), de propriedade de Russell Wid Coffin. A reserva foi criada em 1990, com área inicial de 1.854 ha, atráves da portaria 645/90 de 03/05/90 do Ibama. Posteriormente, foi ampliada para 3.313 ha (Portaria 01/98 e 61/98 do Ibama). Atualmente a reserva possui 4.300 hectares.

Segundo informações levantadas, a área averbada é bem definida com a realização de levantamentos topográficos, já demarcada e sem litígios territoriais. O perímetro urbano e sinalizado com piquetes e placas de identificação.

A RPPN está localizada entre os municípios de Antônio Carlos, São João Batista, Major Gercino, Angelina e Biguaçu, em Santa Catarina. Estão inseridas na reserva as Serras do Major, Macaco Branco e Boa Vista. As altitudes variam de 400 metros a 903 metros. Nascem dentro da reserva vários rios como o Arataca, Fernandes, Inferninho e Rachadel. Os rios Farias e Rachadel integram a bacia do rio Biguaçu. O rio Farias é utilizado como manancial para o abastecimento público da cidade de Antônio Carlos.

Mais de 60\% da área total da RPPN Caraguatá fica no município de Antônio Carlos. Nela ocorrem as formações de mata atlântica, mata de araucárias e campos naturais. No morro do Pai João é o ponto de maior altitude, com aproximadamente 910 metros.

Na reserva é expressiva a cobertura vegetal formada por grande parte de floresta primária e a interpenetração de dois dos três principais formações florestais no estado de Santa Catarina. No local são encontradas a Floresta Ombrófila Densa (formação montana), a Floresta Ombrófila Mista (formação montana). Também, há presença de áreas menores de formações campestres (campos de altitudes), formando campos hidromórficos ou turfeiras.

A Floresta ombrófila Mista predomina nas encostas declinosas dos morros, nas porções baixa, média e alta encosta. Na reserva foram identificados alguns problemas: acontaminação biológica de espécies de vegetação exótica, com potencial invasoras; bpresença de áreas com silvicultura com espécies exoticas; c- extração ilegal de palmito; dpresença do capim braquiária (Brachyaria mutica), limoeiro de origem asiática. De acordo com informações disponíveis no site da reserva, antes da criação da RPPN, alguns locais eram utilizados como pastagens, cultivos agrícolas e extrativismo de madeiras nobres. 
A administração tem realizado a recuperação desses locais com o plantio de espécies nativas, principalmente de araucárias. A maior parte da reserva caraguatá está no município de Antônio Carlos, localizada na porção noroeste, sendo cartografada no mapa de legislação ambiental e no mapa de zoneamento ambiental da bacia do rio Biguaçu.

\section{1-Mapa de Legislação Ambiental}

No conjunto este mapa mostra o predomínio da ocupação de Mata Atlântica, através da vegetação secundária (capoeirões e capoeiras). Dentro da área de estudo, formada hoje por vegetação secundária, há remanescentes de floresta primária, notadamente na porção oeste da bacia (Planalto de Cimeira). Estes fragmentos são de difícil identificação e delimitação, não sendo possível serem cartografados e limitações da escala do mapa. É na unidade de conservação, RPPN Caraguatá, uma das primeiras a serem criadas no Brasil, o local onde a Floresta Ombrofila Densa está melhor preservada no litoral em Santa Catarina.

Há também, remanescentes da Floresta Ombrófila Mista (Mata de Araucária) e de campos de altitude. Essa Unidade de Conservação está localizada nos municípios de Angelina, Antônio Carlos, Major Gercino, São João Batista e Biguaçu, em Santa Catarina. No entanto, no mapa de legislação ambiental, só está representada a área ocupada no município de Antônio Carlos, que integra a bacia do rio Biguaçu. A RPPN Caraguatá é a maior área preservada de mata atlântica do estado de Santa Catarina. De sua área total de 4300 ha, mais de 60\% fica no território do município de Antônio Carlos. Lá é o local onde estão as nascentes dos rios Farias e Rachadel, que integram a margem esquerda do rio Biguaçu. O rio Farias é usado como manancial pela Casan, desde 1992, sendo que abastece com água tratada o distrito-sede de Antônio Carlos e a localidade de Guiomar. Além disso, já abastece algumas localidades no município vizinho de Biguaçu.

O manguezal do rio Biguaçu localiza-se a leste da bacia, presente nas duas margens, próximo à foz na baía norte. Com relação ao uso da terra, foram cartografadas as áreas com agricultura e pecuária. De modo geral, a exploração econômica das terras segue os traçados dos rios e ribeirões. Nos locais mais favoráveis às atividades, com relevo plano e baixa declividade, ocorreu o desmatamento e implantação da prática agropecuária. Os locais de uso intensivo estão nas planícies fluviais dos rios da bacia. As planícies fluviais mais utilizadas são dos rios Três Riachos, Saudade, do Louro, de Guiomar, Farias, Rachadel, Biguaçu e 
ribeirão Vermelho. As duas manchas urbanas das cidades de Antônio Carlos e Biguaçu, estão incluídas nessa classe.

Em relação à lesgislação ambiental que prevê a preservação da mata ciliar nas áreas de preservação permanente (APP), foram definidas quatro classes: cabeceiras dos canais fluviais (50 metros), faixa de APP de 30 metros, faixa de APP de 50 metros e faixa de APP de 100 metros. Todos os principais canais fluviais na zona de cabeceiras foram cartografados no mapa, por meio de um pequeno círculo. Já com relação à faixa de APP de 30 metros foi a dominante em número de canais e extensão, para o rios com menos de 10 metros de largura. Para a faixa de 50 metros, definido apenas para um trecho do rio Biguaçu, na altura da cidade de Antônio Carlos até a ponte sobre a BR-101 do referido rio. E por último, a menor extensão do rio Biguaçu que vai da ponte da BR-101 sobre rio até a foz na baía norte, com faixa de APP de 100 metros para cada margem, pois o rio tem mais de 50 metros de largura.

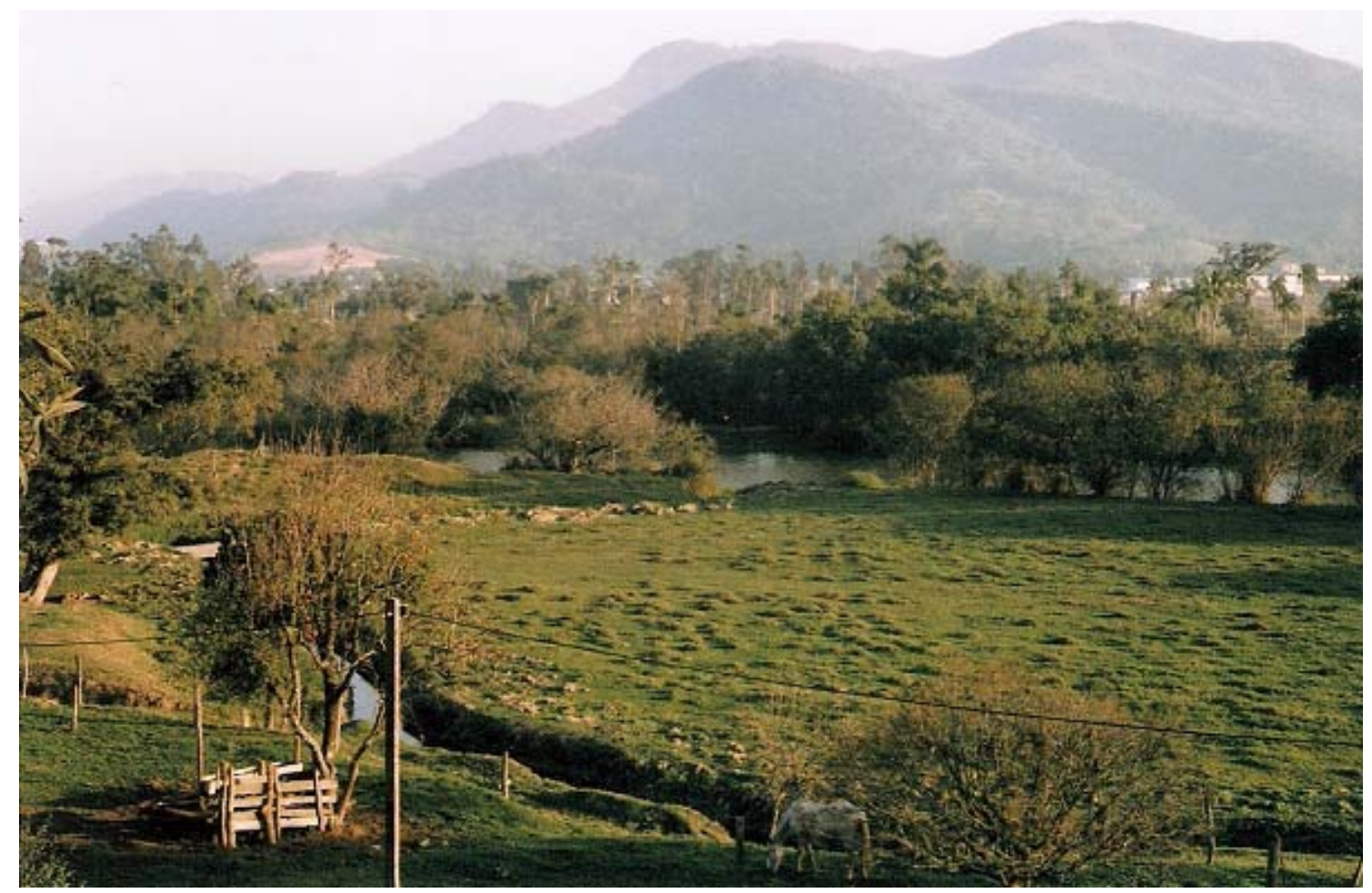

Figura 41-Planície fluvial no baixo curso do rio Biguaçu, com pastagens na margem esquerda.Bairro do Prado, no município de Biguaçu-SC. (Foto: Vicente R. Silva, julho/2006). 


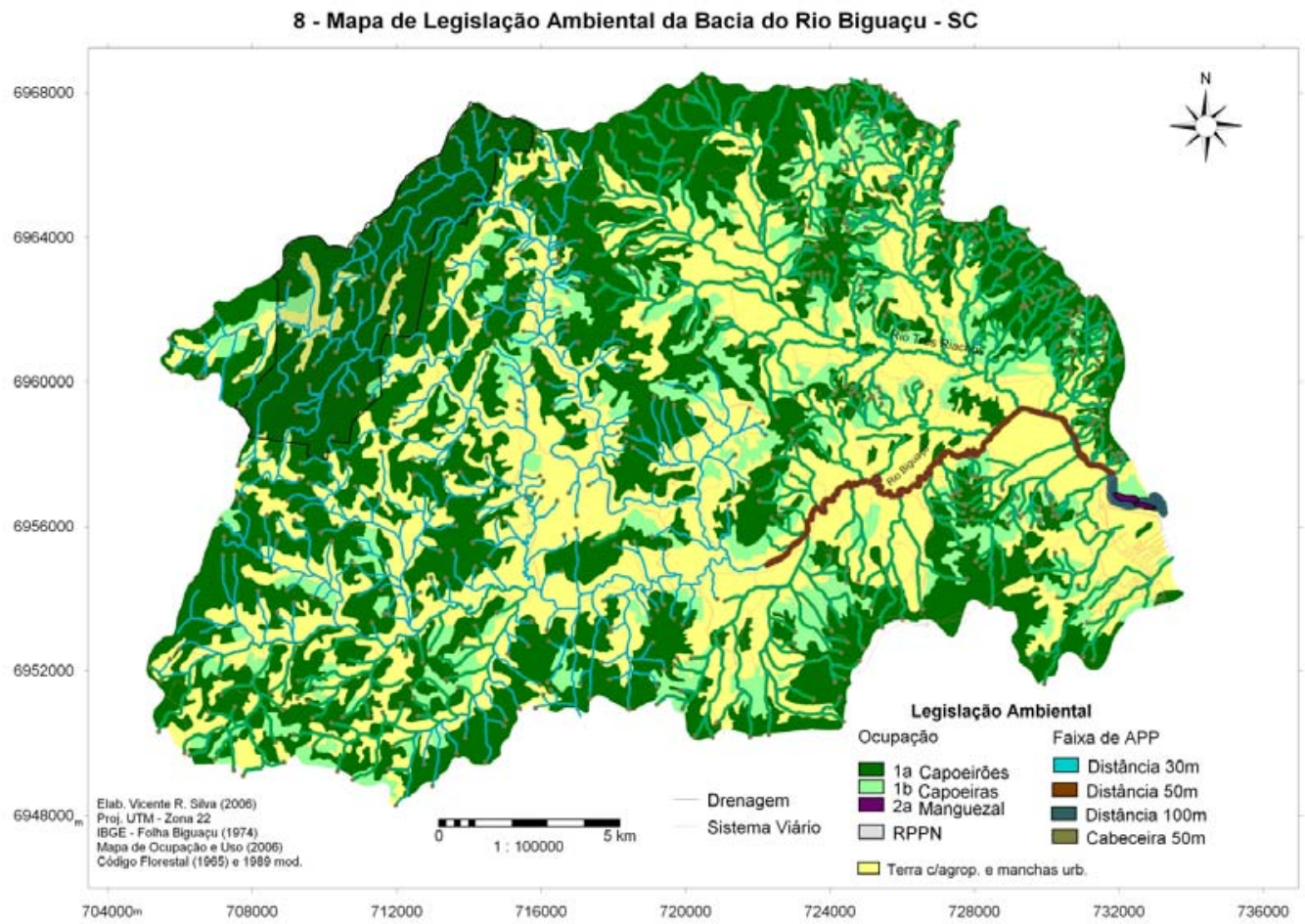

Figura 42 - Mapa de legislação ambiental da bacia do Rio Biguaçu-SC. 


\section{9-Diretrizes para o ordenamento territorial e ambiental}

Unidades de intervenção

Com base nos estudos dos componentes da natureza presentes na área de estudo, foram propostas seis unidades de intervenção e gestão, divididas em três tipos: frágeis, medianamente frágeis e medianamente estáveis. O quadro a seguir demostra essa divisão Áreas Propostas

Quadro 1 - Unidades de intervenção da bacia do rio Biguaçu-SC.

\begin{tabular}{|l|l|l|}
\hline \multirow{2}{*}{ TIPOS DE ÁREAS } & \multicolumn{2}{|l|}{ SISTEMAS AMBIENTAIS } \\
\hline \multirow{2}{*}{ Áreas Frágeis } & Marinha & Mar e praia \\
\cline { 2 - 3 } & Flúvio-marinha & Manguezal e cristas praiais \\
\cline { 2 - 3 } & Planície fluvial & Ribeirinhas \\
\hline Áreas Medianamente Frágeis & Serra de São Miguel & Vertentes (encostas) \\
\cline { 2 - 3 } & Áreas dissecadas & Planalto de Biguaçu/Três Riachos \\
\hline Áreas Medianamente Estáveis & Planalto & Planalto de Cimeira \\
\hline
\end{tabular}

As unidades de intervenção possuem estreita relação com as fisionomias naturais (relevo e ecossistemas). As potencialidades econômicas e sociais da bacia do rio Biguaçu estão relacionadas ao sistema de produção que vigora na atualidade. As atividades de maior expressão e agregação de valor econômico são representadas pela agricultura (horticultura, plantio de grama e frutas), no município de Antônio Carlos e a indústria de material plástico, plantio de grama e hortaliças, no município de Biguaçu. O turismo no município de Antônio Carlos é baseado nas belezas naturais, sendo explorado apenas através dos seis parques aquáticos.

Problemas, limitações e potencialidades

Os problemas ambientais configurados foram levantados em trabalhos de campo. A vulnerabilidade aos processos naturais atuantes sobre cada sistema e acentuada por impactos 
ambientais negativos, oriundos de uma ocupação desordenada do meio físico-biótico (MMA, 2002, p.60). As estratégias de utilização dos recursos naturais devem estar apoiadas na capacidade produtiva e do equilíbrio ambiental, de acordo com cada sistema. É através da concepção de “desenvolvimento sustentável”, que se deve nortear a exploração econômica dos recursos da natureza. As atividades econômicas devem ser conduzidas por meio da convivência harmônica, segundo as fragilidades e potencialidades do meio físico-biótico, visando sempre a qualidade ambiental e o bem estar da sociedade.

Situação atual por unidade de intervenção

Quadro 2 - Situação atual por unidade de intervenção - áreas frágeis

\begin{tabular}{|c|c|c|c|}
\hline \multicolumn{4}{|c|}{ Áreas Frágeis } \\
\hline \multicolumn{4}{|c|}{ Marinha (baía norte e praia) } \\
\hline Limitações & Ocup. e.Uso da Terra & Problemas & Potencial \\
\hline Sedimentação & $\begin{array}{l}\text { Pesca artesanal, com uso de } \\
\text { redes e anzóis;navegação } \\
\text { com barcos peq. Porte }\end{array}$ & $\begin{array}{l}\text { Assoreamento da baía norte; } \\
\text { poluição por esgotos; lixo }\end{array}$ & $\begin{array}{ll}\text { Navegabilidade, } & \text { exploração } \\
\text { peixes; } & \text { patrimônio } \\
\text { paisagístico } & \end{array}$ \\
\hline \multicolumn{4}{|c|}{ Flúvio marinha } \\
\hline $\begin{array}{l}\text { Solos muito mal drenados, } \\
\text { com baixa fertilidade }\end{array}$ & $\begin{array}{l}\text { Moradias; vegetação restrita; } \\
\text { pecuária } \\
\text { extensiva;indústrias }\end{array}$ & $\begin{array}{l}\text { Impermeabilização dos solos; } \\
\text { ocupação desordenada do } \\
\text { solo; poluição por esgotos; }\end{array}$ & \begin{tabular}{|lr} 
Educação & ambiental; \\
preservação & da \\
biodiversidade &
\end{tabular} \\
\hline \multicolumn{4}{|c|}{ Manguezal } \\
\hline $\begin{array}{l}\text { Área alagável; substrato } \\
\text { inconsistente; salinização. }\end{array}$ & Moradias & $\begin{array}{l}\text { Desmatamentos; aterros; lixo; } \\
\text { agrotóxicos. }\end{array}$ & $\begin{array}{l}\text { Educação ambiental; } \\
\text { ecoturismo; preservação da } \\
\text { biodiversidade. }\end{array}$ \\
\hline \multicolumn{4}{|c|}{ Planície Fluvial } \\
\hline $\begin{array}{l}\text { Drenagem imperfeita dos } \\
\text { solos; áreas alagáveis e } \\
\text { sujeitas a inundações; tipo de } \\
\text { solos: neossolos e gleissolos. }\end{array}$ & $\begin{array}{lr}\text { Pecuária } & \text { semi-extensiva } \\
\text { mista; mineração (areia), leito } \\
\text { e margem de rio; ocupação } \\
\text { humana nas margens dos } \\
\text { rios; pesca amadora de } \\
\text { subsistência. }\end{array}$ & $\begin{array}{l}\text { Degradação da mata ciliar; } \\
\text { assoreamento do leito fluvial; } \\
\text { poluição hídrica por esgotos } \\
\text { domésticos e agrotóxicos; } \\
\text { impacto de mineração de } \\
\text { areia; erosão das margens dos } \\
\text { rios. }\end{array}$ & $\begin{array}{l}\text { Recursos } \\
\text { abundantes; }\end{array}$ \\
\hline
\end{tabular}




\section{Areas Medianamente Frágeis}

\begin{tabular}{|c|c|c|c|}
\hline \multicolumn{4}{|c|}{ Serra de São Miguel } \\
\hline Limitações & Ocup. e Uso da Terra & Problemas & Potencial \\
\hline $\begin{array}{l}\text { Declividade; afloramento } \\
\text { rochas; mantos de alteração; } \\
\text { predomínio dos solos } \\
\text { argissolos vermelho-amarelos }\end{array}$ & $\begin{array}{l}\text { Capoeiras e capoeirinhas e } \\
\text { capoeirões; moradias; } \\
\text { pedreira (brita); loteamentos } \\
\text { irregulares. }\end{array}$ & $\begin{array}{l}\text { Desmatamentos; erosão e } \\
\text { movimentos de massa; área } \\
\text { de ocupação desordenada; } \\
\text { lixo; lançamento de esgotos } \\
\text { na rede fluvial. }\end{array}$ & $\begin{array}{l}\text { Mineração controlada; área } \\
\text { de preservação permanente } \\
\text { acima de } 30 \% \text {; educação } \\
\text { ambiental. }\end{array}$ \\
\hline \multicolumn{4}{|c|}{ Planalto de Biguaçu/ Três Riachos } \\
\hline $\begin{array}{l}\text { Cambissolos flúvicos e } \\
\text { háplicos; argissolos } \\
\text { vermelho-amarelos } \\
\text { distróficos; declividade de } \\
12 \% \text { a > 30\%. }\end{array}$ & 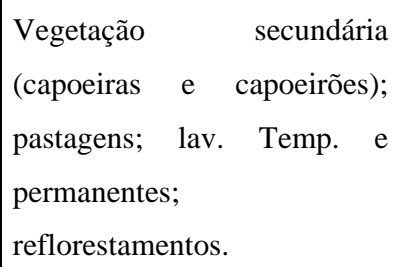 & $\begin{array}{l}\text { Uso abusivo de agrotóxicos; } \\
\text { erosão em áreas degradadas } \\
\text { pelo homem; exploração } \\
\text { mineral de saibro; ausência } \\
\text { de mata ciliar. }\end{array}$ & $\begin{array}{lr}\text { Mineração } & \text { controlada; } \\
\text { educação } & \text { ambiental; } \\
\text { ecoturismo, lazer em parques } & \\
\text { aquáticos. } & \end{array}$ \\
\hline
\end{tabular}

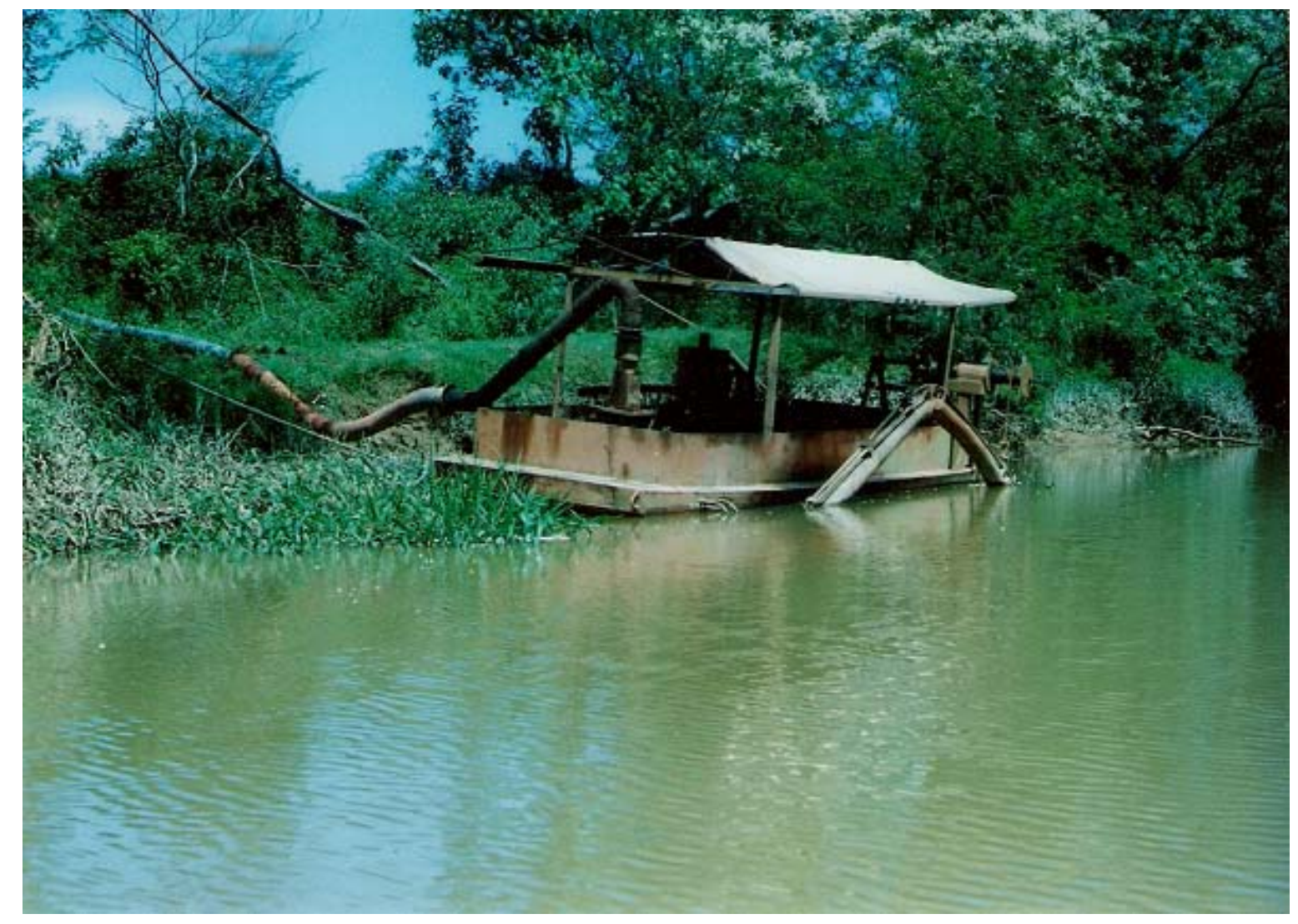

Figura 43- Balsa de sucção de água, utilizada para a extração de areia, na marguem direita do Rio Biguaçu, no município de Biguaçu-SC. (Foto: Ivanete Nardi, fevereiro/2006). 
Quadro 3 - Áreas Medianamente Estáveis da Bacia do Rio Biguaçu-SC.

\begin{tabular}{|c|c|c|c|c|}
\hline \multicolumn{5}{|c|}{ Áreas Medianamente Estáveis } \\
\hline \multicolumn{5}{|c|}{ Planalto de Cimeira } \\
\hline Limitações & & Ocup. e uso da terra & Problemas & Potencial \\
\hline $\begin{array}{l}\text { Declividade; } \\
\text { cambissolos } \\
\text { argissolos } \\
\text { amarelos. }\end{array}$ & $\begin{array}{r}\text { solos } \\
\text { flúvicos e } \\
\text { vermelho- }\end{array}$ & $\begin{array}{l}\text { Vegetação } \\
\text { (capoeirões); pecundária } \\
\text { campos de altitudes; } \\
\text { reflorestamentos; }\end{array}$ & $\begin{array}{l}\text { Terracetes em áreas de } \\
\text { pastagens; presença de } \\
\text { espécies exóticas na RPPN. }\end{array}$ & $\begin{array}{l}\text { Unidade de conservação } \\
\text { (reserva de mata atlântica); } \\
\text { manacial rio farias; educação } \\
\text { ambiental; visitação pública } \\
\text { da RPPN. }\end{array}$ \\
\hline
\end{tabular}

As áreas frágeis são aquelas localizadas na área litorânea da cidade de Biguaçu e nas planícies fluviais nos municípios de Antônio Carlos e Biguaçu. É na baía norte, defronte a Ilha de Santa Catarina, o local onde o rio Biguaçu desemboca suas águas. È uma região frágil do ponto de vista ambiental, sendo um local de transição do sistema fluvial e ambiente marinho. O rápido crescimento da população e a ocupação desordenada no distrito-sede de Biguaçu, tem agravado o quadro de degradação ambiental no litoral central de Santa Catarina.

A principal vocação econômica da unidade marinha é a pesca. De acordo com dados da Epagri de 2005, no município de Biguaçu havia 350 pescadores e 4 maricultores. No total, o setor pesqueiro envolve cerca de 1400 pessoas. Dentro da área de estudo, estão envolvidas as seguintes comunidades de pesca: Rio Caveiras, Morro da Bina e Prado.

O assoreamento da foz do rio Biguaçu prejudica as atividades dos pescadores, em período de maré baixa, pois dificulta a movimentação de embarcações, bem como, na praia do João Rosa. Além disso, a poluição recebida pelo rio Biguaçu de esgotos e lixo tem como destino final a baía norte. Recentemente em 2006, a Prefeitura Municipal de Biguaçu, construiu na praia do João Rosa um trapiche, visando facilitar o embarque e desembarque dos pescadores.

Na planície fluvial os tipos de solos presentes são os cambissolos e os gleissolos e os neossolos. O uso da terra dominante é as pastagens. Na agricultura destaca-se o cultivo de hortaliças, grama e arroz. A mineração de areia no leito do rio Biguaçu contribui para o fornecimento de sedimentos para a corrente rumo à foz. Um dos problemas mais comuns na 
bacia é a ausência da vegetação nas margens dos canais fluviais, notadamente no médio e baixo curso dos rios Biguaçu, Saudade, Três Riachos, do Louro, Farias e Rachadel. Na maioria das vezes, as pastagens e os cultivos da terra não respeitam as áreas de APP dos rios. Tal prática contribui para a erosão das margens e o carreamento de sedimentos para o sistema de drenagem, provocando o seu assoreamento. A poluição por esgotos ocorre em grande escala nos cursos d’águas, comprometendo a qualidade das águas dos rios, limitando o uso múltiplo desse recurso natural.

A Serra de São Miguel está localizada próximo ao litoral do município de Biguaçu. Nessa unidade geomorfológica predomina a cobertura vegetal de remanscentes de mata atlântica (capoeiras e capoeirões). Em alguns setores das encostas aparecem declividades acentuadas e há presença de espessos mantos de alteração. O solo dominante é o argissolos vermelho-amarelos. Nessa unidade, está presente uma mineração de brita em atividade.

A ocupação desordenada da cidade de Biguaçu tem favorecido a instalação de novas moradias em locais de perigo à ocorrência de escorregamentos na Serra de São Miguel. No bairro do Prado, há problemas de desmatamentos, falta de saneamento básico e lixo.

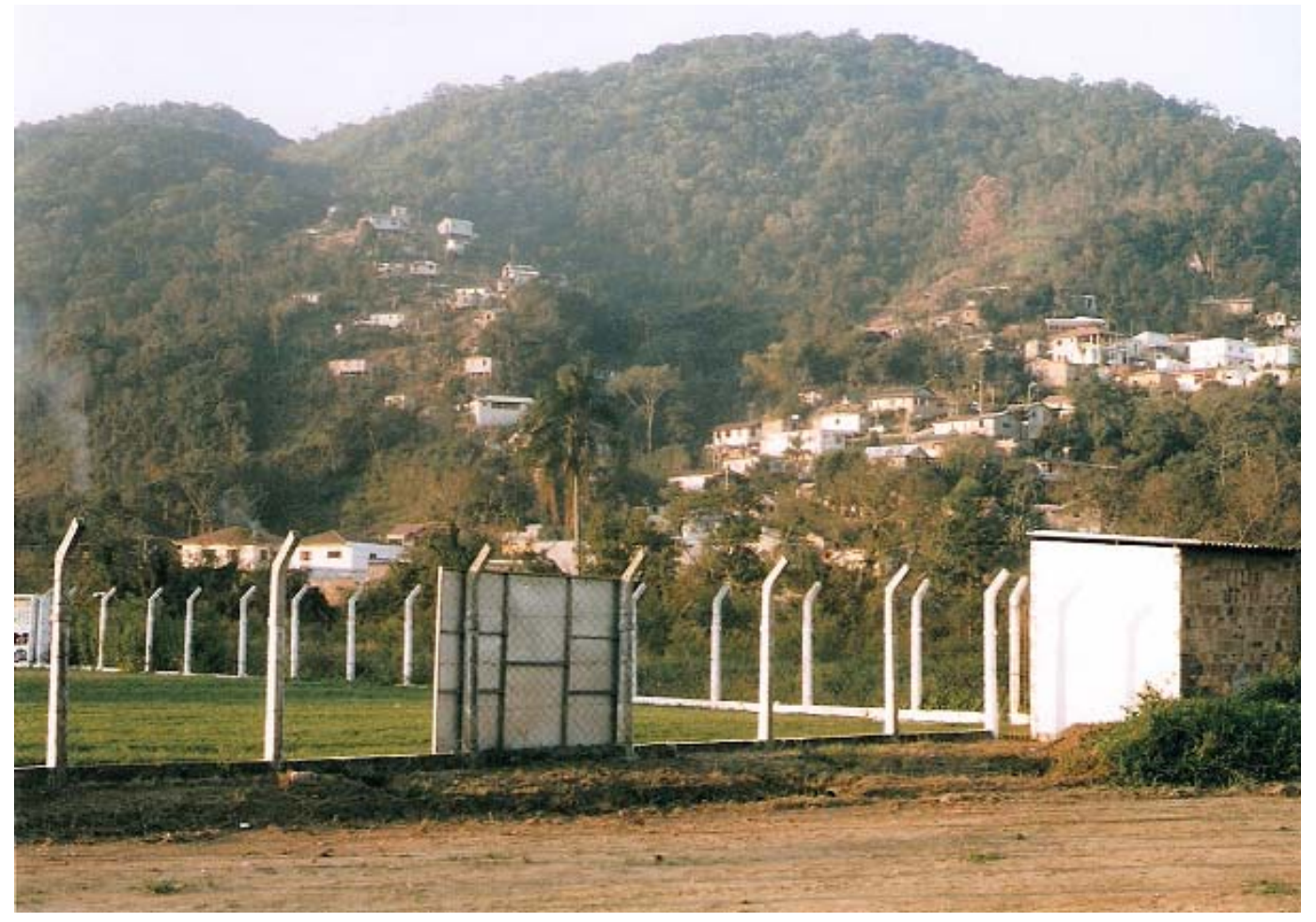

Figura 44- Ocupação humana na encosta do morro no bairro do Prado, na Serra de São Miguel, no município de Biguaçu - SC. ( Foto: Vicente R. Silva, julho/2006). 
A unidade geomorfológica Planalto de Biguaçu/Três Riachos é a maior unidade da bacia. Os solos típicos são os cambissolos flúvicos e os argissolos vermelho-amarelos. As declividades variam de 12 a 30\%. Na paisagem predominam as capoeiras e os capoeirões. No uso da terra as pastagens se destacam, associadas às lavouras temporárias e permanentes. Na silvicultura é comum a presença de talhões de eucaliptos. Na mineração, o saibro é utilizado na construção civil e na produção de grama nos dois municípios.

Cenários Tendencial e Desejado

Quadro 4 Cenários tendencial e desejado da bacia do Rio Biguaçu-SC

\begin{tabular}{|c|c|c|}
\hline \multicolumn{3}{|c|}{ Quadro de Cenários } \\
\hline Área & Cenário tendencial & Cenário desejado \\
\hline Marinha e praia & $\begin{array}{l}\text { Diminuição de recursos pesqueiros; } \\
\text { diminuição da pesca amadora; aumento } \\
\text { da poluição por esgotos domésticos na } \\
\text { baía norte; aumento da sedimentação na } \\
\text { foz do rio Biguaçu e áreas adjacentes } \\
\text { (praia de João Rosa). }\end{array}$ & $\begin{array}{l}\text { Coleta e tratamento de esgotos; pesca } \\
\text { profissional e amadora controlada; flora } \\
\text { e fauna conservada; atividades } \\
\text { educativas permanentes realizadas; } \\
\text { ambiente litorâneo monitorado, } \\
\text { conforme prevê o plano Nacional de } \\
\text { Gerenciamento Costeiro. }\end{array}$ \\
\hline $\begin{array}{l}\text { Planície flúvio-marinha } \\
\text { (manguezal) }\end{array}$ & $\begin{array}{l}\text { Uso inadequado do manguezal; poluição } \\
\text { hídrica por esgotos domésticos sem } \\
\text { controle; lixo, perda de diversidade } \\
\text { biológica do estuário do rio Biguaçu e } \\
\text { manguezal; aumento da ocupação } \\
\text { humana nas áreas de APP do rio } \\
\text { Biguaçu. }\end{array}$ & $\begin{array}{l}\text { Atividades de educação ambiental } \\
\text { permanentes; patrimônio paisagístico } \\
\text { conservado, protegido e recuperado; } \\
\text { flora e fauna manejadas adequadamente; } \\
\text { recuperação do ecossistema manguezal } \\
\text { e da mata ciliar do rio Biguaçu e } \\
\text { tributários; atividades humanas } \\
\text { planícies ribeirinhas controladas; } \\
\text { qualidade dos recursos hídricos } \\
\text { controlada; coleta e tratamento de } \\
\text { efluentes domésticos das cidades de } \\
\text { Antônio Carlos e Biguaçu; turismo de } \\
\text { observação do manguezal e do rio } \\
\text { Biguaçu. }\end{array}$ \\
\hline
\end{tabular}




\begin{tabular}{|c|c|c|}
\hline Planície fluvial & $\begin{array}{l}\text { Aumento da demanda por recursos } \\
\text { hídricos (irrigação de hortaliças e } \\
\text { grama); aumento da poluição hídrica } \\
\text { por esgotos domésticos e resíduos de } \\
\text { agrotóxicos; perda da qualidade de água } \\
\text { superficiais; diminuição da pesca; } \\
\text { assoreamento do leito fluvial e da foz do } \\
\text { rio Biguaçu; impacto da mineração de } \\
\text { areia (erosão das margens e aumento } \\
\text { dos sedimentos transportados pela } \\
\text { corrente). }\end{array}$ & $\begin{array}{l}\text { Bacia hidrográfica manejada } \\
\text { integralmente; monitoramento da } \\
\text { qualidade das águas permanentemente } \\
\text { realizado; controle e fiscalização do uso } \\
\text { de agrotóxicos; saneamento ambiental } \\
\text { realizado; atividade de mineração } \\
\text { monitoradas e controladas. }\end{array}$ \\
\hline Serra de São Miguel & $\begin{array}{l}\text { Aumento da concentração humana; } \\
\text { aumento de desmatamento; incremento } \\
\text { da mineração de brita (pedreira); } \\
\text { aumento das doenças de veiculação } \\
\text { hídrica; corpos de água contaminados } \\
\text { por resíduos sólidos e esgotos } \\
\text { domésticos, solos erodidos, áreas de } \\
\text { riscos ambientais a movimentos de } \\
\text { massa. }\end{array}$ & $\begin{array}{l}\text { Atividades de desmatamentos } \\
\text { controladas; controle da ocupação do } \\
\text { solo no bairro do Prado e outros em } \\
\text { Biguaçu; saneamento ambiental } \\
\text { realizado; abastecimento de água em } \\
\text { áreas de morros; coleta de lixo sólido } \\
\text { adequada; coleta de material reciclado } \\
\text { (coleta seletiva); retirada de residências } \\
\text { em áreas de riscos ambientais; } \\
\text { atividades de exploração mineral } \\
\text { monitoradas e controladas. }\end{array}$ \\
\hline Planalto de Biguaçu/Três Riachos & $\begin{array}{l}\text { Aumento do uso de agrotóxicos; } \\
\text { aumento da exploração mineral de } \\
\text { saibro; aumento de áreas degradadas } \\
\text { (área de empréstimo); aumento de áreas } \\
\text { de riscos ambientais por abandono de } \\
\text { antigas saibreiras; aumento da erosão } \\
\text { dos solos pela agricultura e pecuária; } \\
\text { lançamento de águas servidas de } \\
\text { esgotos e escrementos animais nos } \\
\text { cursos d'água. }\end{array}$ & $\begin{array}{l}\text { Orientação e controle do uso abusivo de } \\
\text { agrotóxicos; controle e fiscalização } \\
\text { ambiental pela Fatma e DNPM de áreas } \\
\text { de mineração de areia e saibro; } \\
\text { recomposição da mata ciliar nos rios da } \\
\text { bacia do rio Biguaçu; Na produção } \\
\text { agrícola uso de técnicas de conservação } \\
\text { de solos; destinação adequada de } \\
\text { dejetos e lixo (construção de fossas e } \\
\text { sumidouros). }\end{array}$ \\
\hline Planalto de Cimeira & Aumento da cobertura vegetal natural . & $\begin{array}{l}\text { Implantação de zona de amortecimento } \\
\text { ao redor da RPPN Caraguatá; abertura } \\
\text { da U. C. para visitação pública; projetos } \\
\text { de educação ambiental junto a } \\
\text { comunidade local do município de } \\
\text { Antônio Carlos. }\end{array}$ \\
\hline
\end{tabular}


A presença da colônia de pescadores de Biguaçu (Z-23), representa que a pesca é principal fonte de renda de uma parcela da população do município. O agravamento do quadro de degradação da qualidade das águas do rio Biguaçu contribui na diminuição dos recursos pesqueiros na baía norte. Atualmente não há pesca profissional no rio Biguaçu. Esse rio recebe toda a carga de poluição de esgoto, principalmente no trecho entre a BR-101 e a foz. Nas áreas urbanas dos dois municípios, são necessárias obras de infraestrutura no sistema de tratamento de esgotos domiciliar.

No manguezal deve-se realizar ações no combate à degradação desse ecossistema, causada por desmatamentos, aterros e lixo. As atividades de educação ambiental devem ser permanentes, a fim de sensibilizar e conscientizar as comunidades em geral do papel da natureza na manuntenção da qualidade de vida das sociedades humanas. A recuperação ambiental do manguezal trará benefícios econômicos e sociais à atividade de pesca no município.

Nas planícies dos rios da bacia desenvolve-se a exploração econômica das terras. O cenário tendencial é de aumento da demanda por água para irrigação na produção de hortaliças e de grama. No entanto, as águas superficiais estão cada vez mais comprometidas pela poluição hídrica por esgotos e de resíduos, pelo uso abusivo de agrotóxicos nas lavouras comerciais.

No cenário desejado, é preciso um projeto de recuperação ambiental para toda a bacia hidrográfica, com a participação de todos os seguimentos envolvidos, visando o bem-estar da sociedade.

A ocupação humana na Serra de São Miguel intensificou nos últimos anos, como também o avanço da frente da mineração de brita. A ocupação irregular de novas moradias agrava os problemas de desmatamentos, lançamento de águas servidas na rede fuvial e lixo. A Prefeitura Municipal de Biguaçu deve efetivamente cumprir o seu poder no controle do uso do solo urbano, através dos instrumentos legais que dispõem, como o Plano Diretor. É preciso promover a melhoria no controle e na fiscalização por parte do DNPM, IBAMA e FATMA. A falta de estrutura e de recursos humanos nos órgãos de proteção do meio ambiente acaba agravando a impunidade em crimes ambientais. 
Diretrizes Gerais e Específicas

Diretrizes Gerais

Quadro 5 - Diretrizes gerais e específicas para a bacia do Rio Biguaçu-SC.

\begin{tabular}{|c|c|c|c|c|}
\hline \multirow[b]{2}{*}{ Proposições } & \multicolumn{4}{|c|}{ Intrumento } \\
\hline & Técnico & Legal & Institucional & Econômico-financeiro \\
\hline $\begin{array}{l}\text { Implantar sistema de coleta e } \\
\text { tratamento de esgotos para as } \\
\text { áreas urbanas }\end{array}$ & Projeto & & $\begin{array}{l}\text { Ministério das Cidades; } \\
\text { governo estadual, Prefeituras } \\
\text { Municipais; Casan. }\end{array}$ & 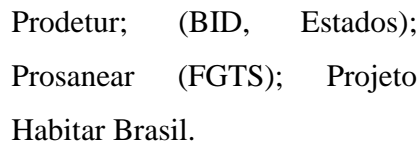 \\
\hline $\begin{array}{l}\text { Desenvolver ações de } \\
\text { recuperação de APP’s }\end{array}$ & & & $\begin{array}{l}\text { Ibama, Fatma, Secretaria de } \\
\text { agricultura, meio ambiente das } \\
\text { prefeituras; Apremabi. }\end{array}$ & 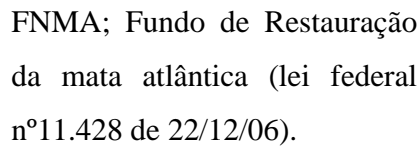 \\
\hline $\begin{array}{l}\text { Estimular a formação de } \\
\text { comitê da bacia do rio } \\
\text { Biguaçu }\end{array}$ & & & $\begin{array}{l}\text { Governo de Santa Catarina,; } \\
\text { ANA. }\end{array}$ & OGU, FNMA \\
\hline $\begin{array}{l}\text { Enquadar os corpos d’água } \\
\text { segundo a legislação vigente. }\end{array}$ & & & $\begin{array}{l}\text { Secretária estadual de recursos } \\
\text { hídricos de Santa Catarina; } \\
\text { comitê de bacias, SRH; ANA. }\end{array}$ & \\
\hline $\begin{array}{l}\text { Promover a estruturação, } \\
\text { melhoria e integração dos } \\
\text { serviços de limpeza pública } \\
\text { nos dois municípios. }\end{array}$ & & & $\begin{array}{l}\text { Prefeituas municipais; } \\
\text { governos de Santa Catarina; } \\
\text { Sedu/PR. }\end{array}$ & Progest/CEF \\
\hline $\begin{array}{l}\text { Promover o desenvolvimento } \\
\text { do ecoturismo na região. }\end{array}$ & Projeto & & $\begin{array}{l}\text { Santur, prefeituras municipais, } \\
\text { Embratur. }\end{array}$ & $\begin{array}{l}\text { FNMA; Prodetur; PNMT; } \\
\text { orçamentos municipais. }\end{array}$ \\
\hline $\begin{array}{l}\text { Promover a educação } \\
\text { ambiental em todos os níveis }\end{array}$ & Projeto & & $\begin{array}{l}\text { Prefeituras de Antônio Carlos e } \\
\text { Biguaçu; Secretária Estadual } \\
\text { de Educação; Epagri. }\end{array}$ & \\
\hline
\end{tabular}

A principal meta é dotar de infraestrutura urbana os municípios de Antônio Carlos e Biguaçu, no setor de saneamento básico de qualidade. Outras ações, dizem respeito a recomposição da vegetação marginal dos rios, com o plantio de espécies nativas, em áreas de APP’s. A crescente demanda por água para diferentes usos, já justifica a criação do comitê da bacia do rio Biguaçu. Além disso, deve-se promover o enquadramento dos cursos d’água da 
bacia.Os serviços de coleta e limpeza pública dos dois municípios devem ser melhorados e a implementação de campanhas de orientação da população sobre a questão do lixo.

O turismo é parcialmente explorado no município de Antônio Carlos, como por exemplo, na realização das tradicionais festas do colono (área central) e da hortaliça, na comunidade de Rachadel. Atualmente Antônio Carlos possui seis parques aquáticos, com grande fluxo de pessoas no verão. Há outras potencialidades ainda não exploradas. Em Biguaçu há a tradicional Bigfest no mês de maio, porém, o turismo não possui destaque nessa atividade. A navegação fluvial não é explorada, apesar das belezas naturais do vale do rio Biguaçu.

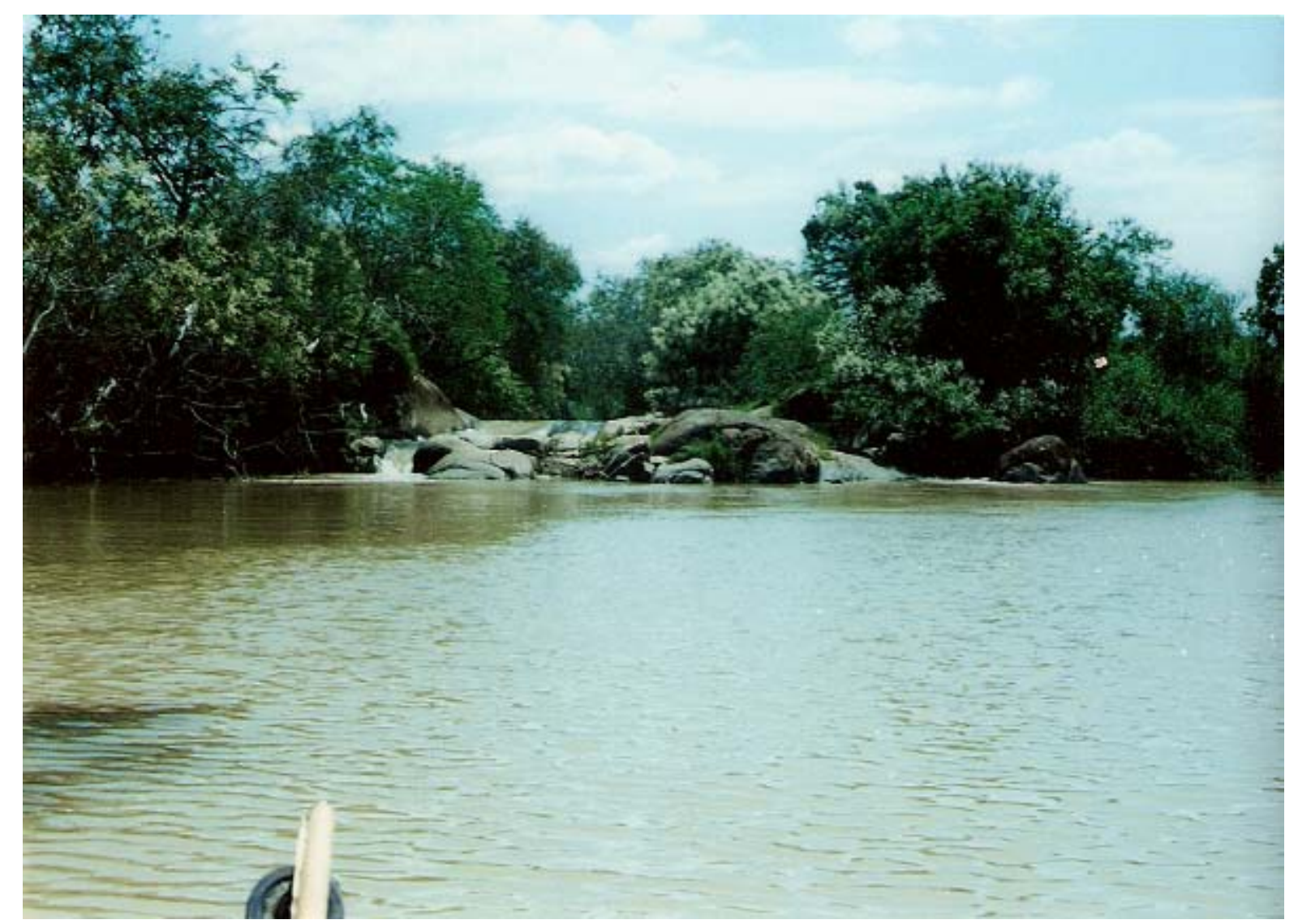

Figura 45 - Rio Três Riachos, próximo à foz no Rio Biguaçu, que apresenta corredeiras e mata ciliar, no município de Biguaçu-SC.( Foto: Ivanete Nardi, fevereiro/2006). 


\section{Diretrizes Específicas}

Quadro 6 - Diretrizes específicas para áreas frágeis - Marinha

\begin{tabular}{|c|c|c|c|c|}
\hline \multicolumn{5}{|c|}{ Áreas Frágeis } \\
\hline & & & & \\
\hline \multirow{2}{*}{ Proposições } & \multicolumn{4}{|c|}{ Intrumento } \\
\hline & Técnico & Legal & Institucional & Econômico-financeiro \\
\hline $\begin{array}{l}\text { Desenvolver ações de } \\
\text { monitoramento/fiscaliz } \\
\text { ação de fontes poluição } \\
\text { urbana e industrial }\end{array}$ & Estudos técnicos & & $\begin{array}{l}\text { Ibama, Fatma, } \\
\text { prefeituras municipais. }\end{array}$ & \\
\hline $\begin{array}{l}\text { Recuperação ambiental } \\
\text { e sócio-econômica da } \\
\text { orla maritíma da baía } \\
\text { norte em Biguaçu. }\end{array}$ & Projeto & & $\begin{array}{l}\text { Prefeitura Municipal } \\
\text { de Biguaçu; Secretaria } \\
\text { de Desenvolvimento } \\
\text { Regional de São José } \\
\text { (estadual). }\end{array}$ & $\begin{array}{l}\text { Projeto Habitar } \\
\text { Brasil/BID }\end{array}$ \\
\hline $\begin{array}{l}\text { Desenvolver } \begin{array}{l}\text { ações } \\
\text { permanentes }\end{array} \\
\text { limpeza da praia } \\
\text { João de } \\
\text { Biguaçu. }\end{array}$ & & & $\begin{array}{l}\text { Prefeitura Municipal } \\
\text { de Biguaçu; Secretaria } \\
\text { de Desenvolvimento } \\
\text { Regional de São José; } \\
\text { Apremabi. }\end{array}$ & \\
\hline
\end{tabular}

Quadro 7 - Diretrizes específicas para áreas frágeias - Manguezal

\begin{tabular}{|c|c|c|c|c|}
\hline \multicolumn{5}{|c|}{ Áreas Frágeis } \\
\hline \multicolumn{5}{|c|}{ Manguezal } \\
\hline \multirow[b]{2}{*}{ Proposições } & \multicolumn{4}{|c|}{ Intrumento } \\
\hline & Técnico & Legal & Institucional & $\begin{array}{l}\text { Econômico- } \\
\text { Financeiro }\end{array}$ \\
\hline $\begin{array}{l}\text { Promover a recuperação } \\
\text { ambiental do manguezal do rio } \\
\text { Biguaçu }\end{array}$ & Estudos técnicos & & $\begin{array}{l}\text { Fatma, Ibama, prefeitura } \\
\text { municipal de Biguaçu, } \\
\text { universidades, Apremabi }\end{array}$ & FNMA \\
\hline
\end{tabular}


Quadro 8 - Diretrizes específicas para áreas frágeis - Planície Fluvial

\begin{tabular}{|c|c|c|c|c|}
\hline \multicolumn{5}{|c|}{ Áreas Frágeis } \\
\hline \multicolumn{5}{|c|}{ Planície Fluvial } \\
\hline \multirow[b]{2}{*}{ Proposições } & \multicolumn{4}{|c|}{ Intrumento } \\
\hline & Técnico & Legal & Institucional & Econômico-Financeiro \\
\hline $\begin{array}{l}\text { Intensificar a fiscalização e } \\
\text { controle das atividades de } \\
\text { mineração de areia e saibro. }\end{array}$ & $\begin{array}{l}\text { Cadastramento } \\
\text { das fontes de } \\
\text { lavras }\end{array}$ & & DNPM; Fatma. & \\
\hline $\begin{array}{l}\text { Desenvolver } \\
\text { prioritariamente ações } \\
\text { voltadas para recuperação e } \\
\text { auto-recuperação de áreas } \\
\text { de APP's. }\end{array}$ & & & $\begin{array}{l}\text { Fatma.; Ibama; Prefeitura } \\
\text { municipal de Antônio Carlos } \\
\text { e Biguaçu. }\end{array}$ & $\begin{array}{l}\text { Fundo de Restauração de } \\
\text { mata atlântica }\end{array}$ \\
\hline $\begin{array}{lr}\text { Estimular } & \text { pecuária } \\
\text { agricultura } & \text { de } \\
\text { impacto } & \text { baixo } \\
\text { (agricultura agroecológica). }\end{array}$ & & & & $\begin{array}{l}\text { Secretaria Estadual de } \\
\text { Agricultura de Santa } \\
\text { Catarina; Epagri, prefeituras } \\
\text { municipais. }\end{array}$ \\
\hline $\begin{array}{l}\text { Avaliar a capacidade de } \\
\text { carga do ecossistema para } \\
\text { fins de implantação de } \\
\text { projeto de ecoturismo. }\end{array}$ & Estudos & & $\begin{array}{l}\text { Santur; Embratur; Prefeituras } \\
\text { Municipais. }\end{array}$ & \\
\hline $\begin{array}{l}\text { Estimular e fiscalizar o uso } \\
\text { racional de agrotóxicos na } \\
\text { meio rural. }\end{array}$ & & & $\begin{array}{l}\text { Epagri; Secretaria de } \\
\text { agricultura das prefeituras } \\
\text { municipais. }\end{array}$ & \\
\hline
\end{tabular}


Quadro 9 - Diretrizes específicas para áreas medianamente frágeias - Serra de São Miguel

\begin{tabular}{|c|c|c|c|c|}
\hline \multicolumn{5}{|c|}{ Áreas Medianamente Frágeis } \\
\hline \multicolumn{5}{|c|}{ Serra de São Miguel } \\
\hline \multirow[b]{2}{*}{ Proposições } & \multicolumn{4}{|c|}{ Intrumento } \\
\hline & Técnico & Legal & Institucional & $\begin{array}{l}\text { Econômico- } \\
\text { Financeiro }\end{array}$ \\
\hline $\begin{array}{l}\text { Promover a retirada de } \\
\text { famílias em moradias em } \\
\text { áreas de riscos ambientais. }\end{array}$ & & $\begin{array}{l}\text { Código Florestal do } \\
\text { Brasil (1965); Plano } \\
\text { Diretor de Biguaçu (em } \\
\text { revisão) }\end{array}$ & $\begin{array}{l}\text { Prefeitura Municipal } \\
\text { de Biguaçu; }\end{array}$ & \\
\hline $\begin{array}{llrr}\text { Promover } & \text { a } & \text { recuperação } \\
\text { ambiental } & \text { de } & \text { áreas } \\
\text { desmatadas. } & & \\
\end{array}$ & Estudos & & & \\
\hline $\begin{array}{lccc}\text { Promover } & \text { ações } & \text { visando a } \\
\text { adequação } & \text { da } & \text { coleta } & \text { de } \\
\text { esgotos } & \text { nos } & \text { bairros } \\
\text { populares. } & & \\
\end{array}$ & & & & \\
\hline $\begin{array}{llll}\text { Fiscalizar e proibir } & \text { a } \\
\text { construção } & \text { de } & \text { novas } \\
\text { moradias em locais } & \text { de } \\
\text { declividade acentuada com } & \\
\text { riscos ambientais } & \text { a } \\
\text { movimentos de massa } & \text { e } \\
\text { áreas marginais aos rios. }\end{array}$ & & Plano diretor de Biguaçu; & $\begin{array}{l}\text { Prefeitura Municipal } \\
\text { de Biguaçu; Polícia } \\
\text { Ambiental; Fatma. }\end{array}$ & \\
\hline
\end{tabular}


Quadro 10 - Diretrizes específicas para áreas medianamente estáveis - Planalto de Biguaçú/ Três Riachos

\begin{tabular}{|c|c|c|c|c|}
\hline \multicolumn{5}{|c|}{ Áreas Medianamente Estáveis } \\
\hline \multicolumn{5}{|c|}{ Planalto de Biguaçu/Três Riachos } \\
\hline \multirow[b]{2}{*}{ Proposições } & \multicolumn{4}{|c|}{ Intrumento } \\
\hline & Técnico & Legal & Institucional & $\begin{array}{l}\text { Econômico- } \\
\text { Financeiro }\end{array}$ \\
\hline $\begin{array}{l}\text { Incentivar a agricultura } \\
\text { agroecológica } \\
\text { hortaliças e frutas. }\end{array}$ & Projeto & & $\begin{array}{l}\text { Epagri; Secretaria } \\
\text { municipais de } \\
\text { agricultura de Antônio } \\
\text { Carlos e Biguaçu. }\end{array}$ & \\
\hline $\begin{array}{l}\text { Promover ações visando a } \\
\text { recuperação de áreas de } \\
\text { APP's. }\end{array}$ & Projeto & & $\begin{array}{l}\text { Prefeituras municipais; } \\
\text { Fatma; Epagri. }\end{array}$ & $\begin{array}{l}\text { Fundo de Restauração } \\
\text { de mata atlântica (lei } \\
\text { federal } n^{\circ} 11.428 \\
(22 / 12 / 06) \text {. }\end{array}$ \\
\hline $\begin{array}{l}\text { Incentivar e fomentar o } \\
\text { turismo rural. }\end{array}$ & Projeto & & $\begin{array}{l}\text { Santur; } \quad \text { Embratur; } \\
\text { Prefeituras. }\end{array}$ & FNMA \\
\hline $\begin{array}{l}\text { Controle e fiscalização de } \\
\text { áreas de empréstimo. }\end{array}$ & & & DNPM, Fatma. & \\
\hline $\begin{array}{l}\text { Educação ambiental nas } \\
\text { comunidades rurais. }\end{array}$ & Projeto & & $\begin{array}{l}\text { Secretarias municipais } \\
\text { de educação; Epagri. }\end{array}$ & \\
\hline $\begin{array}{lr}\text { Implantar } & \text { nas } \\
\text { propriedades rurais } \\
\text { tratamento adequado de } \\
\text { esgotos e lixo. }\end{array}$ & Projeto & & $\begin{array}{l}\text { Prefeituras municipais; } \\
\text { Epagri. }\end{array}$ & \\
\hline
\end{tabular}


Quadro 11 - Diretrizes específicas para áreas medianamente estáveis- Planalto de Cimeira

\begin{tabular}{|c|c|c|c|c|}
\hline \multicolumn{5}{|c|}{ Áreas Medianamente Estáveis } \\
\hline \multicolumn{5}{|c|}{ Planalto de Cimeira } \\
\hline \multirow{2}{*}{ Proposições } & \multicolumn{4}{|c|}{ Intrumento } \\
\hline & Técnico & Legal & Institucional & $\begin{array}{l}\text { Econômico- } \\
\text { Financeiro }\end{array}$ \\
\hline $\begin{array}{l}\text { Promover a proteção } \\
\text { de fontes naturais de } \\
\text { águas e implantar o } \\
\text { saneamento básico de } \\
\text { esgoto e lixo. }\end{array}$ & Projeto & & $\begin{array}{l}\text { Epagri; Prefeituras } \\
\text { municipais. }\end{array}$ & \\
\hline $\begin{array}{l}\text { Incentivar e fomentar o } \\
\text { turismo rural. }\end{array}$ & Projeto & & $\begin{array}{l}\text { Santur, Prefeituras } \\
\text { municipais. }\end{array}$ & \\
\hline $\begin{array}{l}\text { Ampliar a visitação } \\
\text { pública e educação } \\
\text { ambiental na RPPN } \\
\text { Caraguatá . }\end{array}$ & Projeto & & $\begin{array}{lr}\text { Administração } & \text { da } \\
\text { unidade } & \text { de } \\
\text { conservação; } & \text { Fatma; } \\
\text { Ibama. } & \end{array}$ & FNMA \\
\hline
\end{tabular}




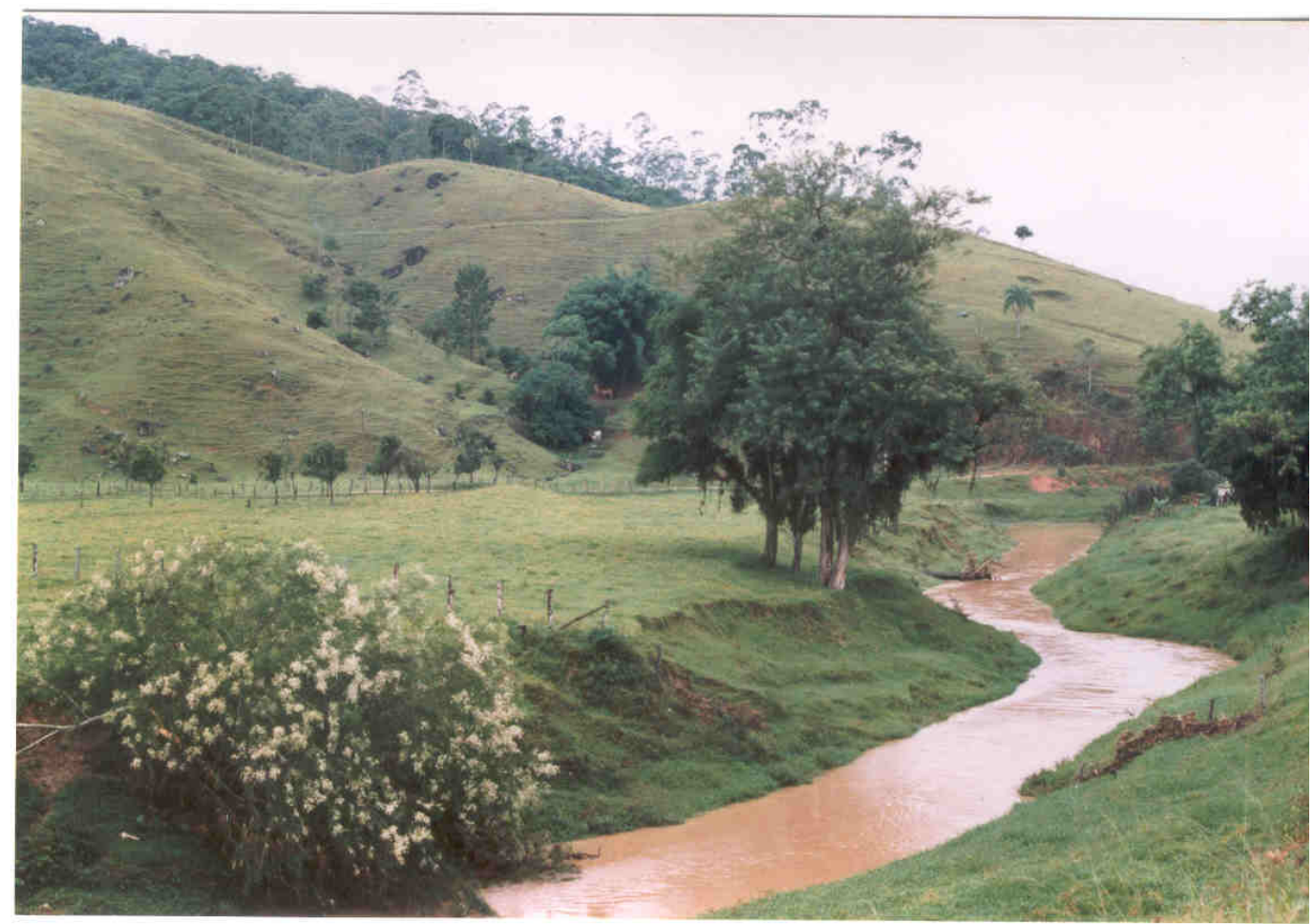

Figura 46 - Médio curso do rio Rio Biguaçu, com feições arredondadas do relevo e cicatrizes de dissecação na encosta, com atuação de erosão com retirada de finos e exposição de matacões. Uso atual é com pastagens e a ausência de mata ciliar, município de Antônio Carlos-SC. (Foto Edison Fortes, fevereiro/2005).

Foram iniciadas em outubro de 2006 as obras do projeto Beira-Rio, integrante do projeto Habitar Brasil/BID, dando início os serviços de terraplenagem e drenagem. A área da foz do Rio Biguaçu foi escolhida para desenvolver o projeto em virtude de estar sofrendo um processo de ocupação desordenada desde 1984 e de haver intensa degradação ambiental. Essas obras irão beneficiar cerca de 75 famílias. Está prevista no projeto a implantação de infraestrutura urbana e social, pois muitas casas estão em áreas de preservação permanente.

As ações prevêem a retirada de moradias dentro do manguezal, a recuperação de áreas degradadas, drenagem fluvial, rede coletora de esgotos, sistemas de tratamento de esgotos, rede de abastecimento de água, iluminação pública e pavimentação. Foi especificado no projeto, que nenhuma família fosse removida da área. Das 75 famílias cadastradas, cerca de 36 receberão novas moradias e também haverá a reforma de 13 habitações (PMB, 06/10/2006). 


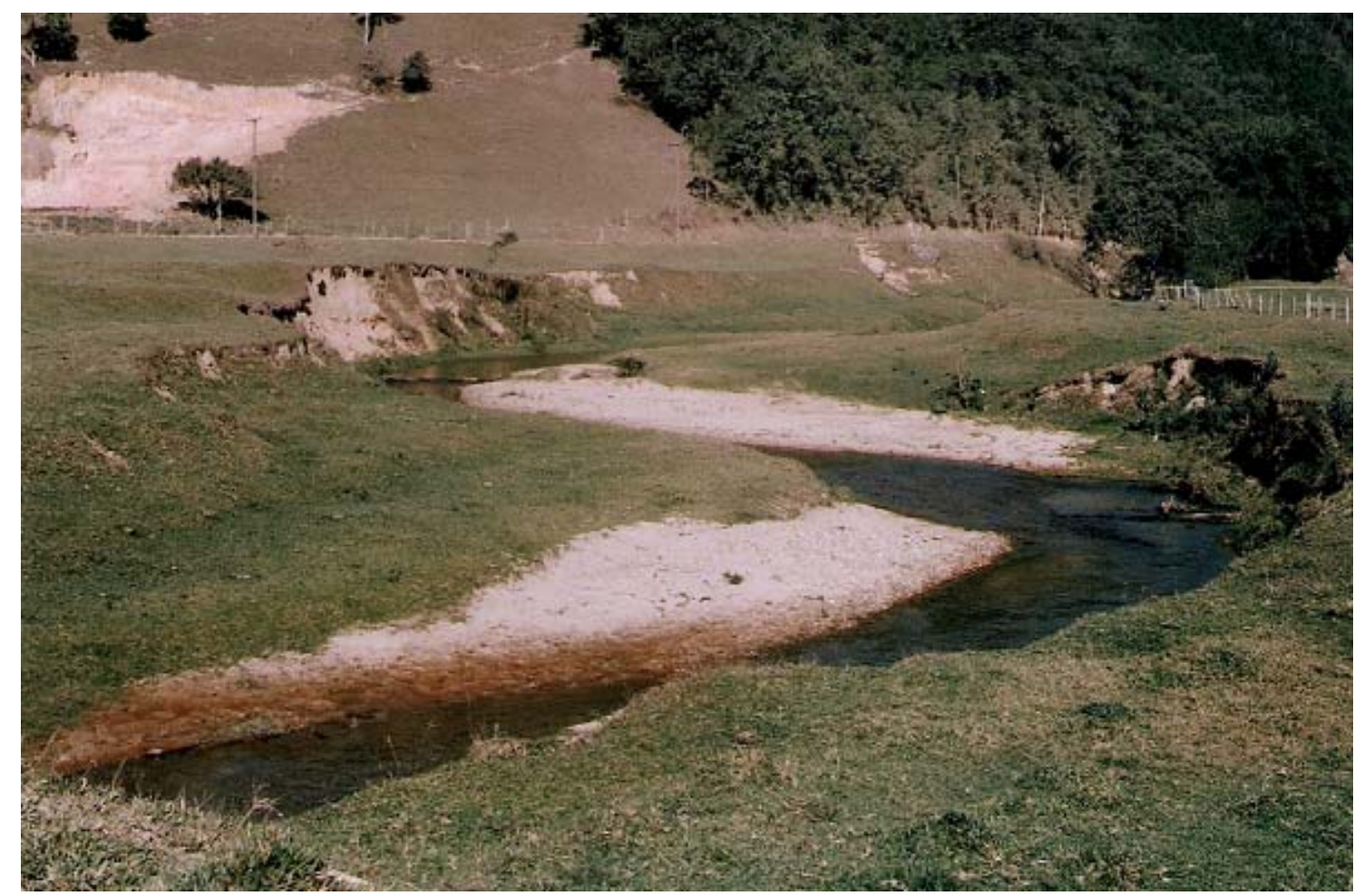

Figura 47 - Aspecto do meandrante do rio Biguaçu, com depósito de areia nas margens, na localidade Santa Maria, no município de Antônio Carlos-SC. ( Foto Vicente R. Silva, julho/2006).

Os dois municípios poderam pleitear recursos financeiros, caso tenham programa de recuperação de mata atlântica e a existência de Conselho Municipal de Meio Ambiente, do fundo de Restauração da Mata Atlântica (lei federal n 11.428 de 22/12/06).

As municipalidades em parceria com a Epagri devem incentivar e orientar os proprietários rurais, visando a prática de pecuária e agricultura de baixo impacto no ambiente. No município de Antônio Carlos há produtores que praticam a agricultura agroecológica na produção de hortaliças e de frutas, com melhor remuneração da produção agrícola.

A implementação de projeto de despoluição do Rio Biguaçu e sua revitalização econômica é que propõe o presidente da Associação pela Preservação do Meio Ambiente de Biguaçu (Apremabi), Henrique Azevedo. O ambientalista pede a criação de uma comissão formada pela Prefeitura, Câmara de Vereadores, Apremabi, Acibig, pescadores e associações comunitárias, para discutir e pensar projetos para o referido rio (Jornal Biguaçu em foco, 06/03/07). 
O poder público municipal deve zelar pelo disciplinamento da ocupação e uso do solo urbano, conforme prevê o plano diretor. No município de Biguaçu, o plano diretor de 1995 está em revisão. No município de Antônio Carlos, apesar de possuir população pequena, estimada em 7.041 habitantes (IBGE, 2006), está sendo elaborado o plano diretor.

\section{1-Mapa de Zoneamento Ambiental}

Esse mapa foi concebido atráves de combinação dos mapas temáticos: clinográfico, solos, fragilidade ambiental, ocupação e uso da terra e legislação ambiental. O mapa foi dividido em duas grandes unidades: as de zonas de restrições legais e as zonas produtivas. As zonas de restrições legais tiveram como base o Código Florestal Brasileiro (1965) e suas alterações de 1989. Assim, foram cartografados as áreas da bacia do rio Biguaçu, ocupadas com vegetação secundária (capoeirões, capoeiras e capoeirinhas). Porém, o que se observa é o domínio dos capoeirões de estágio avançado de regeneração, após intervenções humanas. É no município de Antônio Carlos onde estão as maiores áreas de remanescentes de Mata Atlântica.

Na planície marinha de Biguaçu está delimitado o reduzido manguezal do rio Biguaçu. A única Unidade de Conservação presente na área de estudo é a RPPN Caraguatá, criada em 1990. Essa unidade de conservação pertence à Unidade Geomorfológica Planalto de Cimeira, inserida quase totalmente no domínio do embasamento cristalino da Suíte Intrusiva Valsungana. Em relação aos solos, ocorre os Argissolos Vermelho-Amarelos e os Cambissolos Flúvicos.

Nas zonas produtivas predomina em termos de área a classe de lavoura temporária, com destaque na horticultura em Antônio Carlos. Essa atividade também ocorre no município de Biguaçu. Nos vales dos rios Saudade e Três Riachos, destacando o cultivo de arroz irrigado, nos Gleissolos. As lavouras permanentes de cana-de-açúcar, banana, citrus e maracujá são as mais comuns.

Segundo dados do Levantamento Agropecuário de Santa Catarina-LAC-2005 (Santa Catarina, 2005 a), do total de estabelecimentos agropecuários informantes, cerca de 35,72\% das terras do município de Biguaçu são destinadas ao uso com pastagens. No município de Antônio Carlos, as pastagens são cerca de 25,94\% do total da área dos estabelecimentos agropecuários. 
Na planície marinha de Biguaçu há pequenos polígonos de pastagens entremeados em locais de moradias no distrito-sede de Biguaçu. Em Antônio Carlos, próxima à cidade, há uma área destinada a indústrias, de 12 hectares. As indústrias são poucas e de pequeno porte, com exceção da Vonpar (refrigetantes e cerveja), considerada de grande porte, que tem cerca de 320 funcionários. Em Biguaçu, porém o setor industrial é a principal atividade econômica do município. A indústria química (material plástico) é a principal fonte de arrecadação e geração de empregos. A Prefeitura de Biguaçu pretende instalar uma nova área destinada a indústrias na localidade de Tijuquinhas, fora da bacia do rio Biguaçu (inf. verbal, abril/06).

Com relação aos morros desmatados, a grande parte está concentrada no município de Antônio Carlos. Geralmente, esses morros, com declividade < 30\%, foram desmatados no passado e atualmente são usados como pastagens. No entanto, a recomendação, conforme o zoneamento ambiental é implantação de projetos de silvicultura/agrofloresta. As áreas de morros com declividade superior a $30 \%$, devem ser destinadas a auto-recuperação, visando a recomposição da Floresta Ombrófila Densa.

As planícies fluviais dos rios Biguaçu, Ribeirão Vermelho, do Louro, da Guiomar e Rachadel são intensamente utilizadas na produção de hortaliças e grama de jardinagem, associada à utilização de pastagens. É comum em toda a bacia, área de pastagens indo até as margens dos rios, não respeitando os limites de áreas de preservação permanentes (APP), conforme prevê o Código Florestal. Esse fato, também ocorre em relação às áreas destinadas a agricultura, porém em escala menor. 


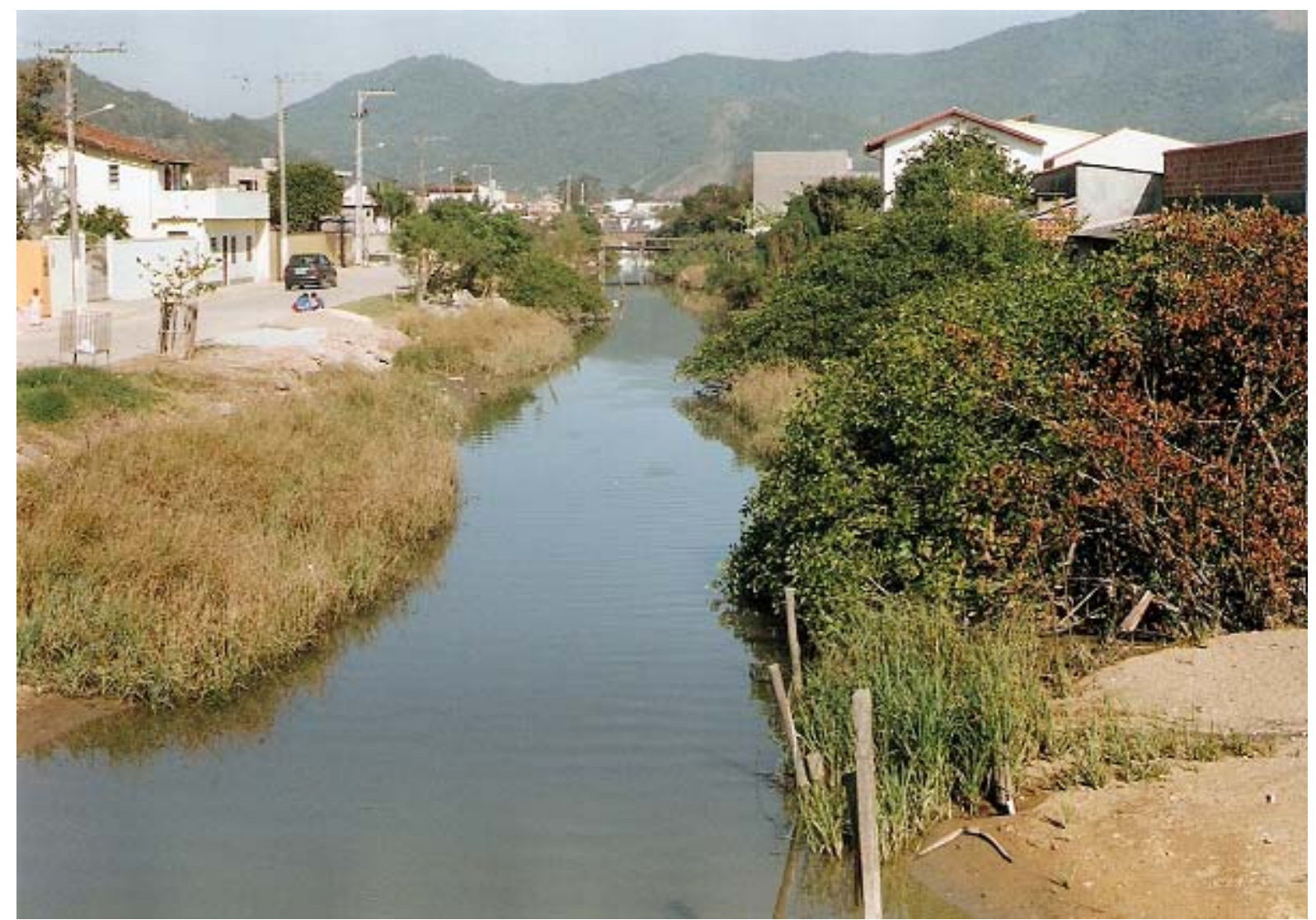

Figura 48- Ocupação humana nas margens do rio Caveiras (retificado), no bairro Saveiro, próximo à foz, na cidade de Biguaçu -SC. (Foto: Vicente R. Silva, julho/2006). 


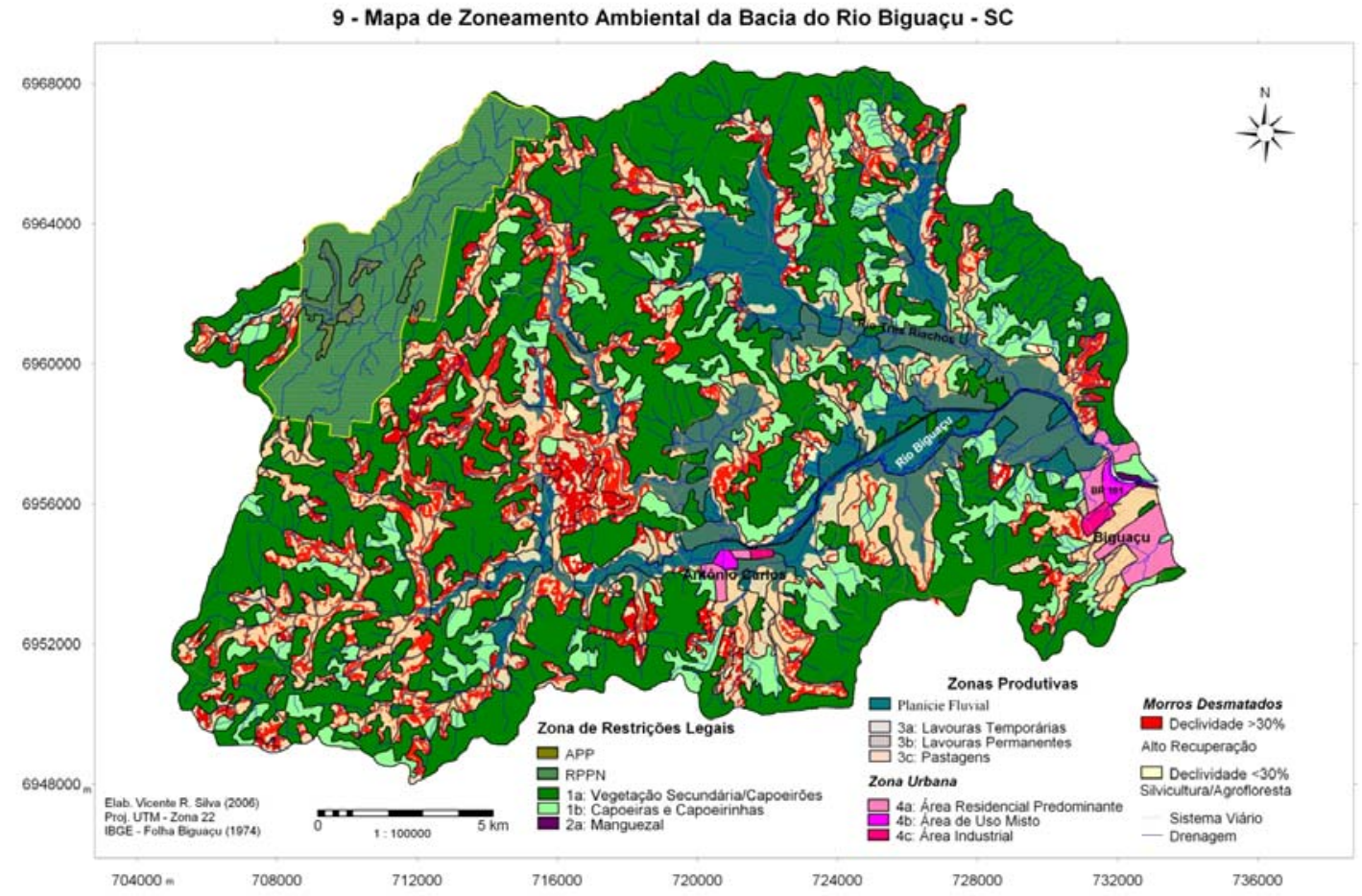

Figura 49 - Mapa de zoneamento ambiental da bacia do rio Biguaçu-SC. 


\section{0-CONSIDERAÇÕES FINAIS}

O presente estudo mostrou que a bacia hidrográfica do rio Biguaçu pode ser entendida segundo a visão sistêmica, onde processam-se as trocas de matéria e energia entre os componentes do meio físico e biótico. As atividades humanas provocam modificações na distribuição de matéria do geossistema (água e sedimentos), alterando a dinâmica natural de funcionamento do meio natural.

O processo histórico de ocupação e apropriação dos recursos naturais, deixou marcas profundas na paisagem, segundo os aspectos históricos, econômicos e políticos, conduzidos pela sociedade humana. A própria configuração dos elementos da geografia física e biológica condicionou os tipos de uso da terra na bacia do rio Biguaçu.

A pesquisa foi conduzida através da análise de informações e dados dos componentes da natureza e das inserções humanas nos municípios de Antônio Carlos e Biguaçu em Santa Catarina. Uma das etapas relevantes dessa pesquisa foi a geração de informações espaciais, que resultaram na produção de nove mapas temáticos, na escala 1: 50.000. Porém, visando adequar os mapas ao volume, os mapas foram reproduzidos na escala 1: 100.000 (tamanho de papel A-3). Os mapas foram gerados no meio digital. Os temas dos mapas foram: hipsométrico, clinográfico, geológico, unidades do relevo, solos, ocupação e uso da terra 2006, fragilidade ambiental, legislação ambiental e zoneamento ambiental.

O mapa de legislação ambiental é uma contribuição original na aplicação da base legal aplicado ao ambiente natural, com destaque à cobertura vegetal, formada basicamente por capoeirões, capoeiras, manguezal e Reserva Particular do Patrimônio Natural (RPPN) Caraguatá, no município de Antônio Carlos.

No planejamento é prevista a tomada de decisões, baseada em análise sócio-ambiental da área de estudo, para poder identificar e apresentar o melhor uso possível dos recursos naturais. O planejamento deve antever ações futuras, previsões de cenários futuros para a bacia hidrográfica. $\mathrm{O}$ ato de planejar visa atender interesses públicos, através do ordenamento das atividades humanas (Santos, 2004, p.25). Acredita-se que por meio do zoneamento ambiental proposto neste estudo, possa contribuir-se, visando disciplinar o uso da terra, com qualidade de vida para os seres humanos. 
O atual modelo econômico de agricultura e pecuária vigente na bacia tem gerado problemas ambientais. A degradação ambiental tem ocorrido em variados ambientes. Os recursos hídricos apesar da excelente disponibilidade de água em quase todas as propriedades rurais, não apresenta boa qualidade, em especial nas águas superficiais que servem às propriedades. Segundo a Epagri de Antônio Carlos (Santa Catarina, 2005b, p.7), a “apropriação da água se dá conforme ela passa pela propriedade. Não há preocupação em usála racionalmente e muito menos em controlar a sua poluição e contaminação”.

Várias ações têm sido implementadas na bacia, através de projetos da Epagri em conjunto com as prefeituras municipais de Antônio Carlos e Biguaçu, visando reverter a situação geral. Há projetos em andamento no setor de saneamento básico, fruticultura, proteção de fontes naturais de águas, no entanto, as ações são limitadas, devido pequeno volume de recursos financeiros destinados ao meio rural da bacia do rio Biguaçu.

Uma das questões cruciais da degradação ambiental do Rio Biguaçu é a ausência de sistema de coleta e tratamento de esgotos domésticos na zona urbana de Antônio Carlos e Biguaçu, onde as águas servidas são lançadas nos canais fluviais. No meio rural dos dois municípios, a água do rio Biguaçu é amplamente utilizada na irrigação da produção de hortaliças e grama, com alto risco de contaminação das verduras consumidas na região conurbada de Florianópolis. O rio Biguaçu também recebe diariamente muito lixo, apesar de haver coleta regular de resíduos sólidos pelas municipalidades. Trata-se também de uma questão de educação, de tradição e costume da falta de preocupações de um uso racional dos recursos disponíveis, sem degradá-los nas atividades humanas.

Outra preocupação dos técnicos e de ambientalistas é o custo ambiental da produção de hortaliças e grama em larga escala na região. O uso indiscriminado de agrotóxicos, contaminando os solos, água, alimentos e intoxicando as pessoas. Segundo dados da Epagri (2005), cerca de 85\% das propriedades rurais em Antônio Carlos utilizam algum tipo de veneno (herbicida, fungicida ou inseticida) (Santa Catarina, 2005b, p.12).

Observou-se neste trabalho que o método sistêmico foi adequado para realizar as análises integradas dos componentes da natureza e dos sócio-econômicos, dando uma visão integradora da organização do espaço na bacia do rio Biguaçu. Uma das limitações da utilização do método sistêmico refere-se à integração dos estudos de cada componente do 
meio ambiente, onde as ciências estão cada vez mais especializadas em seus ramos de conhecimento.

As técnicas utilizadas neste estudo foram adequadas como meio de atingir os objetivos previstos. As diferentes técnicas empregadas na cartografia digital e de imagem de satélite tiveram um bom resultado na produção dos nove mapas temáticos. Os objetivos específicos previstos foram contemplados nas análises e na produção dos mapas na escala original 1: 50.000, da bacia hidrográfica do rio Biguaçu no litoral central de Santa Catarina.

Os nove mapas elaborados representam importantes subsídios para o planejamento territorial e ambiental para Antônio Carlos e Biguaçu. Os resultados deste estudo também, contribuem para um futuro plano de recuperação ambiental e econômica da bacia do rio Biguaçu.

A presente pesquisa é uma contribuição original a nível geográfico, pois foram produzidos mapas temáticos de legislação ambiental e de zoneamento ambiental. A elaboração das diretrizes para o planejamento territorial poderá ser um instrumento útil pelo poder público estadual e municipal em seus planejamentos regional e local. A pesquisa produzida também é um referencial na elaboração dos planos diretores dos dois municípios.

Os mapas produzidos podem dar subsídios ao fórum permanente, coordenado pela Assembléia Lesgislativa de Santa Catarina, que vem discutindo, em 2007, o Gerenciamento Costeiro. O município de Biguaçu integra com mais 35 municípios o Gerco catarinense. Esses municípios terão que adequar seus planos diretores aos conceitos do Gerenciamento Costeiro, nas áreas de saneamento, recursos hídricos, ordenamento do uso de recursos naturais e na ocupação dos espaços costeiros 


\section{1-REFERÊNCIAS}

AB SABER, Aziz N. Um conceito de geomorfologia a serviço das pesquisas sobre o quaternário. In: Geomorfologia, n. 18, I. Geografia-USP, São Paulo, 1969.

ABREU, Adison Avansi de. A teoria geomorfológica e sua edificação: análise crítica.In: Revista do Instituto de Geografia, São Paulo, 4 (1/2): 5-23, jan./dez. 1983.

ACADEMIA DE CIÊNCIAS DO ESTADO DE SÃO PAULO. Glossário de Ecologia. Aciesp, n. 103, São Paulo, 1997.

ANTÔNIO CARLOS (SC). Prefeitura Municipal. Das águas, dos verdes vales e da hortaliça. Secretaria Municipal de Esporte e Turismo, 2001.

ARMUS, Haroldo Erwin. Pesquisa e a questão ambiental. In: IV Seminário Nacional sobre Universidade e Meio Ambiente. Florianópolis: UFSC-IBAMA. Anais... , 1990.

BERTALANFFY, L. V. A Teoria Geral de Sistemas. Petrópolis: Vozes, 1975.

BERTRAND, Georges. Paisagem e geografia física global - esboço metodológico. I. Geografia-USP, n. 13, Caderno de ciência da terra, São Paulo, 1971

BEROUTCHACHVILI, N.; BERTRAND, G. O Geossistema ou Sistema Territorial Natural. Trad.RIBEIRO, A. G. In: Revue Géographique des Pyrenées et du Sud-Ouest. 49 (2): 167-180. Toulouse, 1978.

BOHAM CARTER, G. F. Geographie Information Systems for geoscientists: modelling with GIS. Canada: Pergamon, 1994.

BOTELHO, Rosangela Garrido Machado. Planejamento ambiental em microbacias hidrográficas. In: Erosão e conservação dos solos. Orgs.: A. J. T. Guerra; A. S. da Silva; R. G. M. Botelho. Rio de Janeiro: Bertrand Brasil, 1999.

BUCCI, Roberto L. F.; BUCCI, Roberta B. F.; BUCCI, Eliana F. B.; BUCCI, Fernanda F. B. Legislação Ambiental. In: Boletim Goiano de Geografia, v.12, n.1, Jan./Dez., 1991.

BURROUGH, P. A. Principles of geographical information systems for land resources assessment. Oxford: Clarendon, 1986.

CAMPOS, Alexandre V. Variabilidade espaço - temporal dos parâmetros físico-químicos da zona estuarina do rio Biguaçu, SC. Trabalho de conclusão do curso de geografia. Florianópolis: UFSC, 2003.

CAPRA, Fritjof. Ponto de Mutação. São Paulo: Cultrix, 25 edição, 2005

CASSETI, Valter. Elementos de Geomorfologia. Goiânia: UFG, 1994.

CERUTTI, Rosenéa Locatelli.Contribuição ao conhecimento da poluição doméstica na baía norte, área da Grande Florianópolis. Dissertação (Mestrado em Geografia). Departamento de Geocências. Florianópolis: UFSC, 1996.

CHORLEY, R. J. \& KENNEDY, B. A. Physical Geography: A Systems Approach. London, Prentice-Hall. 1971.

CHRISTOFOLETTI, A. Aspectos da análise sistêmica em Geografia. Rio Claro -SP. Ed. Hucitec, 1978, 6(3): 1-31. 
CHRISTOFOLETTI, Antônio. Geomorfologia. São Paulo: Edgard Blucher, $2^{\mathrm{a}}$ edição, 1980. CHRISTOFOLETTI, Antônio. Modelagem de sistemas ambientais. São Paulo: Edgard Blucher, $1^{a}$ edição, 1999.

CONFEDERAÇÃO NACIONAL DE MUNICÍPIOS. Antônio Carlos -SC. Infra-estrutura abastecimento de água, esgotamento sanitário e destino do lixo. Acesso em 6 de outubro de 2006. www.cnm.org.br

COOKE, R. U. \& DOORNKAMP, J. C. Geomorphogy in environmental management Na introduction. London, Oxford, 1974.

CORRÊA, Walquíria K.; PRATES, Arlene M. M. As implicações do progresso técnico na horticultura: o caso de Antônio Carlos, SC. In: Boletim de Geografia Teorética, 25 (49-50): 327-342, 1995.

COSTA, Joaquim B. Caracterização e Constituição do Solo. Lisboa: Fundação Calouste Gulberkian, 3ª edição, 1985.

COURA NETO, Augusto B. Síntese Temática. Vegetação. Projeto Gerenciamento Costeiro (2 $2^{\mathrm{a}}$ fase). Florianópolis: IBGE, 1995.

CRÓSTA, Alvaro Penteado. Processamento digital de imagens de sensoriamento remoto. Campinas: IG/Unicamp, 1993.

CUNHA, Sandra B. Geomorfologia Fluvial. In: GUERRA, Antônio J. T.; CUNHA, Sandra B.(org) Geomorfologia: uma atualização de bases e conceitos. Rio de Janeiro: Bertrand Brasil, 3 edição, 1998.

CUNHA, Sandra B.; GUERRA, Antônio J. T. Degradação Ambiental. In: GUERRA, A. J.T.; CUNHA, S. B. (org.). Geomorfologia e Meio Ambiente. Rio de Janeiro: Bertrand Brasil, 1996.

DELPOUX, Marcel. Ecossistema e paisagem. Instituto de Geografia, USP, São Paulo: Método em questão, $n^{\circ}$ 7, 1974.

DEMEK, J. Generalization of geomorphological map. In: progress made in geomorphological mapping - Brno

ELICHER, Maria Jaqueline. Os desafios da transição agroecológica na agricultura familiar em Antônio Carlos, SC. Florianópolis: UFSC, 2002. Dissertação (Mestrado em Geografia), departamento de Geociências, Universidade Federal de Santa Catarina, 2002.

EMBRAPA. Sistema Brasileiro de Classificação de Solos. Centro nacional de Pesquisa de Solos. Brasília: Embrapa, 1 edição, 1999.

EMBRAPA. Sistema Brasileiro de Classificação de Solos (Versão Preliminar). Brasília: Embrapa, 2 edição, 2005.

FORTES, Edison. A Planície Costeira da Região de Biguaçu: Abordagens dos aspectos ambientais da bacia hidrográfica do Rio Biguaçu. Dissertação de Mestrado em Geografia. UFSC, Florianópolis, 1996.

FORTES, Edison. Delimitação e caracterização de unidades de manejo ambiental na bacia hidrográfica do rio Biguaçu-SC, Maringá, 1999(Inédito). 
FRANCO, Maria de Assunção Ribeiro. Planejamento Ambiental. São Paulo: Anablume, Fapesp, 2000.

FREYESLEBEN, L. M. C. Aspectos essenciais do rítmo climático de Florianópolis, UFSC, Tese Professor Adjunto, UFSC, 1979, 49 p.

GORTE, B. G. H.; KOOLHOVEN, W. Interpolation between isolines based on the Borgefors distance trasform. ITC Journal. ITC: Enschede, p.245-247, 1990.

GUERRA, Antônio Teixeira. Dicionário geológico-geomorfológico. Rio de Janeiro: IBGE, 1987.

GUIMARÃES, Sílvia L. G. Exploração de pedreiras para a produção de britas na região da Grande Florianópolis: aspectos sócio-econômicos e ambientais. Florianópolis: UFSC, 1996. Monografia de conclusão do curso de ciências econômicas. Universidade Federal de Santa Catarina, 1996.

HAYMUSSI, Homero. Floresta Ombrófila Mista. Seminário da disciplina Utilização e Conservação de Recursos Vegetais do Brasil. Curso de Pós-graduação em Geografia. Florianópolis: UFSC. Mimeo, 1993.(não publicado)

HENKES, Jairo A. Caracterização dos agentes do mercado atacadista na Ceasa / SC unidade de São José. Florianópolis: UFSC, 2006. Dissertação (Mestrado em Agroecossistemas). Universidade Federal de Santa Catarina, 2006.

HENRIQUE, Wendel. Zoneamento Ambiental: uma abordagem geomorfológica. Rio Claro: UNESP. Dissertação (mestrado em Geografia). Rio Claro, 2000.

HERRMANN, Maria Lúcia de P. Problemas Geoambientais da Faixa Central do Litoral Catarinense. São Paulo: USP, 1999, Tese (Doutorado em Geografia Física), Departamento de Geografia, Universidade de São Paulo, 1999.

HERRMANN, Maria Lúcia de P.; MENDONÇA, Magaly; CAMPOS, Nazareno J. São JoséSC: Avaliação das enchentes e deslizamentos ocorridos em novembro de 1991 e fevereiro de 1994. In: Geosul, n.16. Florianópolis: UFSC, ano 8: 46-78, $2^{\circ}$ sem./1993.

HERRMANN, Maria Lúcia de P.; ROSA, Rogério de O. Relevo. In: Geografia do Brasil: Região Sul. Rio de Janeiro: IBGE, v. 2, 1990.

HOFFMANN, Gilberto. Antônio Carlos - 30 anos (1963-1993). Antônio Carlos:mimeo, 1993.

HUECK, Kurt. Distribuição e habitat natural do Pinheiro-do-Paraná (Auracaria angustifolia). In: Boletim da Faculdade de Filosofia, Ciências e Letras da Universidade de São Paulo. Botânica, $n^{\circ}$ 10, p.699-722, 1953.

HUGGETT, R. J. Earth Surface Systems. New York, Springer-Verlag. 1985.

IBGE. Censo Demográfico - 1991. Resultados do Universo relativos às características da população e dos domicílios. Santa Catarina. Rio de Janeiro, n 23, 1994.

IBGE. Contagem da População - 1996. Santa Catarina. Resultados relativos à população e aos domicílios. Rio de Janeiro, v.2, 1997.

IBGE. Censo Demográfico 2000. Características da População e dos Domicílios.Resultados do Universo. Rio de Janeiro, v.1, 2001. 
IBGE. Estimativa da População Residente. Santa Catarina - 2001. Resolução n 7, de 15 de agosto de 2001. Publicado no D. O.U., n 166, de 29 de agosto de 2001.

IBGE. Estimativa da População Residente. Santa Catarina - 2002. Resolução n 4, de 21 de agosto de 2002. Publicada no D. O. U., n 168, de 30 de agosto de 2002.

IBGE. Estimativa da População Residente. Santa Catarina - 2003. Resolução n 2, de 25 de agosto de 2003. Publicada no D. O.U., n 167-A, de 30 de agosto de 2003.

IBGE. Estimativa da População Residente em 1/07/2004. Santa Catarina - 2004. Resolução n PR-7, de 23 de agosto de 2004.

IBGE. Estimativa da População Residente. Santa Catarina - 2005. Resolução n 5, de 30 de agosto de 2005. Publicada no D.O.U., n 168 de 31 de agosto de 2005.

IBGE. Estimativa da População Residente. Santa Catarina - 2006. Resolução n 2, de 28 de agosto de 2006. Publicada no D. O.U., n 168 de 31 de agosto de 2006

IBGE. Synopse do Recenseamento de 31 de dezembro de 1900. Directoria Geral de Estatistica. Ministério da Industria, Viação e Obras Publicas.Rio de Janeiro: Typographia da Estatística, 1905.

IBGE. Recenseamento de 1920. (4 Censo Geral da população e 1 da agricultura e das indústrias). Estatistica Predial e Domiciliar do Brasil. Rio de Janeiro: Typ. da Estatistica, 1930.

IBGE. Censo Demográfico de 1940 - População e Habitação. Recenseamento Geral do Brasil. Série Regional. Parte XIX - Santa Catarina. Rio de Janeiro: Serviço Gráfico do IBGE, 1951.

IBGE. Censo Demográfico. Recenseamento Geral de 1950. Serviço Nacional de Recenseamento. Série Regional, Estado de Santa Catarina. Zona do litoral de Florianópolis. Rio de Janeiro: volume XXVII, Tomo 1, 1955.

IBGE. Censo Demográfico de 1960. VII Recenseamento Geral do Brasil. Série Regional. Rio de Janeiro: volume I - Tomo XV - 1 parte, 1968.

IBGE. Censo Demográfico. VIII Recenseamento Geral - 1970. Série Regional. Rio de Janeiro, volume I - Tomo XX, 1973.

IBGE. Censo Demográfico. IX Recenseamento Geral do Brasil - 1980. Dados Distritais, Santa Catarina. Rio de Janeiro, volume 1, tomo 3, número 19, novembro de 1982.

IBGE. Enciclopédia dos Municípios Brasileiros. (Santa Catarina). Rio de Janeiro, v.32, 1959.

IBGE. Censo Agropecuário 1995-1996. Santa Catarina, número 21. Rio de Janeiro, 1997.

IBGE. Censo Agropecuário 1985. Santa Catarina, número 23. Rio de Janeiro, 1991.

IBGE. Produção Agrícola Municipal, ano 2001. Município de Antônio Carlos. Lavoura Permanente. Sidra. Acesso dia 29/03/07.

IBGE. Produção Agrícola Municipal, ano 2002. Município de Antônio Carlos. Lavoura Permanente. Sidra. Acesso dia 29/03/07. 
IBGE. Produção Agrícola Municipal, ano 2003. Município de Antônio Carlos. Lavoura Permanente. Sidra. Acesso dia 29/03/07.

IBGE. Produção Agrícola Municipal, ano 2004. Município de Antônio Carlos. Lavoura Permanente. Sidra. Acesso dia 29/03/07.

IBGE. Produção Agrícola Municipal, ano 2005. Município de Antônio Carlos. Lavoura Permanente. Sidra. Acesso dia 29/03/07.

IBGE. Produção Agrícola Municipal, ano 2001. Município de Antônio Carlos. Lavoura Temporária. Sidra. Acesso dia 18/07/05.

IBGE. Produção Agrícola Municipal, ano 2002. Município de Antônio Carlos. Lavoura Temporária. Sidra. Acesso dia 18/07/05.

IBGE. Produção Agrícola Municipal, ano 2003. Município de Antônio Carlos. Lavoura Temporária. Sidra. Acesso dia 18/07/05.

IBGE. Produção Agrícola Municipal, ano 2004. Município de Antônio Carlos. Lavoura Temporária. Sidra. Acesso dia 30/03/07.

IBGE. Produção Agrícola Municipal, ano 2005. Município de Antônio Carlos. Lavoura Temporária. Sidra. Acesso dia 30/03/07.

IBGE. Produção Pecuária Municipal, ano 2001. Município de Antônio Carlos. Sidra. Acesso dia 18/07/05.

IBGE. Produção Pecuária Municipal, ano 2002. Município de Antônio Carlos. Sidra. Acesso dia 18/07/05.

IBGE. Produção Pecuária Municipal, ano 2003. Município de Antônio Carlos. Sidra. Acesso dia 18/07/05.

IBGE. Produção Pecuária Municipal, ano 2004. Município de Antônio Carlos. Sidra. Acesso dia 30/03/07.

IBGE. Produção Pecuária Municipal, ano 2005. Município de Antônio Carlos. Sidra. Acesso dia 30/03/07.

IBGE. Produção Agrícola Municipal, ano 2001. Município de Biguaçu. Lavoura Permanente. Sidra. Acesso dia 29/03/07.

IBGE. Produção Agrícola Municipal, ano 2002. Município de Biguaçu. Lavoura Permanente. Sidra. Acesso dia 29/03/07.

IBGE. Produção Agrícola Municipal, ano 2003. Município de Biguaçu. Lavoura Permanente. Sidra. Acesso dia 29/03/07.

IBGE. Produção Agrícola Municipal, ano 2004. Município de Biguaçu. Lavoura Permanente. Sidra. Acesso dia 30/03/07.

IBGE. Produção Agrícola Municipal, ano 2005. Município de Biguaçu. Lavoura Permanente. Sidra. Acesso dia 29/03/07.

IBGE. Produção Agrícola Municipal, ano 2001. Município de Biguaçu. Lavoura Temporária. Sidra. Acesso dia 18/07/05. 
IBGE. Produção Agrícola Municipal, ano 2002. Município de Biguaçu. Lavoura Temporária. Sidra. Acesso dia 18/07/05.

IBGE. Produção Agrícola Municipal, ano 2003. Município de Biguaçu. Lavoura Temporária. Sidra. Acesso dia 18/07/05.

IBGE. Produção Agrícola Municipal, ano 2004. Município de Biguaçu. Lavoura Temporária. Sidra. Acesso dia 30/03/07.

IBGE. Produção Agrícola Municipal, ano 2005. Município de Biguaçu. Lavoura Temporária. Sidra. Acesso dia 30/03/07.

IBGE. Produção Pecuária Municipal, ano 2001. Município de Biguaçu. Sidra. Acesso dia 18/07/05.

IBGE. Produção Pecuária Municipal, ano 2002. Município de Biguaçu. Sidra. Acesso dia 18/07/05.

IBGE. Produção Pecuária Municipal, ano 2003. Município de Biguaçu. Sidra. Acesso dia 18/07/05.

IBGE. Produção Pecuária Municipal, ano 2004. Município de Biguaçu. Sidra. Acesso dia 30/03/07.

IBGE. Produção Pecuária Municipal, ano 2005. Município de Biguaçu. Sidra. Acesso dia 30/03/07.

JATOBÁ, Lucivânio; LINS, Raquel Caldas. Introdução a geomorfologia 1, Recife: Bagaço, 1995.

JORNAL. Ecologista pede projeto de revitalização do rio Biguaçu. Jornal Biguaçu em Foco, Biguaçu, 6 mar. 2007, p.6.

JUSTUS, Jarbas de O. Hidrografia. Geografia do Brasil: Região Sul. Rio de Janeiro: IBGE, v.2, 1990.

KAUL, Pedro F. T. Geologia. In: Geografia do Brasil: Região Sul. Rio de Janeiro: IBGE, v. 2, 1990.

KAUL, Pedro F. T.; FERNANDES, Edgard; SANTOS NETO, Adelino. Geologia. In: Projeto de Gerenciamento Costeiro ( $3^{\text {a }}$ fase). Relatório Técnico. Florianópolis: IBGE, 2003.

KLEIN, R. M. Mapa fitogeográfico do Estado de Santa Catarina. UFSC / Herbário Barbosa Rodrigues, Itajaí, 1978.

KLIMASZEWSKI, Meczyslam. Mapa geomorfológico de detalhe. Academia de ciências, Krakovia, Polônia. IJC Journal, p. 265-271, 1982.

KREMER, Rogério. Datas Históricas de Antônio Carlos: 1830 - 1992. Florianópolis: PapaLivro, 1993.

KUERTEN, Roberto M. Síntese Temática. Uso e Cobertura Atual do Solo. Projeto Gerenciamento Costeiro ( $2^{\text {a }}$ fase). Florianópolis:IBGE, 1995

LAGO, Paulo F. Enchentes em Santa Catarina - Quando um fenômeno vira rotina. In:

Ciência Hoje, Rio de Janeiro, v.8, n.43: 52-58, junho de 1988. 
LAGO, Paulo F. Enchentes-Erosão-Vegetação. In: $2^{\circ}$ Encontro Nacional de Estudos sobre Meio Ambiente. Florianópolis. Conferências e Painéis. Anais, v. 3, Florianópolis: UFSC, p.258-266, 1989

LEITE, Pedro F.; KLEIN, Roberto M. Vegetação. In: Geografia do Brasil, Região Sul. Rio de Janeiro: IBGE, v.2, 1990.

LEITE, Pedro F. Cobertura e Uso do Solo. Projeto de Gerenciamento Costeiro-Gerco (3 ${ }^{\text {a }}$ fase). Florianópolis: IBGE, 2003.

LEPSCH, Igo F. Solos - Formação e Conservação. São Paulo: Melhoramentos. Série Prisma Brasil, $4^{\text {a }}$ edição, 1982.

LUIZ, Edna L.; WILVERT, S. R. Modificações antrópicas no relevo da cidade de Antônio Carlos / SC. In: VI Simpósio Nacional de Geomorfologia, Resumos, Anais, v. II, C-Rom, UFG: Goiânia, 2006.

MAIO, Celeste Rodrigues. Indicadores geomorfológicos no estudo do meio ambiente. In: Geografia, 8 (15-16): 181-183, Rio Claro, out./,1983.

MAXIMIANO, Liz A. Considerações sobre o conceito de paisagem. In: RA'EGA: o espaço geográfico em análise. Curitiba: UFPR, departamento de geografia, v.8, ano 8:83-91, 2004.

MENDONÇA, Magaly. A dinâmica têmporo-espacial do clima subtropical na região conurbada de Florianópolis/SC. São Paulo. 2002, Tese de Doutorado (Programa de PósGraduação em Geografia Física) - Departamento de Geografia, FFLCH, Universidade de São Paulo, 2002.

MENDONÇA, Magaly. $O$ clima subtropical úmido na região conurbada de Florianópolis. In: VI Simpósio Brasileiro de Climatologia Geográfica -Diversidade Climáticas. Aracaju: UFS, CD-Rom, v.1 , 2004.

MINISTÉRIO DO MEIO AMBIENTE. Zoneamento Ecológico-Econômico do Baixo Rio Parnaíba: Subsídios Técnicos. Relatório Final. Brasília, 2002.

MONTEIRO, Carlos Augusto de F. Geossistemas a história de uma procura. São Paulo: Contexto, 3 geousp novas abordagens, 2000.

MONTEIRO, Maurici A.; FURTADO, Sandra M. de A. O clima do trecho Florianópolis Porto Alegre. Geosul, nº 19/20, p.117-133, 1995.

MONTEIRO, Maurici A. Avaliação das condições atmosféricas de Florianópois para controle da qualidade do ar. Monografia (Graduação em Geografia). Departamento de Geociências. Florianópolis: UFSC, 1992.

MONTEIRO, Gisele K. Terra a vista além da capital. Diário Catarinense. Florianópolis, 28 set. 2003, Caderno Santa catarina, p.31-34.

MOROZ, Isabel C.; KANIL, Kátia; ROSS, Jurandyr L. S. Problemas ambientais nas áreas de proteção aos manancias da região metropolitana de São Paulo. In: Revista do departamento de geografia, São Paulo, nº 7, p.35-48, 1994.

MOSER, José M. Solos. In: Geografia do Brasil: Região Sul. Rio de Janeiro: IBGE, v. 2, 1990. 
MOURA E SILVA, Mônica. Técnicas cartográficas aplicadas ao zoneamento ambiental: município de Jacareí - SP. Dissertação (Curso de Pós-Graduação em Geociências). Rio Claro: UNRSP, 2002.

NEIS, Ágnes. Análise Comparativa (1956 - 1995), uso do solo sub-bacia do rio Rachadel, Antônio Carlos - S.C. Relatório de Estágio. Curso de Geografia, departamento de Geociências, Florianópolis: UFSC, 1997.

NIMER, Edmon. Clima. In: Geografia do Brasil: Região Sul. Rio de Janeiro: IBGE, v.2, 1990.

OLIVEIRA, Cêurio. Dicionário Cartográfico. Rio de Janeiro: IBGE, 1983.

OLIVEIRA, Fabiano A. de. Estudo do aporte sedimentar em suspensão na baía de Babitonga sob a ótica da geomorfologia. Tese (Doutorado em Geografia Física). Departamento de Geografia. Faculdade de Filosofia, Letras e Ciências Humanas da USP, 2007.

OLIVEIRA, Marcelo A. T. de: HERRMANN, Maria Lúcia de P. Ocupação do solo e riscos ambientais na área conurbada de Florianópolis. In: Inpactos Ambientis Urbanos no Brasil. GUERRA, Antônio J. T.; CUNHA, Sandra B. da (org.), Rio de Janeiro: Bertrand Brasil, 2001.

ORSELLI, Leda Climatologia. In: Atlas de Santa Catarina. Gaplan. Rio de Janeiro: Aerofoto Cruzeiro, p.38-39, 1986.

PAIVA, Doralice P. Manuntenção e recuperação de faixas ciliares de cursos d'água e nascentes. In: Tecnologias para o manejo de resíduos na produção de suínos: manual de boas práticas. Oliveira, Paulo A.V. de (coord.). Concórdia: Embrapa Suínos e Aves, 2004.

PANITZ, Clarice M. N.; PORTO FILHO, Érico. O Manguezal do rio Caveiras, Biguaçu, SC - Um estudo de caso: I - a ação civil pública como instrumento jurídico para a preservação, conservação e manejo do ecossistema.In: Geosul, Florianópolis, ano 8, n.15: 89-98, $1^{\circ}$ semestre de 1993.

PASSOS, Messias Modesto dos. Biogeografia e Paisagem. Programa de Pós-graduação em Geografia- FCT, UNESP- Presidente Prudente e Programa de Pós-graduação em Geografia UEM, Maringá Ed. do autor, 1988.

PASSOS, Messias Modesto dos. Geossistema: um novo paradigma? In: VII Simpósio Brasileiro de Geografia Física Aplicada. Anais ... São Paulo: Tec art, p. 42, 1997.

PAULI, Estella. Estrutura da Secretaria de Turismo da Prefeitura Municipal de Antônio Carlos. Trabalho de conclusão de curso em adminstração. Centro de Educação Superior IV. Biguaçu: Univali, 2001.

PENTEADO, Margarida M. Fundamentos de Geomorfologia. Rio de Janeiro: IBGE, $3^{\text {a }}$ edição, 1983

PIRES, Joni de L.; COITINHO, João Batista L.; FREIRE, Francisco de A.; FERNANDES, Edgard. Geologia. Síntese Temática. In: Estudos Ambientais da Grande Florianópolis. Florianópolis: IBGE/ IPUF, 1997. 
PIRES, Joni de Lima. O Planejamento das atividades de mineração para a área conurbada de Florianópolis. Florianópolis: UFSC, 2000. Dissertação (Pós-Graduação em Engenharia Civil), Florianópolis, Universidade Federal de Santa Catarina, 2000.

PORTO FILHO, Érico. O Manguezal do rio Caveiras, Biguaçu, SC - Um estudo de caso II A geomorfologia e o manejo do ecossistema costeiro. In: Geosul, Florianópolis, ano 9, n.17: 62-72, $1^{\circ}$ semestre de 1994.

PRATES, Arlene M. M.; CORRÊA, Walquíria K. Extensão Rural, Estrutura Agrária e Uso da Terra no município de Antônio Carlos - SC. In: Geosul: Florianópolis, n.8:30-47, 1989.

PREFEITURA MUNICIPAL DE ANTÔNIO CARLOS. Antônio Carlos: Das águas, dos verdes vales e da hortaliça. Folders. Secretaria municipal de Esporte e Turismo, 2001.

PREFEITURA MUNICIPAL DE BIGUAÇU. Obras do projeto Beira-Rio iniciam na foz do rio. Disponível em: <http:// www.bigua.sc.gov.br. > Acesso em 06 out. 2006.

REITZ, Raulino Alto-Biguaçu: Narrativa Cultural Tetrarracial. Florianópolis: Lunardelli / UFSC, 1988.

RIZZINI, Carlos Toledo. Tratado de Fitogeografia do Brasil. São Paulo: Hucite / Edusp, v.2, 1979.

ROMARIZ, Dora do Amarante. Aspectos da Vegetação do Brasil. São Paulo: Edição da Autora, 2ª edição, 1996.

ROSA, Rogério de O. Projeto de Gerenciamento Costeiro (2 fase). Síntese Temática. Geomorfologia. Florianópolis: IBGE, 1995.

ROSS, Jurandyr L. S. Análises e sínteses na abordagem geográfica da pesquisa para o planejamento ambiental. In: Revista do departamento de geografia, $n^{\circ}$ 8, FFLCH-USP, 1991.

ROSS, Jurandyr L. S. Análise empírica da fragilidade dos ambientes naturais e antropizados. In: Revista do departamento de geografia, São Paulo, nº 8, FFLCH, USP, 1994.

ROSS, Jurandyr L. S. Geomorfologia - ambiente e planejamento. São Paulo: Contexto, 2000

ROSS, Jurandyr L. S. Geomorfologia Ambiental. In: Geomorfologia do Brasil. Rio de Janeiro: Bertrand Brasil, 1998.

ROSS, Jurandyr L. S. ; DEL PRETTE, Marcos E. Recursos hídricos e as bacias hidrográficas: âncoras do planejamento e gestão ambiental. In: Revista do departamento de geografia, São Paulo (12), p.89-121, 1998.

ROSS, Jurandyr L. S. A morfogênese da bacia do ribeira do iguape e os sistemas ambientais. In: Geousp, Espaço e Tempo, São Paulo, nº 12, 2002.

ROSS, Jurandyr L. S. Cartografia Geomorfológica. In: Mesa Redonda no V Simpósio Brasileiro de Geomorfologia, Santa Maria, UFSM, 2004.

ROSS, Jurandyr L. S. O registro cartográfico dos fatos geomórficos e a questão da taxonomia do relevo.In: Revista dep. Geografia, n. 6, FFLCH-USP, São Paulo, 1992.

ROSS, Jurandyr L. S. Ecogeografia do Brasil: Subsídios para o Planejamento Ambiental. São Paulo: Oficina de Textos, 2006. 
SANTA CATARINA. Bacias Hidrográficas do Estado de Santa Catarina: Diagnóstico Geral. Secretaria de Estado do Desenvolvimento Urbano e Meio Ambiente -SDM, Florianópolis, 1997.

SANTA CATARINA. Programa Integrado de Desenvolvimento Sócio-Econômico-Novas Oportunidades - Antônio Carlos - SC. Florianópolis, 1990, 30 p.(a)

SANTA CATARINA. Programa Integrado de Desenvolvimento Sócio-Econômico- Novas Oportunidades - Biguaçu - SC. Florianópolis, 1990, 27 p.(b)

SANTA CATARINA. Levantamento Agropecuário de Santa Catarina. Dados Preliminares, fevereiro/2005. Secretaria de Estado da Agricultura e Desenvolvimento Rural. Florianópolis, v.1, CD-ROM, 2005.(a)

SANTA CATARINA. Plano Municipal de Desenvolvimento Rural Sustentável 2005/2008. Município de Antônio Carlos. Antônio Carlos, 2005.(b)

SANTA CATARINA. Plano Municipal de Desenvolvimento Rural e Pesqueiro -2005/ 2008. Município de Biguaçu. Biguaçu, 2005.(c)

SANTA CATARINA. Dados de clima da Estação Climatológica Principal de São José. Empresa de Pesquisa Agropecuária e Extensão rural de Santa Catarina (EPAGRI). Período de janeiro de 1998 a dezembro de 2005. Florianópolis, 2006.

SANTA CATARINA. Dados de clima da Estação Climatológica Principal de São José. EPAGRI. Período de de janeiro de 1911 a dezembro de 1997. Florianópolis, 1998.

SANTOS, Rozely Ferreira dos. Planejamento Ambiental teoria e prática. São Paulo: Oficina de Textos, 2004.

SAUER, Carl The morphology of landscape. University of California, Publication in geography, 2, p. 19-53, 1925.

SANTOS, Irani dos et ali. Hidrometria Aplicada. Curitiba: Instituto de Tecnologia para o Desenvolvimento, 2001.

SCHIER, Raul A. Trajetórias do conceito de paisagem na geografia. In: RA'E GA: Curitiba, n.7, p.79-85, 2003.

SEBEN, Cristhiane. A dimensão do rural: reflexão crítica sobre a delimitação administrativa ilustrada pela análise de quatro municípios catarinense. Florianópolis: UFSC, 2001. Dissertação (Mestrado em Agrossistemas). Universidade Federal de Santa Catarina, 2001.

SHIMIZU, Sérgio H.; VIEIRA, Paulo César; MOSER, José Marcos. Solos. Projeto de Gerenciamento Costeiro - Gerco (3 ${ }^{\mathrm{a}}$ fase). Florianópolis: IBGE, 2003.

SILVA, Jorge X. da. Unidades de manejo ambiental: a contribuição geomorfológica. III Encontro Nacional de Geógrafos, AGB, Fortaleza, Anais... Fortaleza: 19-27 de jul.,p. 103104, 1978.

SILVA, Teresa Cardoso da. Cartografia geomorfológica. In: Mesa Redonda no V Simpósio Brasileiro de Geomorfologia, UFSM, Santa Maria, 2004. 
SILVA, Vicente R. Condicionantes históricos e ambientais do uso do rio Biguaçu em Antônio Carlos e Biguaçu - SC. In: XI Simpósio Brasileiro de Geografia Física Aplicada. Anais, São Paulo: USP, 2005, v.1, p.4134-4143, CD-Rom.

SILVA, Vicente R.; ROSS, Jurandyr L. S. Geomorfologia da bacia do rio Biguaçu no litoral central de Santa Catarina. In: VI Simpósio Nacional de Geomorfologia, Anais, v. II, Trabalhos Completos, CD-Rom. UFG: Goiânia, 2006.

SILVA, Vicente R. Aspectos históricos, estrutura agrária e uso da terra na bacia do rio Biguaçu em Santa Catarina. In: III Seminário de Pesquisa em Geografia Física. Anais, São Paulo: FFLCH-USP, v.1, CD-Rom, p.444-454, 2006.

SOARES, Iaponan. História do Município de Biguaçu. Florianópolis: AAA-SC, 1988.

SOTCHAVA, V. B. O estudo de Geossistema. Métodos em Questão, São Paulo, 1977, 16:1-52

SOTCHAVA, V. B. Por uma teoria de classificação de geossistemas da vida terrestre. Instituto de Geografia. In: Biogeografia, nº 14, São Paulo, 1978.

SOUZA, Bernardo Sayão Penna e. A qualidade da água de Santa Maria/RS: uma análise ambiental das subbacias hidrográficas dos rio Ibicuí Mirim e Vacacaí Mirim. Tese de doutorado, FFLCH-USP, Departamento de Geografia, São Paulo, 2001.

SOUZA, Édna Regina. Favelas Prado e Saveiro: um retrato da segregação espacial em Biguaçu. Monografia de Conclusão do Curso de Ciências Econômicas. Florianópolis: UFSC, 1997.

STRAHLER, A. N. Systems theory in physical geography. Phys. Geog.,1(1): 1-27, 1980

TERJUNG, W. B. Climatology for geographer. Ann. Assoc. Am. Geog., 66: 199-222, 1976

TOMLIN, C. D. Geographie information systems and cartographie modelling. New Jersey: Prentice Hall, 1990.

TRAININI, Douglas R. Projeto Vidal Ramos-Biguaçu. Companhia de Pesquisa e Recursos Minerais. Porto Alegre, v. 1, 1978.

TRICART, Jean. Ecodinâmica. Rio de Janeiro: IBGE-SUPREN, 1977.

TRICART, J. A Geomorfologia nos Estudos Integrados de Ordenação do Meio Natural. Boletim Geográfico. Rio de Janeiro: IBGE, 34 (251): 15-42, 1976.

TRICART, J. Observation des phenomenes at des faits geomorfologiques. In: Principes et methodes de la geomorphologie. Masson et cie editemas, Paris, 1965.

TROPPMAIR, H. Ecossistemas e Geossistemas do estado de São Paulo. Biogeografia, São Paulo, 1981, 18: 1-10.

TROPPMAIR, Helmut. Importância de cartas geomorfológicas em estudos ambientais. Rio Claro: Geografia, 5 (9-10): 97-102, out./, 1980.

VALENTE, Osvaldo F.; GOMES, Marcos Antônio. Conservação de Nascentes. Hidrologia e Manejo de Bacias Hidrográficas de Cabeceiras. Viçosa: Aprenda Fácil, 2005. 
VEADO, Ricardo W. ad-Víncula. Geossistemas de Santa Catarina. Rio Claro: UNESP, 1999. Tese (Organização do Espaço). Departamento de Geografia, Universidade Estadual Paulista, 1999.

VELOSO, Henrique P.; RANGEL FILHO, Antônio L.: LIMA, Jorge Carlos A. Classificação da Vegetação Brasileira, adaptada a um sistema universal. Rio de Janeiro: IBGE, 1991.

VIEIRA, Lúcio S. Manual da Ciência do Solo: ênfase aos solos tropicais. São Paulo:Agronômica Ceres, 1988.

VITTE, Antônio Carlos; GUERRA, Antônio José T. (Org.) Reflexões sobre a Geografia Física no Brasil. Rio de Janeiro: Bertrand Brasil, 2004.

ZONNEVELD, I. S. The land unit. A fundamental concept in landscape ecology and its application. In: Landscape Ecology, Academia Publishing, Holanda, col. 3, n. 2, p.67-86, 1989. 